UNIVERSIDADE DE SÃO PAULO

FACULDADE DE FILOSOFIA, LETRAS E CIÊNCIAS HUMANAS

PROGRAMA DE PÓS-GRADUAÇÃO EM CIÊNCIA POLÍTICA

Christian Jecov Schallenmüller

O discurso da "conciliação nacional" e a justiça de transição no Brasil 
Christian Jecov Schallenmüller

\title{
O discurso da "conciliação nacional e a justiça de transição no Brasil
}

\begin{abstract}
Tese apresentada ao Programa de PósGraduação em Ciência Política da Faculdade de Filosofia, Letras e Ciências Humanas da Universidade de São Paulo como requisito parcial para obtenção do título de Doutor em Ciência Política.
\end{abstract}

Orientador: Prof. Dr. Bernardo Ricupero.

São Paulo 


\section{FOLHA DE APROVAÇÃO}

Nome: Christian Jecov Schallenmüller

Título: O discurso da "conciliação nacional" e a justiça de transição no Brasil

Tese apresentada ao Departamento de Ciência Política da Faculdade de Filosofia, Letras e Ciências Humanas da Universidade de São Paulo como requisito parcial para a obtenção de título de Doutor em Ciência Política.

Aprovada em:

Banca examinadora:

Professor(a) Dr(a): :

Instituição:

Julgamento:

Assinatura:

Professor(a) Dr(a).

Instituição:

Julgamento:

Assinatura:

Professor(a) Dr(a).

Instituição:

Julgamento:

Assinatura: 
Professor(a) Dr(a).

Instituição:

Julgamento:

Assinatura:

Professor(a) Dr(a).

Instituição:

Julgamento:

Assinatura: 
Dedico este trabalho a todos aqueles que lutaram e lutam contra o autoritarismo. 


\section{Agradecimentos}

A finalização da tese é em alguma medida também o fechamento de uma das etapas mais importantes da formação acadêmica. Neste processo, que extrapola a própria tese, muitas pessoas foram importantes, mas nomeá-las todas aqui seria muito prolixo. Por isso, resolvi deixar meu reconhecimento àqueles que mais propriamente estiveram envolvidos, em formas, níveis e etapas diferentes, com o desenvolvimento da tese. Com relação à minha formação em geral, resolvi mencionar apenas aqueles que considero terem sido os maiores responsáveis por algumas de minhas escolhas acadêmicas. Por último, mas não menos importante, amigos e familiares.

Em primeiro lugar e de modo muito especial, agradeço a meu orientador Bernardo Ricupero, que em sua concepção abrangente sobre a pesquisa e o trabalho acadêmico em Ciência Política sempre me apoiou fortemente em meus empreendimentos pouco convencionais. Leitor tão atento e crítico quanto generoso, sua orientação foi de fundamental importância para o aperfeiçoamento da tese. Agradeço também a Gildo Marçal Brandão (em memória), meu primeiro orientador e que certamente em muitos aspectos continuou inspirando algo da proposta desta tese. E a Airton Andrade Leite, cujos conselhos e generosidade também foram fundamentais na trajetória de meus primeiros passos e nas minhas primeiras escolhas acadêmicas.

Agradeço aos professores Rainer Schmidt, Patrício Tierno e Eunice Ostrensky, com os quais aprendi muito e tive a oportunidade de desenvolver algumas atividades durante o doutorado. Aos professores Cícero Romão de Araújo e Edson Teles, pela leitura atenta e crítica que fizeram na qualificação, o que também sem dúvida ajudou-me a fazer um recorte mais preciso e a aperfeiçoar a narrativa da tese. A postura de engajamento político e de pesquisa crítica de Edson Teles é certamente motivo de inspiração para mim. Agradeço ainda ao professor Andrew Arato e à New School for Social Research, que me acolheram no doutorado-sanduíche, experiência que foi indispensável para que eu conseguisse maior profundidade analítica no texto. Raphael Neves, cujo empenho foi fundamental para a viabilidade de meu doutorado-sanduíche, e Renan Quinalha, que me ajudou na ponte com algumas entrevistas, também foram dois dos mais importantes interlocutores que tive para a tese e para o tema da justiça de transição. À Glenda Mezarobba e à Isabel Ricupero, agradeço também pelas leituras críticas e detalhadas que fizeram, a primeira de minha versão inicial de projeto de doutorado, a segunda do capítulo 1 da tese. Da mesma forma a(o) parecerista da FAPESP, cujas críticas e sugestões em momentos diferentes da pesquisa me ajudaram a dar maior densidade e rigor ao texto. Boa parte dos méritos que venha a ter este trabalho deve a muitas destas pessoas; os erros remanescentes são de minha inteira responsabilidade.

Por valorizarem minha pesquisa, sou grato à FAPESP e ao programa CAPES/Fulbright, cujos financiamentos propiciaram a realização de um trabalho com dedicação integral no Brasil e no exterior.

Agradeço ao professor Fábio Konder Comparato, a Paulo Abrão, Marcelo Torelly e Amelinha Teles pela disponibilidade que tiveram em me fornecer materiais e conversar a 
respeito do tema, apesar de suas agendas atarefadas. Com relação às entrevistas que consegui realizar, agradeço ainda aos amigos Felipe de Paula e Heloisa Estellita, sem os quais boa parte delas não teria acontecido.

Sou especialmente grato aos funcionários das secretarias do DCP e da CPG, que sempre me ajudaram muito a vencer os empecilhos burocráticos e a tornar o ambiente de trabalho mais agradável (particularmente Rai, Márcia, Vasne, Léo, Regina e Aline).

Agradeço aos meus amigos do DCP e que fiz em NY, com os quais aprendi muito e cuja companhia foi sempre um alento durante estes anos de formação puxada. Faço uma menção em particular aqui à Thais por me ajudar a "encontrar" (entre aspas porque eu não a procurava) uma das epígrafes da tese.

Agradeço especialmente ainda à Márcia (que, família e amiga, é também responsável por me ajudar a recuperar a saúde durante o doutorado). Meus pais, que sempre apoiaram meus empreendimentos em todos os sentidos, minha irmã e a turma do camping são, ao lado de minha esposa, os responsáveis por toda a retaguarda emocional. O contato com estas pessoas sempre foi indispensável para minha formação que extrapola a questão acadêmica. Por tudo isso, sou muito grato a eles. Além de ser a minha companheira e confidente, a Mari também me ajudou muito nesta tese, desde me estimular a perseguir o tema e discuti-lo em várias ocasiões, passando por "encontrar" a primeira epígrafe, formatação da bibliografia e revisão do texto. 
Porém, nossa república não foi constituída pelo engenho de um, mas de muitos, nem durante a vida de um homem, mas em alguns séculos e gerações. Pois [Catão] dizia jamais ter existido um engenho tão grande - alguém a quem nada escapasse e que nem todos os engenhos reunidos em um só poderiam prever tanto, [a ponto de] abarcar em apenas um momento tudo, sem a experiência das coisas e sem amadurecimento.

Marco Túlio Cícero, De Republica, livro II, $2 .^{1}$

Tampouco conheço pacto tão sagrado que me impeça de exigir justiça.

John Milton, A tenência de reis e magistrados, p. 41

\footnotetext{
${ }^{1}$ A citação acima foi retirada de Bernardo (2013, p. 122), dissertação que realiza nova tradução da obra De República de Cícero.
} 


\section{RESUMO}

A pesquisa tem dois objetivos centrais: reconstruir o desenvolvimento da justiça de transição no Brasil até os dias atuais e identificar algumas das principais razões dos limites de sua implementação no país. Conforme as principais hipóteses, os limites da experiência da justiça transicional no Brasil estão associados a um discurso sobre a redemocratização no país, discurso este que tem a "conciliação nacional" como sua principal categoria.

A primeira hipótese da pesquisa é a de que o discurso da "conciliação nacional", veiculado pelo menos desde a elaboração do projeto de anistia pelo governo Figueiredo, continuaria a ser um dos principais limites ao desenvolvimento da justiça de transição no Brasil. Mas a segunda hipótese sustenta que, dos últimos trabalhos mais aprofundados sobre o tema para cá, este discurso teria sua hegemonia contestada de forma significativa, sendo obrigado a ceder a algumas das demandas de entidades da sociedade civil que até pouco tempo atrás não eram consideradas como negociáveis. Os objetivos e hipóteses centrais da tese serão mobilizados na seguinte estrutura. Capítulo 1: teoria e crítica dos parâmetros normativos da justiça de transição. Capítulo 2: reconstituição histórica e discursiva sobre a anistia e sobre o programa brasileiro de reparações. Capítulo 3: reconstituição discursiva e crítica sobre o julgamento do STF acerca da constitucionalidade da bilateralidade da anistia e sobre o estágio das ações penais movidas pelo Ministério Público Federal. Capítulo 4: reconstituição crítica dos trabalhos da Comissão Nacional da Verdade.

Palavras-chave: Justiça de Transição; Anistia; conciliação nacional. 


\begin{abstract}
The research has two main objectives: to reconstruct the development of transitional justice in Brazil until today and to identify some of the main reasons underlying the limits of its implementation in the country. According to our main hypotheses, the limits of transitional justice in Brazil are associated with a discourse on the country's democratization, which holds "national reconciliation" as its crucial category.

The hypothesis 1 of the research asserts that the discourse of "national reconciliation", elaborated at least since the project of amnesty by the Figueiredo government, remains one of the main limitations to the development of transitional justice in Brazil. But the hypothesis 2 maintains that from the last major works on the subject to today, the hegemony of this discourse has been significantly challenged, giving some room to historical claims of civil society that until recently were not considered negotiable. The objectives and main hypotheses will be developed in the following structure. Chapter 1: theory and critique of the normative parameters of transitional justice. Chapter 2: historical and discursive reconstitution of the amnesty and of the Brazilian program of reparation. Chapter 3: discursive reconstitution and critique of the decision of the Brazilian Supreme Court on the amnesty's constitutionality and the stage of criminal cases filed by federal prosecutors. Chapter 4: critical reconstitution of the work of the National Truth Commission.
\end{abstract}

Keywords: Transitional Justice; Amnesty; national reconciliation. 


\section{Índice}

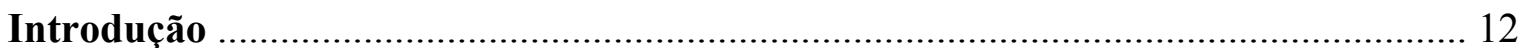

Capítulo 1. Justiça de transição: teoria e prática .................................................................. 24

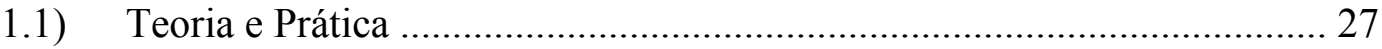

1.2) Evolução do campo nas últimas décadas ................................................. 41

1.2.1) Justiça ................................................................................... 41

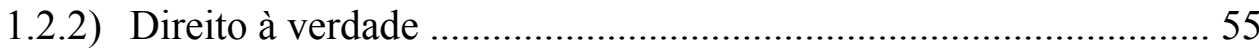

1.2.3) Anistias, reparações e reconciliação ............................................. 68

1.2.4) A jurisprudência da Corte Interamericana de Direitos Humanos . 76

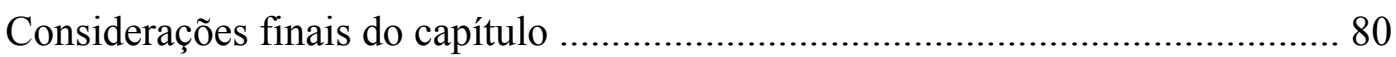

Capítulo 2. A anistia e o programa brasileiro de reparações ............................................ 84

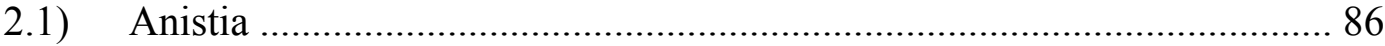

2.1.1) Origens sociais da luta por anistia e o projeto governista ............ 86

2.1.2) O discurso sobre o papel da anistia na transição democrática ...... 92

2.2) O programa brasileiro de reparações ...................................................... 100

2.2.1) A Comissão Especial sobre Mortos e Desaparecidos Políticos .. 101

2.2.2) A Comissão Nacional de Anistia ................................................. 110

Considerações finais do capítulo ...................................................................... 121

Capítulo 3. A jurisprudência de Tribunais brasileiros na esfera penal .......................... 126

3.1) A ADPF 153 e as Extradições 974, 1.150 e 1.278................................... 128

3.1.1) As Extradições 974, 1.150 e 1.278 ............................................. 129

3.1.2) As manifestações da AGU, da PGR e dos amici curiae na ADPF 153 131

3.1.3) O voto do relator da ADPF 153 .............................................. 134

3.1.4) Os votos divergentes ......................................................... 138

3.1.5) Os votos que acompanharam o relator ..................................... 140

3.1.6) A ADPF 153 e a "ideologia secundária" .................................... 145

3.2) O julgamento da Corte Interamericana, as ações penais promovidas pelo MPF e outras possibilidades do avanço do mecanismo "justiça" ........... 148

3.2.1) A Corte Interamericana e o caso Guerrilha do Araguaia ............ 148 
3.2.2) Ações penais ajuizadas pelo MPF e as variadas reações da Justiça Federal 153

3.2.3) O parecer da PGR na ADPF 320, os projetos de lei pela revogação da bilateralidade da anistia e os novos ministros do STF 162

Considerações finais do capítulo 167

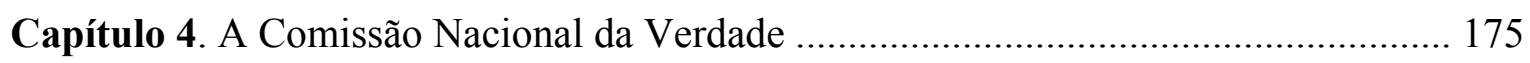

4.1) Do PNDH-3 ao funcionamento da CNV ............................................. 177

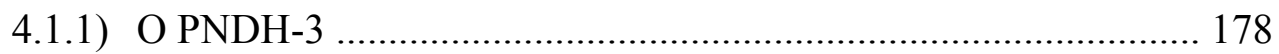

4.1.2) As Leis 12.527/2011 e 12.528/2011 e a instalação da CNV ....... 181

4.1.3) As atividades da CNV e a interação com a sociedade civil ........ 185

4.2) O relatório final da CNV e sua repercussão .......................................... 196

4.2.1) Estrutura do relatório final ...................................................... 197

4.2.2) Repercussão do relatório final ................................................. 204

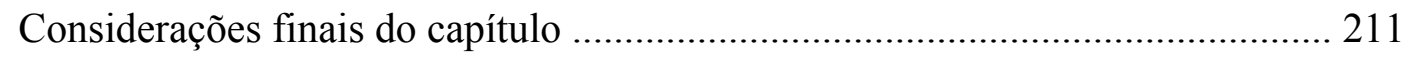

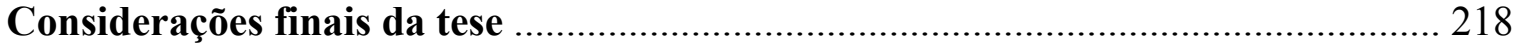

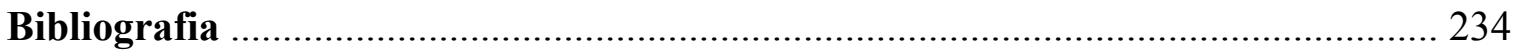

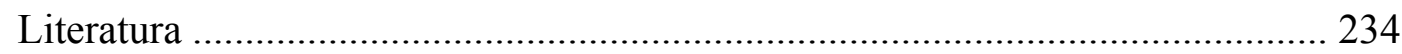

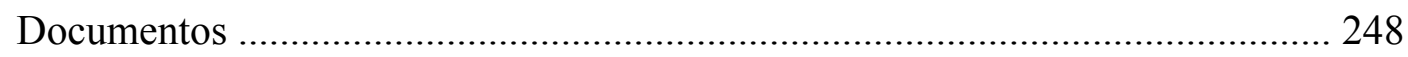

Comissão Especial sobre Mortos e Desaparecidos Políticos .................. 248

Comissão Nacional de Anistia ................................................................. 248

Comissão Nacional da Verdade ............................................................ 249

Supremo Tribunal Federal .................................................................. 250

Ministério Público Federal e Advocacia Geral da União ........................ 252

Congresso Nacional e Presidência da República ................................... 253

Corte Interamericana de Direitos Humanos ............................................ 254

Organização das Nações Unidas (ONU) ............................................... 255

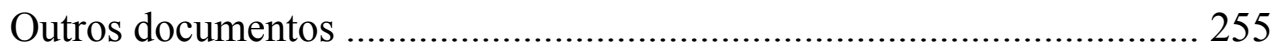

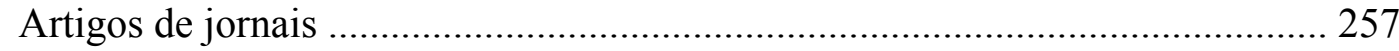

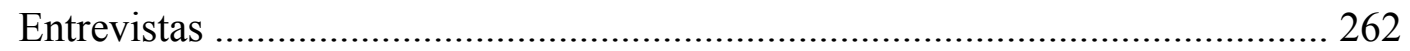

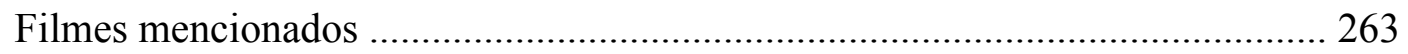




\section{INTRODUÇÃO}

A justiça de transição é um campo da teoria política que se insere no contexto de internacionalização do direito e da relativização da soberania dos Estados Nacionais para a proteção dos direitos humanos. Dito de forma resumida, em seu sentido tradicional, a justiça de transição é um conjunto de mecanismos judiciais e extrajudiciais que têm por objetivo, em tempos de transição entre regimes e mesmo depois, estabelecer um processo de acerto de contas com um passado de autoritarismo e violência em massa em diferentes Estados.

Nas últimas décadas, os trabalhos teóricos sobre o tema se adensaram, bem como a jurisprudência, sobretudo de Tribunais internacionais. Com a sedimentação destes trabalhos nos últimos anos, foi possível à literatura especializada sistematizar um conjunto básico de quatro obrigações ${ }^{2}:$ 1) a reforma das instituições políticas ${ }^{3}$; 2) a afirmação do direito à verdade e à memória ${ }^{4}$; 3 ) o julgamento e a condenação de pessoas envolvidas em graves violações aos direitos humanos ${ }^{5}$; e 4) a reparação material e simbólica das vítimas da repressão política. ${ }^{6}$

\footnotetext{
${ }^{2}$ Cf., por exemplo, Teitel (2000), Roht-Arriaza e Mariezcurrena (2006), Elster (2004), Sikkink (2011), Sikkink e Walling (2010), Posner e Vermeule (2003), Olsen, Payne e Reiter (2010). Para alguns pesquisadores, seriam cinco ou mesmo seis obrigações (cf, por exemplo, Cueva, sem data). De todo modo, a descrição da sistematização a seguir contempla também listas mais ampliadas, que em geral desdobram uma ou mais obrigações em duas.

${ }^{3}$ Tanto do ponto de vista da legislação, ampliando os direitos políticos e civis, quanto do ponto de vista dos recursos humanos, de modo que, paulatinamente, pelo menos os antigos violadores de direitos humanos deixem de integrar a burocracia estatal e o governo.

${ }^{4}$ Para a elucidação dos mecanismos do aparato repressivo, a identificação de violadores e daqueles que lutaram contra a repressão, bem como para a elaboração de uma cultura de reprovação ao autoritarismo e à arbitrariedade, a fim de que não se repitam. Para um estudo comparado sobre diferentes Comissões da Verdade, cf. Hayner (2001).

${ }^{5}$ Além do aspecto de justiça no conteúdo retributivo e restaurativo da aplicação de uma sanção penal e/ou administrativa àqueles que cometeram crimes, com o fim da impunidade de violadores de direitos humanos
} 
No Brasil, segundo a literatura, o mecanismo que mais avançou foi a reforma das instituições. Embora em muitos aspectos criticadas, as reparações também tomaram lugar no desenvolvimento da justiça de transição no país. Já o direito à verdade e à memória e o julgamento e a condenação dos agentes da repressão não tinham avançado, pelo menos até o escopo temporal de boa parte dos trabalhos mais aprofundados sobre a temática. ${ }^{7}$ De lá para cá, entre outras coisas, uma Comissão da Verdade foi criada e o STF se deparou com uma oportunidade de reverter a persistente imunidade dos agentes da ditadura civil-militar que violaram direitos humanos no passado. Neste sentido, dois dos quatro mecanismos da justiça de transição foram acionados nos últimos anos, intensificando o debate sobre o tema na agenda da política nacional. Os desenvolvimentos atuais da justiça de transição no Brasil justificam a pertinência da continuidade das pesquisas acadêmicas sobre o assunto.

A Lei de Anistia, publicada em 1979 ainda durante o regime militar, é provavelmente o marco mais importante para a justiça de transição no país. Ao mesmo tempo em que proporcionou uma reoxigenação no cenário político nacional permitindo o retorno de várias personalidades exiladas, libertando da prisão e devolvendo direitos civis e políticos a outras tantas, a Lei de Anistia deu início à ideia - que se mostraria vitoriosa com o tempo - de uma redemocratização reconciliada no Brasil. A partir de seus termos, opositores e partidários do regime militar poderiam começar o processo de esquecimento das violações do passado, reputando-se mutuamente isentos de qualquer tipo de responsabilidade penal ou administrativa. Este "pacto" de "perdão" e esquecimento seria imprescindível para dar lugar a um processo seguro de transição, o qual não ocorreria, nos termos desta visão, caso a imunidade dos agentes do Estado que cometeram crimes durante a ditadura também não fosse assegurada. ${ }^{8}$

ocupantes de posições importantes no regime autoritário precedente, estabelece-se uma ruptura em relação ao passado de arbitrariedades, gerando credibilidade social à instauração do Estado de Direito, sob o qual ninguém pode ficar a salvo da imposição da lei e dos direitos humanos.

${ }^{6}$ Por meio do cumprimento desta obrigação, o regime que sucede o autoritarismo assume a responsabilidade pelas violações do passado. Além do aspecto da justiça corretiva para os indivíduos e familiares que tiveram suas vidas prejudicadas (de diferentes formas: do exílio, exoneração de cargos públicos, até o homicídio, o desaparecimento forçado e a tortura), a reparação material das vítimas das violações também tem o condão de deixar claro que, no novo regime, qualquer vítima de arbitrariedades por parte do Estado será indenizada. Já a reparação simbólica visa a reverter a antiga pecha de "terroristas" e esteriotipações do gênero àqueles que lutaram ou resistiram de alguma forma ao autoritarismo. Embora uma visão da justiça de transição apenas como "mecanismos" seja criticável (Cf., por exemplo, Cueva, sem data e Quinalha, 2012), a classificação dos mecanismos é útil para a avaliação das medidas de implementação das expectativas normativas do campo.

${ }^{7}$ Vide nota 1.

8 "Pacto" e "perdão" são colocados aqui entre aspas porque não se referem à conceituação típica contida nestes termos. Um pacto ou acordo propriamente dito pressupõe um equilíbrio de forças entre as partes, o que não era o caso entre situação e oposição durante o regime militar, mesmo na época conhecida como sua "distensão" (as ameaças à cassação de opositores mais radicalizados continuavam a ser constantes, para se 
Em 1985, junto com a convocação da Assembleia Constituinte, foi encaminhado ao Congresso um texto que tratava da anistia concedida aos militares cassados desde 1964. Isso teria sido suficiente, segundo Glenda Mezarobba (2006, p. 56), para o surgimento de uma corrente no Congresso que passaria a vincular a anistia à Constituinte, atribuindo-lhe status de norma constitucional. Nos anos democráticos que se seguiram, apenas a partir dos governos Fernando Henrique Cardoso (1995 a 1998 e 1998 a 2002) a justiça de transição no Brasil voltaria a ser ampliada. A Lei 9.140/1995, que estabeleceu a Comissão Especial de Mortos e Desaparecidos Políticos (CEMDP), e a Lei 10.559/2002, que criou a Comissão de Anistia, trouxeram avanços, como o reconhecimento da morte e a reparação de familiares dos desaparecidos (Cf. Mezarobba, 2010, p. 111). Por meio das indenizações, houve o reconhecimento da responsabilidade do Estado perante os perseguidos políticos. Mas Janaína de Almeida Teles (2005, p. 08), por exemplo, destaca que a Lei dos Desaparecidos ficou limitada pelos parâmetros da anistia e de sua interpretação enquanto recíproca.

Em 2008, o Conselho Federal da OAB protocolou uma ação judicial de controle concentrado de constitucionalidade, pela qual visava a obter declaração do STF acerca da não-recepção, pela Constituição de 1988 , da isenção de responsabilidade penal e administrativa dos agentes do regime militar que violaram direitos humanos. ${ }^{9}$ Por sete votos a dois, o Supremo julgou a ação improcedente. O Acórdão ${ }^{10}$ considerou a Lei de Anistia um "momento histórico" da "transição conciliada" que teria possibilitado a "migração da ditadura para a democracia". Ainda de acordo com a decisão, somente encarando a Lei de Anistia como uma "lei-medida", na peculiaridade histórica de seu propósito, que se poderia entender o conceito da expressão "crimes conexos" (STF, 2010).

Ainda mais recentemente, visando a dar cumprimento ao direito à verdade e à memória, a lei que cria a Comissão Nacional da Verdade prevê como finalidade da Comissão examinar e esclarecer, no âmbito da Casa Civil da Presidência da República, as graves violações de direitos humanos praticadas no período de 1946 a 1988, a fim de promover a "reconciliação nacional". Presente também na lei que criou a Comissão de Mortos e Desaparecidos Políticos em 1995, bem como em votos do julgamento do STF

dizer o mínimo). Da mesma forma, o perdão em seu sentido político (discutido, por exemplo, por Hannah Arendt em A condição humana) não implica esquecimento. Somente pode perdoar em sentido próprio quem, apesar de ter o poder de punir, decide abrir mão da punição. Somente nestes termos, o perdão pode mostrar que, apesar de não punidos em sentido penal, os crimes realizados são condenáveis. Sobre o conceito de perdão aplicado à justiça de transição na África do Sul, cf. Teles (2007).

${ }^{9}$ Neste sentido, a expressão "crimes conexos", encontrada no $\S 1^{\circ}$ do art. $1^{\circ}$ da Lei de Anistia, não poderia estender os benefícios da lei àqueles agentes.

${ }^{10}$ Pode ser obtido em: http://redir.stf.jus.br/paginador/paginador.jsp?docTP=AC\&docID=612960. 
comentado acima, e tendo sua origem na própria Lei de Anistia, o objetivo da “(re)conciliação nacional" reaparece como central no desenvolvimento da justiça de transição no Brasil. Levando em conta este objetivo, e se referindo à necessidade de observância da Lei de Anistia, o dispositivo legal que cria a Comissão da Verdade também assegura que os trabalhos de seus membros não terão caráter jurisdicional.

No Brasil, desde o primeiro mandato de Fernando Henrique Cardoso, o governo federal foi empossado em boa parte por antigos opositores do regime militar. Levando em conta a liderança do policy-making pelo Executivo no país, algumas instituições da sociedade civil (nacional e transnacional) mais ligadas à temática da justiça de transição ${ }^{11}$ esperavam uma maior contundência destes governos na dissolução dos chamados “entulhos autoritários” encontrados na legislação e em órgãos do Estado brasileiro.

As limitações da justiça de transição no Brasil e seus efeitos são abordados pela literatura geralmente pelo lado do problema da edificação do Estado de Direito na democracia brasileira. Argumenta-se que, se não há uma punição exemplar dos agentes do Estado que cometeram crimes contra a humanidade no período autoritário, míngua a credibilidade da lei e da justiça. ${ }^{12}$

A especificidade da abordagem desta pesquisa, por outro lado, assenta-se no argumento de que a manutenção dos termos da anistia tal como essencialmente elaborada ainda durante o governo Figueiredo sedimenta, pelo menos a partir de algumas das instituições políticas mais importantes do Estado brasileiro, uma imagem acerca do processo histórico da redemocratização enquanto uma experiência dependente de concessões realizadas ainda durante o período militar. Mais do que os efeitos negativos, como destaca a literatura, sobre a consolidação dos direitos civis, a sedimentação de uma tal imagem sobre a redemocratização parece se apresentar como um limite à força política das instituições brasileiras na condução ou na alteração dos rumos da justiça de transição até o presente.

\section{A abordagem do tema no nível do "discurso"}

Boa parte da disputa política se dá em torno da atribuição de sentido aos eventos históricos e às categorias políticas. Apropriações distintas sobre o sentido de uma

\footnotetext{
${ }^{11}$ Tais como a Comissão de Familiares de Mortos e Desaparecidos Políticos, o Coletivo de Mulheres pela Verdade e Justiça, o International Center for Transitional Justice (ICTJ) e a Anistia Internacional, para citar algumas da organizações atuantes nesta área.

${ }^{12}$ Cf., por exemplo, Piovesan (2010); Sikkink e Walling (2010); Ventura (2011); Pereira (2005).
} 
realidade mostram que a ordem social pode ser (re)construída de diferentes modos. Ciente disso e preocupado com o potencial disruptivo destas disputas, Hobbes, ao cunhar o conceito moderno de Estado, confere ao Leviatã justamente a tarefa primordial de dar unicidade aos sentidos da política e do direito. O Estado moderno hobbesiano tem a função de assentar o significado dos conceitos mais relevantes da vida pública.

Em Discursos sobre a primeira década de Tito Lívio, Maquiavel sugere que o sentido atribuído à fundação de um Estado ${ }^{13}$, seja ele uma república ou um principado, tem certa ascendência sobre o devir da política. Com seu conceito de fortuna, a qual em boa parte definiria os rumos da vida dos homens, Maquiavel apresenta uma concepção de política em que o princípio de inércia tem um lugar central. A menos que um homem público ou um grupo de homens virtuosos ${ }^{14}$ tenham a habilidade e a perspicácia política necessárias para dobrar a fortuna e mudar os rumos tomados a partir da fundação, dificilmente ocorrerá a mudança. Se a origem for entendida como torta, ela poderá ser corrigida, mas não sem dificuldades. Os mitos da república romana, os quais não eram necessariamente fidedignos à realidade, inspiravam a ação e a virtude cívicas.

No primeiro capítulo do Livro I dos Discursos, Maquiavel (2007, p. 11) fala de duas hipóteses sobre a origem de Roma, contudo, "seja qual for o modo considerado, [quem examinar sua edificação] verá que Roma teve um princípio livre”. O que importa salientar aqui é o seguinte: se há duas hipóteses sobre a origem de Roma, pelo menos uma delas deve não corresponder à realidade. Entretanto, não é esta correspondência que está em foco para Maquiavel, mas sim a ascendência heurística que o sentido atribuído ao princípio tem sobre o devir da política. Sendo assim, mesmo com dois sentidos sobre a origem de Roma em disputa, o fato de ambos remeterem a um princípio livre confere grande vantagem para a manutenção da liberdade no curso da vida política da República romana.

Por isso, talvez não seja trivial perguntar: qual o sentido oficioso ${ }^{15}$ que algumas das principais instituições políticas do Estado brasileiro têm atribuído ao que elas entendem por fundamentos da redemocratização no Brasil? Se a política é também uma disputa de sentidos, o sentido da fundação de um Estado (hoje diríamos regime) tem particular importância para a história do pensamento político. Ainda que fosse fiel à realidade da

\footnotetext{
${ }^{13} \mathrm{O}$ conceito de Estado tal como o entendemos ainda hoje é inaugurado por autores do pensamento moderno, mas, em $O$ Príncipe, Maquiavel já utiliza o termo "Estado" para indicar depois suas duas formas.

${ }^{14}$ Aqui remetendo-se ao conceito de virtù tal como definido por Maquiavel em $O$ Príncipe.

${ }^{15}$ Digo "oficioso" e não "oficial" porque este se refere a um ato emanado do governo ou de uma autoridade administrativa e certificado pela autoridade pública competente. Já "oficioso" remete ao que não tem caráter oficial, isto é, carece de certificação, apesar de provir de fonte pública.
} 
transição brasileira (o que não parece ser o caso), um sentido oficioso sobre uma redemocratização reconciliada e por isso dependente se ergue, de saída, como um obstáculo à autonomia de nossas instituições políticas, se não no aprofundamento da democracia, pelo menos no aprofundamento da justiça de transição, uma vez que esta estaria condenada a respeitar o pressuposto de apaziguamento contido na categoria de "conciliação nacional". 16

\section{Justificativa da relevância do tema}

É comum encontrarmos no pensamento político brasileiro explicações a respeito das "raízes", "origens", "formação" - e termos parecidos - dos problemas políticos e sociais enfrentados no presente. Mas talvez justamente em função da característica quase genealógica de algumas destas perspectivas, estas "raízes" dos problemas do presente são investigadas, muitas vezes, em um "passado longínquo", como a escravidão ou o clientelismo português (Cf. Safatle e Teles, 2010, p. 9). Vladmir Safatle e Edson Teles afirmam que uma tal perspectiva prejudica e subestima a visada dos fundamentos mais recentes que, pelo menos com igual contundência, configurariam os impasses do presente.

Nenhum "impasse" talvez tenha sido mais marcante em nosso recente passado político e social do que a experiência do regime militar. Ainda assim, boa parte da ciência política brasileira, nos últimos anos, tende a destacar, sobretudo, os aspectos da consolidação da democracia no país. E para tanto esta literatura se vale de análises institucionais, dando atenção especialmente às instituições ligadas ao processo legislativo, partidário e eleitoral. Se o consociativismo fora a tônica da democracia entre 1945 e 1964 e mesmo nos primeiros anos do regime democrático estabelecido propriamente a partir da promulgação da Constituição de 1988, desde o primeiro governo Fernando Henrique Cardoso o país veria o que se convencionou nomear de "presidencialismo de coalizão" (Cf. Palermo, 2000; Figueiredo e Limongi, 1999). Os poderes pró-ativos da Presidência, como a ampliação da possibilidade de edição de Medidas Provisórias, sua prevalência (de

\footnotetext{
${ }^{16}$ Vale destacar que o recorte aqui traçado tem um paralelo com a tese de José Murilo de Carvalho desenvolvida no segundo capítulo, "As proclamações da República”, de seu livro A Formação das almas: o imaginário da República no Brasil (2009). Nele o autor trata da tentativa dos golpistas de 15 de novembro de 1889 de construir uma versão oficial dos fatos destinada à história, estabelecendo uma espécie de mito de origem da República. Neste capítulo, entretanto, Carvalho ressalta que o advento da República não deveria ser reduzido à questão militar. João Quartim de Moraes $(1989$, p. 75) também ensaiou argumento parecido, pois, para ele, a ideia de Marechal Deodoro como aquele que "proclamou" a República era uma forma de assinalar que ela, entre nós, nascera de um golpe militar, portanto graças às Forças Armadas, que já se colocavam assim como o baluarte final dos interesses da nação.
} 
fato e de direito) na iniciativa legislativa e, principalmente, a capacidade dos últimos governos de compor alianças promoveriam a superação dos obstáculos consociativos (notadamente a fragmentação partidária, o bicameralismo, o federalismo e o fisiologismo) e dariam os contornos da atual governabilidade do país, a última fronteira garantidora da estabilidade democrática na visão destes estudos. Em outros termos, segundo esta literatura, os principais perigos que haviam ameaçado a democracia anterior estariam afastados desde meados da década de 1990.

Por isso, de um lado, para alguns dos autores mais importantes do pensamento político e social brasileiro, como Raymundo Faoro, Caio Prado Júnior e Sérgio Buarque de Holanda, os principais empecilhos ao avanço brasileiro rumo à modernidade viriam de longo prazo e, inclusive, muitas vezes até fugiriam ao alcance das fronteiras nacionais (como a "transposição do Estado português" ou a dependência de nossa economia monocultora e agrário-exportadora em relação às oscilações do mercado internacional). De outro lado, para boa parte da ciência política contemporânea, as instituições políticas do presente e o desempenho dos principais atores políticos (os governos, os partidos e o Judiciário) apontariam para a consolidação da democracia por aqui, afastando, assim, os fantasmas da instabilidade e de um eventual novo golpe militar. Neste sentido, então, o passado recente como questão de interesse para a problematização da política no presente restaria duplamente obliterado.

Não se trata de contestar estas literaturas aqui ou no desenvolvimento da tese. Mas trata-se de investigar alguns elementos do autoritarismo que, a despeito dos avanços institucionais desde a redemocratização, ainda persistem e prejudicam, num certo sentido, a construção de uma auto-imagem da democracia brasileira enquanto uma experiência plena e autônoma. Mais especificamente, o objetivo é avaliar se e em que medida uma imagem sobre a redemocratização brasileira mobilizada por elites políticas tem repercutido nas políticas de justiça de transição do país.

A primeira hipótese da pesquisa é a de que o discurso da "conciliação nacional", veiculado pelo menos desde a elaboração do projeto de anistia pelo governo Figueiredo, continua a ser um dos principais empecilhos ao desenvolvimento da justiça de transição no Brasil. Mas a segunda hipótese sustenta que, dos últimos trabalhos mais aprofundados sobre o tema para cá, este discurso passou a ter sua hegemonia contestada de forma significativa, sendo obrigado a ceder a algumas das demandas de entidades da sociedade civil que até pouco tempo atrás não eram consideradas como negociáveis, principalmente o compromisso da Comissão Nacional da Verdade de revelar o funcionamento do aparato 
repressivo e identificar nomes e condutas criminosas dos agentes da repressão. Essencialmente, uma nova tese se justifica porque, conforme estas hipóteses, passamos de um momento de hegemonia do discurso da "conciliação nacional" ${ }^{17}$ para um momento de uma hegemonia em crise, significativamente contestada.

Mas o discurso hegemônico ainda mostra sua força nos últimos anos, por exemplo, na decisão do STF na Arguição de Descumprimento de Preceito Fundamental (ADPF) 153. Traços desta hegemonia também podem ser encontrados na própria literatura que critica as limitações do desenvolvimento da justiça de transição por aqui, como veremos em alguns casos neste texto. ${ }^{18}$

\section{O estudo de um discurso político não "intelectual" em sentido estrito}

Em um dos fragmentos da aula que preparava para a defesa de sua titularidade, Gildo Marçal Brandão (2010a, pp. 303 e 304), tentando dar continuidade à fundamentação teórica que levava adiante nos últimos anos a respeito de uma história político-social das ideias no Brasil, assevera que uma tal história teria, basicamente, dois vetores analíticos ${ }^{19}$ : o primeiro se refere a análises sobre expressões intelectuais no Brasil como movimentos, atividade coletiva, e neste vetor, também estariam as grandes obras que, embora não sejam parte de um "movimento", podem ser encaradas como "individualidades significativas"; no segundo vetor, do qual se aproxima esta pesquisa, tratar-se-ia, em suas palavras, de “investigar como as ideias fizeram a cabeça de grupos sociais e profisssionais, converteram-se em projetos que exprimem ou estão em busca de atores, transformam-se em direção intelectual e moral”.

\footnotetext{
${ }^{17}$ Este discurso é referido em outros trabalhos com outros nomes em função de abordagens distintas. Por exemplo, em Heloisa Greco (2003), ele aparece como "discurso" ou "memória instituinte"; em Edson Teles (2007), como "memória do consenso". Para este último autor, a "memória do consenso" seria uma espécie de meio-termo entre a memória dos militares e a memória dos familiares de perseguidos políticos, ambas também, assim como toda memória de um grupo, seriam objeto de uma redução a partir das visões particulares de diferentes sujeitos.

${ }^{18} \mathrm{O}$ discurso da "conciliação nacional" no Brasil também se estrutura de forma mais ou menos concomitante à ascensão da transitologia na América Latina, tendo com ela muitos pontos em comum. Não é por outro motivo que, segundo Renan Quinalha (2012), até hoje, parte do debate atual ainda seja marcado por um receio de uma "regressão autoritária". Naquela literatura, eram recorrentes as recomendações de cautelas que seria preciso tomar, especialmente no que diz respeito à aplicação de uma justiça retributiva, em vista de se evitar um "colapso" do processo transitório. Assim como os documentos que constituem o material básico da pesquisa, a transitologia e a consolidologia estão em boa parte ultrapassadas na explicação da realidade efetiva da transição, mas são importantes para o entendimento da realidade efetiva de uma concepção sobre a redemocratização no Brasil.

${ }^{19}$ Os dois vetores são desenvolvidos a partir de sugestão elaborada por Élide Rugai Bastos (2002).
} 
E esta investigação deveria levar em conta também a análise de produção de ideias fora do universo acadêmico ou de autores considerados como intelectuais em sentido estrito: "Tomada como variável independente, [...] [a diferença entre produção acadêmica e pré-acadêmica] nos arrastaria inevitavelmente para uma análise interna à academia, do choque de ambientes e tradições acadêmicas distintas, das 'lutas entre os intelectuais', etc., quando o que nos interessa é ver como a sociedade, os diversos grupos sociais produziram os intelectuais de que necessitam por meio da academia $[\ldots]$ ”.

O conceito de "intelectual" em Gramsci me parece o mais apropriado no âmbito desta tarefa. Particularmente no Caderno 12 dos Cadernos do Cárcere, Gramsci considera como intelectuais todos aqueles que estão engajados em algum tipo de elaboração de discurso no âmbito de alguma especialização funcional. Além daqueles usualmente tidos como intelectuais, como os acadêmicos, os escritores e os filósofos, também eclesiásticos, políticos, dirigentes sindicais etc podem ser considerados como tal. Aliás, acredito que Brandão (2010b) também tinha em vista o conceito gramsciano de "intelectual" quando falava da necessidade de uma historiografia das ideias extrapolar o âmbito dos trabalhos estritamente acadêmicos ou "intelectuais" em sentido estrito.

Entre os principais interesses de se estudar obras de um autor "clássico" do pensamento político estão não apenas a busca de um entendimento sobre o pensamento deste autor, mas, por meio de uma avaliação crítica sobre sua obra, a compreensão de aspectos da própria dinâmica político-social. Porém, em muitos casos, se estes autores oferecem um ganho explicativo e mesmo normativo sobre aspectos importantes da economia, da sociedade e da política, nem sempre têm a mesma importância do ponto de vista da força social ou institucional de suas ideias. Autores do chamado "idealismo constitucional” (Brandão, 2010b), por exemplo, por conta da escassez de portadores sociais de suas ideias, tiveram, pelo menos por um longo período no século $\mathrm{XX}$, um impacto relativamente menor neste aspecto.

No caso desta pesquisa ocorre uma situação diferente: a investigação das principais categorias e ideias no material selecionado pode não ser um registro adequado para se entender o processo real da redemocratização, mas, por ter certa ascendência sobre elites políticas envolvidas no desenvolvimento da justiça de transição, a depuração dos pressupostos deste registro pode trazer um ganho explicativo sobre como estas elites 
encaram aquele processo e, imbuídas deste entendimento, qual a compreensão delas sobre até que ponto pode avançar a justiça transicional. ${ }^{20}$

Não pretendo adotar aqui o enfoque metodológico da chamada "história dos conceitos" para depurar o desenvolvimento da "conciliação nacional" no recorte proposto. Mesmo porque esta metodologia me prenderia a um modo muito particular de proceder e também porque tenho minhas dúvidas se a categoria central de "conciliação nacional" (e outras a ela associadas) tal como mobilizada e reconstituída na tese configuraria propriamente um "conceito" do ponto de vista da Begriffsgeschichte. Por outro lado, a "história dos conceitos" me parece bastante útil para dar uma fundamentação teórica ao meu argumento neste ponto, isto é, de que há uma relação bastante próxima entre a história social (ou material) e uma história das ideias ou espiritual. ${ }^{21}$ Minhas hipóteses centrais trabalham justamente com este aspecto: uma relação entre o que chamo de discurso da "conciliação nacional" e os limites e possibilidades de desenvolvimento da justiça de transição no Brasil.

No capítulo de Futuro Passado em que analisa mais detidamente a relação entre história social e história dos conceitos, o próprio Koselleck (2006b, p. 98) assevera que, sem um referencial linguístico comum, os projetos de ação política dificilmente teriam uma unidade de desígnio. Ou, conforme sustentaria em outro texto (Koselleck, 2006a, p. 106), a história dos conceitos seria evidência linguística de continuidades sociais.

Neste mesmo sentido, descrevendo os trabalhos de Koselleck e Melvin Richter, Marcelo Jasmin e João Feres Júnior (2006, p. 23) sustentam que estes autores estão interessados em verificar se mudanças e continuidades no referencial de uma linguagem podem influenciar as ações no âmbito do governo e da sociedade. Seguindo esta chave analítica, por exemplo, em um de seus estudos, Marcelo Jasmin (2007, pp. 172 e 173) assevera que a trajetória dos usos de um determinado referencial linguístico pode resumir um período da própria sociedade e, desta forma, uma linguagem política corrente seria um bom guia para a percepção de mecanismos de naturalização do status quo. Desestabilizar um ordenamento social, jurídico e político exigiria um esforço de desnaturalização linguística. Neste texto, Jasmin lança as bases para um estudo do conceito de "história" elaborado pelos intelectuais do Estado Novo em vista de viabilizar uma ordem social

\footnotetext{
${ }^{20} \mathrm{O}$ material básico da pesquisa são: 1) o projeto governista de anistia, desenvolvimentos posteriores e o chamado programa brasileiro de reparações (capítulo 2); 2) o julgamento da ADPF 153 no STF e o desenvolvimento das ações penais promovidas pelo MPF contra agentes da repressão (capítulo 3); 3) e os trabalhos da Comissão Nacional da Verdade e seu relatório final (capítulo 4).

${ }^{21}$ Para utilizar termos mais amplos e não me comprometer aqui com a definição estrita de "conceitos" que podemos encontrar em Koselleck (2006b).
} 
autoritária, mas que, ao mesmo tempo, desse suporte a um caráter "moderno" no bojo da ditadura varguista. Da mesma forma que o conceito de "história" no Estado Novo, minha sugestão aqui é a de que a categoria central de "conciliação nacional" (tanto durante a transição brasileira quanto nos desenvolvimentos da justiça de transição) selaria um horizonte de possibilidades e impossibilidades de ações. ${ }^{22}$

A maior parte dos estudos preocupados com "representações" (no sentido filosófico, que pode ser entendido, a partir de diferentes abordagens, como "imagens", "interpretações", "ideias", "memórias", “discurso" etc) elaboradas por grupos políticos sobre o período militar ou sobre a transição valeu-se de um campo metodológico relacionado a "memória", não a "discurso". Os trabalhos que se referem a "memórias" realizam pelo menos duas operações importantes: uma desconstrução das razões que se prestavam a justificar o autoritarismo do regime militar como um mal menor, e uma certa redenção - não da "negociação pragmática" de uma oposição "responsável", automaticamente já redimida -, mas de oposições consideradas como mais "radicais" à ditadura, como a luta armada. Com uma perspectiva um pouco diferente, o objeto aqui não são propriamente representações que determinados grupos políticos têm sobre o papel desempenhado por partidários ou opositores à ditadura, mas são representações que determinados grupos políticos (mais especificamente elites políticas envolvidas com a justiça de transição no Brasil) têm sobre o que seriam os fundamentos da redemocratização no país, e como estas representações (aqui entendidas como um discurso) se refletem no alcance das expectativas normativas da justiça transicional.

Analisar é decompor, dividir, desconstruir, para mostrar os pressupostos e uma visão de mundo implicados em um discurso, e, deste modo, desnaturalizá-lo. Há basicamente duas formas de se narrar a história: como mito ou como esclarecimento. Esta última perspectiva envolve, necessariamente, uma postura crítica em relação ao objeto.

\section{Estrutura da tese}

A tese terá a seguinte estrutura:

1) Capítulo teórico e crítico sobre os parâmetros normativos da justiça de transição. Boa parte dos trabalhos mais aprofundados sobre a temática da implementação

\footnotetext{
${ }^{22}$ Como já mencionei acima, refiro-me preferencialmente a "categorias" e não a "conceitos" porque não se trata aqui de defender que as principais categorias político-sociais em jogo no "discurso da conciliação nacional" teriam a densidade e complexidade de "conceitos" políticos, tal como definidos, por exemplo, por Koselleck (2006b). O termo "categorias" é mais abrangente e suficiente para o meu argumento.
} 
da justiça de transição no Brasil não partiram explicitamente de uma discussão sobre o pano de fundo teórico do campo. Fazer esta discussão permitirá uma precisão conceitual maior para a avaliação, nos capítulos seguintes, das potencialidades e dos limites das políticas públicas voltadas à responsabilização, à sanção, à memória etc.

2) Capítulo de reconstituição bibliográfica sobre estudos atinentes ao desenvolvimento da justiça de transição no Brasil. A reconstituição bibliográfica auxiliará na reconstituição do discurso político de uma certa visão oficiosa sobre a redemocratização no país presente nos desenvolvimentos da anistia e depois transformada pelos trabalhos das comissões de reparação. A propósito da avaliação destas comissões, aliás, procurarei realizar uma revisão da bibliografia, que em alguns aspectos está desatualizada.

3) O terceiro capítulo fará uma discussão crítica do julgamento da ADPF 153 (que considerou a chamada "bilateralidade" da anistia como recebida pela Constituição de 1988) e dos desenvolvimentos das ações penais promovidas pelo MPF contra agentes da repressão política no Brasil durante o regime militar.

4) O quarto e último capítulo cuidará dos trabalhos da Comissão Nacional da Verdade e seu papel fundamental na virada em favor da memória sobre o passado de violações e em favor da responsabilização de agentes da repressão, frente ao acúmulo de décadas anteriores de negacionismo estatal.

Ao cabo, um balanço do percurso traçado a título de considerações finais. 


\section{Capítulo 1. Justiça de transição: teoria e prática}

Como foi ressaltado na introdução, o objetivo central da tese não é fazer uma discussão teórica ou uma crítica sobre a evolução empírica dos horizontes normativos da justiça de transição em geral, mas reconstruir a evolução do campo no Brasil e os impactos que uma auto-representação da experiência democrática no país tem sobre ele. Entretanto, não será possível fazer uma avaliação crítica da experiência brasileira sem antes munir o texto de um arsenal teórico e de um referencial empírico e comparativo a respeito da evolução do campo nas últimas décadas. Ou pelo menos, sem uma tal digressão, a abordagem do objeto central a partir dos próximos capítulos tenderia a ser mais rasa.

Nos últimos anos houve um estrondoso crescimento na produção de pesquisas no campo, de modo que, se em princípios da década de 2000 era possível ler virtualmente todas as pesquisas mais importantes produzidas na área, hoje uma tal possibilidade já está bastante distante. Ainda assim, poucos são os trabalhos que encaram a tarefa de realizar reflexões com maior densidade teórica ou normativa ou mesmo que tecem suas considerações críticas a partir de uma reconstrução da evolução histórica da implementação das políticas associadas à justiça de transição. ${ }^{1}$ A maioria das pesquisas tem se dedicado a análises empíricas de experiências específicas ou em perspectiva comparada, mas sempre com o escopo limitado a, no máximo, alguns poucos países. ${ }^{2}$

\footnotetext{
${ }^{1}$ Pablo de Greiff (2012 e 2010) é um dos que ensaiou mais tentativas de imbuir o campo de maior densidade teórica e normativa. Teitel (2000), Roht-Arriaza e Mariezcurrena (2006), Elster (2004), Sikkink (2011), Sikkink e Walling (2010), Posner e Vermeule (2003), Olsen, Payne e Reiter (2010) compõem a lista dos trabalhos mais influentes no que se refere a reconstruções críticas sobre a evolução empírica do campo.

${ }^{2}$ Isso, por um lado, talvez seja, pelo menos em parte, resultado da dinâmica da produção acadêmica na atualidade, cada vez mais engajada na publicação de artigos do que de livros (sendo que os livros muitas vezes são compostos por compilações de artigos sobre o mesmo tema). Por outro lado, também tem a ver
} 
Além disso, no Brasil, existem pouquíssimas traduções dos trabalhos mais importantes na área, com exceção de alguns artigos. E apesar do crescimento exponencial da pesquisa, sobretudo a partir do Direito, a maioria dos trabalhos realizados no país também tem o foco em análise de casos específicos e somente a propósito deste enfoque os pesquisadores se enveredam por algumas considerações teóricas. Já existem bons artigos em português que tratam de assuntos mais teóricos sobre o tema (publicados sobretudo pela Revista Anistia Política e Justiça de Transição, editada pelo Ministério da Justiça), mas carecemos ainda de trabalhos de maior fôlego neste sentido. ${ }^{3}$

Considerando estes motivos, julguei pertinente dedicar um capítulo para esta digressão. Contudo, como se trata de apenas um capítulo, o empreendimento aqui não poderá fazer justiça ao nível de detalhamento que o tema merece. Ainda assim, poderá contribuir para a continuidade da nacionalização do debate sobre justiça de transição a partir de um entendimento mais assentado sobre as bases teóricas e empíricas do campo.

Há basicamente dois objetivos centrais neste capítulo: em primeiro lugar, realizar uma breve incursão crítica sobre os pressupostos teóricos e normativos do campo, que apenas muito recentemente começaram a ser debatidos de forma um pouco mais sistemática pela literatura. O segundo objetivo será traçar o desenvolvimento histórico da justiça de transição nas últimas décadas a partir de alguns de seus mais importantes mecanismos (as políticas públicas de reparações, verdade e justiça) e elementos que muitas vezes compõem o seu funcionamento (como as anistias, uma visão particular da rule of law, a reconciliação, a responsabilidade individual etc). Por razões mais didáticas do que epistemológicas (afinal teoria e prática se alimentam mutuamente), procurarei tratar por vezes dos dois objetivos separadamente, mas por outras será necessário (e acredito mesmo mais esclarecedor) tratá-los de forma entrelaçada.

$\mathrm{Na}$ genealogia que desenhou em um de seus artigos sobre o tema, Ruti Teitel (2003) indica que o campo teria passado basicamente por três fases de desenvolvimento. Primeiramente o pós-guerra, com o marco dos julgamentos de Nuremberg, que teriam lançado as bases para tornar o indivíduo sujeito do direito penal internacional. Este primeiro e paradigmático momento, entretanto, teria sofrido com o esgarçamento das

com a dificuldade - apontada por Priscilla Hayner (2011) - de se levar adiante pesquisas quantitativas e mesmo qualitativas no campo, em função de haver muitas variáveis independentes (de ordem doméstica, internacional e transnacional) a influenciarem os rumos da implementação das políticas, de modo a ser arriscado, para o rigor da pesquisa, isolar uma ou outra variável para verificar seu impacto.

${ }^{3}$ Importante exceção é o livro de Renan Quinalha (2012), resultado de sua dissertação de mestrado em Direito pela Faculdade de Direito da Universidade de São Paulo. Ainda assim, Quinalha dedica cerca de um terço de seu livro ao tema da justiça de transição, dando atenção para os campos da transitologia e da consolidologia (que correspondem a dois momenta de uma mesma literatura) nos outros dois terços do livro. 
tensões geopolíticas no contexto da Guerra Fria, quando o mundo voltou a se fechar mais para a influência normativa do direito internacional público dos direitos humanos. A segunda fase coincidiria com a terceira onda de democratizações, que afetou o sul da Europa e a América Latina (a partir dos anos 1970) e alcançou o leste europeu, África e América Central (no final dos anos 1980 e no curso dos 1990). Nesta fase, na medida em que a justiça de transição teria coincidido com processos de formação ou reformulação de Estados Nação, a implementação das políticas teria seguido mais de perto a dinâmica dos processos políticos, sociais e culturais por que passavam estes países. Já a terceira fase do campo abrangeria o fim do século XX em diante, quando a justiça de transição alcançaria um período de sedimentação de um senso comum a respeito dos mecanismos associados ao campo, o que representaria um processo de globalização de seu paradigma. Neste sentido, conforme assevera Quinalha (2012, p. 71), a justiça de transição está associada a uma ideia de "justiça global" ou "transnacional", viabilizada em função do desenvolvimento histórico do direito internacional dos direitos humanos.

De acordo com Ellen Lutz (2006), as políticas de justiça transicional são geralmente justificadas com vistas a dois objetivos inter-relacionados: responder ao sofrimento causado por violações do passado e impedir que violações similares ocorram no futuro. Os primeiros países engajados na terceira onda de democratização não tinham a vantagem de se valerem de outras experiências similares para estruturar suas próprias políticas de justiça transicional. Também não tinham às suas mãos a jurisprudência da Corte Interamericana de Direitos Humanos e dos Tribunais Internacionais para a Antiga Iugoslávia e Ruanda. É neste contexto que autores como Huntington (1991), por exemplo, acreditavam que as tentativas de aplicação de uma justiça retributiva para punir violadores de direitos humanos diminuíam com a distância entre as violações e a transição.

Entretanto, a literatura mais recente tem mostrado que o interesse político internacional pela justiça de transição aumentou tanto nos últimos anos que já não é mais possível aos governos simplesmente varrer o passado para debaixo do tapete. Como sustentam Sikkink e Walling (2006), as oportunidades políticas e legais são hoje, em nível transnacional, bastante favoráveis às políticas justransicionais. ${ }^{4}$

O caso da extradição de Pinochet, por exemplo, não foi resultado de decisão do Conselho de Segurança da ONU sobre como responder a atrocidades massivas cometidas

\footnotetext{
${ }^{4}$ Apesar disso, alguns dos antigos argumentos, como a questão de se achar que a incidência de julgamentos retrospectivos diminui conforme a busca por justiça se distancia do momento da transição e uma concepção de trade off entre justiça e verdade, aparecem ainda com força em renomados autores que produziram obras recentes sobre a temática, como Jon Elster (2004, p. 116-17 e capítulo 8).
} 
sob o comando do antigo ditador, mas sim de um movimento transnacional apoiado pela legislação internacional e por Estados comprometidos com a rule of law e com a realização de objetivos justransicionais que o Chile pós-transição não foi capaz de realizar. ${ }^{5}$

Em outro texto, Roht-Arriaza e Sikkink (2001) mostram que casos como este até têm forçado alguns países a abrirem mão de suas anistias, para não verem sua soberania desafiada internacionalmente a propósito de processos contra perpetradores nacionais realizados em outros países à revelia de legislação doméstica que eventualmente garanta a imunidade. Muitas vezes, Cortes e governos nacionais preferem continuar com a prerrogativa de decidir sobre o que fazer com seus cidadãos.

Na primeira subseção deste capítulo, o objetivo será dar os contornos de uma discussão teórico-normativa relativamente recente e ainda um tanto incipiente no campo. Na segunda subseção, a ideia será reconstruir a trajetória jurídica e política de alguns dos principais elementos da justiça de transição em nível internacional. Ao cabo, algumas considerações finais.

\section{1) Teoria e Prática}

Como se trata de um campo de natureza indiscutivelmente normativa, não é possível apoiar-se aqui exclusivamente na observação crítica de experiências concretas, sob pena de se formular argumentos funcionalistas ou falácias naturalistas. Mesmo assim, parto do pressuposto de que teoria e prática se comunicam e realimentam constantemente e é inegável que algumas experiências tidas como bem sucedidas têm alimentado a própria produtividade normativa do campo.

Em Transitions from Authoritarian Rule (O'Donnell, Schmitter e Whitehead, 1986), livro paradigmático sobre as transições na América Latina e no leste europeu, os autores chamavam atenção para o dilema entre a exigência moral de se confrontar os crimes dos regimes anteriores e a exigência prática da consolidação democrática, que poderia ser prejudicada pela tentativa de se levar adiante a exigência moral. Os autores asseveravam que este não seria um dilema passível de resolução por pesquisadores e que

\footnotetext{
${ }^{5}$ Sobre o caso de extradição de Pinochet aprovada pela Câmara dos Lordes na Grã-Bretanha e requerida pelo Judiciário espanhol, ver Roht-Arriaza (2005). Neste livro, a autora mostra que a partir deste caso ficou cada vez mais difícil para perpetradores se verem livres de medidas de accountability.
} 
deveria ser tarefa levada adiante pelos líderes políticos, com sensibilidade às dinâmicas e possibilidades de cada contexto.

Para a maioria dos autores do campo da transitologia ${ }^{6}$, a transição ideal implica o menor grau de conflito possível e mobiliza o maior nível de consenso. Na época em que produziram esta literatura (fundamentalmente entre os anos 1980 e 1990), os transitólogos temiam que se os interesses fundamentais das elites dominantes e dos militares (sobretudo na América Latina) não fossem respeitados, haveria risco de retrocessos no caminho à democracia. Para eles, o pior cenário imaginável seria a regressão autoritária. ${ }^{7}$

A coincidência no tempo de várias democratizações após conflitos armados ou ditaduras no fim do século XX ajudou a levantar a questão sobre quais estratégias adotar em um nível de reflexão em alguma medida transnacional. Muito do debate passou a ser enquadrado pelas condições das transições na América Latina e no leste europeu. $\mathrm{Na}$ América Latina, militares foram em geral muito influentes nos próprios processos transicionais, e poderiam de fato ameaçar a transição para a democracia, caso seus interesses mais caros não fossem preservados.

Estas transições também foram em grande parte negociadas pelas elites, e não forçadas pela derrota do poder militar frente a insurreições armadas ou revoluções populares (Cf. Roht-Arriaza, 2006). ${ }^{8}$ Muitos pesquisadores, políticos e mesmo ativistas de direitos humanos acreditavam na época que provocaria grande risco ao processo de redemocratização forçar processos criminais contra antigos violadores de direitos humanos. Neste contexto, as anistias foram muitas vezes concessões, acordos ou imposições inevitáveis: a troca era perder a justiça sobre o passado por uma justiça para o futuro.

Mas o fato é que quando Transitions from Authoritarian Rule ficou pronto para ser publicado, a Comissão Nacional sobre o Desaparecimento de Pessoas (CONADEP), na Argentina, ainda estava em vias de ser implementada e ainda não havia um reconhecimento internacional acerca de um "direito à verdade" e outros mecanismos de

\footnotetext{
${ }^{6}$ Entre estes autores, cf., por exemplo, Huntington (1991), O’Donnell, Schmitter e Whitehead (1986), Linz e Stepan (1996), entre outros.

${ }^{7}$ Sobre visões críticas a respeito da transitologia, ver Quinalha (2012), Vitullo (2005) e Cueva (sem data). Para Vitullo, o fato de os transitólogos assumirem a posição de uma espécie de "conselheiros do príncipe" dos políticos nas transições teria afetado sua capacidade crítica diante dos rumos dos processos transicionais. Cueva chega a afirmar que os transitólogos teriam assumido uma postura de prontidão para o "pactualismo" e que teriam ignorado solenemente os familiares de mortos e desaparecidos políticos.

${ }^{8} \mathrm{O}$ caso argentino talvez seja o mais próximo disso, mas a "derrota" dos militares foi para os ingleses na guerra das Malvinas, o que repercutiu numa espécie de implosão do poder militar internamente, isto é, não como resultado de uma efetiva derrota interna para grupos armados, levante popular ou revolução.
} 
justiça de transição. Já em meados dos anos 1990, o cenário internacional do campo mudou radicalmente e a busca da justiça tem determinado desde então o escopo de boa parte das políticas. Hoje existe um consenso internacional de que o legado de crimes em massa não pode simplesmente ser enterrado, e precisa ser enfrentado de alguma forma.

A ascensão do tema é ratificada por documentos oficiais no mundo todo. $\mathrm{O}$ Relatório do antigo Secretário Geral da Organização das Nações Unidas (ONU) Kofi Annan intitulado "The Rule of Law and Transitional Justice in Conflict and Post-Conflict Societies" oferece uma definição e entendimentos sofisticados sobre o campo. O Secretário Geral (2004, p. 4) definiu a justiça de transição como "toda a gama de processos e mecanismos associados a tentativas das sociedades de acertar as contas com um legado de abusos em larga escala no passado, para assegurar a accountability, servir a justiça e alcançar a reconciliação". 9

Ao lado desta definição, o documento enumera componentes como justiça criminal, elucidação da verdade, reparações e mudanças nos recursos humanos das instituições estatais, que deveriam ser considerados como partes de um todo, isto é, nunca isoladamente.

A sedimentação de um certo senso comum em torno do campo indica que ele saiu de sua infância. Ainda assim, o campo continua tremendamente sub-teorizado. Poucas tentativas neste sentido foram realizadas de forma sistemática, mesmo nos trabalhos mais influentes.

A definição oferecida por Ruti Teitel (2003, p. 69), segundo a qual a justiça de transição é uma "concepção de justiça associada a períodos de mudanças políticas, caracterizada por respostas legais para confrontar as violações de regimes repressivos anteriores" ${ }^{10}$ continua a ser muito influente no campo e compartilhada por outros autores. ${ }^{11}$ Em texto anterior, Teitel (2000, p. 6) também afirmava que "o que é tido como justo [nestes contextos] é contingente e conformado pelas injustiças anteriores". ${ }^{12}$ Por outro lado, Pablo de Greiff (2012, p. 59) afirma que Teitel destaca excessivamente o qualificativo "transição", para caracterizar o campo como uma "justiça extraordinária".

\footnotetext{
${ }^{9}$ No original: "the full range of processes and mechanisms associated with a society's attempts to come to terms with a legacy of large-scale past abuses, in order to ensure accountability, serve justice and achieve reconciliation."

${ }^{10}$ No original: "conception of justice associated with periods of political change, characterized by legal responses to confront the wrongdoings of repressive predecessor regimes".

${ }^{11}$ Cf., por exemplo, André du Toit (2000) e Jon Elster (2004).

${ }^{12}$ No original: "What is deemed just is contingent and informed by prior injustice".
} 
Para ele, não se trata nem de um tipo específico de justiça, nem de uma mera forma de compromisso, mas da aplicação da justiça em circunstâncias "específicas".

Talvez ainda influenciados pela transitologia, os primeiros trabalhos na área davam muita ênfase ao predicado que qualifica a justiça no termo que dá nome ao campo: a transição. Para Teitel, a função da lei neste contexto é profunda e inerentemente paradoxal porque as transições implicam mudanças de paradigmas. Enquanto a lei mantém a ordem nestes períodos, ela também precisa fomentar transformações (Teitel, 2000, p. 6). Muitos dos princípios do direito não se aplicam neste período, assim como o próprio direito passa a assumir uma função transformativa sui generis. Neste sentido, continuaria a ser antes a transição do que propriamente a justiça a guiar o processo.

Do ponto de vista da análise crítica da evolução empírica dos horizontes normativos do campo, acredito que Transitional Justice, de Ruti Teitel (2000),continue a ser o livro mais bem escrito e completo, e por isso fortemente indicado. Entretanto, oproblema deste livro é que ele não dispõe de um conceito preciso de transição. Sem problematizar o conceito de transição, o livro acaba arrastando para o terreno da justiça de transição toda problemática da transitologia e da consolidologia, tidas como ultrapassadas em muitos aspectos.

Também críticos desta visão do campo, para Posner e Vermeule (2003), em Transitional Justice as Ordinary Justice, a excepcionalidade da justiça de transição viria de uma visão estereotipada da justiça ordinária. Por isso, em sua opinião, se ela passar a ser instrumentalizada via Justiça Comum, como uma justiça "regular", não haveria mais razões para colocá-la sob suspeita. Para imbuir seus argumentos de maior força indutiva, os autores tentam mostrar continuidades entre a justiça transicional e a justiça ordinária. Segundo eles (2003, p. 786): "programas de reparação podem ser pensados como apenas mais um programa regulatório - como a Lei sobre Espécies Ameaçadas - ou como programas que alteram direitos de propriedade em busca de algum objetivo social". ${ }^{3}$

No entanto, este tipo de abordagem também é falho porque tende a despolitizar a função da justiça de transição de traçar uma linha divisora em relação a um passado em que os direitos valiam apenas para alguns. Utilizar a justiça ordinária - em que a quebra das normas fundamentais é tida como exceção, não como regra - para sanar violações massivas de direitos humanos associadas a regimes autoritários é indício de uma certa

\footnotetext{
${ }^{13}$ No original: "restitution programs can be thought of as just another regulatory program - like the Endengered Species Act - or a transfer program that unsettles property rights in pursuit of some social goal".
} 
indiferenciação entre uma situação e outra. Aliás, estaria justamente aí a função extraordinária do campo, uma função precipuamente política, de marcar a mudança de um regime autoritário para um democrático. Embora o extraordinário não esteja, como destaca de Greiff, numa aplicação de um conceito particular de justiça, ele está sim na dimensão política que esta assume.

Jon Elster (2004), em seu livro Closing the books, tenta encontrar o que chama de "padrões recorrentes de comportamento" de diferentes experiências de justiça de transição, isto para evitar, dentro de um campo tão normativo como este, a construção de argumentos funcionalistas, procedimento que ele criticou fortemente em alguns de seus escritos anteriores (cf. Elster, 1989). Entretanto, o caminho adotado por ele acaba por se mostrar de difícil operação, ainda mais tendo em conta que Elster considera histórias da justiça de transição desde a Grécia Antiga. Não que de fato não tenha existido algo análogo à justiça de transição talvez até mesmo antes disso, mas também é fato que a internacionalização do direito positivo dos direitos humanos e a ascensão de tribunais internacionais com a relativização da soberania dos Estados (conceito, aliás, que nem existia propriamente na Antiguidade Clássica) indicam que os contornos que a justiça de transição ganhou no pós-guerra são bastante particulares e distintos de experiências anteriores, ainda que análogas. Além disso, o problema dessa metodologia empregada por Elster é que, ao estabelecer os aspectos normativos da justiça de transição de forma descritiva, isto é, tentado encontrar "padrões recorrentes" a fim de evitar a construção de argumentos funcionalistas, ele acaba por criar uma outra distorção, a de que a realidade parece não poder ter ocorrido de outra forma.

Um dos autores que assumiu uma tarefa mais aprofundada de realizar uma discussão acerca dos pressupostos teórico-normativos da justiça de transição e que possui alguns dos trabalhos mais interessantes neste sentido é Pablo de Greiff (2010 e 2012). Segundo ele, a justiça de transição englobaria dois objetivos mediatos: o reconhecimento e a confiança civil. E dois objetivos finais: a reconciliação e a democracia. Ele critica a visão de que a justiça de transição seria uma justiça "extraordinária", como uma forma distinta de justiça ou como mero compromisso.

O autor repõe a concepção tradicional acerca dos mecanismos centrais associados ao conceito e assume o empreendimento de tentar mostrar por que motivo eles precisam ser pensados como partes de um todo. Segundo ele, todos os mecanismos buscam o reconhecimento das vítimas, isto é, dar estatuto moral à condição das vítimas como seres 
humanos. ${ }^{14}$ Isso implica, além do reconhecimento tradicional da sua condição de sujeito, também reconhecer que os indivíduos podem ser objeto da ação de outros e que, neste sentido, podem ser feridos. Seria por isso que, muitas vezes, um dos pedidos mais importantes das vítimas nos processos justransicionais tende a ser o reconhecimento de que foram intencionalmente agredidas.

Em segundo lugar, e ainda mais importante, de Greiff (2012) destaca o reconhecimento de que as vítimas são sujeitos dos mesmos direitos e deveres que seus agressores e outros cidadãos, o que, afinal de contas, liga a condição humana e a responsabilidade mútua entre um e outro. É neste ponto - a questão da isonomia entre cidadãos - que, na minha opinião, falham muitas tentativas de relativização da importância da justiça criminal no interior do campo, enunciadas por autores como Lauro Swensson Júnior (2010), Dimitri Dimoulis (2010) e Thomas M. Scanlon (1999). Como sustentar do ponto de vista moral que um torturador da atualidade seja preso e um do passado não? Mais do que isso, na medida em que os objetivos mediatos e imediatos da justiça de transição estão relacionados entre si, como dar credibilidade à lei e às instituições judiciais numa situação em que ladrões de galinha, por exemplo, são condenados, ao passo que antigos torturadores ou genocidas não?

Com isto não pretendo relevar a importância de institutos como a prescrição e a anterioridade da lei (que em muitos destes casos acabam por obstruir a responsabilização criminal de agentes públicos envolvidos em graves violações aos direitos humanos), mas sim chamar a atenção para o princípio da isonomia, pouco aventado neste terreno e que tem função central tanto na construção da rule of law quanto da credibilidade social das instituições e no reconhecimento dos cidadãos como compartilhando o mesmo conjunto de direitos e deveres, sendo - nesta justa e exata medida - considerados como iguais, e podendo-se, assim, reconhecer-se como detentores de uma mesma condição humana.

Isto é particularmente importante porque uma das características centrais dos regimes autoritários que precederam a transição é justamente dividir a população em duas classes de cidadãos, os que estão acima das leis e os que sequer podem contar com sua efetividade quando for conveniente aos mandos e desmandos dos chefes de governo e das forças de segurança. Isto é, a questão da isonomia remete a um dos objetivos finais das políticas de justiça transicional, que é justamente contribuir para a construção da rule of law, com destaque aqui para seu elemento da igualdade perante normas fundamentais -

\footnotetext{
${ }^{14}$ Sobre a questão do reconhecimento, ver Honneth (1995).
} 
ainda que não escritas - de convivência. Se no passado foi justamente um processo de marginalização legal e/ou social que possibilitou que as violações físicas e psíquicas sofridas pelas vítimas acontecessem, é justamente aquela antiga divisão que, entre outras coisas, a justiça de transição deve procurar superar. E isto claramente envolve algumas vezes uma visada retrospectiva ou ex post facto da lei e da jurisprudência. ${ }^{15}$

A justiça de transição tem a função de institucionalizar o reconhecimento dos indivíduos como cidadãos com direitos iguais. Neste sentido, ainda que se referindo a outro contexto, de acordo com Jean Hampton (1995), a aplicação da justiça criminal tem particular importância porque consubstancializa a mensagem de que o agressor não é superior à vítima.

Comissões da Verdade têm certamente papel central neste terreno também na medida em que destacam com maior efetividade a diferença entre conhecimento e reconhecimento dos abusos do passado. Embora em geral elas não revelem fatos "desconhecidos", pelo menos por aqueles mais diretamente envolvidos de parte a parte na história de afirmação e oposição ao autoritarismo, elas promovem o reconhecimento do Estado de que aquelas violações aconteceram. Por esta via também se reconhece o valor das vítimas como seres humanos, que possuem sentimentos, dor, projetos etc. As reparações dão o reconhecimento material (cf. de Greiff, 2010, p. 44). Já a substituição em órgãos públicos de agentes antes envolvidos com violações aos direitos humanos por novos agentes tem a função de dar condições para que os cidadãos possam se remeter ao Estado futuramente como iguais.

O outro objetivo mediato que todos os mecanismos buscam, segundo de Greiff, é a confiança social nas instituições, algo que envolve o reconhecimento de que as regras, valores e normas constitutivas das instituições são vistos por seus membros ou participantes como vinculantes. A justiça criminal pode promover este objetivo ao reafirmar a relevância das normas fundamentais violadas. As instituições judiciais, particularmente quando antes envolvidas no aparato repressivo, podem alavancar sua confiabilidade se conseguem mostrar que ninguém está mais acima de direitos fundamentais. Já a implementação do direito à verdade pode redimir em alguma medida a história das vítimas, muitas vezes pessoas sobre as quais recaíam muitos estereótipos.

\footnotetext{
${ }^{15}$ Digo "algumas vezes" - e isto é importante - porque nem sempre é este o caso. Em muitos países, por exemplo, embora o crime de tortura não estivesse positivado durante os regimes autoritários, os demais crimes mais frequentes associados à repressão já eram positivados à época, como sequestro, homicídio, lesão corporal, estupro, atentado violento ao pudor, corrupção ativa e passiva, ameaça, calúnia, difamação, dentre outros.
} 
Outro problema que pode ser superado é a desconfiança bem fundada de que a identidade de muitos cidadãos ainda possa ser forjada em torno de valores que tornaram aquela violência possível. Por sua vez, as reparações também visam à confiabilidade social pela forma como demonstram a seriedade com que as violações passarão a ser tratadas pelo Estado.

Com relação aos objetivos finais (reconciliação e democracia), de Greiff sustenta que o ressentimento seria conceito útil para caracterizar uma sociedade não reconciliada. O ressentimento, em sua concepção, seria um tipo específico de raiva que elege um indivíduo ou grupo como responsável pela derrota das expectativas normativas de um sujeito. ${ }^{16}$ A sociedade não-reconciliada seria aquela em que os cidadãos nutrem este sentimento entre si e em relação às instituições. Suas expectativas baseadas em normas teriam sido derrotadas ou seriamente ameaçadas.

Compõe as funções do Estado moderno a garantia da segurança de seus cidadãos. Se o Estado é o próprio e primeiro responsável a violá-la, estimula o ressentimento. Isso intensifica a marginalização, também no período pós-transição, daqueles que sofreram perseguições, pois eles podem se sentir isolados em suas experiências de violação.

De certa forma, esta teorização apresentada por de Greiff conecta ressentimento com não-reconhecimento e, inversamente, reconciliação com reconhecimento. Pois, nesta medida, o ressentimento decorre justamente da falta de reconhecimento do sofrimento e das violações sofridas, que impedem que um indivíduo ou grupo se sinta parte de uma mesma sociedade, composta também por indivíduos que, em sua maioria, não sofreram as mesmas violações. Desta forma, inclusive, a reconciliação não assume necessariamente o sentido de um acerto entre agressores e vítimas, mas de uma justiça corretiva reconhecida pela sociedade e mediada pelo Estado.

Já com relação ao outro objetivo final da justiça de transição, a democracia, de Greiff (2012, p. 52) entende que as políticas públicas associadas ao campo não podem sozinhas promover a democracia. Em outras palavras, se se tomar a justiça de transição como variável independente para explicar a adoção do regime democrático por diferentes países, o resultado poderá ser decepcionante. Mesmo porque, em geral, as políticas de justiça transicional são adotadas depois do advento do regime democrático. Entretanto, vale dizer que a justiça de transição fortalece a rule of law ${ }^{17}$. E na medida em que rule of

\footnotetext{
${ }^{16} \mathrm{O}$ autor toma o conceito de ressentimento de Margaret Urban Walker (2006).

${ }^{17}$ Aqui tomada em seu sentido substantivo, que engloba também o formal, como veremos na próxima subseção.
} 
law e democracia são tidas como indissociáveis pela teoria política contemporânea, a justiça de transição ajudaria a fortalecer a democracia por esta via. ${ }^{18}$ Vários relatórios finais de comissões da verdade mencionam este aspecto. ${ }^{19}$

De um lado, a justiça criminal demonstra a generalidade da lei. De outro, a implementação do direito à verdade contribui para o esclarecimento sobre as formas pelas quais os sistemas legais falharam em proteger os cidadãos e assim oferece a base para o entendimento sobre como os sistemas devem agir no futuro. As reparações também contribuem para mostrar, mesmo ex post facto, que as normas fundamentais de convivência importam.

Aspectos formais da rule of law são centrais para a democracia, como a generalidade e a irretroatividade das leis. Isto porque a generalidade gera isonomia na medida em que impede a possibilidade de se individualizar regras. Já a irretroatividade das leis penais mais severas e daquelas que regulam a atividade da Administração Pública permite que cidadãos possam formular expectativas razoáveis sobre o que podem ou não fazer ou deixar de fazer. ${ }^{20}$ Isso também limita a arbitrariedade do poder, de modo que ele só poderá atuar segundo a lei e conforme a sua anterioridade em relação às decisões judiciais e atos administrativos.

Entretanto, de Greiff entende que um conceito eminentemente formalista da rule of law não é adequado para a justiça de transição. Isto porque, nos países em que ela começa a ter lugar, o aspecto formal da rule of law muitas vezes já está garantido. E, ainda mais importante, o aspecto formal da rule of law era garantido mesmo em boa parte (se não na maioria) dos regimes autoritários que precederam a transição. De acordo com o próprio Rawls (1971, p. 207), aliás, o aspecto formal da rule of law pode ser assegurado independentemente de outros critérios de justiça. E pode ser até mesmo compatível com a

\footnotetext{
${ }^{18} \mathrm{O}$ chamado neo-constitucionalismo estabelece uma visão ampliada da democracia, adicionando ao princípio majoritário o requisito de garantia da rule of law (Cf. Dahl, 1989; Maravall e Przeworski, 2003; Elster e Slagstad, 2003). Ainda que a partir de outro referencial teórico-normativo e metodológico, Habermas, por exemplo, dissolve as contradições entre direitos humanos e soberania popular a partir de uma argumentação que os coloca enquanto logicamente co-originários. Para ele (Cf. Habermas, 2003a, 2003c e 2004), os direitos humanos não competem com a soberania popular porque eles representam, na verdade, sua condição de possibilidade, isto é, são indispensáveis para a prática de uma formação pública, discursiva e pluralista da vontade.

${ }^{19}$ Por exemplo, as Comissões da Verdade e Reconciliação da África do Sul e do Peru, como veremos com mais detalhes também na próxima subseção (especialmente o caso sul-africano).

${ }^{20} \mathrm{Eu}$ me refiro a uma concepção limitada do princípio da irretroatividade da lei porque, mesmo em contextos não-transicionais, a lei pode retroagir em algumas situações, como no caso de favorecer réus e condenados quando da descriminalização de suas condutas, ainda que estas condutas tenham se dado antes de sua descriminalização. Neste sentido, no direito penal, por exemplo, só faz sentido em se falar do princípio da irretroatividade da lei em relação a uma legislação penal que tipifica novos crimes ou que aumenta a severidade de seu enforcement, seja na dosagem da pena ou em outros aspectos.
} 
injustiça. De Greiff (2012, p. 56) afirma neste sentido que aqueles que estão preocupados com a questão da justiça e não apenas da estabilidade e da ordem têm razões para adotar um conceito mais robusto e substantivo de rule of law do que um que remeta unicamente à imparcialidade e à regularidade.

De Greiff tem em mente uma concepção de rule of law que envolva participação política. De acordo com ele, nenhuma outra forma de governo oferece garantias para a proteção dos direitos humanos como a democracia, nem mesmo o despotismo esclarecido, que, quando convém, pode se servir mais do seu lado despótico do que do esclarecido. Esta concepção do autor vai de encontro com elaborações contemporâneas da Teoria Crítica, especialmente Rainer Forst (2011), segundo o qual, para se designar uma norma como justa ou injusta não basta avaliar seu conteúdo, mas é preciso avaliar também a forma como foi elaborada.

Os cidadãos somente podem entender as normas como direitos na medida em que contribuem (direta ou indiretamente) para sua elaboração. Caso contrário, uma norma não será exatamente vista como um direito, mas como um benefício ou algo do tipo atribuído ao sujeito por uma autoridade que não guarda com ele uma relação de accountability vertical. Por isso, a rule of law só faz plenamente sentido como uma garantia do indivíduo perante o Estado quando este Estado é dirigido por um regime de governo democrático. Da mesma forma, como mostra Habermas (1998b), os indivíduos somente podem exercer seus direitos políticos livremente se têm garantidos direitos civis básicos. A democracia é em boa medida tanto uma condição como uma consequência de esforços institucionalizados para se estabelecer justiça.

Segundo de Greiff, a justiça de transição pode promover a democracia por meio do fortalecimento de organizações da sociedade civil e por meio da rule of law. Outro autor que se preocupa com a incorporação de uma visão mais sensível à democracia em um terreno tão normativo como a justiça de transição é Raphael Neves. Em sua tese de doutorado (Neves, 2014, p. 51), o autor afirma que, se a exigência da responsabilização de violadores dos direitos humanos está no núcleo normativo da justiça de transição, a decisão sobre se e como aplicar punições pode ser uma questão resolvida pela deliberação democrática.

Enquanto que a responsabilização é moral, por isso cogente, universal, as atenuantes, agravantes e excludentes de punibilidade seriam questões éticas, que estão no horizonte de expectativas e desejos de uma comunidade. Se a um juiz cabe decidir a respeito da culpabilidade (que remete a um critério universal de justiça), a lei dá os 
contornos do que deve ser feito com o agente levando-se em conta a valorização social do bem jurídico violado (determinada em geral pela amplitude entre pena máxima e mínima na lei), a gravidade da ação, suas circunstâncias e características do próprio agente. Tudo isso são questões éticas ${ }^{21}$, pois dependem da comunidade eleger os elementos que vão ou não ser relevantes para influenciar na dosagem da pena ou mesmo na sua aplicação ou não. Já a culpabilidade não seria uma questão que devesse ser deliberada democraticamente.

Para Neves (2014, p. 53-55), a Comissão da Verdade e Reconciliação da África do Sul tinha justamente esta característica: sem negar a culpabilidade dos agentes (que eram considerados responsáveis pelo que fizeram), inseriu-se na dimensão ética da questão criminal, em que o horizonte de expectativas da comunidade pode influenciar a aplicação ou não das penas.

Neste sentido, Neves (2014, p. 80) afirma que, se hoje qualquer pessoa pode ser processada em uma Corte internacional por conta do princípio da jurisdição universal, então as normas internacionais e instituições têm uma tarefa extra de legitimação de sua atuação. Caso contrário, o direito internacional pode se colocar como uma mera aplicação top-down de sanções, deixando os direitos humanos vulneráveis a acusações de uma forma colonialista de dominação. $\mathrm{O}$ autor considera que transições legítimas são aquelas que contaram com anistias pós-soberanas e que suspenderam apenas a punição, mas não a accountability. ${ }^{22}$

Ainda sobre a questão da democracia, os autores Mcevoy e Mcgragor (2008) advogam por uma justiça de transição com maior participação da sociedade civil, pois, na maioria das experiências, ela tem sido amplamente dominada por políticas de Estado e de governo com baixo índice de participação. Na visão destes e outros autores, como RohtArriaza (2006), experiências de nível local, como as gacaca em Ruanda e os comitês de bairros no Uruguai dão mais legitimidade ao processo e mais sentido ao objetivo de reconciliação.

De forma parecida, Ellen Lutz (2006, p. 333) entende que os casos explorados no livro organizado por Roht-Arriaza e Mariezcurrena (2006) mostram que os mecanismos de justiça de transição, para serem efetivos, devem ser tanto contextualmente quanto

\footnotetext{
${ }^{21}$ As quais, no universo semântico habermasiano, distinguem-se das questões morais. Enquanto a ética diz respeito ao bem comum, isto é, a um horizonte de objetivos desejáveis a partir de um contexto social específico, a moral diz respeito ao núcleo da justiça, e tem valor universal (Cf. Habermas, 2003b).

${ }^{22}$ Mas importa destacar que Neves $(2014$, p. 94) também entende que haveria um limite para o Estado conceder anistias, pois há condutas que são injustificáveis do ponto de vista moral.
} 
culturalmente apropriados. Intervenções no Iraque $\mathrm{e}$ no Afeganistão, com $\mathrm{o}$ estabelecimento de um sistema judicial em boa medida heterônomo em relação ao contexto e à cultura existentes, levaram a experiências decepcionantes na promoção de um entendimento compartilhado de justiça a respeito das decisões aplicadas (Cf. Stover, Megally e Mufti, 2006). Pode não haver um reconhecimento público das violações cometidas no passado se não há um corpo político representativo capaz de implementar as políticas necessárias. De outra parte, também o contexto é importante: se há ameaças concretas de retaliação, os processos de revelação da verdade ficam seriamente comprometidos. Às vezes, verdade e justiça precisam esperar: o timing das políticas, sugere Lutz (2006), também é ponto muito sensível.

As gacaca em Ruanda são bom exemplo de tentativa culturalmente aceita para a questão da justiça. Estas instituições, que faziam uma mescla entre uma função de atribuição de responsabilidades e elucidação da verdade, ergueram-se tanto como uma forma de justiça quanto de reconciliação. O sistema judicial em Ruanda era amplamente visto como descolado dos anseios das comunidades que mais sofreram com as atrocidades. Por outro lado, as gacacas também foram influenciadas em seu funcionamento por noções da legislação internacional humanitária e de direitos humanos (Cf. Longman, 2006).

Nas palavras de Ellen Lutz (2006, p. 335): “iniciativas no nível local forçam ativistas e financiadores internacionais a pensarem de modo mais nuançado sobre o papel das Cortes formais e dos sistemas legais ocidentais e a incorporarem este novo entendimento em funcionamento na interseção entre justiça de transição e rule of law". ${ }^{23}$ Os processos conduzidos organicamente a partir de uma lógica de demandas e aspirações sociais internas são os que galgam maior legitimidade, como os processos no Peru e na Argentina. Nestes países, a popularidade das políticas de justiça transicional foi tão grande que passou a ser bastante difícil até mesmo criticá-las. Já processos construídos quase que inteiramente a partir de fora encaram problemas de legitimidade e mesmo de continuidade. "A lição parece ser a de que a sociedade civil pode manter vivo o tema da
accountability, mas é preciso haver certo nível de vontade política do governo
para que se avance decisivamente, como os exemplos da Argentina com a
ascensão do Presidente Néstor Kirchner, o Chade e o Timor Leste
exemplificam. Além disso, se a transformação da sociedade é limitada, como

\footnotetext{
${ }^{23}$ No original: "local-level initiatives force international advocates and funders to think in a more nuanced way about the role of formal courts and Western style legal systems, and to incorporate that new understanding into work at the intersection of transitional justice and rule of law".
} 
aponta Schabas, a justiça de transição também será limitada" (Lutz, 2006, p. $339-338){ }^{24}$

Outra lição, segundo a autora, seria que, mesmo quando fatores e instituições externas intervêm, é preciso que de alguma forma os processos sejam comandados internamente, a partir de uma lógica própria daquela sociedade e cultura.

De volta às considerações teórico-normativas elaboradas por de Greiff, é importante destacar que, embora o autor tenha contribuído para um importante desenvolvimento teórico-normativo do campo (chamando atenção, inclusive, para a necessidade de se conectar questões normativas a participação política), em alguma medida, seu texto também padece de um problema próximo ao que ele mesmo aponta em Ruti Teitel. Ao caracterizar a justiça de transição como um campo que se encontra no que ele caracterizou como um "mundo muito imperfeito", um mundo caracterizado não só pela violação das normas, mas também pelo fato de haver um imenso e previsível custo associado ao esforço de enforcement das normas básicas de convivência, aproxima-se do problema da "transição". Ainda que o conceito de "mundo muito imperfeito" não equivalha ao de transição tal como elaborado por Teitel, tem com ele muitos paralelos, especialmente no que diz respeito à situação precária em que as demandas por verdade e justiça precisam ser veiculadas.

Como assevera Renan Quinalha (2012, p. 91), este tipo de contextualização da justiça de transição em situações não ideais de democracia e justiça tem levado a um esgarçamento excessivo da compreensão do que significa e até onde vai a transição. Isto porque, na verdade, o campo - já faz um bom tempo - tem se aplicado a situações muito diversas, muitas das quais dificilmente seria possível classificar como transicionais. É o caso, por exemplo, da maioria dos países latino-americanos hoje, que são considerados democracias consolidadas há anos, mas ainda adotam políticas de justiça "transicional". Por este motivo que alguns trabalhos mais recentes têm se engajado na tentativa de formular conceitos mais abrangentes sobre o campo, de modo a englobar também políticas realizadas em democracias já consolidadas. ${ }^{25}$

\footnotetext{
${ }^{24}$ No original: "The lesson seems to be that civil society can keep the issue of accountability alive, but it takes a certain level of government political will to decisively move forward, as the exemples of Argentina with the ascent of President Kirchner, Chad, and East Timor illustrate. Furthermore, if the transformation of society is limited, as Schabas points out, transitional justice will also be limited".

${ }^{25}$ É o caso, por exemplo, de paper apresentado por Vello Petai e Eva-Clarita Petai na General Conference do European Consortium for Political Research, realizado entre os dias 3 e 6 de setembro de 2014 em Glasgow, Escócia. O paper, intitulado "Transitional and Retrospective Justice: Conceptual Differentiation and Comparative Application", procura diferenciar "justiça de transição" de "justiça retrospectiva",
} 
Mesmo assim, de Greiff apresenta uma (importante e necessária) justificação para a afirmação de que os mecanismos da justiça de transição são parte de um todo, afirmação esta bastante repetida pela literatura, mas fraca e raramente apoiada em esforços de justificação. De acordo com ele (de Greiff, 2012, p. 32-33), a tendência de se forçar uma visão de trade off entre os mecanismos do campo é inapropriada.

Cada vez mais, as funções de cada mecanismo têm se interpenetrado. A Comissão da Verdade e Reconciliação do Peru, por exemplo, contou durante seus trabalhos com um grupo especial cuja função era compilar e organizar provas de crimes que poderiam ser utilizadas em processos judiciais (Cf. Roht-Arriaza, 2006). Entretanto, no Peru, havia absoluta falta de coordenação entre a Comissão da Verdade e Reconciliação e o Ministério Público. As instâncias concorriam nas investigações e não souberam dividir o trabalho. Membros do Ministério Público chegaram a não aceitar muitas das evidências reunidas pela Comissão e mesmo a promoverem denúncias frívolas contra alguns de seus membros. A pior consequência desta falta de articulação, segundo Cueva (2006), foi o prejuízo do processo de accountability.

Em Marrocos, de 1999 a 2001, a Instance Indépendante d'Arbitrage atuou como uma instituição de reparação individual. Ouviu testemunhos de aproximadamente 8 mil pessoas e tomou mais de 5 mil decisões, concedendo indenizações para mais de 3 mil pessoas. Em janeiro de 2006, a Instance Équité et Réconciliation tornou público seu relatório, inclusive sobre as decisões acerca de reparações. Houve uma transição sem propriamente mudança de regime que ligou a revelação da verdade a reparações de forma muito próxima. Ao contrário da primeira instituição, a Instance Équité também ofereceu benefícios de saúde e reparações coletivas. Esta última comissão também foi essencial para indicar reformas institucionais no país (Cf. Lutz, 2006).

Estas experiências mostram como é importante articular os mecanismos da justiça de transição. A revelação da verdade, por exemplo, ganha mais sentido se há um objetivo de reparação ou retribuição associado a ela. Isto porque a revelação sobre os fatos e circunstâncias das violações do passado perde força em sua função de redimir o passado das vítimas se não é acompanhada de reparações. E vice-versa, a adoção de reparações sem a revelação da verdade pode parecer um esforço do governo de comprar a

conforme se trate de uma situação de transição ou de democracias consolidas (ou, neste caso, também de situações em que não houve mudança de regimes). O paper foi circulado apenas entre os integrantes do painel, mas o abstract pode ser encontrado no seguinte link: http://ecpr.eu/Events/PaperDetails.aspx?PaperID=21461\&EventID=14. 
benevolência das vítimas. Ainda, condenações sem reparação das vítimas oferecem a ideia de uma compensação apenas como "vingança" (Cf. de Greiff, 2012). ${ }^{26}$

Neste sentido, o texto de de Greiff ajuda a entender por que a aplicação seletiva de mecanismos é uma política de certa forma desorientada. Isso não significa que medidas isoladas não sejam positivas, mas que deve haver uma pressuposição normativa em favor de sua implementação coordenada. Poucos estudos quantitativos e qualitativos foram realizados sobre o tema da implementação dos direitos ligados à justiça de transição, em boa parte em função da dificuldade de se isolar variáveis para explicar "impacto" na área. Dos poucos estudos quantitativos que existem, o mais importante foi realizado por Tricia Olsen, Leigh Payne e Andrew G. Reiter (2010). Para estes autores, também parece importar a combinação entre os mecanismos da justiça de transição para que as políticas tenham efeito positivo sobre a democracia e os direitos humanos. Os autores sustentam, por exemplo, que comissões da verdade implementadas sem outras iniciativas parecem ter impacto negativo sobre os direitos humanos e sobre a democracia, mas positivo quando combinadas com julgamentos e outras medidas. Neste sentido, os autores corroboram a abordagem holística do campo.

\section{2) Evolução do campo nas últimas décadas}

Nos próximos tópicos, veremos o desenvolvimento da jurisprudência, da normativa internacional e do debate teórico relacionado ao campo da justiça de transição em relação a seus elementos mais importantes, a justiça, a verdade e as reparações. $O$ quarto elemento usualmente citado a compor o campo, a reforma das instituições, permeará a discussão em todos estes tópicos.

\subsection{1) Justiça}

Em Justice Cascade, Kathryn Sikkink (2011) reconstrói o desenvolvimento das normas e entendimentos jurisprudenciais a respeito da responsabilidade de agentes estatais envolvidos em graves violações aos direitos humanos. Este movimento rompe com a visão assentada por séculos sobre soberania estatal e imunidade de chefes de Estado. Antes dos

\footnotetext{
${ }^{26}$ Mais sobre a coerência interna e externa (vistos como parte de um todo) dos mecanismos da justiça de transição, cf. em Cueva (sem data).
} 
novos paradigmas erigidos por este desenvolvimento, os Estados respondiam como um todo por violações praticadas por seus agentes e desta responsabilização "institucional" (e não individualizada) emergia o dever de indenizar.

Em estudos mais recentes, Sikkink procurou mostrar com Walling (2010) que algumas das intuições amplamente difundidas a respeito da justiça criminal no âmbito da justiça de transição não tinham base empírica. Para elas, não é possível afirmar que os julgamentos prejudicam a estabilidade democrática, nem que eles ocorram preferencialmente no momento da transição (como advogava Huntington, 1991). ${ }^{27}$ Elas também apontam para inúmeras experiências em que justiça e verdade não se apresentaram numa relação de trade off.

Por outro lado, segundo Mamdani (2010, p. 54), o modelo westfaliano é ainda a moeda corrente no sistema internacional. Os conceitos de soberania e cidadania continuam a estar intimamente entrelaçados, pois ainda é o Estado que torna efetivos os direitos básicos dos cidadãos. A ordem humanitária internacional, em contraste, não é um sistema que reconhece a cidadania, o que prejudica a construção de uma ponte com a linguagem dos direitos dos cidadãos. Mesmo assim, a evolução dos direitos humanos e do direito humanitário tem sido acompanhada de mecanismos nacionais e internacionais para o julgamento de genocídios, crimes de guerra e crimes contra a humanidade.

Por exemplo, com a Convenção Contra a Tortura, de 1984, foi dado importante passo normativo rumo à desterritorialização das jurisdições nacionais e à jurisdição internacional (Cf. Orentlicher, 2004, 1088). Os signatários da Convenção se submetem ao dever de julgar e punir torturadores, ainda que as torturas não tenham sido praticadas em seus países.

Outros passos importantes no sentido do dever de punir foram dados pela Convenção Americana de Direitos Humanos (CADH) e pelas Convenções Europeias para a Proteção aos Direitos Humanos e Liberdades Fundamentais. A propósito de justificar a necessidade de punição para os crimes previstos nesta normativa internacional, Orentlicher (2004) afirma que os julgamentos fazem as sociedades reavaliarem seus valores básicos, isto é, reafirmarem o respeito à rule of law e à dignidade dos indivíduos, a mais segura garantia contra futuras repressões.

A justiça de transição argentina pode ser caracterizada como um caso paradigmático de aplicação e extensão da justiça criminal (Cf. Neves, 2014). Em 1983,

\footnotetext{
${ }^{27}$ Segundo Huntington, se fosse para fazê-los, que se os fizesse o quanto antes.
} 
envolta em crise sócio-econômica e sem credibilidade por conta da fragorosa derrota na Guerra das Malvinas, a Junta Militar argentina editou a Lei de Pacificação Nacional, conferindo auto-anistia aos agentes da repressão pouco antes da retomada das eleições democráticas. Os militares também emitiram um documento justificando seus atos, o "Documento Final sobre a Guerra contra a Subversão e o Terrorismo".

Raúl Alfonsín, candidato opositor ao grupo peronista, prometeu promover o julgamento e condenação de militares que violaram direitos humanos, assim como membros de guerrilhas, especialmente os que cometeram os piores excessos de cada lado. Alfonsín delineou os contornos do que ficaria conhecido como a "teoria dos dois demônios", segundo a qual o país sofria tanto com a extrema direita quanto com a extrema esquerda.

A princípio, a meta era processar o terrorismo revolucionário e o terrorismo de Estado. Uma vez eleito, o governo Alfonsín aprovou no Congresso uma lei, de dezembro de 1983, que anulava a auto-anistia dos militares. A votação da lei contou com o apoio de 208 votos a dois na Câmara e aprovação unânime no Senado. Foi a primeira lei aprovada no Congresso argentino em oito anos. Houve pouca resistência dos militares, que estavam desmoralizados. Mas depois de publicada a lei, o governo resolveu não se envolver com o processamento dos perpetradores, no que foi muito criticado por vários grupos, especialmente as Mães e Avós da Praça de Maio (Cf. Neves, 2014, p. 20 e seguintes).

Ao fim dos processos, em 1985, dos nove comandantes militares julgados, cinco foram condenados e quatro absolvidos. Um ano depois, a Suprema Corte manteve as absolvições e reduziu as penas de dois dos condenados. Alfonsín acreditava que as investigações e processos deveriam recair preferencialmente sobre os detentores de posições de comando e deveriam ser rápidos, para evitar maiores conflitos sociais.

Se historicamente o discurso sobre direitos humanos esteve associado à abolição de penas e/ou garantias para um julgamento justo, com a emergência da justiça de transição, o discurso dos direitos humanos passou a ser associado também ao dever de punição, neste caso, de quem violou garantias e direitos fundamentais. ${ }^{28}$

\footnotetext{
${ }^{28}$ Vale destacar, contudo, que, apesar de associarmos usualmente sanção criminal com encarceramento, a verdade é que as formas de punição podem variar bastante, da perda temporária de direitos (como o direito à eleição para cargos políticos ou de viajar para o exterior), passando pela exoneração de cargos públicos, até se chegar (dependendo do país e do contexto histórico) à pena de morte.
} 
Em uma definição bastante enxuta do conceito, vale dizer que rule of law ${ }^{29}$ implica que todos os cidadãos de um país estão igualmente submetidos à força da lei, sem distinções. O conceito indica também que, além de igual para todos, a lei é efetivamente cumprida ou pelo menos passível de enforcement efetivo. Além disso, a rule of law indica que as normas de convivência emanadas do Estado não podem retroagir a atos e omissões anteriores à sua entrada em vigor, e também são gerais e abstratas, isto é, não podem ser formuladas para favorecer uma ou outra pessoa determinada. ${ }^{30}$ Estes são os contornos de uma visão formalista da rule of law. Os partidários de uma visão substantiva agregam aos elementos citados acima um conjunto de direitos fundamentais e princípios gerais de direito que devem ser observados por qualquer Estado que busque a consolidação da rule of law. ${ }^{31}$

O maior dilema para as políticas de justiça transicional é definir o papel da justiça neste contexto. Seja em momentos de transição ou pós-transicionais (de democracias já consolidadas), a concepção de justiça associada ao campo se entrincheira entre visões retrospectivas e prospectivas. Nestes períodos, a rule of law é mais um programa, que visa a estabelecer um novo paradigma, uma vez que muitas das injustiças do passado foram cometidas com a licença da lei (Cf. Teitel, 2000, p. 11).

Levar o regime anterior a julgamento traz conflitos entre concepções positivistas e jusnaturalistas do direito e entre concepções formalistas e substantivistas da rule of law. Para explorar estes conflitos, Teitel (2000) se reporta ao conhecido debate jurisprudencial nos EUA entre Lon Fuller e H.L.A. Hart, sobre a ideia de justiça depois da experiência do nazismo. A questão central era saber se se podia fiar em leis nazistas evocadas pela defesa para se decidir sobre o processo de colaboradores do regime. ${ }^{32}$

Em posição juspositivista, Hart sustentava a necessidade da continuidade das leis para restabelecer a crença na regularidade procedimental que teria sido afetada no regime

\footnotetext{
${ }^{29}$ Preferi manter o termo em inglês porque não há uma tradução precisa para o português. Usualmente, o termo é traduzido como "império da lei" ou "Estado de Direito". A primeira tradução não dá em português a dimensão da densidade e abrangência teórica que o conceito assume na literatura internacional. Já a segunda corresponde a uma metonímia, valendo-se do todo, o Estado de Direito, para designar seu elemento principal, a rule of law.

${ }^{30}$ As políticas de ação afirmativa, por exemplo, também têm o caráter geral e abstrato da lei, pois, apesar de favorecerem grupos sociais para corrigir desequilíbrios, elas não se destinam a pessoas específicas, mas a qualquer um que se enquadre nos qualificativos determinados pela lei.

${ }^{31}$ Para uma reconstituição do debate entre formalistas e substantivistas, ver Paul Craig (1997).

${ }^{32}$ Ver Hart (1958) e Fuller (1958).
} 
anterior. O meta-valor da rule of law, neste sentido, seria o devido processo legal, entendido como regularidade nos procedimentos e adesão à lei estabelecida. Para os juspositivistas, o direito deve se proteger da política, e isso só acontece quando a rule of law tem uma legitimidade independente dos rumos da política.

Já para Fuller, dar sentido à rule of law significava romper com o regime nazista legal anterior. A Alemanha precisava restaurar o respeito pela lei e pela justiça. Segundo o entendimento deste autor, as normas do regime nazista não eram sequer leis, pois não dispunham de uma série de requisitos procedimentais em sua edição para serem consideradas como tais de forma legítima.

De certo modo, se parte das arbitrariedades é respaldada pela lei no regime precedente, em alguma medida, a imposição da nova lei democrática exigirá a desconsideração de boa parte das leis precedentes. Jusnaturalistas como Fuller destacam o papel transformador do direito na mudança para um regime mais liberal, e esta tem sido a tônica tanto da legislação internacional sobre justiça de transição quanto da jurisprudência de Cortes nacionais e internacionais sobre o assunto, especialmente no que diz respeito ao impedimento da aplicação de excludentes de culpabilidade (tais como a irretroatividade da lei penal mais severa) para afastar a possibilidade de processo e julgamento dos crimes contra a humanidade.

\section{Justiça retrospectiva e sanções limitadas}

Os julgamentos realizados nas transições ou mais tarde são concebidos de forma a traçar uma linha divisória entre liberdade e repressão, resistência e colaboracionismo. Há, neste contexto, muito de elaboração ex-post facto, de modo que as definições elaboradas no presente (como traição, crimes de guerra etc) são uma visão do presente se projetando para o futuro, mas que exercem um juízo de apreciação sobre o passado.

Para superar questões como a irretroatividade da lei penal e a prescrição em casos de crimes particularmente hediondos, a legislação internacional dos direitos humanos tem sido incorporada a legislações domésticas. Na Hungria, por exemplo, uma tentativa de revogar a lei que isentava os agentes públicos envolvidos com a violenta repressão sobre a revolução de 1956 foi considerada inconstitucional por ser uma investida ex post facto. Mas foram feitas exceções para os crimes mais sérios, como os crimes de guerra.

Algo parecido ocorreu na Polônia. Nos anos 1990, oficiais e mesmo o antigo ministro da segurança pública foram processados por crimes que praticaram entre 1946 e 
1952 envolvendo torturas e mortes de prisioneiros políticos no país. Por conta da distância no tempo, as persecuções criminais precisaram de revogações parlamentares sobre regras de prescrição e decadência em determinados casos (Cf. Teitel, 2000, p. 44-46).

$\mathrm{Na}$ República Checa, as regras de prescrição e decadência foram consideradas como normas procedimentais, de direito processual, não material, e puderam ser levantadas, abrindo a porta para processos contra o chefe do Partido Comunista, o chefe de segurança e o ministro do interior e seu representante geral pela repressão brutal às manifestações de 1988 e $1989 .{ }^{33}$ A maioria deles foi condenada, inclusive o chefe do Partido Comunista, Miroslav Stepan. Na Rússia, um dos poucos processos foram realizados contra os perpetradores do putsch de 1991. Neste caso, porém, o único processo que realmente vingou terminou em absolvição do acusado (Cf. idem ibid.).

Apesar do crescimento exponencial da responsabilidade criminal em abstrato na legislação internacional e mesmo do número de acusações, as persecuções criminais não têm levado necessariamente a punições. Na justiça de transição, as fases de atribuição de culpa e de atribuição de penalidades são mais demarcadamente diferenciadas. A sanção criminal pode ficar restrita à investigação que atribui responsabilidades.

Com relação aos julgamentos sobre a Segunda Guerra Mundial, entre 1946 e 1958 começou um processo de revisões e clemências que culminou na comutação massiva de condenações de criminosos de guerra do nazismo. Além disso, dentre os milhares de casos julgados entre 1955 e 1969 na Alemanha, menos de 100 dos condenados tiveram atribuída a pena de prisão perpétua e menos de 300 outras penas menores foram aplicadas. Anos depois, algo parecido ocorreu nas transições do Sul da Europa. Na Grécia, muitas das penas aplicadas a princípio foram depois suspensas ou comutadas (Cf. Teitel, 2000, p. 47). O governo entendeu que os processos e os julgamentos tinham surtido seu efeito de responsabilização e que, no final, era preciso assumir a responsabilidade política.

Anistias se tornaram a regra ao longo do continente latino-americano, desde o Chile, passando por Nicarágua e El Salvador e muitos outros países. E a história se repete na Europa Oriental, onde foram adotadas suspensões de punições para soldados de fronteira da antiga Alemanha Oriental, bem como na República Checa. Na Romênia, líderes comunistas e policiais condenados pelos massacres de 1989 foram soltos como resultado de sua condição de saúde ou por perdões presidenciais.

\footnotetext{
${ }^{33}$ Prescrição e decadência são consideradas no Brasil como temas de direito material.
} 
Apesar do recente furor das tentativas de aplicação de sanções penais, as punições limitadas têm ressurgido como a regra de muitos processos. De acordo com Priscilla Hayner (2011), as sanções penais têm sido limitadas também nas Cortes internacionais, onde ainda há um número relativamente pequeno de pessoas julgadas e condenadas.

\section{Responsabilidade individual}

Com julgamentos do alto escalão de governos ou de juntas militares, como os ocorridos no pós-guerra na Europa e na Argentina durante a transição, surge a questão da individualização da pena, outro princípio fundamental do direito penal, em alguma medida também relativizado por estes processos.

Como conceituar a responsabilidade de uma cúpula da liderança política? A Corte de Ulm enfrentou esta questão em julgamento sobre um massacre de milhares de pessoas na fronteira da Lituânia durante a Segunda Guerra. Hitler e seu círculo imediato foram tidos como os "perpetradores-chefe" das medidas de aniquilação, enquanto que os réus do caso foram considerados como meros "cúmplices".

Dilema parecido, sobre como conceituar a responsabilidade legal de comandantes e seus subordinados por brutalidades coordenadas pelo Estado, foi enfrentado na Argentina. Esta foi a questão central no julgamento da Junta Militar na transição. Neste contexto, foi desenvolvida uma "teoria da coautoria" (Cf. Teitel, 2000). Segundo esta teoria, a responsabilidade dos superiores e dos subordinados se equivale. Os comandantes militares argentinos foram responsabilizados por seu papel em planejar e ordenar a tortura e desaparecimento de milhares de pessoas na qualidade de "perpetradores indiretos". Mas a teoria da coautoria foi modificada mais tarde, em decisão dividida, pela Suprema Corte, que passou a considerar os comandantes como cúmplices. ${ }^{34}$

Mesmo assim, a acusação com base na teoria da coautoria levou a uma série de defesas baseadas na "obediência devida", para atenuar ou mesmo levantar a responsabilidade dos agentes diretamente envolvidos em atos de repressão, mas que justificavam suas condutas por terem "cumprido ordens". Essa visão se mostrou vitoriosa nos anos 1980 e 1990, sendo condenados apenas os agentes que teriam claramente "excedido" as ordens em seus atos.

\footnotetext{
${ }^{34}$ A propósito de vinculá-los à prática dos crimes hediondos, a Justiça argentina passou a condenar os militares da Junta por "negligência grosseira" (Cf. Teitel, 2000, p. 55).
} 
Como já mencionado, enquanto, no direito comum, as sanções criminais têm foco na estabilidade, previsibilidade e segurança jurídicas, e enquanto usualmente ligamos a rule of law à estabilidade, na justiça de transição, as sanções criminais enfatizam uma mudança normativa. O distanciamento em relação ao regime anterior é marcado pelas práticas de punição. Mas elas também oferecem uma solução para outro problema central: a atribuição de responsabilidade individual por violações sistemáticas cometidas sob autoritarismo, em oposição à atribuição de culpa coletiva que muitas vezes toma lugar a propósito da expiação de responsabilidades individuais. ${ }^{35}$

A função transformativa da justiça também está em reconhecer as violações e estigmatizá-las como moralmente erradas e contrárias ao tipo de sociedade que se quer construir. Estes aspectos, em processos mais limitados, também podem se efetivar, pelo menos parcialmente, por meio de ações na esfera civil.

Apesar de os processos serem encarados como uma representação histórica inadequada em função de sua abordagem individual da accountability, sendo que a perseguição política moderna certamente transcende a esfera individual, a justiça de transição contemporânea faz a mediação de antinomias entre indivíduo e coletividade. Segundo Teitel (2000, p. 55), nos casos bem sucedidos, a construção histórica nos meios legais produz uma visão matizada da responsabilidade: tida como individual, mas conformada por um contexto repressivo.

Uma vez que o processo individualiza as responsabilidades, a sociedade se redime. Esta individualização levanta a culpa coletiva do regime anterior e relegitima a autoridade do Estado. Para Teitel (2000, p. 67), ao se isolar as violações reprováveis da política do passado e ao se individualizar os agressores, libera-se o regime sucessor do peso das atrocidades do passado.

Do ponto de vista jurídico, a aplicação de punições brandas ou simbólicas tem sido a resposta prática para vários dos dilemas da justiça criminal no bojo da justiça de transição, tais como a responsabilidade individual versus coletiva e a questão do afastamento de alguns dos elementos centrais do aspecto formal da rule of law para se abrir o flanco para as sanções penais. Em outras palavras, para contrabalançar a superação de princípios caros à própria rule of law, como a irretroatividade da lei penal mais severa,

\footnotetext{
${ }^{35}$ Segundo Hannah Arendt, em "Responsabilidade pessoal sob ditadura", a "culpa coletiva", na medida em que condena toda a sociedade, tende a dar a impressão de uma isenção de responsabilidade pessoal dos sujeitos em seu envolvimento com a repressão. Afinal, "quando todos são culpados, ninguém o é" (Arendt, 2004, p. 83).
} 
muitas vezes a responsabilização criminal é acompanhada por punições brandas, imbuindo o processo mais de um caráter simbólico do que eminentemente retributivo.

\section{Justiça Política}

No contexto da justiça de transição, Jon Elster (2004) distingue justiça legal, justiça administrativa e justiça política. Segundo ele, a justiça legal possui dois aspectos essenciais: adesão ao devido processo legal e incerteza do resultado, além de quatro características essenciais. Primeiro, a legislação aplicável tem que ser o menos ambígua possível, para reduzir a margem para a interpretação judicial. Segundo, o Judiciário precisa ser independente, isto é, estar isolado o máximo possível em relação às pressões e constrangimentos políticos. Em terceiro lugar, é necessário haver isenção dos juízes e jurados em relação à interpretação da lei. Em alguns casos, a falta de isenção pode produzir penas excessivamente severas. Em outros, leniência excessiva (um exemplo são os juízes nazistas que julgaram criminosos do nacional-socialismo imediatamente depois da guerra). Por fim, Elster afirma que é necessário que haja adesão aos princípios do devido processo legal: audiências públicas contenciosas, direito de escolher o próprio advogado, direito de apelação, irretroatividade da lei penal mais severa, respeito a prescrições e decadências, individualização da pena e da culpabilidade, presunção de inocência, ampla defesa, dentre outros elementos. Quanto mais próximo de atender a estes quatro requisitos, mais próximo um julgamento estaria de uma justiça puramente legal.

Já na justiça política, o Executivo decide o que fazer com os agressores diretamente ou após serem considerados culpados pelo Judiciário ou outra instância. Um exemplo seria a decisão dos aliados de exilar Napoleão na ilha de Santa Helena, no século XIX (Elster, 2004, p. 85). Elster também se refere a decisões de execuções ao fim da Segunda Guerra, caracterizadas por ele como "show trials". Mas em Nuremberg, apesar do esforço dos soviéticos, os julgamentos teriam se aproximado mais de uma justiça legal, algo que seria corroborado pela incerteza do resultado dos julgamentos, uma vez que três dos 23 acusados foram absolvidos. Já o Tribunal de Tóquio configuraria o conjunto de julgamentos que mais teria se aproximado de uma justiça puramente política. ${ }^{36}$

Elster entende que as exigências da justiça puramente legal são rotineiramente desafiadas na justiça de transição, às vezes por boas razões, outras vezes não. Em

\footnotetext{
${ }^{36} \mathrm{~A}$ justiça administrativa estaria em uma posição intermediária entre a justiça legal e a justiça política e corresponderia à prática de processos administrativos.
} 
sociedades bem reguladas e próximas de um ideal de Estado de Direito, a violação a estes princípios numa justiça ordinária é rara. Mas as transições e as exigências de acerto de contas com um passado de violações conformariam as circunstâncias excepcionais em que alguns destes princípios são desrespeitados. Se há abuso neste desrespeito, a justiça legal se degenera em justiça política. Segundo Elster (2004, p. 91), isso acontece quando um observador pode prever o resultado dos julgamentos com total certeza.

No entendimento de Teitel (2000, p. 75 e seguintes), a justiça política tende a aparecer quando se tem uma política de punição levada adiante principalmente para elaborar uma memória histórica já previamente conformada. Exemplos neste sentido seriam os julgamentos realizados no leste europeu depois do colapso da cortina de ferro. Muitos destes julgamentos teriam sacrificado uma série de direitos individuais para estabelecer um juízo histórico de reprovação do comunismo como um sistema político. Outro caso notório de justiça política seria o julgamento de Eichmann em Jerusalém, comentado no famoso livro da filósofa alemã Hannah Arendt (1965), segundo a qual este julgamento visava, entre outras coisas, a qualquer custo reafirmar a condição de vítima dos judeus e a reprovar a visão de mundo engendrada pelo nazismo.

De modo parecido, quando a França levou o famoso Hauptsturmführer da SS Klaus Barbie a Lyon, em 1988, a expectativa era revisitar a representação de vítima da França ocupada. Vários grupos foram chamados ao processo para contarem sua versão da ocupação. O objetivo central era reunificar uma identidade política alquebrada na França da época. Neste ponto, o julgamento não foi tão bem sucedido. Na esteira de sua politização, a defesa de Barbie denunciou atrocidades francesas praticadas na guerra da Argélia. Ao fim e ao cabo, o processo virou uma espécie de comparação de práticas de genocídio (Cf. Finkelkraut, 1992).

\section{Jurisdição Universal e Cortes Internacionais}

O Tribunal Internacional para a Antiga Iugoslávia foi instalado ao cabo de um conflito que deixou cerca de 200 mil mortos. O objetivo era gerar reconciliação por meio da justiça, elaborar um relato histórico acerca das violações e remover de posições de poder alguns dos piores agressores. O Tribunal foi implementado por resolução do Conselho de Segurança da ONU. Um ano depois, em 1994, cerca de 750 mil pessoas foram brutalmente assassinadas em pouco mais de três meses durante uma guerra civil em Ruanda, o que levou à criação de um Tribunal similar para este país. 
$\mathrm{Na}$ época havia um sentimento de que uma Corte formada por membros de fora dos conflitos teria as vantagens da imparcialidade e da expertise que faltariam aos sistemas judiciais corrompidos pela corrupção e violência nestes países. Nestes casos, as sanções criminais foram vistas como imprescindíveis, em parte por conta da proporção das violações ao direito humanitário. Comissões da verdade para estes casos eram vistas como desnecessárias. Além disso, em ambos os casos, não se tratava exatamente de conflitos entre forças de segurança de um lado e oposição armada de outro. Em ambos haviam muitos grupos paramilitares envolvidos e realizando uma carnificina fortemente orientada por preconceitos étnicos e raciais (Cf. Roht-Arriaza, 2006).

Os estatutos, procedimentos e decisões destes tribunais se tornaram paradigmas para o desenvolvimento da legislação internacional do direito penal, e serviram como locus de treinamento para investigadores, advogados e juízes. Por meio dos julgamentos que levaram adiante, estas Cortes estabeleceram que chefes de Estado não são imunes a julgamentos diante de um tribunal internacional. Até 2006, o Tribunal para a Antiga Iugoslávia havia indiciado quase 100 pessoas, entre elas o ex-presidente Slobodan Milosevic. No mesmo período, o tribunal de Ruanda processou cerca de 52 líderes do genocídio (idem ibid.).

A partir do final dos anos 1990, outros dois fatores contribuíram para a conformação de um sistema judicial penal internacional e do conceito de jurisdição universal: a criação do Tribunal Penal Internacional (TPI) e a extradição de Augusto Pinochet.

O TPI, criado em 1998 pelo Estatuto de Roma, hoje assinado por mais de 100 países, tem jurisdição sobre genocídio, crimes contra a humanidade e crimes de guerra cometidos após $1^{\mathrm{o}}$ de julho de $2002 .{ }^{37}$ Diferentemente dos dois tribunais internacionais ad hoc, a competência do TPI é complementar à competência das Cortes nacionais. $\mathrm{O}$ processo só pode tomar lugar quando as Cortes nacionais estão impedidas de ou não querem fazê-lo. O argumento para a complementariedade da jurisdição do TPI se refere ao fato de que instituições nacionais têm mais acesso aos envolvidos e às provas, além de que, por uma questão de economia e coerência, os Estados são afinal os principais responsáveis pela implementação de suas obrigações internacionais. Ainda, com a preferência na condução dos julgamentos, as Cortes nacionais têm um estímulo para

\footnotetext{
${ }^{37}$ Os EUA se opuseram ferozmente ao TPI porque ele permitiria o julgamento de seus cidadãos, mesmo sem o país ter ratificado o Estatuto de Roma, em função de a competência do Tribunal ser determinada ou pela concessão da jurisdição ao Tribunal para o caso específico dada pelo país onde o agressor tem cidadania ou pela concessão de jurisdição ao Tribunal dada pelo país onde as violações foram cometidas.
} 
domesticar os princípios da legislação internacional dos direitos humanos e do direito humanitário (Cf. Schabas, 2001).

Segundo Freeman, (2009, p. 97), o trade off deste arranjo, no entanto, reside no fato de que, se o TPI vai agir apenas quando o Estado falhar, isto quer dizer que, no caso de condenação, será bem provável que o Tribunal enfrentará algum nível de resistência à compliance de sua decisão no nível doméstico. Por outro lado, a competência da Corte também deriva do princípio da jurisdição universal, segundo o qual qualquer Corte de qualquer país, inclusive o TPI, está obrigada a processar crimes considerados particularmente hediondos. São eles: crimes de guerra, genocídio e crimes contra a humanidade (Cf. Orentlicher, 2007, 2557). Quem os comete é considerado como hostis humani generis. Aqui é a natureza do crime que dá ensejo à jurisdição (universal, neste caso). Qualquer Corte de países signatários do Estatuto de Roma pode processar crimes desta natureza, mesmo que eles não tenham ocorrido no território sob sua jurisdição ou que qualquer dos envolvidos seja um cidadão do país.

Poucos meses depois da ratificação do Estatuto de Roma, o ex-presidente militar do Chile, Augusto Pinochet, foi preso em Londres por conta de um pedido de extradição formulado por uma Corte espanhola ao governo britânico em função do comando do expresidente na condução de casos de genocídio, terrorismo, tortura e outros crimes internacionais praticados dentro e fora do Chile. A Câmara dos Lordes britânica considerou que Pinochet não tinha imunidade sobre casos de tortura e que esta consistia numa das possibilidades de extradição para a Espanha (Cf. Orentlicher, 2004, 1070-89).

A Corte espanhola baseara seu pedido na jurisdição universal dos crimes contra os direitos humanos. No curso do processo, depois de ficar alguns meses em prisão domiciliar, Pinochet foi considerado inapto a encarar um julgamento por questões de saúde e foi mandado de volta para casa. Mesmo assim, caíram por terra os tabus que cercavam sua personalidade antes tida como intocável. Pinochet passou a ser indiciado em uma série de processos desde então e perdeu sua imunidade parlamentar. Muitos de seus assessores e colaboradores foram presos.

\section{Crimes contra a humanidade}

A restrição usualmente mais aceita por Tribunais nacionais e internacionais à aplicação de excludentes de punibilidade são os chamados "crimes contra a humanidade". Seu conceito passou a constar como um símbolo reinante de uma concepção substantiva 
da rule of law no Estado liberal. O crime contra a humanidade é a forma extrema da perseguição política, pois transcende as fronteiras nacionais e ofende a comunidade internacional. Tipificado pela primeira vez na Carta de Nuremberg, o crime contra a humanidade compreende ofensas graves como homicídio, deportação e tortura, realizadas de forma sistemática (Cf. Teitel, 2000, p. 59 e seguintes).

Indo além de tribunais de guerra anteriores, Nuremberg tomou para si a jurisdição sobre perseguições cometidas pelo Estado contra seus próprios cidadãos. Considerou-se que as violações em questão transcenderam a lei nacional e violaram a lei de todas as nações, e, nesta medida, eram passíveis de processo e julgamento por um tribunal internacional. ${ }^{38} \mathrm{Na}$ medida em que é concebido como uma ofensa a toda a humanidade, este crime dá ensejo ao princípio jurisdicional correlato da "universalidade".

A European Convention for the Protection of Human Rights and Fundamental Freedoms $^{39}$, de 1950 , em seu artigo 7(2), já eximia os crimes contra a humanidade de restrições à retroatividade de sua aplicação: "este artigo não deverá prejudicar o julgamento e punição de qualquer pessoa por qualquer prática ou confissão que, ao tempo em que foi cometida, era criminosa de acordo com os princípios gerais do direito reconhecidos pelas nações civilizadas". ${ }^{40} \mathrm{O}$ conceito foi bastante utilizado e aceito em processos como o de Eichmann em Jerusalém, e em processos de justiça retrospectiva na Argentina, Chile e Iugoslávia.

Nestes casos, o processo tem a vantagem de, apesar de afetado pelas circunstâncias políticas em que ocorreram os crimes, não ser conduzido por elas, fazendo prevalecer a força normativa da lei. $\mathrm{O}$ conceito de crimes contra a humanidade conecta regimes no espaço e no tempo, perpetuando um sentido de responsabilidade contínua por violações passadas que é construtivo de uma identidade do Estado através dos regimes.

Em julgamentos que ocorreram na Alemanha em meados da década de 1960, apesar dos esforços do Parlamento alemão da época de pôr um fim aos julgamentos sobre a Segunda Guerra e apesar de os prazos de prescrição sobre os crimes em questão já terem estourado na época, venceu o argumento segundo o qual o Judiciário alemão não era

\footnotetext{
${ }^{38}$ Mesmo assim, e apesar da outra novidade trazida pelo Tribunal de Nuremberg a respeito da retroatividade da lei nestes casos, os processos ficaram limitados à guerra propriamente dita. Com isso, os crimes contra a humanidade foram absorvidos, na prática, por outros crimes de guerra. A respeito do Tribunal de Nuremberg e do conceito de crimes contra a humanidade, ver também Schelb (1946) e Clark (1990).

${ }^{39}$ Disponível em: http://www.echr.coe.int/Documents/Convention_ENG.pdf. Último acesso em 24 de maio de 2015.

${ }^{40}$ No original: "This Article shall not prejudice the trial and punishment of any person for any act or admission which, at the time it was committed, was criminal according to the general principles of law recognized by civilized nations".
} 
independente durante o domínio nazista. Já em 1979, a questão voltou à tona e então se estabeleceram limites: apenas homicídios cometidos por motivação racial ou étnica não seriam suscetíveis à prescrição (Cf. Monson, 1992, p. 605).

Do ponto de vista do Direito Internacional, o dilema foi resolvido pela Convenção das Nações Unidas pela Não-Aplicabilidade de Prescrições a Crimes de Guerra e Crimes Contra a Humanidade (Resolução 2391 da Assembleia Geral das Nações Unidas, de 11 de Novembro de 1970).

No caso deste tipo de crime, ao invés de diminuir, a busca por persecução criminal aumenta conforme o período do autoritarismo se afasta e a democracia se consolida (Cf. Teitel, 2000, p. 63). Isto por conta da natureza destes delitos, particularmente a cumplicidade do Estado com seu cometimento. Quando isso acontece, aspectos importantes das violações são acobertados por mais tempo e só emergem com a passagem do tempo e com o engajamento de ativistas. As condições de possibilidade dos julgamentos exigem a mudança de regime.

Klaus Barbie, por exemplo, só foi extraditado da Bolívia para a Europa depois de uma mudança de regime na Bolívia, cerca de 40 anos depois das atrocidades que ele cometera na Europa. No leste europeu, apenas com a queda da cortina de ferro foi possível ampliar o acesso à documentação das polícias políticas e dos Partidos Comunistas, dando ensejo a várias informações que sustentariam alguns julgamentos.

Desenvolvimentos recentes no direito internacional expandiram a definição de crimes contra a humanidade, impondo mais restrições à soberania dos Estados. A princípio, o conceito abrangia um tipo específico de vítimas, em geral ligadas a guerras com perseguições étnicas, raciais ou religiosas. A conceitualização contemporânea é mais abrangente e se estende a violações praticadas contra cidadãos em tempos de paz, de modo a criar um sistema de proteção internacional contra perseguições étnicas, raciais, religiosas e também políticas.

A partir do caso Barbie julgado pela Corte francesa, o que distingue o crime contra a humanidade é a intenção de perseguir. A mesma coisa pode ser dita a respeito do Tribunal Internacional para a Antiga Iugoslávia (idem ibid.). Quando o Estado é cúmplice da perseguição, alguns dos princípios mais caros e em geral tidos como intangíveis do direito penal como a equidade e a segurança jurídica são colocados em xeque. A luta por justiça em contextos transicionais e pós-transicionais dá a dimensão da mensagem normativa de "proteção igual" e equidade, que são base da rule of law. Julgar crimes 
contra a humanidade ajuda a construir a mudança normativa ao condenar a repressão do passado e restaurar a segurança e a proteção equitativa.

\subsection{2) Direito à verdade}

Elucidar os fatos e razões relacionados a graves e sistemáticas violações aos direitos humanos no passado pode ser fundamental para o estabelecimento da nova ordem política. Cada vez mais, a literatura tem considerado que a revelação da verdade responde a uma demanda das vítimas por justiça. ${ }^{41}$ Como bem destaca Teitel (2000, p. 69), a literatura sobre a temática tem entendido que o processo de elucidação da verdade deita a base necessária para a nova ordem democrática. Tal concepção remonta a uma visão iluminista da História tal como expressa em Kant ou Hegel, em que a própria história desempenha um papel universalizante e redentor. A quase equiparação entre "verdade" e "história" a propósito da implementação do direito à verdade em processos justransicionais é sinal desta visão iluminista altamente normativa e redentora da história. $^{42}$

As narrativas elaboradas a propósito das políticas de verdade geralmente se engajam em mostrar a descontinuidade ou ruptura entre regimes. Impedir que violações futuras aconteçam é geralmente um dos argumentos centrais em favor da punição de antigos perpetradores. Mas essa função prospectiva da rule of law nas transições também pode ser alcançada por meios administrativos. As comissões da verdade modernas desafiam nossas intuições sobre a natureza e a forma como procede a justiça tradicional.

O reconhecimento público sobre o passado é produzido por um processo elaborado em que violadores, vítimas, funcionários públicos e personalidades políticas têm a chance de falar, envolvendo a sociedade em um debate ampliado e em vista de um consenso social. Trata-se de um processo não-adversarial (não litigioso) que liga julgamento histórico a consenso social potencial.

Ao contrário do poder judicial, as comissões da verdade não têm a prerrogativa de determinar o cumprimento de suas recomendações. Embora muitas tenham poderes investigativos amplos, como intimação (como na África do Sul e no Brasil), nenhuma delas exerce poderes judiciais completos. Por outro lado, os procedimentos das comissões

\footnotetext{
${ }^{41}$ Sobre a relação entre verdade e justiça, ver particularmente Roht-Arriaza e Margaret Popkin (1995).

${ }^{42}$ Por outro lado, esta tarefa se ergue numa época permeada pela pós-modernidade, em que as viradas linguística e interpretativa relativizam a objetividade das investigações históricas (Cf. Gadamer, 1989).
} 
da verdade também têm a vantagem de serem mais democráticos do que os processos criminais, na medida em que estão mais abertos ao debate público e possuem uma carga menos inquisitiva.

De acordo com Teitel (2000), na medida em que os regimes do passado passam a ser conhecidos por seus simulacros e tentativas de esconder violações, o ritual das comissões da verdade tem a função de colocar tudo a nu e dar voz a todos, especialmente às vítimas. $\mathrm{O}$ direito a audiências reafirma publicamente o direito de participação e dignidade individual. A mensagem que se transmite por meio destes procedimentos é a de que o indivíduo social importa para a construção de sentido e para a definição de políticas a partir do Estado.

Questões sobre como elas se organizam, estruturam sua metodologia de trabalho, realizam audiências públicas ou sob segredo ou se identificam ou não o nome dos perpetradores são questões resolvidas de modo distinto em diferentes contextos. Segundo Hayner (2011), 40 comissões da verdade foram criadas até 2010, e muitas outras estariam em curso na época, inclusive a brasileira. As distintas experiências variaram muito no grau de sucesso, alerta a pesquisadora, mas sempre há algum grau de frustração a seu respeito.

\section{Primeiras comissões da verdade e experiências análogas}

Em países como Argentina e Chile, a figura do desaparecido facultou uma brecha legal por onde operadores do direito puderam começar a argumentar em favor da responsabilidade contínua dos agressores mesmo após a transição. Segundo o argumento desenvolvido por alguns promotores de justiça e advogados de familiares de desaparecidos, se o corpo continua desaparecido, o crime pode ser considerado como ainda em curso, isto é, como um crime permanente, e nesta medida não seria possível falar em prescrição porque a contagem de seu prazo sequer teria começado (Cf. Teitel, 2000, p. 77). Entretanto, com a definição de uma estratégia jurídica para a luta pela justiça, os operadores do direito começaram a se defrontar com a difícil tarefa de comprovar os desaparecimentos. ${ }^{43}$ Mesmo porque, se a ideia da repressão era justamente sumir com qualquer tipo de prova, isto dificultava a atuação dos promotores e advogados.

A partir de países como Argentina e Chile, as comissões da verdade (e instituições análogas) foram criadas em boa parte para responder a este problema e também para dar

\footnotetext{
${ }^{43} \mathrm{O}$ mandato da Comissão da Verdade e Reconciliação no Chile também abrangeria execuções sumárias e extrajudiciais.
} 
alguma dimensão de uma justiça corretiva aos familiares. O escopo principal destas comissões é justamente estabelecer os fatos que envolveram desaparecimentos, homicídios, torturas e outras violações em massa praticadas em um passado recente (idem ibid.). As violações institucionais parecem exigir sua contrapartida institucional, numa dimensão que pode dar conta de investigações sobre uma política sistêmica e massiva de perseguição a opositores.

A primeira comissão da verdade mundialmente conhecida foi a argentina CONADEP (Comisión Nacional sobre la Desaparición de Personas), estabelecida em 1983 e formada por dez indivíduos independentes e respeitados, entre bispos, advogados, um jornalista, um matemático e outros. ${ }^{44}$ Seu chefe era o escritor Ernesto Sábato. O objetivo da CONADEP era esclarecer apenas desaparecimentos, e em vista deste propósito, seus membros e seu staff inspecionaram prisões, cemitérios clandestinos, delegacias de polícia, entre outros estabelecimentos. Muitos testemunhos foram transmitidos nacionalmente e contaram com ampla cobertura pelos jornais. Depois de 9 meses, um relatório bastante extenso, intitulado Nunca Más, identificou cerca de 9 mil casos de desaparecimento, reputando as vítimas como presumivelmente mortas para fins de desobstrução de heranças e outras questões burocráticas. Nunca Más, que se tornou um best-seller, também documentou a natureza sistemática da repressão da Junta Militar (Cf. Neves, 2014, p. 22). ${ }^{45}$

Por outro lado, embora tenha identificado muitos desaparecidos, o relatório não individualizou os agressores. Este foi um ponto bastante controverso. O relatório atribuiu responsabilidade pelas violações genericamente a segmentos da Junta Militar, e esta atribuição de responsabilidade foi a base alguns anos depois para os processos criminais contra os comandantes militares.

Depois desta experiência, outras comissões da verdade se espalharam rapidamente pela América Latina. Onde quer que houvesse impedimentos legais a processos contra agressores ligados ao Estado durante o período militar, as comissões da verdade começaram a aparecer como uma alternativa viável para algum tipo de resposta àquelas violações. Onde quer que a violência tivesse sido massiva em relação ao total da população (como na Argentina, Chile, El Salvador, Honduras, Haiti e Guatemala), as

\footnotetext{
${ }^{44}$ Ver Nunca Más: Report of the Argentine National Commission on the Disappeared (1986). A utilização do termo "comissão da verdade" começou a se consolidar apenas na década seguinte.

${ }^{45}$ Segundo estimativas acerca do total de desaparecimentos forçados praticados por agentes de Estado durante a repressão militar na Argentina, o número total de casos deve ter sido de 25 a 30 mil desaparecimentos, embora cerca de 9 mil casos (um número bastante expressivo) tenham sido esclarecidos pela CONADEP.
} 
comissões da verdade se transformaram, pelo menos a princípio, no mecanismo central da justiça de transição.

Ao cabo da guerra civil em El Salvador, depois de quase uma década, com cerca de 75 mil mortos e milhares de sem teto, os acordos de paz estipularam a criação de uma comissão da verdade internacional. Tendo funcionado entre 1992 e 1993, seu escopo era documentar "sérios abusos" cometidos tanto pelas forças do governo quanto pela oposição. Pela primeira vez desde a Segunda Guerra, uma investigação "imparcial” sobre as violências do passado seria conduzida por uma instituição internacional.

$\mathrm{Na}$ África, depois de regimes autoritários, comissões parecidas foram criadas em Uganda, Chade e na África do Sul. Nesta última, o "Promotion of National Unity and Reconciliation Act", de 1995, dava os contornos da Comissão da Verdade e Reconciliação. Sua função era tratar do legado do passado e prover uma imagem da "natureza, causas e extensão de graves violações aos direitos humanos" de 1960 a 1994, de acordo com o preâmbulo do documento. ${ }^{46}$

O governo Mandela fez várias audiências públicas e permitiu que a sociedade civil indicasse candidatos para compor o conjunto de membros da Comissão. Nenhum dos 17 escolhidos era político. Além disso, havia representantes de todos os grupos étnicos e, apesar de haver alguns advogados, a maioria era composta por membros de Igrejas ou organizações da sociedade civil (Cf. Neves, 2014, p. 38-39). Presidida pelo antigo arcebispo de Cape Town, Desmond Tutu, comparada a outras comissões congêneres, a sul-africana tinha o poder especial de conferir anistias individuais.

Priscilla Hayner (2011, p. 27 e seguintes) sustenta que os poderes investigativos da Comissão foram potencializados por um sofisticado programa de proteção às vítimas. $\mathrm{E} o$ orçamento era muitas vezes maior do que o de qualquer outra comissão similar no passado. Também foram publicados os nomes dos perpetradores em seu relatório final, que em seus vários volumes reconheceu o cometimento de "graves violações aos direitos humanos" por todas as partes do conflito, assim como a longa história social e institucional do apartheid. Em uma sociedade altamente dividida, a verdade teria o condão de promover reconciliação.

Na medida em que os testemunhos eram absolutamente centrais para a Comissão não apenas no que poderiam fornecer de informações para a produção do relatório final,

\footnotetext{
${ }^{46}$ Disponível em: http://www.justice.gov.za/legislation/acts/1995-034.pdf. Último acesso em 24 de maio de 2015. Sobre os trabalhos da Comissão da Verdade e Reconciliação na África do Sul, ver também Asmal, Asmal e Roberts (1997).
} 
mas também em vista do objetivo de promover um palco público para a veiculação da voz das vítimas e para a justificação e confissão dos atos praticados pelos perpetradores, a Comissão contava com uma estrutura de estímulos à participação e colaboração de testemunhas. A "cenoura" desta estrutura era a possibilidade de concessão de anistia para quem os membros julgassem que havia colaborado de modo satisfatório. O "porrete” era a possibilidade de investigação criminal, processo e condenação, na via judicial, de quem não colaborasse com a Comissão. Aqueles que cometeram graves violações só poderiam ser anistiados depois de audiências públicas das quais suas vítimas seriam notificadas. Além disso, o agressor deveria fazer um relato completo de seus atos e estes deveriam estar associados a motivos políticos para que a anistia pudesse ser concedida.

$\mathrm{Na}$ medida em que a anistia poderia ser concedida somente para aqueles que foram tidos como responsáveis pelas atrocidades, responsabilização individual e anistia caminhavam juntas, sem promover esquecimento (resultado muitas vezes ligado às anistias promovidas na América Latina). Para Neves (2014, p. 28), a África do Sul provou que os julgamentos não são o único lócus para a atribuição de responsabilidades. Além disso, se em processos judiciais os agressores se colocam numa posição defensiva, na Comissão da Verdade e Reconciliação eles tinham o estímulo para fazer um relato completo de seus atos. Neste sentido, a maior parte das informações coletadas pela Comissão tinha sua origem em depoimentos dos próprios perpetradores.

O modelo de concessão de anistias desenvolvido pela Comissão sul-africana se aproxima da relação entre perdão e justiça comentada por Hannah Arendt em $A$ condição humana. Para a filósofa alemã (Arendt, 2008), em seu sentido político, o perdão não implica esquecimento. Somente pode perdoar em sentido próprio quem, apesar de ter o poder de punir, decide abrir mão da punição. Somente nestes termos, o perdão pode mostrar que, apesar de não punidos em sentido penal, os crimes realizados são considerados como condenáveis. ${ }^{47}$

Sem terem produzido a mesma dimensão de justiça corretiva da Comissão sulafricana, a CONADEP na Argentina e a Comissão da Verdade e Reconciliação no Chile encaminharam suas investigações para o Judiciário de seus países. Até meados da década de 2000, afora a condenação de alguns comandantes da Junta Militar na Argentina, as anistias prevaleceram em boa parte dos países latino-americanos, onde a revelação da

\footnotetext{
${ }^{47} \mathrm{O}$ perdão, para Arendt, é o oposto da vingança porque não é propriamente uma reação, mas uma ação nova com vistas a cessar as consequências de uma violação passada. Ele também depende da pluralidade, isto é, ninguém pode perdoar a si mesmo. Sobre o conceito de perdão aplicado à justiça de transição na África do Sul, cf. Teles (2007).
} 
verdade aparecia como uma segunda melhor opção em alternativa às condenações. ${ }^{48}$ As comissões da verdade eram tidas como menos perigosas para a estabilidade ao mesmo tempo em que não ignoravam as violações do passado. Esta ênfase nas políticas pela verdade na América Latina teria levado, segundo Roht-Arriaza (2006), a muitas elaborações no continente sobre por que o direito à verdade deve ser valorizado.

$\mathrm{Na}$ América Latina, as razões para a instalação de comissões da verdade são geralmente elaboradas em oposição às ditaduras militares, em que muitas vezes as violações (sobretudo a figura marcante do desaparecimento forçado no Cone Sul, especialmente na Argentina) eram acobertadas e as forças de segurança se recusavam a reconhecer o sequestro, tortura, encarceramento e homicídio de pessoas.

Onde a instalação das comissões da verdade não é realizada ou foi bastante tardia, muitas vezes são desenvolvidos projetos não governamentais que documentam padrões de abusos em regimes anteriores. Os exemplos mais proeminentes vêm do Brasil e do Uruguai. No Brasil, terminado o período ditatorial em 1985, apenas em 2012 foi instalada uma comissão da verdade pelo Estado. No Uruguai, com o fim da ditadura no mesmo ano de 1985, a Comisión para La Paz foi criada apenas em 2000.

No caso brasileiro, um time de pesquisadores conseguiu, ainda durante o período militar, fotocopiar secretamente documentos de Cortes judiciais sobre reclamações de tortura por presos políticos. Cerca de um milhão de páginas foram contrabandeadas. Com apoio do arcebispado de São Paulo e do Conselho Mundial de Igrejas, o grupo produziu o livro Brasil: nunca mais (1985), relatando práticas de tortura do regime militar brasileiro realizadas em um período de 15 anos. ${ }^{49}$

No caso uruguaio, o Sevicio Paz y Justicia (SERPAJ) publicou um livro com título homônimo em espanhol, Uruguay: nunca más (1989), um relato muito mais contundente do que o que resultaria da Comisión para La Paz sobre o paradeiro dos desaparecidos, pois esta funcionaria com mandato bastante curto e com restrito apoio político. A comissão oficial que seria gerida pelo Parlamento uruguaio omitir-se-ia a respeito dos abusos que na verdade ganharam maior proporção no país: o encarceramento ilegal e a tortura (Cf. Hayner, 2011, p. 14 e seguintes).

\footnotetext{
${ }^{48} \mathrm{Na}$ Argentina, a Lei da Obediência Devida e a Lei do Ponto Final seriam consideradas como inconstitucionais pela Suprema Corte do país a partir de meados dos anos 2000. Antes disso, nos primeiros anos pós-transição, alguns militares da cúpula da repressão política reunidos na Junta Militar haviam sido julgados e condenados, inclusive o ex-ditador Jorge Rafael Videla.

49 Sobre a realização deste projeto, ver Lawrence Weschler (1990).
} 
Tanto o projeto brasileiro quanto o uruguaio emularam, até no título, o relatório da comissão argentina. Pelo próprio nome dos relatórios, vê-se que um dos seus objetivos centrais era impedir futuras violações por parte do Estado, objetivo este que também é geralmente atribuído à função da justiça.

\section{O direito à verdade, definição e objetivos das Comissões da Verdade}

Em sua a definição revisada para a segunda edição de seu livro, Priscilla Hayner (2011, p. 10 e seguintes) assevera que as comissões da verdade possuem as seguintes características: 1) são focadas no passado, 2) investigam um padrão de violações que ocorreram em tempo específico, 3) se engajam direta e amplamente com a população afetada, reunindo informações sobre suas experiências, 4) têm prazo para realizar seus trabalhos, concluindo com um relatório final, 5) são oficialmente autorizadas ou sustentadas pelo Estado. Em contraste com as Cortes criminais, as Comissões da Verdade têm algumas prerrogativas a menos, pois não podem determinar a prisão de perpetradores ou a observância de suas recomendações, e muitas não têm sequer o poder de intimação para a prestação de depoimentos. Apenas a Comissão da Verdade e Reconciliação da África do Sul tinha o poder de conceder anistias.

Por outro lado, este tipo de comissão tem a vantagem de aprofundar mais as investigações e relacionar responsabilidade individual com responsabilidades institucionais e coletivas, bem como desvendar os significados da repressão e padrões de violência, o que muitas vezes não é possível fazer ou nem mesmo é apropriado em Cortes de Justiça. Em seu trabalho, elas podem avaliar inclusive a própria responsabilidade do Judiciário durante a repressão.

Embora a maioria das comissões tenha colaborado com a persecução criminal, elas são principalmente focadas nas vítimas, geralmente redimindo em alguma medida sua atuação no passado e condenando as atrocidades cometidas ao reunir centenas ou milhares de seus testemunhos.

Entre os fatores que podem influenciar os contornos das políticas de justiça transicional, Hayner destaca a autonomia e força política de grupos e indivíduos envolvidos com a causa, bem como a relevância e influência dos responsáveis pelos abusos e sua capacidade de controlar ou ao menos constranger o rumo destas políticas. Também o interesse, a penetração e o papel de organizações internacionais são importantes no processo. 
As escolhas no desenho das políticas públicas voltadas para a implementação do direito à verdade também são afetadas pelo tipo e magnitude das violências do passado e pela natureza e forma da transição política. A cultura política nacional é outro fator comentado por Hayner (2011, p. 17 e seguintes) que ajuda a configurar os parâmetros destas políticas, se e de que forma o passado é confrontado. Mas, contrariando outro senso comum a respeito do tema, o número relativo de vítimas parece não ser uma variável independente neste quesito, se se leva em conta as múltiplas experiências mundo afora nos últimos anos.

O principal objetivo das comissões da verdade é revelar a "verdade factual" ao traçar uma narrativa acurada do passado de repressão de um país. Hayner (2011, p. 20 e seguintes) sustenta que a qualidade dos testemunhos colhidos em audiências nestas instituições costuma ser superior àqueles colhidos em instâncias judiciais, pois nestes casos os depoimentos das testemunhas são constrangidos pelos procedimentos legais.

Ativistas de direitos humanos geralmente dizem que as comissões revelam poucas verdades desconhecidas, mas têm a função precípua de torná-las públicas com o reconhecimento do Estado e com a emissão de um juízo de valor a seu respeito, geralmente veiculado a propósito dos relatórios das comissões. De acordo com RohtArriaza (2006), a abertura de arquivos históricos e a instalação de comissões da verdade ao lado de demissões de antigos oficiais envolvidos em violações dão o tom das políticas justransicionais. As funções centrais associadas à elucidação da verdade são contrariar a negação histórica do Estado e determinar a extensão, natureza e origem dos crimes, além de identificar os violadores e colaboradores.

Outro dos objetivos essenciais relacionado a seus trabalhos é ouvir, respeitar e responder às necessidades das vítimas e sobreviventes. Em seus procedimentos não há o constrangimento das respostas estritamente objetivas às perguntas dos operadores do direito em processos judiciais nem as acareações que constrangem os depoentes. $\mathrm{Na}$ África do Sul, o processo dos testemunhos também foi planejado para ser uma ocasião de catarse. Se o regime anterior não foi capaz de proteger a integridade das pessoas, mais do que isso, se ele foi responsável por violá-la da forma mais profunda, a audiência pública da vítima precisa ter uma dimensão de justiça corretiva, para reabilitar algo da dignidade ferida no passado.

Embora, segundo a literatura (Cf. Hayner, 2011, p. 27 e seguintes), as audiências nem sempre tenham produzido o efeito de catarse esperado na África do Sul, o fato é que, hoje, pouquíssimas pessoas defenderiam publicamente no país o regime do apartheid ou 
negariam a prática sistemática de tortura pelas forças de segurança, algo que era bastante comum antes, mesmo nos primeiros anos da transição. Neste sentido, em suas versões mais bem sucedidas, os processos associados às comissões da verdade também têm o papel de legitimar o regime atual. Aqueles a quem foram negadas a integridade física e psíquica e a voz podem agora falar abertamente sobre suas experiências sob a repressão (Cf., a este respeito também, CONADEP Report, 1986, p. 5).

Os relatórios das comissões geralmente são bastante minuciosos quanto à documentação dos fatos, indicando o local onde o crime ocorreu, as instituições e pessoas envolvidas, datas e horários com a maior precisão possível. Quanto mais detalhado, maior a força indutiva do relatório em oposição ao negacionismo oficial anterior (ou mesmo atual em relação às forças de segurança, em muitos casos). No Chile, o presidente Patricio Aylwin apresentou o relatório da Comissão da Verdade e Reconciliação em um estádio, acrescentando à apresentação um pedido de desculpas formal (Cf. Teitel, 2000, p. 82-83). O mesmo estádio tinha sido palco de prisões ilegais e tortura no passado autoritário.

Essa dimensão simbólica do pedido oficial de perdão pelo chefe de Estado tem pelo menos dois significados: a reabilitação das vítimas e o reconhecimento da continuidade do Estado, e portanto de sua responsabilidade. Ao mesmo tempo, aponta para a superação do passado de violações. $O$ pedido de perdão indica, em suma, que o Estado é o mesmo e que continua a ser responsável pelas práticas do passado, mas que o regime efetivamente mudou - não apenas na questão dos direitos e liberdades políticas (o que é geralmente representado pelo retorno das eleições livres) -, mas também em relação aos direitos e liberdades civis e ao respeito à rule of law, sobretudo no que se refere à exigência de que ninguém, nem mesmo políticos, militares e outros agentes estatais, está acima da lei.

A mudança nas categorizações também é importante. De termos como "guerrilhas", "guerra contra a subversão" e "imposição da ordem", passa-se a "vítimas", “terrorismo de Estado", "violações aos direitos humanos", "perpetradores" etc. ${ }^{50}$ É neste sentido que se pode dizer que os relatórios das comissões da verdade têm a função de dar respostas críticas às justificativas do regime anterior para operar a violência institucionalizada. Desaparecimentos, torturas, prisões ilegais, homicídios, cassações de

\footnotetext{
50 Cf. Chilean National Commission on Truth and Reconciliation (1993), disponível em: http://www.usip.org/sites/default/files/resources/collections/truth_commissions/Chile90-Report/Chile90Report.pdf. Último acesso em 24 de maio de 2015.
} 
mandatos políticos e exonerações de cargos públicos não poderiam ser justificados por razões de "segurança nacional" ou similares.

A primeira decisão clara no sentido da obrigação de um Estado implementar o direito à verdade foi veiculada pela Corte Interamericana de Direitos Humanos (CrIDH) no caso Velásquez-Rodríguez versus Honduras, de 1988. De acordo com esta decisão, o Estado tem um dever de investigar o destino dos desaparecidos e franquear as informações aos parentes. Este entendimento foi reafirmado pelo "Report of the Independent Expert to update the set of principles to combat impunity", feito por Diane Orentlicher (2005), e pelo "Resolution Adopted by the Human Rights Council: Right to the Truth" (UN Human Rights Council, 2009). Estes documentos, além de consolidarem a obrigação dos Estados de promover o direito à verdade, exigem que os Estados preservem e deem acesso a arquivos sobre violações do passado.

\section{$A$ verdade é multifacetada}

Elster (2004, p. 121) considera que outra questão delicada é se a elucidação da verdade incluirá apenas práticas de violações cometidas por agentes e colaboradores do regime repressivo anterior ou se também cobrirá a atuação de membros da oposição armada. Na "Promotion of National Unity and Reconciliation Bill", de 1995, que regulava os trabalhos da Comissão da Verdade e Reconciliação da África do Sul, membros do movimento de libertação e membros das forças de segurança são tratados de forma inteiramente simétrica. O próprio Desmond Tutu, o bispo da Igreja anglicana que presidiu a Comissão, ameaçou desligar-se dela se o Congresso Nacional Africano (CNA) não admitisse também ter sido responsável por violações aos direitos humanos. As duras audiências sobre a atuação de Winnie Mandela, por exemplo, mostram que, de fato, a Comissão se ateve a este princípio. No volume 2 do relatório, junto com a avaliação do terrorismo de Estado são relatados os atos de violência dos movimentos de libertação.

$\mathrm{Na}$ Argentina, o presidente Raúl Alfonsín incluiu entre os princípios dos julgamentos que afetariam os comandantes da Junta Militar mais tarde que tanto agentes do Estado quanto "terroristas subversivos" deveriam ser punidos. Da mesma forma, a Comissão da Verdade e Reconciliação no Chile estava encarregada de investigar não apenas o terrorismo de Estado, mas também o praticado por membros da oposição armada. Cerca de 4\% das violações documentadas por esta Comissão entram nesta categoria (cf. Elster, 2004). 
Algo parecido se deu em comissões da verdade decorrentes de acordos bilaterais entre dois lados de conflitos em países da América Central (como El Salvador e Guatemala) e da África. Este é um modelo positivo, considera Teitel (2000), para transições pós-guerras civis. O relatório da Comissão de El Salvador tinha uma seção intitulada "Violência contra opositores por agentes do Estado" e outra intitulada "Violência contra opositores pela Frente Farabundo Marti para La Libertación Nacional". A Comissão procedeu à investigação de casos paradigmáticos de violência de parte a parte.

Ainda que a maioria destes exemplos se refira a casos de guerra civil, guerra mundial ou totalitarismo, não é a abrangência da violência que está em questão, mas sua natureza. Constituindo violações sérias aos direitos humanos, estas práticas deveriam ser objeto dos relatos das comissões da verdade, pois este é justamente seu escopo central: relatar e avaliar sérias violações de direitos humanos cometidas no passado em período de autoritarismo ou guerra. A delimitação do período também é importante porque não se pode supor que em democracias não existam graves violações aos direitos humanos (pelo contrário, como inúmeros estudos indicam, elas são bastante frequentes em democracias também). Por isso, não é possível supor que, natural e automaticamente, avaliações sobre violações aos direitos humanos se refiram a períodos de autoritarismo ou guerra, sendo importante, portanto, delimitar este período, elemento que integra a própria definição das comissões da verdade.

Na medida em que estas comissões constroem uma nova narrativa sobre o passado, elas ajudam a mudar a configuração do cenário político e jurídico sobre o tema. E isso muitas vezes leva a facilitar o desenho e implementação de outras políticas de justiça transicional, como reparações às vítimas e familiares, reformas institucionais e mesmo o julgamento e condenação de violadores dos direitos humanos. Nos termos de Thomas Kuhn (2011) em Estrutura das revoluções científicas, se o mundo é tal como o enxergamos, não é exagero dizer que uma das tarefas das comissões da verdade é promover uma mudança de paradigma na visão da história recente do país, com particular atenção à avaliação crítica das justificativas dadas de parte à parte, sobretudo pelo Estado e pelas forças de segurança, a respeito da violência sistemática que tenham eventualmente empregado.

Se algumas justificativas até então usualmente veiculadas caem por terra, como o "combate ao terrorismo subversivo" e a "segurança nacional", e se outras justificativas como "resistência" e "combate ao terrorismo de Estado" passam a ser reconhecidas não há 
mais motivo para se manter o status quo de uma série de garantias (de um lado) ou de negações de demandas (de outro). Mas um tal desígnio só pode ser alcançado de forma mais convincente na medida em que as práticas de todos os lados de um conflito são objeto de avaliação pelas comissões. Não realizar uma avaliação sobre a atuação de grupos envolvidos com a luta contra a repressão, por exemplo, pode até mesmo prejudicar a credibilidade do trabalho das comissões da verdade e obscurecer o entendimento sobre pelo que aqueles grupos lutavam e no que acreditavam. Nestes casos, além de eventualmente complicar o objetivo de redimir a atuação destes grupos, uma tal omissão pode distorcer a visada sobre suas práticas, reduzindo-as aos sofrimentos que lhes foram infligidos. Inversamente, porém, a atuação destes grupos invariavelmente tinha uma dimensão e importância política tamanha que não poderia ser reduzida à sua condição de vítima.

\section{Verdade versus Justiça ou Verdade e Justiça}

A experiência da África do Sul passou a ser a mais conhecida de todas. Sua Lei de Anistia era prevista pela Constituição interina, mas, como vimos acima, o Parlamento decidiu condicioná-la à revelação completa dos crimes cometidos pelos indivíduos que buscassem anistia.

Não se tratava de uma segunda melhor opção onde os julgamentos não seriam possíveis. Como destaca Roht-Arriaza (2006), acreditava-se que uma comissão da verdade poderia realizar coisas que nenhum julgamento poderia. Ela poderia focar no padrão comum às violações, mais do que nos violadores, permitir que vítimas testemunhassem em um ambiente mais propício à cura do que nas inquisições associadas aos depoimentos na justiça. Ela também permitiria que se emitisse um juízo sobre a política do passado, não apenas sobre os atos e omissões individuais.

Trocando anistia por confissões, a Comissão da Verdade e Reconciliação da África do Sul também pôde extrair informações dos agressores que de outra forma dificilmente teriam sido elucidadas. O procedimento não judicial, afirma Roht-Arriaza (2006, p. 4), também se mostrou melhor para lidar com a característica complexa (e não necessariamente maniqueísta) que caracteriza muitos conflitos.

A maioria das comissões da verdade não nomeia os perpetradores. Onde isso acontece, pode ser um claro sinal de que a comissão, além de levar a efeito uma finalidade endógena de accountability pela atribuição de responsabilidades e pela construção de uma 
narrativa sobre o passado, configura-se também como um passo para a busca da justiça criminal.

Teitel (2000, p. 89) sustenta que, embora as comissões da verdade não sejam, do ponto de vista normativo, necessariamente uma alternativa excludente à busca por justiça criminal (como muitas das experiências já comentadas aqui demonstram empiricamente), ela pode se apresentar como uma alternativa em contextos em que a justiça criminal não passa de uma possibilidade remota. Nestes contextos, a identificação de perpetradores com a publicidade de seus atos tem sido considerada uma forma de justiça retributiva "nãopunitiva" (pelo menos não no sentido do direito penal tradicional). Isso aconteceu, por exemplo, na Comissão da Verdade e Reconciliação do Chile (cuja atividade se desenrolou em uma época em que os processos criminais ainda eram uma realidade distante neste país), e nas comissões da Guatemala, El Salvador e mesmo África do Sul. Estas comissões veicularam condenações morais aos perpetradores.

Esta relação de proximidade entre verdade e justiça ganhou sua máxima expressão na Comissão da Verdade e Reconciliação da África do Sul, onde os relatos, narrativas e anistias eram realizados caso por caso. Onde a verdade era condição para a anistia, não houve um trade off entre justiça e verdade, mas, ao contrário, uma dimensão também retributiva na exigência de esclarecimento dos fatos (uma confissão) como condição para a anistia, ao mesmo tempo em que não se realizava nova fratura na sociedade por meio daquilo que poderia ter sido o encarceramento de muitas centenas, talvez milhares de pessoas.

A dimensão retributiva, neste caso, estava tanto na exigência da confissão (caso contrário, o agressor poderia ser processado pela justiça criminal) quanto no conhecimento pela sociedade de seus atos, algo que, dependendo do caso, poderia gerar constrangimentos ou até certo ostracismo social.

Se de um lado foi um bom grau de aceitação social que possibilitou as violências do passado, as comissões da verdade têm a função de chamar a atenção para isso e destacar a importância da democracia e da rule of law em contraposição ao autoritarismo. Embora as comissões geralmente se isentem de uma função jurisdicional (isto é, de dizer o direito e neste sentido “julgar”), elas emitem sim um juízo, muitas vezes mais contundente 
do que o realizado em decisões judiciais, que por sua natureza decidem caso a caso, sem emitir uma visão de conjunto das violações. ${ }^{51}$

\subsection{3) Anistias, Reparações e Reconciliação}

\section{Anistias}

Vários tribunais internacionais têm declarado que anistias violam a legislação internacional. Em 1998, o Tribunal Internacional para a Antiga Iugoslávia entendeu que anistias internas que cobriam crimes como tortura não teriam reconhecimento legal (Cf. Lutz, 2006). A Corte Interamericana de Direitos Humanos (CrIDH), a partir do caso Barrios Altos, também considerou que anistias que perdoam graves violações aos direitos humanos são incompatíveis com a Convenção Americana de Direitos Humanos (CADH).

Apesar de as anistias serem hoje bastante criticadas pela jurisprudência dos tribunais internacionais, a literatura sobre justiça de transição encontra argumentos favoráveis à concessão de anistias para alguns casos. Onde restaurar a paz, a segurança e a ordem são medidas necessárias para se evitar catástrofes humanitárias ainda maiores, as anistias podem ajudar a alcançar estes objetivos. Nestas situações, uma vez concedidas, elas precisam ser respeitadas, pois esta é a única garantia para as instituições começarem seu caminho de fortalecimento. A formação das instituições, aliás, é pré-requisito para o funcionamento das leis.

Esta questão surge, sobretudo, em transições pós-guerra. A Comissão da Verdade e Reconciliação de Serra Leoa, por exemplo, fez ponderações neste sentido. Ali realmente era muito forte a probabilidade da continuação dos conflitos, caso medidas confrontadoras fossem adotadas (Cf. Schabas, 2006). Em El Salvador, uma semana depois do processo de negociação conduzido pela ONU, embora este não tenha colocado explicitamente uma anistia como seu resultado, a Lei da Reconciliação Nacional foi publicada. Esta lei previa que toda responsabilidade criminal por crimes cometidos no conflito armado seria extinta. Também previa a extinção de outros crimes, mas não incluía genocídio, tortura e desaparecimento forçado nas suas disposições.

\footnotetext{
${ }^{51}$ Apoiado em Klaus Günther, Raphael Neves (2014) traça importante distinção entre accountability (ou responsabilização) e punição, para dizer que a primeira pode estar associada aos procedimentos das comissões da verdades, sendo que a segunda se aplica somente aos processos criminais.
} 
Experiências históricas e contemporâneas indicam uma relação próxima entre anistias e transformações liberalizantes. As anistias parecem preceder ou coincidir com o advento de políticas liberalizantes. Contemporaneamente, o leading case de anistia transicional é o da Espanha pós-Franco (Cf. Teitel, 2000, p. 54). Ali os processos criminais foram totalmente afastados ao mesmo tempo em que a democracia se consolidou rapidamente. Para autores importantes da ciência política, como Maravall e Santamaria (1991), o caso espanhol se tornou paradigmático do poder e conveniência deste tipo de anistia.

Por outro lado, outra lição a respeito das anistias é que elas raramente resistem para agentes estatais envolvidos com sérias violações aos direitos humanos. A anistia concedida no Peru, por exemplo, foi derrubada por decisão da CrIDH (Cf. Cueva, 2006). $\mathrm{O}$ indiciamento também do ex-presidente mexicano Luis Echeverría e outros oficiais pelo massacre de pelo menos 25 estudantes em protestos que ocorreram em 1971 no México é outro exemplo. Até então, os envolvidos gozavam de imunidades garantidas por décadas de acordos realizados dentro da coalizão governante do Partido Revolucionário Institucional (PRI). ${ }^{52}$

$\mathrm{Na}$ Argentina, depois dos processos contra comandantes da Junta Militar durante o governo Raúl Alfonsín, os militares mantiveram pressão sobre o governo, que então assinou a Lei do Ponto Final (1986), introduzindo os limites em que os processos poderiam ocorrer. Foi estabelecido um prazo de 60 dias para dar início aos processos, contados a partir da publicação da lei. Isso provocou uma correria por justiça, pois no prazo estabelecido organizações da sociedade civil e o Ministério tentaram encampar cerca de mil processos (Cf. Neves, 2014, p. 23).

Em 1987, o Congresso argentino aprovou também a Lei da Obediência Devida, que isentava da responsabilidade oficiais e soldados do baixo-escalão. Com o aprofundamento da crise econômica que assolava o país durante os anos 1980, Alfonsín renunciou ao cargo de presidente no último ano da década. Seu sucessor, Carlos Menem, concedeu vários perdões, inclusive a oficiais que já haviam sido condenados.

Depois de longo período de crise intensa, em 2003, Néstor Kirchner assumiu o governo. Embora eleito com apenas $22 \%$ dos votos, desenvolveu uma estratégia para pôr fim à impunidade de agentes do Estado envolvidos em sérias violações aos direitos humanos durante o período ditatorial no país. A iniciativa mais importante neste sentido

\footnotetext{
${ }^{52}$ Cf. Acosta e Ennelin (2006).
} 
foi anular ex tunc (com efeitos desde sua entrada em vigor) as duas leis de anistia (Ponto Final e Obediência Devida). Em 2005, quase 30 anos depois do golpe militar, a Suprema Corte, por 7 votos a 1, considerou as anistias inconstitucionais e afirmou a validade da lei que as revogava retroativamente (Cf. Sikkink e Walling, 2006).

Este processo possibilitou a reabertura de centenas de casos. Alfredo Astiz, por exemplo, conhecido como o Anjo Loiro da Morte, junto com outros 11 antigos militares e policiais, foram condenados por seu papel na execução de ativistas de direitos humanos que foram torturados na Escola Naval ESMA, e depois atirados de aviões no oceano (Cf. Neves, 2014, p. 24-25).

Em 1978, no Chile, o governo Pinochet outorgou anistia branca para crimes praticados por agentes do Estado entre 1973 e 1978. Depois da democratização, Pinochet conseguiu cadeira vitalícia no senado, o que lhe conferiu imunidade. O primeiro presidente a assumir o cargo após as primeiras eleições com o fim da ditadura militar, Patricio Aylwin, não revogou a anistia, mas criou a Comissão Nacional pela Verdade e Reconciliação. De acordo com Roht-Arriaza e Gibson (1998), esta Comissão elaborou um relatório com informações individualizadas de grande número de mortes e desaparecimentos e identificou os grupos responsáveis por estes atos. A anistia do Chile foi considerada duas vezes como constitucional e como compatível com a legislação internacional pela Suprema Corte do país. Entretanto, recentemente, em 2014, o Congresso chileno tem levado adiante um projeto de sua revogação. ${ }^{53}$

O argumento clássico em favor das anistias pode ser encontrado em Huntington (1991). Mas, neste caso, a proposição normativa está coberta pela descrição da realidade. O fato de que transições para a democracia são geralmente acompanhadas de anistias é transformado em um argumento normativo sobre a relação entre esta forma de clemência e a rule of law.

Nas discussões em geral sobre anistia pouco ou quase nada se lê sobre seus fundamentos mais gerais, para além da questão candente de uma transição, embora os temas da clemência e do perdão, por exemplo, sejam clássicos na filosofia ocidental. Quando falamos sobre anistia, raramente nos referimos aos elementos clássicos associados

\footnotetext{
${ }^{53} \mathrm{O}$ caso Almonacid Arellano v. Chile, que será comentado mais adiante, exerceu impacto sobre as iniciativas de revogação da anistia chilena. Mas apesar de sua manutenção até o momento, alguns membros das forças de segurança e militares foram condenados pela justiça criminal do país. Um dos argumentos que furou o bloqueio da anistia foi o de que o crime de desaparecimento forçado se trata de uma ofensa permanente, e que neste sentido não é coberta pelo escopo da anistia nem está sujeita à prescrição, pois a contagem de seu prazo sequer tem início enquanto o paradeiro do corpo do desaparecido não é descoberto.
} 
a ela. Quais são os padrões relevantes? Quem tem o poder de anistiar? Por qual princípio? Quais direitos e deveres estão implicados?

Do ponto de vista de uma teoria clássica, a anistia, assim como a punição, designa soberania, mostrando onde está o poder político (Cf. Bodin, 1992). Carl Schmitt (1995) também entende a concessão de anistia como um exercício do poder soberano. Mas, dentro de seu conceito de soberania, ele a enxerga como uma situação de suspensão das normas. Pelo fato de norma e realidade não disporem de uma conexão intrínseca, a norma pode ser colocada em suspenso enquanto é institucionalizada na realidade. Na medida em que a distinção entre uma situação normal e uma exceção é prerrogativa do soberano, as anistias seriam de sua competência. Do ponto de vista qualitativo, para Schmitt (1995, p. 219), as anistias são um ato recíproco de esquecimento. Já outros autores, como Peter Krapp (2005, p. 189), consideram que a anistia tende a ser elaborada justamente em casos em que ninguém pode ocupar a posição do soberano.

Esta concepção parece fazer mais sentido. Nas transições compactuadas, tanto os militares quanto a oposição política envolvida no conflito anterior tendem a ter interesse grande em assegurar sua própria imunidade: para garantir a própria, concordam em que o outro lado do conflito também a tenha. Este raciocínio é análogo ao desenvolvido por Ginsburg (2003) ao comentar o "modelo do seguro", em que vê maior probabilidade para a adoção de uma nova Constituição justamente em situações em que nenhuma das elites tem condições de dirigir o processo político e nem como prever que grupo social poderá ser dominante no futuro. Nestas situações, a adoção de uma Constituição para aumentar os custos de mudanças nos rumos da política por novas e futuras composições majoritárias passa a ser uma estratégia para garantir alguns dos interesses mais caros às elites em disputa.

Tecnicamente falando, o perdão sim, comentado por Hamilton (1984) no Federalista número 69, está ligado a um exercício regular do poder do soberano. Mas o perdão, diferentemente da anistia, além de ser veiculado em tempos de normalidade política e normativa, é concedido no nível individual, caso a caso, e não para grupos sociais ou políticos, como costuma ser o caso das anistias. ${ }^{54} \mathrm{Na}$ Constituição norteamericana, o direito de clemência é prerrogativa política do poder Executivo, de certa forma transportado da antiga prerrogativa da monarquia inglesa.

\footnotetext{
${ }^{54}$ Uma exceção é o modelo já comentado adotado pela Comissão da Verdade e Reconciliação da África do Sul, em que as anistias eram concedidas sob algumas condições e no nível individual, mas, de qualquer forma, no bojo de uma ampla política de concessão de anistias segundo critérios definidos em lei.
} 
Distinguindo-se desta situação, as anistias não são sancionadas por um poder soberano, nem mesmo as chamadas auto-anistias, pois estas são sancionadas por um poder em vias de se ver desinvestido da soberania.

\section{Reparações}

As reparações envolvem políticas tão amplas que mereceriam uma tese à parte. É o que International Center for Transitional Justice (ICTJ) e outras instituições geralmente fazem: publicam relatórios e artigos sobre as reparações em um documento, e em outro publicam relatórios e documentos sobre verdade e justiça.

Embora constituam recomendações comuns a praticamente todas as comissões da verdade, as reparações foram a princípio adotadas em poucos países e, quando adotadas, em escala pequena. Exceções são o Brasil (onde elas têm sido inclusive o eixo estruturante da justiça de transição, como veremos especialmente a partir do próximo capítulo desta tese), Argentina, Chile e África do Sul (em menor proporção). Com relação à América Latina, também foram criados programas recentes de compensações na Guatemala e no Peru (Cf. Roht-Arriaza, 2006).

Elster (2004, p. 127) afirma que, a fim de se compensar as vítimas, é preciso antes definir que formas de sofrimento constituem a "vitimicidade": se um sofrimento material (perda de propriedade ou do emprego, por exemplo), pessoal (violação da dignidade) ou intangível (perda de oportunidades), ou se dois ou mais tipos de sofrimento combinados. A comprovação de um dano simplesmente não serve como base exclusiva para justificar as reparações, pois sua extensão em regimes repressivos é praticamente insondável. $\mathrm{Na}$ verdade, o elemento relevante para discernir o objeto das reparações associadas à justiça de transição é antes a perseguição política. Conforme escreve Teitel (2000, p. 134): “As práticas de justiça transicional discutidas acima sugerem que o tipo de tratamento dado pelo Estado sujeito a oferecer compensações se relaciona primordialmente com discriminações do passado que assumiram caráter político". 55

A base de justificativas para as reparações são o direito natural e a legislação internacional, fontes de normas contínuas, não sujeitas a mudanças de regimes. $\mathrm{Na}$ literatura liberal, a violação do dever do Estado de proteger seus cidadãos é uma das

\footnotetext{
${ }^{55}$ No original: "Transitional practices discussed above suggest that past state treatment subject to compensation primarily relates to past discrimination on a political basis."
} 
razões que dão ensejo à revolução de um lado ou ao dever do Estado de indenizar seus cidadãos de outro.

De acordo com disposições de direito internacional, onde quer que o Estado tenha violado direitos dos cidadãos, existe um dever de reparação (Cf. United Nations, Economic and Social Council, 1993). As reparações também têm o sentido de corrigir a falha no princípio de equidade na proteção de direitos ensejada pelo regime anterior.

O Chile adotou um programa amplo de reparação vinculado aos trabalhos de sua Comissão da Verdade e Reconciliação. Com isso, mais uma vez, o Estado reafirmou sua responsabilidade pelas violações do passado. As reparações na Argentina, ainda que tenham experimentado um desenvolvimento pouco planejado e um tanto caótico, seriam ainda mais amplas e englobariam não apenas desaparecimentos, mas também prisões ilegais. Teitel (2000, p. 127) sustenta que, embora incipientes a princípio, as políticas reparatórias têm se tornado a resposta mais comum dos esforços de justiça transicional. Foi assim em El Salvador e na Guatemala, onde as reparações tiveram importante papel em fazer cessar os conflitos.

No entendimento da Corte Constitucional da África do Sul, as reparações eram elemento central para estimular a participação de vítimas em depoimentos na Comissão da Verdade e Reconciliação do país, ainda que, assim como a concessão de anistia, elas fossem condicionadas à avaliação da comissão sobre as violações ocorridas. Outras medidas de reparação também foram recomendadas no relatório final da Comissão. $\mathrm{O}$ Comitê de Reparação e Reabilitação, ligado à Comissão sul-africana, tinha a função de fazer as recomendações neste sentido, assim como adotar medidas de reabilitação da dignidade das vítimas. As recomendações eram enviadas ao presidente da Comissão, que as filtrava e repassava ou não ao Parlamento.

Entretanto, por conta do escopo da Comissão sul-africana, muitos tipos de violação ficaram de fora de sua avaliação, como remoções de comunidades e outras disputas rurais, além de discriminações praticadas no sistema de educação e em oportunidades de trabalho. As indenizações concedidas se limitaram a reparar violações relativas à integridade do corpo (Cf. Elster, 2004, p. 127).

\section{Reconciliação}

Segundo Roht-Arriaza (2006), na literatura sobre justiça de transição, a reconciliação era considerada ou como um código para a impunidade (sobretudo em 
relação às experiências na América Latina) ou como consequência do processo de revelação da verdade (aqui em relação à experiência na África do Sul).

Quando se fala em reconciliação, é impossível não lembrar da experiência sulafricana, que acabou por ser uma espécie de modelo para outras experiências justransicionais nas últimas décadas. A Comissão da Verdade e Reconciliação neste país tentou forjar um ambiente público para a expiação das violações dos dois lados do conflito que se deflagrou nas décadas finais do apartheid, as forças de segurança e os grupos armados paramilitares de oposição.

De acordo com algumas das leituras mais benevolentes sobre a experiência sulafricana neste sentido, como a de Duff et. al. (2007), o processo levado adiante pela Comissão da Verdade e Reconciliação deitou as bases para a criação de uma comunidade de cidadãos livres e iguais. Ao mesmo tempo em que chamava violadores para a responsabilidade, a Comissão dava voz às vítimas e procurava, por meio das audiências, promover sessões de catarse dos sofrimentos experimentados. Nesta visão, a justiça restaurativa foi provida como alternativa à justiça retributiva. Richard Wilson (2001) também mostra como a Comissão sul-africana usou o discurso dos direitos humanos para criar uma narrativa do perdão e da formação do Estado Nação sul-africano.

O termo "reconciliação", na verdade, foi substituído no relatório e na inspiração dos trabalhos da Comissão sul-africana pelo termo ubuntu. Retirado das línguas zulu e xhosa, trata-se de um conceito polissêmico que remete a compartilhar. Significa também que a humanidade de uma pessoa é inextrincavelmente ligada à humanidade dos outros. Quem possui ubuntu sabe que pertence a algo maior e se sente diminuído quando outros são humilhados, torturados ou oprimidos. De acordo com Neves (2014, p. 65), Desmond Tutu, presidente da Comissão, foi um dos que mais se esforçou para mostrar que a instituição que comandava era parte dos principais esforços de se unir o país. Em seu livro No Future Without Forgiveness, o bispo de Cape Town (Desmond Tutu, 2000, p. 73-74) sustenta que taxar os agressores de demônios equivaleria a jogar pela janela a accountability promovida pela Comissão, pois assim não se entende que os agressores também são sujeitos morais que podem ser e são responsabilizados por seus atos.

No entanto, também se pode considerar que o processo sul-africano foi muito peculiar, tanto em termos do tipo de autoritarismo anterior quanto em termos de transição. Pode-se pensar, por exemplo, em analogias entre a violência e os tipos de autoritarismo que tiveram lugar na África do Sul por um lado e em países da América do Sul, por outro. No entanto, essas são analogias na aparência, já que em todas essas experiências pode-se 
encontrar milhares de casos de torturas, desaparecimentos forçados e assassinatos. Mas estas experiências são muito diferentes em sua natureza e em suas raízes, já que uma se desdobrou no contexto do apartheid e da guerra civil sul-africanos; e as outras, no contexto das ditaduras da América do Sul com base na doutrina da Segurança Nacional.

O apartheid foi uma doutrina política e social baseada na segregação racial. Apesar do aumento das disparidades econômicas durante a ditadura, pelo menos no Brasil, não se poderia aplicar essa visão segregada da sociedade ao núcleo da doutrina da Segurança Nacional na América do Sul. A sociedade sul-africana estava até mesmo formalmente dividida em duas, e a violência estava intimamente ligada a esta divisão. Neste contexto, uma vez em que o apartheid como um sistema foi derrotado, a reconciliação acabou por ser o principal objetivo normativo da transição.

Além disso, importa salientar que Hayner (2011), por exemplo, desafia alguns entendimentos sedimentados no senso comum a respeito da reconciliação. Ela se pergunta se a implementação de políticas voltadas para o direito à verdade promovem ou não reconciliação. Levando em conta o contato que teve com várias vítimas e familiares durante os vários anos de suas pesquisas sobre comissões da verdade, Hayner atesta que o sentimento de reconciliação varia muito de pessoa para pessoa. Ela também relativiza a crença de que revelar a verdade e dar a chance para as vítimas falarem publicamente teria um efeito "curativo" ou catártico para as vítimas.

Neste mesmo sentido, Richard Wilson (2001) também assevera que o modelo presumivelmente catártico das audiências na Comissão da Verdade e Reconciliação da África do Sul passou a ser questionado por terapeutas. Evidências empíricas mostraram que testemunhar em público era experiência terapêutica para alguns, mas não para outros. Embora muito festejado internacionalmente, o modelo sul-africano foi bastante criticado no país. Apesar de apresentar muitos aspectos positivos, não levou necessariamente à reconciliação entre brancos e negros ou mesmo entre negros de diferentes grupos. Além disso, quase nenhum membro do alto escalão do governo anterior se dirigiu à Comissão para pedir anistia. E o Judiciário foi muito pouco assertivo com a possibilidade de persecução criminal nestes casos (Cf. Roht-Arriaza, 2006). Neste mesmo sentido, Erin Daly (2008) sustenta que a verdade produzida pelas comissões da verdade pode não ser muito bem aceita em sociedades altamente divididas, como a antiga Iugoslávia, a Palestina e o Iraque (o mesmo poderia ser dito a respeito da África do Sul, pelo menos até certo ponto). 
Estes contra-argumentos acerca do sucesso da Comissão sul-africana em gerar reconciliação ajudam a matizar e a tornar o quadro mais bem descrito e avaliado, mas não afastam o entendimento de que a experiência sul-africana foi de fato uma das mais bem sucedidas na tarefa de, ao mesmo tempo em que produzia responsabilização individual e elucidação da verdade, pelo menos não conduzia a sociedade ao colapso por meio de processos judiciais que poderiam levar ao encarceramento de milhares de pessoas (o que também seria inviável do ponto de vista administrativo).

A experiência sul-africana é importante e tem a ensinar a outras experiências, mas não exatamente como parte da literatura e do senso comum têm difundido. Afinal, de que reconciliação se tratava? O próprio relatório da Comissão considerava a reconciliação entre vítima e agressor como algo raro e difícil (Cf. Truth and Reconciliation Commission, 1998, capítulo 5, parágrafo 6). Em seu parágrafo 23, o relatório sustenta que a reconciliação não deve ser equiparada ao perdão, pois ela envolve, na verdade, um desejo mínimo de coexistência e de se lidar continuamente e pacificamente com as diferenças. O relatório também contava com uma parte intitulada "Reconciliation without forgiveness", que avaliava uma forma fraca de reconciliação.

A Comissão da Verdade e Reconciliação da África do Sul elaborou uma maneira criativa (embora nem sempre bem-sucedida) de responsabilizar os agressores, ao mesmo tempo em que manteve o objetivo de definir ambos os lados - agressor e vítima - como pares de uma mesma comunidade. Isso significa que eles não necessariamente apertariam as mãos depois de uma audiência onde um divulgou as violações que ele ou ela cometeu contra o outro ou contra um parente do outro, mas significa que, a partir deste procedimento, ambos poderiam se enxergar como compartilhando uma mesma comunidade, direitos e responsabilidades iguais, o que configura um mínimo de coesão para a vida em sociedade. Neste sentido, como defende também Pablo de Greiff (2012), a reconciliação não assume necessariamente o sentido de um acerto entre agressores e vítimas, mas de uma justiça corretiva reconhecida pela sociedade e mediada pelo Estado.

\subsection{4) A jurisprudência da Corte Interamericana de Direitos Humanos}

O Sistema Interamericano de Direitos Humanos é composto por dois órgãos, a Comissão Interamericana de Direitos Humanos (CmIDH) e a Corte Interamericana de Direitos Humanos (CrIDH) e está ligado à Organização dos Estados Americanos (OEA). A Convenção Americana sobre Direitos Humanos (CADH) traça o desenho institucional 
do Sistema (Cf. Hanashiro, 2001, p. 32). Neste sentido, mais do que dispor acerca de direitos e deveres, a Convenção estipula um mecanismo de compliance das garantias nela previstas, conferindo poderes cautelares ao Sistema, a fim de que os Estados Partes adotem medidas de direito interno com vistas a cumprir as disposições da Convenção.

Na América Latina, as transições para a democracia foram precedidas de décadas de ditaduras militares que envolveram milhões de sequestros, detenções, torturas e desaparecimentos, todas práticas levadas a cabo pela doutrina da Segurança Nacional. Revelações sobre os abusos que aconteceram no passado aguçaram depois das transições o sentimento de impunidade que os regimes sustentavam.

Nos primeiros anos de atuação do SIDH, praticamente toda a América Latina se via sujeita a regimes autoritários, o que prejudicava a própria submissão de casos ao Sistema. Nesta época (anos 1980 e início dos 1990), as atividades mais destacadas dos membros do Sistema consistiam em realizar visitas a centros de detenções sujeitos a sérias denúncias de violações aos direitos humanos, a fim de aumentar a visibilidade das vítimas e escancarar o terrorismo de Estado.

Mas ainda não haviam condições geopolíticas para uma atuação combativa do Sistema, e sobretudo da Corte, no sentido de atribuir responsabilidades ou mesmo arbitrar medidas de compensação material às vítimas. A Corte estava mais envolvida com a preservação de liberdades civis e políticas, como a concessão de habeas corpus, a garantia da liberdade de imprensa, do devido processo legal etc (Cf. Hanashiro, 2001, p. 57). Mas mesmo nestes casos, tratava-se ainda do exercício de uma jurisdição meramente consultiva, e não contenciosa, pela Corte.

O recebimento dos primeiros casos contenciosos coincidiu, não por acaso, com a redemocratização no continente. No que se refere à jurisprudência da Corte relativa ao que mais tarde ficaria conhecido como justiça de transição, o leading case mais paradigmático foi Velásquez-Rodrigues versus Honduras, decisão de 1988. Velásquez-Rodríguez desapareceu em Honduras nos anos 1980, sendo que o país falhou em investigar seu paradeiro. A propósito da investigação que levou ao processo junto à $\mathrm{CrIDH}$, ficou claro que seu desaparecimento tinha sido fruto de ação estatal. A decisão sobre este caso deitou uma série de paradigmas jurisprudenciais na Corte, desde a responsabilidade criminal de agentes do Estado, passando pelo direito das famílias à verdade e o dever do Estado de reparar o dano causado. A partir deste caso, a Corte lançou as bases do entendimento segundo o qual os Estados devem prevenir, investigar, processar e julgar violações dos direitos reconhecidos na Convenção, e reparar os danos (Cf. Teitel, 2000, p. 124). 
Alguns anos mais tarde, em outro caso paradigmático de sua jurisprudência, o caso Niños de la Calle, a Corte declarou que a continuidade da impunidade também configurava uma ofensa aos direitos humanos (Cf. Lima, 2012, p. 201). A mesma coisa ocorreu no caso Blake versus Guatemala, em que os argumentos usados pela Corte poderiam ser resumidos da seguinte forma: 1) a falha do Estado em desvendar o destino de uma pessoa sob sua custódia constitui tratamento inumano em relação a membros da família. Neste sentido, a insistência nesta falha é uma violação contínua ao artigo 5(1)(2), combinado com artigo 1.1 da CADH. 2) A falha do Estado em investigar e processar crimes cometidos contra uma pessoa sob sua custódia constitui uma violação do direito da família de ter acesso à justiça (Cf. Groome, 2011, 177).

Com base essencialmente nestes argumentos, a Corte tem exigido dos Estados latino-americanos uma resposta satisfatória a graves violações aos direitos humanos. $\mathrm{O}$ caso Blake também mostra que o direito à verdade, na opinião da Corte, é parte do direito de se ter acesso ao processo judicial.

Um passo adiante na conformação da jurisprudência da Corte acerca da justiça de transição foi a decisão do caso Barrios Altos versus Peru (CrIDH, 2001), que considerou as leis de anistia que perdoam graves violações aos direitos humanos como incompatíveis com a CADH. Embora inicialmente contrário à determinação da Corte, o Peru acolheu sua responsabilidade internacional. O parágrafo 143 da decisão determinou:

\begin{abstract}
"A Corte julga necessário enfatizar que, à luz das obrigações gerais consagradas nos artigos 1.1 e 2 da Convenção Americana, os Estados Partes têm o dever de tomar todo o tipo de medida para que ninguém seja privado da proteção judicial e do exercício do direito a um recurso simples e eficaz, nos termos dos artigos 8 e 25 da Convenção. É por isso que os Estados Partes da Convenção que adotem leis que tenham esse efeito, como são as leis de autoanistia, incorrem em violação dos artigos 8 e 25 , em conformidade com os artigos 1.1 e 2 da Convenção. As leis de autoanistia levam ao desamparo das vítimas e à perpetuação da impunidade e por isso são manifestamente incompatíveis com a letra e o espírito da Convenção Americana. Esse tipo de lei impede a identificação dos indivíduos responsáveis por violações a direitos humanos, já que obstrui a investigação e o acesso à justiça e impede que as vítimas e seus familiares conheçam a verdade e recebam a reparação correspondente" (CrIDH, 2001).
\end{abstract}

A Corte também se referiu à incompatibilidade de outras excludentes de punibilidade, como a prescrição e a irretroatividade da lei penal mais severa, com a Convenção. É justamente da combinação entre os artigos 8 e 25 , mencionados no trecho acima citado, que a Corte extrai seu entendimento acerca do dever do Estado de punir os 
violadores e acerca do direto das vítimas à revelação da verdade. Mas em sua visão, a verdade seria produzida sobretudo por meio dos processos judiciais. $\mathrm{Na}$ esteira do aprofundamento desta visão penalista a respeito da justiça de transição, no caso Zembrando Vélez e outros versus Equador, a Corte sustentou que as comissões da verdade não constituem uma alternativa ao processo penal no sentido da responsabilização individual dos agressores (Cf. Lima, 2012, p. 206).

Alguns anos mais tarde, já em 2006, no caso Almonacid Arellano, não só as autoanistias passaram a ser consideradas como inválidas pela Corte para isentar da responsabilidade penal agentes do Estado, mas toda e qualquer anistia neste sentido, uma vez que, segundo seu entendimento, as normas da Convenção proibindo tortura, desaparecimentos forçados, homicídios e outros crimes graves seriam regras de jus cogens, isto é, inderrogáveis mesmo por decisão democrática em contrário (Cf. Binder, 2011). Neste julgamento, a Corte também mostrou sua visão bastante crítica sobre o papel de comissões da verdade como forma de responsabilização. No parágrafo 150 da decisão, lê-se: “a 'verdade histórica' contida nos informes das citadas comissões não pode substituir a obrigação do Estado de revelar a verdade através dos processos judiciais" (CrIDH, 2006).

Em 2011, a CrIDH também entendeu que a anistia uruguaia violou a CADH por não permitir a investigação, julgamento e punição dos que mataram e foram responsáveis pelo desaparecimento forçado de María Claudia Gelman. De modo similar a outros casos, a Corte decidiu que as anistias são ilegais porque impedem os Estados de processar e condenar agressores. Mas dessa vez a Corte teve que lidar com o fato de que a Lei de Caducidade havia sido ratificada por duas consultas populares, um referendo em 1989 e um plebiscito em 2009 (Cf. Roniger, 2011). Diante desta situação, a Corte argumentou que o aspecto substancial da democracia, a decisão da maioria, atropelou um de seus limites formais estabelecido pela legislação internacional, que deve ser observada por todos os poderes do Estado, não apenas o Judiciário.

Em sua avaliação sobre a jurisprudência da CrIDH, Basch (2007, p. 207) se refere àqueles que seriam os três pilares da atuação da Corte no âmbito da justiça de transição: o dever dos Estados de punir todas as violações aos direitos humanos; a rejeição de praticamente qualquer instituto jurídico que exclua a punibilidade dos agentes do Estado (tais como irretroatividade da lei penal mais severa, prescrição, anistia, perdão etc); e a prioridade aos direitos das vítimas em oposição aos direitos dos réus. Neste sentido, a preocupação teleológica da justiça criminal no âmbito da justiça de transição, com vistas, 
por exemplo, à consolidação da rule of law, ficaria cada vez mais distante na jurisprudência da Corte Interamericana para dar lugar ao entendimento de que a punição dos violadores é direito inalienável da vítima e obrigação do Estado (mesmo à revelia de excludentes de punibilidade).

A consolidação do entendimento jurisprudencial da Corte e sua grande repercussão nos países da América Latina têm influenciado a visão de vários atores na região sobre o tema (Cf. Malarino, 2007). Hoje é possível identificar a utilização do vocabulário e da estrutura argumentativa da Corte por vários grupos de ativistas em direitos humanos, não só na região, e até mesmo por juízes e outros operadores do direito.

Entretanto, em vista do que considera como alguns exageros na visão penalista da Corte, Lima (2012, p. 213) se questiona se ainda se sustenta um dos pilares que diferenciam os julgamentos políticos dos judiciais: os direitos e garantias fundamentais dos acusados. Na mesma linha, Basch (2007, p. 213) chama a atenção para uma possível emergência de um "direito penal do inimigo", que se vale da figura do perpetrador para afastar garantias processuais dos réus.

\section{Considerações finais do capítulo}

Embora classificada como uma justiça (seja ordinária ou extraordinária) inserida em circunstâncias extraordinárias que sempre implicariam um grau maior de imperfeição em sua aplicação, o fato é que, nas experiências mais bem sucedidas de articulação entre os diferentes mecanismos de justiça de transição, mais dimensões da justiça ${ }^{56}$ são atendidas do que em procedimentos civis ou penais da Justiça Comum. Nesta, geralmente, há ou apenas uma reparação econômica ao indivíduo lesado ou apenas uma sanção penal ao violador, ainda que se trate de casos de violências que, no nível individual (isto é, sem se considerar a característica sistêmica das perseguições políticas), podem ser tão hediondas como as violências aplicadas pelo aparato repressivo contra seus opositores. ${ }^{57}$

\footnotetext{
${ }^{56}$ Como a dimensão corretiva nas reparações e nos procedimentos de revelação pública da verdade e a dimensão retributiva em eventuais condenações de violadores de direitos humanos.

${ }^{57}$ Também existe a possibilidade, na Justiça Comum, de se perseguir uma indenização civil paralelamente ou subsequentemente a uma condenação penal do agressor, mas esta possibilidade não é considerada pelo direito e legislação dos países como parte de uma teoria da responsabilidade e/ou da responsabilização tão fortemente amarrada como a necessidade normativa de atendimento aos diferentes mecanismos da justiça de transição, na qual se considera, inclusive, como vimos, que o não atendimento de um mecanismo pode
} 
Não é bem este o caso brasileiro, pois, se tem havido avanços nos diferentes mecanismos da justiça transicional, eles ocorreram - como veremos com mais detalhes nos próximos capítulos - de forma fragmentada no tempo e institucionalmente, e a dimensão reparatória ganhou inegável destaque em relação às outras medidas, sobretudo em relação à justiça criminal. Porém, em outros casos, como talvez no Chile (também uma experiência imperfeita, mas que contou com uma implementação e uma articulação maior entre os mecanismos), esta hipertrofia da afirmação da justiça (não no sentido ideal, mas comparativamente falando em relação à Justiça Comum) pode bem ser notada.

Isso só pode ser explicado pela dimensão simbólica da justiça de transição, associada que está com uma representação fundacional de um novo regime e com a ruptura em relação ao autoritarismo e à violência institucional do passado. Isto é pouco destacado pela literatura, que esteve engajada, inclusive, nas últimas formulações teóricas da justiça de transição, em mostrar que se trata de uma aplicação da justiça comum, ordinária, ou de uma justiça "sem adjetivos" (não de uma justiça “extraordinária”) em circunstâncias peculiares.

Concordo com esta afirmação, mas isso não significa então que deveríamos necessariamente associá-la à Justiça Comum de modo a torná-la corriqueira e naturalizada, pois neste caso o campo perderia muito de sua dimensão simbólica. Isso também não significa que não se deva recorrer à Justiça Comum para levar a efeito as dimensões normativas do campo, mas que, mesmo neste caso, é preciso deixar claro que se trata de uma demanda que possui uma dimensão simbólica extraordinária (embora não seja, de fato, uma justiça extraordinária).

Julgamentos de notáveis associados ao regime repressivo anterior têm historicamente um apelo fundacional. São bastante conhecidos os julgamentos de Carlos I no curso das Revoluções Inglesas do século XVII e de Luís XVI no curso da Revolução Francesa, mais de um século mais tarde. Os regimes autoritários são geralmente definidos e lembrados por suas características de transgressão promovidas pelo Estado. É por isso que a atribuição de responsabilidade criminal a lideranças do regime anterior por suas práticas ilegais e legislações injustas e arbitrárias assume tal dimensão desde a Grécia 
Antiga, passando pelos julgamentos de Carlos I, Luís XVI e os Tribunais de Nuremberg e Tóquio, dentre muitos outros exemplos. ${ }^{58}$

Argumentos clássicos em favor dos processos de responsabilização (geralmente e historicamente criminal) em situações normais remetem à retribuição da ofensa ao agressor, à proteção da sociedade de seu potencial danoso, bem como à tentativa de ressocialização (Cf. Beccaria [1769], 1975). No caso da justiça de transição, a função da responsabilização adquire dimensões ainda maiores, pois inclui entre suas tarefas desenhar uma linha divisória entre o passado arbitrário e o presente, em que a rule of law passa a vigorar (Cf. Teitel, 2000, p. 28).

A justiça de transição assume um processo de deslegitimação (simbólica e funcional) do regime anterior e de definição do que significa injustiça na atuação do Estado. Ela tem a função de catalisar a identidade social em torno de um novo paradigma normativo no qual a rule of law teria absoluta primazia.

O julgamento de Luís XVI foi definitivo para a caracterização da mudança de regime, pois com ele o monarca deixou de estar acima da lei, para também sujeitar-se a ela. A distinção central entre monarquia (absoluta) e república é justamente esta: apenas na última há isonomia perante a lei (Walzer, 1974, p. 78). ${ }^{59}$ A não ser que o regime anterior tenha ruído sobre seus próprios pés, como ocorreu de certo modo na ditadura militar argentina, é muito provável que a ideologia que o sustentava permaneça resiliente no regime sucessor.

Neste sentido, não basta a derrota política do regime anterior, mas é preciso alcançar seu descrédito social. Por isso que, para Thomas Payne (1974, p. 129), a questão sobre levar ou não o rei Luís XVI a julgamento era uma oportunidade de se estabelecer uma verdade sobre a monarquia. Teitel (2000, p. 73) afirma que outros julgamentos antológicos, recentemente, especialmente em Nuremberg e na Argentina, serviram mais para criar uma memória duradoura sobre a tirania do que gerar "punições exemplares". 60

Até hoje os julgamentos de Nuremberg são fontes tidas como altamente confiáveis por historiadores que pesquisam o passado de atrocidades nazistas. O julgamento de 1983 da junta militar da Argentina também tornou público o passado do país. Os eventos

\footnotetext{
${ }^{58}$ Sobre o julgamento de Carlos I, ver David Lagomarsino e Charles T. Wood (1989); e sobre o julgamento de Luis XVI, ver Michael Walzer (1974).

${ }^{59}$ Outro argumento neste sentido pode ser encontrado em Otto Kirchheimer (1961).

${ }^{60}$ Apesar disso, Teitel (2000, p. 115) assevera que a justiça de transição assume mais uma característica transicional do que fundacional. Teitel faz esta distinção a partir de uma concepção sua muito restrita de fundação, na medida em que, para ela, o termo remete aos processos de formação dos Estados Nação, que em geral se passaram em épocas bastante anteriores aos processos de redemocratização.
} 
terríveis da repressão política foram divulgados e discutidos amplamente a propósito destes julgamentos. A mídia e o público ainda se debruçaram sobre o processo por bastante tempo.

Por isso que importará, nos próximos capítulos, tentar desvendar que tipo de discursos fundacionais seria possível encontrar no percurso da justiça de transição brasileira. Políticas de justiça transicional, talvez mais do que qualquer outro campo de políticas públicas, ajudam em alguma medida a definir um auto-entendimento da experiência do novo regime - e isso se dá em grande parte em contraste com o que se passou antes. Trata-se de um exercício - levado a efeito pelo Estado em cooperação ou a partir de pressões da sociedade civil - de auto-compreensão dos fundamentos e objetivos essenciais de seu regime político. 


\section{Capítulo 2. A anistia e o programa brasileiro de reparações}

Este e os próximos dois capítulos têm por escopo as principais políticas públicas e a jurisprudência envolvidas no processo justransicional no Brasil. Obedecendo a divisão didática por "eixos" ou "mecanismos" de justiça de transição, bem como uma certa cronologia do processo no país, a ideia será recuperar criticamente, no presente capítulo, o desenvolvimento da anistia entre o final da década de 1970 até os dias atuais e o chamado "programa brasileiro de reparações", que envolve os trabalhos da Comissão Nacional de Anistia e da Comissão Especial sobre Mortos e Desaparecidos Políticos (CEMDP). No capítulo seguinte, o eixo "justiça" será o foco central, com atenção especial à jurisprudência de Tribunais brasileiros a respeito de demandas - principalmente, mas não exclusivamente - na esfera penal. O último capítulo cuidará da criação e dos trabalhos da Comissão Nacional da Verdade.

Com relação à reforma das instituições - que seria o quarto eixo de políticas públicas de justiça de transição -, é impossível recuperar neste trabalho seus aspectos mais importantes, que são abordados por uma imensa literatura em Ciência Política, a qual possui, inclusive, diferentes correntes e perspectivas. De qualquer forma, vale destacar que a democracia brasileira - instaurada fundamentalmente com o marco legal e institucional da Constituição Federal de 1988 - tem alto grau de representatividade em suas instâncias legislativas (que motivam, inclusive, críticas sobre certo excesso de consociativismo). Além disso, apenas para citar mais alguns dos principais aspectos das reformas institucionais por que passou o país desde a redemocratização, a literatura sobre o presidencialismo de coalizão atesta a governabilidade do país pautada em alianças. A independência do Judiciário e do Ministério Público também têm refletido uma maior 
exigência de accountability dos órgãos da Administração Pública. As liberdades de imprensa e de manifestação também têm um espaço que provavelmente nunca tiveram antes na história do país. Enfim, são muitos os aspectos dignos de nota que apontam para um alto grau de consolidação e de aprofundamento dos direitos políticos e de sua proteção no Brasil. ${ }^{1}$

Apesar de já haver uma literatura razoável a respeito da anistia e do programa brasileiro de reparações ${ }^{2}$, na medida em que este tem, especialmente a partir de 2007, extrapolado as fronteiras das indenizações para se transformar, sobretudo no caso da Comissão de Anistia, no principal promotor da "memória" (do ponto de vista das políticas de Estado), aspectos importantes da nova dinâmica das comissões de reparação não fizeram parte do escopo de muitos dos textos desta literatura. ${ }^{3}$ Além disso, também a partir de 2007/2008, boa parte da produção acadêmica que faz um trabalho de reflexão sobre as atividades das comissões de reparação passou a ser assinada por integrantes ou ex-integrantes destas próprias comissões, os quais certamente têm contribuído enormemente para uma espécie de internalização do debate sobre justiça de transição no Brasil. Mas uma abordagem de quem não esteja diretamente envolvido com as atividades destas comissões, apesar de não poder ombrear com a abrangência dos vários textos produzidos por seus integrantes ou ex-integrantes, pode contribuir, ainda que modestamente, para uma crítica construtiva ao programa brasileiro de reparações. ${ }^{4}$

\footnotetext{
${ }^{1}$ Mesmo em termos comparativos, de acordo com o índice da Freedom House Political Rights, o Brasil desponta com um dos mais altos índices de qualidade democrática, muito superior ao desempenho relativo do país, por exemplo, no Índice de Desenvolvimento Humano (IDH).

2 Em oposição aos mecanismos "justiça" e "verdade" da justiça de transição brasileira, os quais, por sua relativa novidade, ainda carecem de um número maior de abordagens mais aprofundadas.

${ }^{3}$ Como, por exemplo, Adriana Loche (2003), Heloisa Greco (2003), Anthony Pereira (2005), Glenda Mezarobba (2006 e 2007), Janaína Teles (2005) e Edson Teles (2007).

${ }^{4}$ Nos últimos anos, sobretudo a Comissão Nacional de Anistia e seus integrantes começaram a produzir profusamente uma série de textos didáticos, históricos e acadêmicos sobre justiça de transição. Apenas para citar alguns dos autores mais engajados na produtividade acadêmica, vale destacar alguns dos textos que escreveram juntoso presidente da Comissão de Anistia e seu ex-coordenador de projetos, respectivamente, Paulo Abrão e Marcelo Torelly $(2010,2011,2012)$, ou separados (Paulo Abrão e Tarso Genro, 2012; e Marcelo Torelly, 2012), bem como José Carlos Moreira da Silva Filho (2010), vice-presidente da Comissão de Anistia. Marcelo Torelly também era coordenador geral da Revista Anistia Politica e Justiça de Transição, publicação semestral financiada pelo Ministério da Justiça desde 2009. A profusão de textos produzidos por estes autores é tão grande que sepode dizer que constituem uma espécie de "militância acadêmica" a partir da Comissão de Anistia.
} 


\section{1) Anistia}

Conforme já foi ressaltado na introdução deste trabalho, a principal proposta é analisar o discurso de agentes de políticas públicas, ministros, magistrados e governantes envolvidos com a justiça de transição no país. Por isso, neste texto, apenas por uma questão de objetividade em relação ao escopo da pesquisa, será dada maior atenção às políticas e discursos de agentes públicos do que propriamente às atividades da sociedade civil em torno do tema. Esta ressalva é importante para deixar claro que a atenção maior concedida às políticas de Estado não corresponde, necessariamente, a uma relevância maior de sua atuação frente à sociedade civil. Trata-se de uma questão de objeto e recorte de pesquisa. Além disso, considerando sobretudo a amplitude das políticas de reparação (que também foram realizadas em nível estadual em algumas regiões), da jurisprudência e mesmo as inúmeras comissões da verdade de caráter regional e local que foram criadas no país nos últimos anos, também por uma questão de recorte de pesquisa o objetivo aqui será dar prioridade a estas formulações no nível da União (isto é, na esfera federal).

\subsection{1) Origens sociais da luta por anistia e o projeto governista}

Segundo Heloisa Greco (2003), a palavra “anistia" engloba os conceitos de anamnesis (reminiscência) e amnésia (olvido, perda total ou parcial da memória). A primeira anistia política teria sido instituída no Ocidente, em 403 a.C., em Atenas, concedida pelos insurgentes democratas a seus inimigos vencidos a propósito da restauração da democracia. Desde então, segue a autora pautada em Loraux (1992), é comum que se faça certa consideração sobre a democracia como um governo moderado. Historicamente, uma literatura tradicional sobre as anistias as identificava a um meio de pacificação dos espíritos e de distanciamento em relação à possibilidade da vingança privada.

Mais recentemente, entretanto, a literatura convencionou operar uma distinção entre diferentes formas de anistia, nomeando de "anistias em branco" aquelas editadas ainda sob o poder autoritário ou sob sua forte influência e que têm por objetivo garantir a impunidade de agentes repressores. Estas "anistias em branco", muito comuns na América Latina, foram publicadas em geral antes do recente reforço no direito internacional dos 
direitos humanos com a criação dos Tribunais internacionais a partir dos anos 1990 (Cf. Bastos, 2009).

No Brasil, um dos primeiros movimentos a organizar manifestações e reivindicações de anistia nos anos 1970 foi a Frente Ampla, que reunia personalidades políticas das mais diversas vertentes, como Carlos Lacerda, Juscelino Kubitschek e João Goulart, entre outros. Depois do AI-5 e a subsequente generalização da prática da tortura, o movimento por anistia engrossou. A partir de 1968, uma parte da cúpula progressista da Igreja Católica, como Dom Hélder Câmara e Dom Paulo Evaristo Arns, além de brasilianistas e entidades internacionais, como a Organização dos Estados Americanos (OEA) e a Anistia Internacional, também passaram a denunciar a tortura e a clamar por uma anistia no país. Depois do AI-5 e a subsequente generalização da prática da tortura, o movimento por anistia ganhou força. No início da década de 1970 surgiu também o Movimento Feminino pela Anistia, que conseguiu reunir assinaturas de 20 mil mulheres de todo o país para endossar a pressão da sociedade civil sobre o governo a fim de se elaborar um projeto de anistia que satisfizesse as demandas destes movimentos (Cf. Mezarobba, 2006, p. 25).

Em 1975, as mortes suspeitas de Vladimir Herzog e de João Goulart, este no exílio, ajudaram a dar publicidade à tortura e ao movimento pela anistia, levando à sua ampliação. Cresceram as manifestações estudantis e as comunidades eclesiais de base e outros movimentos populares também passaram a reivindicar a pauta. Por outro lado, a ditadura brasileira também perdia força nas relações internacionais: entre outros fatores, Jimmy Carter, presidente dos Estados Unidos entre 1977 e 1980, inverteu a posição de apoio do país aos regimes militares na América Latina e passou a defender discursos em favor dos direitos humanos (Cf. Mezarobba, 2006, p. 28).

Em 1978, surgiu outro importante movimento, o Comitê Brasileiro pela Anistia (CBA), no Rio de Janeiro, composto por advogados, exilados, amigos e familiares de presos políticos. Segundo Mezarobba (2006, p. 29), a Carta de Princípios lançada por este grupo pedia o perdão imediato de todos os presos e perseguidos políticos, mas sem estender o pedido aos "algozes de suas vítimas". Também propugnava pelo fim da tortura, pela libertação dos presos políticos, pela restituição dos direitos políticos e pelo retorno dos exilados, bem como pela revogação da Lei de Segurança Nacional, que condensava em termos jurídicos a Doutrina da Segurança Nacional, núcleo da ideologia dos militares à frente do poder no período. 
Durante o encontro nacional de movimentos pela anistia que tomou lugar em 1978, em Salvador, os grupos engajados na luta pela anistia elaboraram e divulgaram um documento conhecido como "Carta de Salvador". Nele era defendida uma anistia "ampla ('para todos os atos de manifestação de oposição ao regime'), geral ('para todas as vítimas dos atos de exceção') e irrestrita ('sem discriminações ou restrições')” (Mezarobba, 2006, p. 31). Nos termos do movimento, então, a anistia "ampla, geral e irrestrita" se referia a todos aqueles engajados na oposição ao regime militar. Não se cogitava incluir os próprios agentes do Estado engajados na repressão. Apenas mais tarde o discurso favorável à anistia nos termos dos militares construiria a interpretação segundo a qual a anistia ampla, geral e irrestrita seria o mesmo que a anistia recíproca, e neste sentido forjar-se-ia a imagem de que a lei tal como essencialmente elaborada pelo governo Figueiredo teria atendido à demanda popular. A campanha nacional promovida pelo CBA também levantava a bandeira da elucidação da verdade sobre os desaparecidos e a apuração de responsabilidades com a identificação e localização dos mortos na Guerrilha do Araguaia. No final da década de 1970, o movimento pela anistia realizava provavelmente a maior mobilização social da história brasileira até aquele momento, a qual seria superada mais tarde apenas pelas Diretas Já.

Neste contexto, também a partir dos anos 1970 alguns projetos de anistia foram elaborados no Congresso Nacional, a maioria da oposição. Porém, um importante óbice se colocava diante da tramitação destes projetos: a Emenda Constitucional $\mathrm{n}^{\mathbf{0}}$ 1, de 1969, para muitos analistas praticamente uma nova Constituição da ditadura militar, previa que projetos atinentes a anistias seriam de iniciativa exclusiva do Executivo.

Em 1979, o governo Figueiredo finalmente resolveu dar uma resposta à pressão popular que inflacionava em torno da anistia. O projeto que viria a ser formulado estava incluído no contexto mais amplo da chamada "distensão" ou "abertura", uma espécie de transição para a democracia que seria controlada pelos próprios militares, os quais não queriam abrir mão de seus interesses mais caros no processo. O período, cujo início é associado à assunção de Geisel ao poder em 1974, contou com, entre as principais medidas no sentido da "distensão": a realização, no mesmo ano, de eleições livres para deputados, senadores e vereadores (o que não ocorria desde o golpe, dez anos antes); a revogação do AI-5 e outros Atos Institucionais em 1978; o retorno do pluripartidarismo e a própria anistia em 1979; as eleições diretas para governador em 1982; dentre outras medidas. 
Entretanto, durante este mesmo período, várias medidas de recrudescimento da "abertura" foram adotadas pelos dois últimos governos militares, a fim de temperar o tempo e a profundidade da transição. Entre as medidas mais conhecidas de recrudescimento estão o Pacote de Abril, de 1977, que, entre outras coisas, permitia ao partido situacionista referendar a indicação pelo presidente de um terço dos senadores (os chamados "senadores biônicos", a fim de conter o sucesso eleitoral da oposição em 1974); e a Lei Falcão, que um ano antes mudava radicalmente o formato das propagandas eleitorais transmitidas por veículos de comunicação em massa (também visando a conter o avanço da oposição). Além disso, em meados dos anos 1970, a luta armada ainda acabava de ser aniquilada, e dirigentes de partidos (clandestinos) de esquerda que não haviam se envolvido diretamente com as guerrilhas urbanas ou rurais passavam a ser o alvo privilegiado dos homicídios e desaparecimentos forçados praticados pelas forças de segurança (Cf. CEMDP, 2007). ${ }^{5}$

É nesta chave de "abertura" e recrudescimento que precisa ser lido o projeto de anistia do governo, que, praticamente inalterado, seria aprovado pelo Congresso em 1979.

Tendo em vista tanto seu projeto de abertura controlada quanto a grande pressão popular pela aprovação de uma anistia, a Presidência tratou de elaborar um projeto que teve em Petrônio Portela seu principal porta-voz. ${ }^{6}$ Ernani Satyro, que fora ministro do Superior Tribunal Militar (STM) e era deputado pela Arena, passou a figurar como o parecerista do governo na Comissão que realizava os trabalhos e coordenava as discussões em torno do projeto. Ele propôs algumas alterações que, em geral, ampliavam um pouco o escopo do texto original. Suas propostas foram aprovadas na Comissão e em seguida aceitas pelo plenário do Congresso (Cf. Mezarobba, 2006, p. 45 e seguintes).

Satyro afirmou na época que os direitos patrimoniais dos anistiados seriam assegurados, mas o retorno à ativa dependeria da existência de vagas nas repartições, do interesse da Administração Pública e da constatação de que o afastamento não tinha sido motivado por improbidade do servidor (Cf. Mezarobba, 2007, p. 113). Com relação aos desaparecidos, o artigo $6^{\circ}$ do diploma legal ao final aprovado apenas falava em

\footnotetext{
${ }^{5}$ A partir de 1975, quando remanescentes alguns poucos guerrilheiros, os dirigentes do PCB passaram a ser o alvo privilegiado das mortes e desaparecimentos. Mas outros oposicionistas também seriam vítimas destas práticas na última década do regime autoritário.

${ }^{6}$ Petrônio Portela fora presidente do Senado e era líder da Arena no Congresso. Além dele, participaram da elaboração do projeto o general Golbery do Couto e Silva, então ministro-chefe da Casa Civil e um dos maiores ideólogos da Doutrina da Segurança Nacional, Octávio Aguiar de Medeiros, chefe do Serviço Nacional de Informações (SNI), Danilo Venturini, chefe do gabinete militar, e Heitor Ferreira, secretário particular do Presidente Figueiredo.
} 
"declaração de ausência" para gerar presunção de morte via sentença judicial com o objetivo de se liberar entraves relativos ao direito de herança dos familiares.

A previsão de anistia também para os agentes de Estado que praticaram crimes não poderia ser explícita na lei porque o próprio governo militar negava, fundamentalmente, a prática da grande maioria dos crimes denunciados pela oposição, e, de outra parte, com relação ao combate das guerrilhas armadas, por exemplo, considerava sua atuação como plenamente "legal". Mesmo assim, ardiloso, o projeto visava a encetar a possibilidade de uma interpretação que considerasse também os agentes públicos como beneficiários da lei para o caso de no futuro se considerar como antijurídicos os atos por eles praticados. Esta é a razão do parágrafo $1^{\circ}$ do artigo $1^{\circ}$ da lei, que estende seus benefícios a "crimes conexos"?

O projeto substitutivo do MDB foi derrotado por margem de 15 votos (209 a 194). E a Emenda Djalma Marinho, que previa anistia para todos os perseguidos políticos, foi derrotada por margem de apenas cinco votos (206 a 201). Apesar de o projeto do MDB e as reivindicações dos movimentos sociais não terem sido acatados em sua maioria, a lei finalmente aprovada representava já uma vitória importante, ainda que parcial, da luta pela expansão dos direitos civis e políticos em direção à redemocratização. No mínimo, a força dos movimentos sociais constrangeu o governo militar a tal ponto que não seria mais possível não sair-se com uma lei de anistia, por parcial e problemática que fosse.

A lei deixou de fora da anistia os praticantes de "terrorismo", assalto, sequestro e atentado pessoal (parágrafo $2^{\circ}$ do artigo $1^{\circ}$ da Lei de Anistia, $n^{\circ} 6.683 / 1979$ ). Na época da tramitação do projeto do governo no Congresso, muitos movimentos pela anistia manifestaram críticas ferrenhas, sobretudo em relação à pequena abrangência da anistia entre os opositores do regime e ao fato de que ela isentava de responsabilidade penal os agentes do Estado que teriam praticado os chamados "crimes conexos". Mesmo a Ordem dos Advogados do Brasil (OAB), já na época, sugeriu várias emendas ao projeto do governo (Cf. Mezarobba, 2006, pp. 42 a 44).

Neste mesmo sentido, ainda em 1979, carta assinada por 23 familiares de vítimas da repressão - e entregue ao senador Teotônio Vilela pouco depois da edição da Lei de Anistia - criticava a parcialidade e as graves limitações do documento legal (Cf. Mezarobba, 2007, p. 37). Segundo Janaína Teles (2005), a anistia do governo atendia às demandas dos exilados, imensa maioria das vítimas da repressão, mas não às demandas de

\footnotetext{
${ }^{7}$ Uma discussão mais aprofundada a respeito será feita no próximo capítulo.
} 
torturados e de familiares de mortos e desaparecidos políticos, encetando uma certa divisão no antigo movimento entre avaliações positivas (ainda que críticas) e negativas sobre a anistia formulada pelo governo Figueiredo. As diferenças de interpretações viriam à tona no II Congresso de Anistia, realizado em Salvador poucos meses depois da publicação da lei.

Heloisa Greco (2003, pp. 309 e 310) chama atenção para o fato de que tal divisão contribuiu para o arrefecimento do movimento nos anos que se seguiram. Paulatinamente, a luta por verdade, memória, justiça e reparação passaria a ser, sobretudo, uma luta dos familiares. E na oposição à ditadura ganharia o primeiro plano o movimento sindical, que destacava as crises econômica e social como os principais prejuízos infligidos pelo governo militar à população brasileira. Como explica Brasílio Sallum (1996), o esgotamento do modelo desenvolvimentista (em boa parte nacionalista) encampado também pelos militares seria um dos principais responsáveis pela derrocada do regime autoritário no começo dos anos 1980.

Ainda de acordo com Heloisa Greco (2003), a anistia aprovada pelo governo em 1979 expressava a lógica interna da Doutrina de Segurança Nacional por meio do estabelecimento da "reciprocidade" dos chamados "crimes conexos" e da exclusão dos guerrilheiros entre seus beneficiários: deste modo, ao invés de uma reciprocidade efetiva, configurava-se uma anistia total para os agentes da repressão, mas uma anistia parcial para os perseguidos políticos. A reciprocidade incompleta da anistia teria como saldo condenável justamente os crimes de sangue cometidos por grupos oposicionistas armados. De certo modo, esta reciprocidade incompleta da anistia de 1979 terminaria por se pautar em razões análogas àquelas mobilizadas para se justificar a conveniência e oportunidade do golpe militar de 1964, que pelo AI-1 prometia o retorno à "normalidade" e à "ordem" por meio da repressão de "grupos subversivos" que ameaçavam a paz e a institucionalidade democrática do país.

É tendo em vista os efeitos da anistia tal como formulada essencialmente por um governo militar que Brasílio Sallum (1996, p. 147) ressalta que a lei 6.683/1979 preparou o terreno para as demais fases da abertura, como o retorno, à cena política, do pluralismo partidário, dos exilados, dos cassados, mas ainda dentro da lógica do controle e da impunidade assegurada aos militares.

De todo modo, uma vez publicada, a Lei de Anistia realmente possibilitou uma abertura significativa. Apesar das controvérsias e dos defeitos apontados pela oposição e por vários movimentos populares, promoveu-se uma reoxigenação no cenário político do 
país com a volta de inúmeros exilados (Cf. Cunha, 2010, p. 32). O Superior Tribunal Militar foi ao trabalho para arquivar processos e libertar alguns presos. Miguel Arraes, Francisco Julião e Gregório Bezerra são alguns dos nomes que obtiveram a declaração de suspensão da punibilidade e dos decretos de prisão preventiva. Mas, ao mesmo tempo em que se anistiavam civis, Petrônio Portela tratou de arquivar as denúncias sobre tortura e desaparecimentos (cometidos por militares) de pessoas ligadas a atividades políticas (Cf. Mezarobba, 2006, p. 51-52).

Ao longo dos anos 1980, a década da redemocratização brasileira, cultivou-se, especialmente a partir dos quadros do último governo militar, a ideia de que a Lei de Anistia atendia à reivindicação popular. Porém, mesmo após sua edição, as prisões e a repressão arbitrárias continuaram. Um exemplo conhecido diz respeito à repressão dos movimentos grevistas dos sindicalistas do ABC paulista na época em que o ex-presidente Lula, então líder sindical, chegou a ser preso, também por razões políticas. Mais uma peculiaridade da anistia brasileira se refere justamente ao fato de ela não ter posto fim à ditadura. Na verdade, foi apenas um dos primeiros passos da chamada "abertura" sob a tutela da ditadura.

O sentido da vitória parcial que representava a anistia aprovada pelo regime militar, embora não viesse a mitigar a expansão de outros benefícios relacionados à própria anistia a partir da Constituição de 1988, criou o pano de fundo político para que a jurisprudência dominante e o discurso oficial dos presidentes (mesmo pós-1988) vissem no projeto aprovado pelo Congresso em 1979 a expressão de uma "reconciliação nacional" aspirada pela sociedade. Como veremos a seguir, este passaria a ser, pelo discurso oficial, o objetivo principal da anistia, mais ressaltado pela fala dos presidentes até mesmo do que a restituição de direitos civis e políticos.

\subsection{2) O discurso sobre o papel da anistia na transição democrática}

Valendo-se da prerrogativa instituída por Emenda Constitucional de 1969, o governo Figueiredo encaminhou ao Congresso seu projeto de anistia, e junto com ele uma mensagem que pretendia justificar seus contornos. ${ }^{8}$ Já na primeira página da mensagem,

\footnotetext{
${ }^{8}$ No Congresso, a mensagem recebeu o número 59/1979. No Planalto, o número 191/1979. Pode ser encontrada em: http://docvirt.com/docreader.net/DocReader.aspx?bib=docbnm\&pagfis=64906\&pesq= (Pasta: Manifestações de Apoio, Categoria Profissional, Pasta 53, p. 13 e seguintes). Última consulta em 04 de fevereiro de 2015. A numeração da mensagem no corpo do texto corresponde à numeração do documento original, não à numeração de busca da mensagem no endereço eletrônico acima referido. Neste endereço
} 
Figueiredo remete à "Revolução" de 1964 dizendo que agora ela se transforma e se "projeta sobre o futuro". O "período de transformações", segundo o ditador, se inaugura com a Emenda Constitucional $n^{\circ} 11 / 1978$, que, entre outras medidas, revogava o AI-5, e teria continuidade com a anistia proposta pelo governo. ${ }^{9} \mathrm{Na}$ mesma página, o texto fala também em aperfeiçoamento das "estruturas sociais para torná-las mais democráticas" e em dar oportunidades a todos os brasileiros que "pretendam oferecer sua contribuição". O momento seria "propício à pacificação", que nasceria de uma "compreensão patriótica". E continua na página seguinte:

"A anistia é um ato unilateral de Poder, mas pressupõe, para cumprir sua destinação política, haja, na divergência que não se desfaz, antes se reafirma pela liberdade, o desarmamento dos espíritos pela convicção da indispensabilidade da coexistência democrática." (Figueiredo, 1979, p. 02).

A mensagem não economiza na insistência da relação entre anistia e pacificação, reunião, entendimento e a construção de um "futuro democrático": "[a anistia] enseja o reencontro, reúne e congrega para a construção do futuro [...]”. Tal desígnio só poderia ser alcançado, contudo, na medida em que seus efeitos atingiriam "extensa área com o pleno esquecimento". Isto porque a sociedade poderia se "traumatizar com o conhecimento de eventos que devem ser sepultados em nome da Paz" (ibid. id.).

É neste sentido que, sem olhar para o passado, mas mirando o futuro, ao lado da anistia, outra medida importante seria, segundo a mensagem, superar o bipartidarismo compulsório, que "não atende mais aos anseios do eleitorado brasileiro, nem dos políticos" (ibid. id.). Ao mesmo tempo, porém, a mensagem tece explicações sobre por que os crimes praticados por "terroristas" não poderiam ser abrangidos pelos efeitos da lei: por não se tratarem, na concepção do presidente Figueiredo, de "crimes políticos". Mesmo assim, garantia, "todos terão seus direitos patrimoniais assegurados perante o Estado" (Figueiredo, 1979, p. 03).

Pouco depois de o projeto para a Lei de Anistia elaborado pelo governo ser divulgado, o Conselho Federal da $\mathrm{OAB}$ encomendou parecer a Sepúlveda Pertence, já à

eletrônico (que reúne uma série de documentos digitalizados sobre a anistia), a mensagem de Figueiredo ao Congresso começa na página 13.

${ }^{9}$ Entretanto, também inserida no contexto de abertura versus controle ou recrudescimento, a EC n ${ }^{\circ} 11 / 1978$ fora considerada pela $\mathrm{OAB}$ já na época como um embuste, uma vez que, ao mesmo tempo em que restituía a institucionalidade do habeas corpus e revogava cassações, entre outras medidas liberalizantes, também conferia ao Executivo vastos poderes para decretar "medidas de emergência", "estado de sítio" ou "estado de emergência", que poderiam ser renovados sem prévia aprovação legislativa por pelo menos 120 dias. 
época jurista respeitável entre seus pares e sobretudo pela oposição. ${ }^{10}$ Em seu parecer, aprovado pela Ordem, Sepúlveda Pertence ajudou a deitar algumas das bases do que viria a ser uma interpretação quase canônica a respeito da Lei de Anistia. Como veremos mais no capítulo a seguir, sua avaliação sobre o projeto de lei seria referência também para ministros do STF que em 2010 votariam contra o pedido de revisão da lei feito pela própria $\mathrm{OAB}$.

Porém, a despeito dos trechos que seriam mais tarde citados a propósito das polêmicas suscitadas pela $\mathrm{OAB}$ cerca de 30 anos mais tarde, o objetivo principal do parecer estava longe de ser atestar a "bilateralidade" da isenção de responsabilidade penal que o projeto de lei sugeria, mas sim atacar a "mesquinharia das discriminações", nas palavras do próprio Sepúlveda Pertence, do projeto, que, ao invés de propor uma anistia verdadeiramente ampla, geral e irrestrita, como demandavam os movimentos sociais, encetava

"odiosa e arbitrária discriminação dirigida exclusivamente aos já condenados por determinados crimes políticos (art. $1^{\circ}, \S 2^{\circ}$ ), ao condicionamento do retorno ou reversão dos servidores públicos à existência de vaga e ao interesse da Administração (art. $3^{\circ}$ ), e à exclusão desse benefício 'quando o afastamento tiver sido motivado por improbidade do servidor' (art. $3^{\circ}, \S 4^{\circ}$ )" (Pertence, 1979, p. 01).

Para respaldar sua crítica ao projeto, como é de costume no meio, Pertence recorreu a figurões da doutrina do Direito pátrio. Pelas breves citações que transcreveu no parecer, o então advogado nos dava uma boa ideia da concepção que tinham os juristas brasileiros a respeito do conceito de anistia. Assim que, para Aníbal Bruno (apud Pertence, 1979, p. 02), “a anistia não se destina propriamente a beneficiar alguém; o que ela faz é apagar o crime e, em consequência, ficam excluídos de punição os que o cometeram" (destaques acrescidos). Rui Barbosa (ibid. id.) também tinha entendimento parecido: "remontando-se ao delito, se lhe elimina o caráter criminoso, suprimindo-se a própria infração". E, por último, não poderia faltar Pontes de Miranda, para quem, “[com a anistia,] olvida-se o ato criminal, com a consequência de se lhe não poderem atribuir efeitos de direito material ou processual. Aconteceu o ato; agora, indo-se ao passado,

\footnotetext{
${ }^{10}$ Pertence fora cassado de sua posição enquanto membro do Ministério Público do Distrito Federal com base no AI-5. A partir de então, passaria a atuar na advocacia ao lado de Victor Nunes Leal, que fora ministro do STF. Anos mais tarde, viria a ser Procurador-Geral da República indicado por Tancredo Neves e ministro do STF indicado por José Sarney, cargo que ocupou até 2006, quando foi aposentado. De certo modo, então, em 2010, cerca de quatro anos depois da aposentadoria de Pertence pelo STF, os ministros da Corte que denegariam o pedido da OAB no bojo da ADPF 153 teriam ainda a conveniência de absorver um parecer de um de seus colegas que fora conselheiro da Ordem à época da tramitação da Lei de Anistia no Congresso.
} 
mesmo onde ele está, acontece juridicamente desaparecer, deixar de ser, não ser" (ibid. id. - destaques acrescidos).

É nestes termos que, embora compreendendo a atuação da luta armada - cujos membros teriam sido levados "à prática de tais fatos [atentados, sequestros etc] sob o clima de terror repressivo do Ato Institucional n ${ }^{\circ} 5$, , de modo que, para Pertence, naqueles tempos seria "impossível qualquer forma de contestação pacífica à ditadura", sendo então equívoca a "qualificação de terroristas" que incidia sobre eles -, o jurista também sustentava que "a mais forte e universal condenação ética da tortura policial não foi óbice à extensão da impunidade legal aos crimes dos que a tornaram rotina, no procedimento da repressão aos adversários do regime" (Pertence, 1979, p. 04).

Além disso, Pertence concordou com a mensagem de encaminhamento do projeto de anistia do governo ao Congresso no que diz respeito ao fato de que a revelação dos porões da ditadura seria antes um inconveniente e poderia traumatizar a sociedade:

“... não há dúvida, como acentua a justificação do projeto, que, se tivessem continuidade, os processos contra os não condenados iriam 'traumatizar a sociedade com o conhecimento de eventos que devem ser sepultados em nome da paz': entre eles, em primeiro lugar, os relativos à institucionalização da tortura aos presos políticos" (Pertence, 1979, p. 05).

$\mathrm{Na}$ página seguinte, reforçou que a anistia da tortura oficial seria feita "em nome do esquecimento do passado para aplainar o caminho do futuro Estado de Direito" (destaques acrescidos). É neste sentido que julgava acertado varrer da história e da memória os episódios de horror praticados no curso da ditadura, e em primeiro lugar justamente os derivados do terrorismo de Estado. Preservar a memória das violações constituiria, em sua opinião, um óbice à formação futura de um Estado de Direito.

Desde o início de seu governo, o general Geisel, antecessor do general Figueiredo, já anunciava a política de distensão que passaria a adotar e que envidaria "sinceros esforços para o gradual, mas seguro, aperfeiçoamento democrático (...) para a criação de um clima salutar de consenso básico" (Geisel, 1975, p. 38). Ao mesmo tempo em que ambos os ditadores repisavam o projeto de "transformar este país numa democracia" (Figueiredo, 1981, p. 175-6), associavam constantemente a democracia a predicados como "consenso básico", "pacificação nacional”, "compreensão patriótica" e congêneres. O termo "conciliação", embora não constasse da Lei de Anistia nem da mensagem de seu encaminhamento ao Congresso, viria a sintetizar esta relação entre democracia e concórdia, união e esquecimento do passado de atrocidades. 
Citando Figueiredo, Christofoletti (2000, p. 63) escreve:

“A conciliação seria 'o olvido de todas as desavenças e pesares', uma trégua, uma política neutra, isenta de paixão, que restabelecesse a normalidade do regime constitucional pelo concurso de todos os que pretendessem que 'acima da causa dos partidos estava a causa do Brasil.,"

É digno de nota, contudo, que o termo passaria a ser usado com maior frequência pelos candidatos da oposição na eleição que elegeria o sucessor de Figueiredo e que então selaria a transição, ainda sob os auspícios do Colégio Eleitoral, para um governo presidido por civis. Tancredo Neves e seu candidato a vice-presidente, José Sarney, passariam a usar o termo com tanta frequência em seus discursos que o desgastariam.

Pelo menos de um ponto de vista discursivo, a questão da conciliação passava a ser tida como central para o processo transitório, e isso tanto para os militares engajados no processo de distensão quanto para a aliança oposicionista que se reuniu em torno de Tancredo e Sarney em 1984. Nos discursos de ambos, aliás, a conciliação torna-se uma categoria hipertrofiada, uma espécie de panaceia a deitar o chão sobre o qual a democracia brasileira poderia geminar. Nas palavras de Tancredo à época da eleição:

"Venho em nome da conciliação. Não podemos, neste fim de século e milênio, quando, crescendo em seu poder, o homem cresce em suas ambições e em suas angústias, permanecer divididos dentro de nossas fronteiras. [...] Dentro dessa ordem de ideias, a conciliação, instruindo o entendimento, deve ser vista como convênio destinado a administrar a transição rumo à nova e duradoura institucionalização do Estado. [...] Quero a conciliação para a defesa da soberania do povo, para a restauração democrática, para o combate à inflação, para que haja trabalho e prosperidade em nossa Pátria. Vamos promover o entendimento entre o povo e o governo, a nação e o Estado. [...] Para a conciliação maior, sem prejuízo dos compromissos de partido e de doutrina, convoco os homens públicos brasileiros, e todos os cidadãos de boa-fé. No serviço da Pátria, há lugar para todos" (Tancredo apud Christofoletti, 2000, p. 97).

No chamado Discurso de Vitória, em novembro de 1984, Tancredo sustentava em sentido parecido:

"Minha formação democrática, alicerçada em uma vida pública em que nunca faltaram o apoio do povo, o voto direto de meus concidadãos e a confiança nas lideranças políticas e sociais, não foi e jamais será marcada por revanchismos ou represálias. [...] Politicamente enfrentaremos com repulsa os radicalismos, que agridem os sentimentos e as tradições nacionais. Repulsa a todos os radicalismos, tanto os de 
esquerda, que nos levam ao fanatismo ideológico, quanto os de direita, carentes de princípios repletos de ambições de poder" (ibid. id., p. 93).

Nestes discursos, ao utilizar termos como "revanchismos", "represálias", "repulsa aos radicalismos", "conciliação" enquanto entendimento e apaziguamento de uma sociedade dividida, Tancredo Neves realizava claramente uma mistura enunciativa entre os desígnios de seu futuro governo e algumas das promessas dos governos militares associadas à distensão. Assim deixava claro que, ao invés de promover uma ruptura ("radical") em relação ao passado, promoveria as reformas e mudanças necessárias para a democratização do país e superação dos obstáculos econômicos, mas sempre mirando o futuro. Isto é, ao mesmo tempo em que o Estado tornar-se-ia democrático, as violações do passado seriam esquecidas em nome da coesão social e da estabilidade política. Qualquer aspiração por justiça, nestes termos, seria a priori associada a "revanchismo" ou "represália".

Com relação a Sarney, ainda em meio às discussões sobre a anistia no fim dos anos 1970, o então líder da Arena (e mais tarde do PDS) no Senado já asseverava:

"Esse assunto não pode ser tema de radicalização nem de julgamento da Revolução sob pena de não haver anistia e de não cumprir os objetivos da conciliação. A discussão não pode ser levada como ponto fundamental, sob pena de comprometer todo o processo de abertura". ${ }^{11}$

Nesta fala, Sarney frisava que a "Revolução" - termo utilizado pelos militares para caracterizar, à sua maneira, o golpe de 1964 - não poderia ser julgada, caso contrário prejudicar-se-iam os "objetivos da conciliação". Neste sentido, então, seria prudente não permitir que os termos do debate suscitado na sociedade ganhassem as discussões no Congresso acerca do projeto do governo Figueiredo.

Alguns anos mais tarde, em pronunciamento que marcaria a dissidência da Frente Liberal em relação ao governista PDS em julho de 1984, Sarney sustentava: “A responsabilidade da Frente Liberal, em relação à unidade do PDS, acabou. Nós estamos preocupados, agora, é com a unidade da nação e com a formação de um governo de conciliação nacional” (Sarney apud Christofoletti, 2000, p. 84). E pouco tempo depois, em documento de agosto de 1984 que criava a Aliança Democrática ${ }^{12}$, o político considerava:

\footnotetext{
${ }^{11}$ Retirado de "Sarney adverte que anistia pode prejudicar a abertura". Jornal do Brasil, Brasília, 22 de fev. 1978. Política e governo, p. 4.

${ }^{12}$ A Aliança Democrática congregava a Frente Liberal, originalmente uma dissidência do governista PDS e liderada por Sarney, ao PMDB, daquele que viria a ser o candidato à presidência pela oposição, Tancredo Neves.
} 
"Só a coesão nacional, em torno de valores comuns e permanentes, pode garantir a soberania do país, assegurar a paz, permitir o progresso econômico e promover a justiça social. Este pacto político propugna a conciliação entre a sociedade e o Estado, entre o povo e o governo. Sem ressentimentos, com os olhos voltados para o futuro, propõe o entendimento de todos os brasileiros" (ibid. id. - destaques acrescidos).

Mesmo décadas depois, a propósito das discussões sobre a revisão da Lei de Anistia suscitadas pela ação do Conselho Federal da OAB junto ao STF, Sarney ainda conservaria opinião muito semelhante:

"Já temos mais de 40 anos de passagem destes episódios todos e, evidentemente, o Brasil adotou a fórmula de ação da anistia, já que não podia anular as violências que foram feitas e assegurar direitos às pessoas que sofreram. Acho que é uma página da história que deve ser virada. Eu participei da negociação da anistia, ela foi negociada entre todas as partes e foi consensual. Anistia é esquecimento, desde o princípio do mundo que ela tem esta concepção". ${ }^{13}$

Uma reflexão acerca do tema em um dos chamados "Textos Políticos" que mantém em seu Blog indica como lhe parece cara até hoje a questão da conciliação para a transição brasileira rumo à democracia. No texto intitulado "20 anos de democracia", Sarney escreve:
"As transformações políticas do Brasil tiveram, ao longo da História, uma marca que as distinguiu dos grandes ciclos mundiais e latino- americanos. Quando surgiram as democracias representativas e o constitucionalismo, o Brasil seguiu o caminho do encontro de forças e da União e evitou o esfacelamento construído nos campos de batalha. $\mathrm{Na}$ volta à democracia, mais uma vez, seguimos caminhos diferentes: optamos por uma transição com conciliação, evitando os traumas e as contas pendentes que ainda marcam outros países.
Tancredo Neves fixara a imagem do conciliador por excelência. Era o homem da negociação e do compromisso, elementos fundamentais da política no Estado democrático."14

Muitos anos mais tarde, já em um contexto de democracia consolidada, o então presidente Fernando Henrique Cardoso, a propósito da Lei 10.559/2002, que criava a Comissão de Anistia, ressaltou que a reparação aos perseguidos pelo regime militar teria um significado que iria além da justiça individual. "Tem um significado mais amplo, mais

\footnotetext{
${ }^{13}$ Veja em MELO, J. "Sarney diz que anistia é esquecimento". Blog de Jamildo, Recife, 18 de jan. 2010. Disponível em: http://blogs.ne10.uol.com.br/jamildo/2010/01/18/sarney-diz-que-anistia-e-esquecimento/. Último acesso: 20 de fevereiro de 2015.

${ }^{14}$ Veja em SARNEY, J. "20 anos de democracia”. Site José Sarney, 10 set. 2011. Disponível em: http://www.josesarney.org/o-escritor/politica/20-anos-de-democracia/. Último acesso: 21 de fevereiro de 2015.
} 
profundo, de reconciliação da sociedade, de reconciliação do povo com as instituições do País." Para ele, "anistia é muito mais do que esquecimento do passado, é mostrar que, daquele momento em diante, se vive vida nova, nos dois sentidos". E acrescentou: "Não pode ser uma anistia que guarde rancor do passado porque o que passou, passou. Tem de se olhar para o futuro, olhar para a frente e temos de fortalecer os valores, que são aqueles que asseguram que aquilo que havia de mau, no passado, não voltará no futuro". ${ }^{15}$

A insistência numa correspondência entre as reivindicações populares de um lado e o projeto da anistia do governo Figueiredo continuaria a mostrar sua força, por exemplo, quando finalmente Luiz Inácio Lula da Silva alcançaria a presidência e quando também já teria mudado de forma significativa sua opinião sobre a Constituição de 1988. Em suas palavras:

\begin{abstract}
"A anistia não foi um ato de benevolência ou grandeza do regime militar, só foi possível pela mobilização crescente da sociedade brasileira. Quer dizer, havia um verdadeiro clamor nacional. Com a anistia, pudemos reincorporar centenas de brasileiros à vida política e pavimentar o caminho da redemocratização, num processo que culminou com uma Constituição que tem garantido avanços extraordinários ao Brasil". ${ }^{16}$
\end{abstract}

Mediante várias declarações como esta na época em que se avizinhava o julgamento do STF sobre a constitucionalidade da Lei de Anistia em 2010, o presidente pressionou indiretamente a Corte - que tinha sete de seus onze ministros nomeados por Lula - para manter a interpretação antiga da lei a fim de que, segundo o próprio Lula, entre outras coisas, a estabilidade política fosse garantida. ${ }^{17} \mathrm{O}$ próprio Partido dos Trabalhadores (PT), uma vez no poder, não desengavetou seus antigos projetos, por exemplo, para abolir a Lei de Segurança Nacional (LSN). ${ }^{18}$

\footnotetext{
${ }^{15}$ Estas declarações de 2002, no final de seu mandato, foram obtidas em "FHC assina anistia a punidos pela ditadura". Paraná Online, Curitiba, 29 ago. 2002. Disponível em: http://www.paranaonline.com.br/canal/vida-e-saude/news/22553/. Último acesso: 20 de fevereiro de 2015.

${ }^{16}$ Cf. em FALCÃO, M. "Lula diz que anistia 'não foi um ato de benevolência"'. Folha Online, São Paulo, 28 ago. 2009. Disponível em: http://www1.folha.uol.com.br/folha/brasil/ult96u613582.shtml. Último acesso: 20 de fevereiro de 2015.

${ }^{17}$ Além disso, Lula posicionou-se pelo patrocínio da defesa do coronel Brihante Ustra, processado pela família Teles pela prática de tortura realizada durante a ditadura, e do coronel Audir Santos Maciel. Assim, ambos seriam defendidos pela Advocacia Geral da União (Cf. Cunha, 2010, p. 37).

${ }^{18}$ Aliás, em 2008, o Ministério Público Federal (MPF) denunciou oito membros do MST com base na LSN.
} 


\section{2) O programa brasileiro de reparações}

Em 1985, o então presidente Sarney enviou uma proposta de Emenda Constitucional para convocar a Assembleia Nacional Constituinte, que se reuniria a partir de 1987. Junto com esta convocação, foi encaminhado ao Congresso um texto que tratava da anistia concedida aos militares cassados desde 1964. Isso teria sido suficiente, segundo Mezarobba (2006, p. 56), para o surgimento de uma corrente no Congresso que passaria a vincular a anistia à Constituinte.

Neste contexto, a Constituinte ampliou os contornos da anistia: seu escopo se estendeu tanto no termo inicial, que passou a ser 1946, quanto no termo final, a promulgação da própria Constituição de 1988; os participantes da Intentona Comunista de 1935 e os integrantes da campanha "O Petróleo é Nosso" também foram anistiados (Cf. Cunha, 2010, p. 34); além disso, possibilitou-se a reparação econômica de um grupo restrito de militares da Aeronáutica, bem como a reintegração de ex-grevistas em muitas empresas privadas e passou a haver a possibilidade de promoção dos servidores públicos aposentados compulsoriamente ou afastados de seus cargos. Entretanto, o artigo $8^{\circ}$ do Ato das Disposições Constitucionais Transitórias (ADCT), o dispositivo constitucional que tratava da anistia, só seria regulamentado por lei em 2002, com a Lei 10.559/2002, que, entre outras coisas, criaria a Comissão de Anistia.

Como foi ressaltado no tópico anterior, pelo menos desde o momento em que o processo de redemocratização foge ao controle dos militares sobre a "abertura lenta e gradual" especialmente a partir do movimento das Diretas Já, a pauta sobre a restituição de direitos civis e políticos - sobretudo dos familiares de mortos e desaparecidos políticos - perdeu centralidade na agenda de demandas populares e das novas organizações da sociedade civil que eram fundadas ou refundadas: em meio a um contexto sócioeconômico bastante precário durante toda a década de 1980 e começo da década de 1990 com o esgotamento do modelo nacional-desenvolvimentista (Cf. Sallum, 1996), altas taxas de inflação e desemprego e pequenas taxas de crescimento, as principais demandas dos movimentos políticos nas ruas foram por direitos sociais e econômicos.

De outra parte, a literatura fala também em certo isolamento dos familiares de mortos e desaparecidos não só pelo número relativamente pequeno de mortes e desaparecimentos em relação às centenas de milhares de outras violações (como cassações, exonerações, prisões ilegais, torturas etc) que atingiram a grande maioria dos 
perseguidos políticos, mas também porque a identificação da maioria dos mortos e desaparecidos com o comunismo ou o socialismo distanciava suas antigas aspirações daquelas dos movimentos políticos que, mesmo a partir de um ponto de vista crítico, passavam a aceitar as regras do jogo democrático - ainda que fosse para transformá-lo, como no caso do sindicalismo ligado ao Partido dos Trabalhadores, que em boa medida conseguiu realizar já praticamente desde sua fundação, no início dos anos 1980, a aproximação ao operariado que, à exceção do PCB até fins da década de 1960, era um objetivo tão claro quanto distante da maioria das organizações de esquerda no país, especialmente daquelas mais diretamente envolvidas com a luta armada (Cf. Ridenti, 1993). ${ }^{19}$

Quando as demandas por justiça de transição passam a ser lenta e fragmentariamente atendidas, a partir de 1995 com a Lei dos Desaparecidos, a disputa política nacional pela Presidência da República começa a ser travada entre dois partidos que, ainda que tivessem entre alguns de seus membros fortes opositores da ditadura militar, não se identificavam de modo essencial com as visões de mundo e estratégias adotadas pelos grupos mais radicais de esquerda antes ligados à luta armada. ${ }^{20}$ Ademais, a conjuntura da geopolítica global com a queda do muro de Berlim e a derrocada da União Soviética e da Cortina de Ferro contribuíram tremendamente para estas transformações das pautas, dos programas e da dinâmica política adotada pelas esquerdas no Brasil. A democracia passava a ser valor universal também para a maior parte da esquerda brasileira $^{21}$, de modo que os ideais que antes inspiravam aqueles que pegaram em armas para combater o regime militar haviam perdido seu momentum e se tornavam, progressivamente, ideais percebidos como do passado.

\subsection{1) A Comissão Especial sobre Mortos e Desaparecidos Políticos}

Muitas emendas propostas pelo MDB ao projeto de lei do governo para a anistia de 1979 aventavam a introdução da possibilidade de pagamento de indenizações aos anistiados, mas, como se viu nos tópicos anteriores, nenhuma destas emendas foi

\footnotetext{
${ }^{19}$ Além de Ridenti (1993), outras obras importantes sobre a luta armada no Brasil são: Aarão Reis Filho (1990) e Jacob Gorender (1987).

${ }^{20}$ Mesmo que, sobretudo no PT, alguns de seus fundadores tenham participado da luta armada, esta identidade passava aos poucos a não mais pautar seus projetos e disputas políticas.

${ }^{21}$ O famoso ensaio de Carlos Nelson Coutinho (1984), além de ser um esforço de aproximar a tradição marxista do conceito de democracia, descrevia de certa forma também um processo de transformação das esquerdas que já estava em andamento.
} 
aprovada. O artigo 11 da Lei de Anistia aprovada, aliás, vedava expressamente o pagamento de reparações econômicas.

Sob a égide da nova ordem democrática, em 1994, a Comissão de Familiares de Mortos e Desaparecidos Políticos e o Grupo Tortura Nunca Mais divulgaram uma carta ao governo Itamar Franco solicitando um compromisso de se reconhecer publicamente a responsabilidade do Estado pela tortura, prisão, morte e desaparecimento de opositores políticos, bem como a criação de uma comissão para investigação e indenização das violações causadas durante a ditadura militar (Cf. Mezarobba, 2007, p. 48). Já no ano seguinte, reforçando as pressões ao governo federal, a Comissão de Familiares e o Grupo Tortura Nunca Mais (RJ e PE), em conjunto com o Instituto de Estudos da Violência do Estado, publicariam o Dossiê dos mortos e desaparecidos politicos a partir de 1964, mais uma documentação produzida com o engajamento de entidades da sociedade civil que dava conta de informações sobre centenas de mortes e desaparecimentos.

Com a pressão política, o governo resolveu elaborar um projeto de lei que abrangeria reparações econômicas e a busca de corpos de desaparecidos políticos. $\mathrm{Na}$ noite em que seria aprovado o projeto de lei do governo, familiares das vítimas fizeram vigília no Congresso. Na oportunidade, uma das integrantes da Comissão de Familiares, Iara Xavier Pereira, comentou: “As nossas reivindicações não têm intuito de revanchismo e vingança. Queremos justiça e fazer justiça é contar a verdadeira história dos desaparecidos, que foram mortos como terroristas e subversivos". ${ }^{22}$ Havia, nitidamente, uma reivindicação por uma redenção da memória pública sobre os perseguidos políticos que morreram ou desapareceram em sua luta contra o regime militar.

A chamada Lei dos Desaparecidos (n. 9.140/1995) foi então aprovada no contexto de implementação do Programa Nacional de Direitos Humanos (PNDH). Com sua publicação, o presidente Fernando Henrique Cardoso fez questão de frisar que não se tratava de revolver os fundamentos da anistia. Da mesma forma que na tramitação da lei de 1979, várias propostas de emenda foram apresentadas ao projeto inicial do governo durante o trâmite do texto no Congresso, mas, seguindo orientação do governo, nenhuma delas foi aprovada. Houve manifestações de insatisfação tanto de militares quanto de familiares. Estes últimos reclamavam do fato de a lei não contemplar a reivindicação de apuração das circunstâncias das mortes e desaparecimentos de perseguidos políticos.

\footnotetext{
${ }^{22}$ Cf. "Familiares não pedem punição". Folha de São Paulo, São Paulo, 29 ago. 1995. Caderno Brasil, p. 8.
} 
Em uma lista elaborada com base no Dossiê de Mortos e Desaparecidos Politicos, a Lei 9.140/1995 reconheceu como mortos de saída 136 desaparecidos. ${ }^{23}$ Também estabeleceu a criação da Comissão Especial sobre Mortos e Desaparecidos Políticos (CEMDP), à qual competiria reconhecer outros desaparecidos (além dos listados na lei), envidar esforços para localizar corpos e processar e julgar pedidos de indenização contemplados por suas disposições. Os familiares tinham 120 dias, a contar da publicação da lei, para protocolarem seus pedidos devidamente instruídos com as provas de que dispusessem para atestar o direito. Também por determinação da lei, as sessões da Comissão eram privadas, com presença em algumas delas, por licença de seu primeiro presidente, o jurista Miguel Reale Júnior, de membros do Grupo Tortura Nunca Mais.

Neste sentido, as famílias eram obrigadas a produzir a documentação para instruir seu pedido, mas sem dispor de acesso a arquivos do SNI (Serviço Nacional de Informações), da Polícia Federal e das Forças Armadas. A lei também não previa ressarcimento de danos provocados a pessoas que sofreram ferimentos em manifestações, vítimas de atentados ou mortos em outros países. Por força da Lei 10.536, a partir de 2002, a abrangência dos casos passíveis de reconhecimento pela Comissão se estendeu até a promulgação da Constituição de 1988. Em 2004, outro dispositivo legal estendeu os benefícios da lei também a familiares de vítimas mortas em confronto com a polícia em locais abertos e públicos, bem como casos de suicídios decorrentes da pressão psicológica desencadeada pela perseguição política (Cf. CEMDP, 2007).

De acordo com o artigo 11 da Lei 9.140/1995, os critérios de reparação para familiares de mortos e desaparecidos políticos consistem no pagamento de valor único equivalente a três mil reais (corrigidos monetariamente ao longo dos anos) multiplicado pelo número de anos correspondentes à expectativa de sobrevivência do desaparecido, levando-se em conta a idade à época do desaparecimento, além de outros critérios constantes de um anexo da lei.

A CEMDP era composta em sua maioria por advogados e também contava sempre com pelo menos um membro do Ministério Público e um militar. João Grandino Rodas, que mais tarde se tornaria reitor da USP, também foi integrante da Comissão por muitos anos, sendo famoso por denegar, em votos vencidos em conjunto com o integrante militar e eventualmente com o membro do Ministério Público, indenizações de personalidades notórias da luta contra a ditadura, como Carlos Lamarca e Carlos Marighella. Por pressão

\footnotetext{
${ }^{23}$ Entretanto, a Comissão chegaria à conclusão, muitos anos mais tarde, de que uma das pessoas arroladas na lista teria, na verdade, falecido em decorrência de causas naturais (Cf. CEMDP, 2007).
} 
dos familiares, entre 2003 e 2004, alguns membros da Comissão foram trocados, dentre eles o próprio Rodas.

Em 11 anos de funcionamento, 475 casos foram apreciados, dos quais 136 já estavam automaticamente reconhecidos pela própria lei em um de seus anexos. O valor mínimo pago a título de indenização foi de $\mathrm{R} \$ 100$ mil e o máximo, de $\mathrm{R} \$ 152$ mil. $\mathrm{O}$ valor médio pago a título de indenização girou em torno dos R\# 120 mil. Aproximadamente 40 milhões de reais foram pagos a familiares de mortos e desaparecidos políticos (Cf. CEMDP, 2007).

A CEMDP também realizou algumas expedições à região do Araguaia para a localização de corpos. Muitas vezes sem contar com o apoio do Exército ou da Polícia Federal, algumas destas expedições tiveram de se valer de mapeamento da região realizado pela Comissão de Familiares em suas próprias expedições ao local, realizadas desde a década de 1980 (Cf. Teles, 2005). Já outras expedições puderam contar com o apoio do Exército e até do Ministério Público Federal.

Um saldo positivo, por outro lado, foram os depoimentos colhidos junto a moradores da região, que relataram as atrocidades cometidas pelos militares inclusive contra membros das comunidades que não haviam aderido à guerrilha. Em 2007, com estes e outros relatos, foi publicado o livro-documento Direito à memória e à verdade, com base nos resultados dos trabalhos realizados pela CEMDP. Outro saldo positivo diz respeito ao fato de que a chamada Lei dos Desaparecidos, ao estabelecer o princípio da continuidade do Estado, firmou o reconhecimento da responsabilidade estatal pelas violações cometidas durante o regime político militar.

Mesmo assim, dos 16 pedidos de indenização interpostos por familiares de camponeses mortos na guerrilha do Araguaia, apenas um foi reconhecido pela Comissão. Além disso, um dos relatórios da Comissão Interministerial para busca e identificação das ossadas no Araguaia deixou claro "não ser objeto da Comissão fazer uso das informações para a revisão da chamada Lei de Anistia". ${ }^{24}$ É neste sentido que Janaína de Almeida Teles (2005, p. 08) destaca que a Lei dos Desaparecidos ficou limitada pelos parâmetros da anistia e de sua interpretação enquanto recíproca. Seu artigo $2^{\circ}$, por exemplo, determina que a aplicação das disposições da lei e seus efeitos devem se orientar "pelo princípio de reconciliação e de pacificação nacional".

\footnotetext{
${ }^{24}$ Cf. Comissão Interministerial para Identificação de Desaparecidos da Guerrilha do Araguaia (2007).
} 
Com relação ao livro Direito à memória e à verdade, de autoria da CEMDP (2007), trata-se da principal publicação feita em nome do Estado brasileiro, antes do relatório final da Comissão da Verdade, dando conta do eixo "verdade e memória". Na "Apresentação" ao texto, o então ministro da Secretaria Especial dos Direitos Humanos, Paulo Vannuchi, e o Presidente da CEMDP, Marco Antônio Rodrigues Barbosa, revelam que entendem o documento como um importante passo do país rumo a novo status no cenário internacional dos direitos humanos. Em referência àquela que passaria a ser a próxima fase dos trabalhos da Comissão, ambos também destacam o direito milenar de os familiares sepultarem seus entes queridos. E por fim atestam ainda a insuperável relação dos trabalhos da Comissão com a Lei de Anistia e alguns de seus aspectos centrais tratados por governantes, operadores do direito e agentes de políticas públicas que vieram antes deles:

"O lançamento deste livro na data que marca 28 anos da publicação da Lei de Anistia, em 1979, sinaliza a busca de concórdia, o sentimento de reconciliação e os objetivos humanitários que moveram os 11 anos de trabalho da Comissão Especial” (Vannuchi e Barbosa, 2007, p. 09 destaques acrescidos ao original).

A "reconciliação como concórdia", pode-se dizer, era expressa até mesmo na composição da Comissão, que contava com uma espécie de "equilíbrio entre as partes": com um presidente indicado pelo governo, um membro da Comissão (mais tarde Secretaria) de Direitos Humanos, um representante da sociedade civil, um representante dos familiares, um representante das Forças Armadas, um do Ministério Público Federal e um do Ministério das Relações Exteriores.

Ao final de 2006, a Comissão terminou a avaliação de praticamente todos os pedidos, passando a concentrar-se, a partir do ano seguinte, em uma nova fase de seus trabalhos: a constituição de um banco de DNA dos familiares para a comparação e identificação de desaparecidos cujos restos mortais tenham sido encontrados. Neste novo período também, o objetivo passou a ser sistematizar as informações sobre as várias valas clandestinas espalhadas pelo país. A Comissão então assume o papel de se fazer juiz da história "ao fazer o resgate da memória e da verdade" (CEMDP, 2007, p. 18).

Neste ponto, apesar de repisar a questão da concórdia, guarda importante diferença em relação ao entendimento anteriormente disseminado segundo o qual, para se seguir adiante na construção da democracia, seria preciso esquecer o passado de violações. $\mathrm{Na}$ perspectiva agora apresentada, "Só conhecendo profundamente os porões e as atrocidades 
daquele lamentável período de nossa vida republicana, o País saberá construir instrumentos eficazes para garantir que semelhantes violações dos Direitos Humanos não se repitam nunca mais" (CEMDP, 2007, p. 18). A ideia central agora é conhecer para não repetir.

O livro não realiza simplesmente um relato das violações, mas traz um balanço histórico do golpe e da ditadura civil-militar no contexto da Doutrina da Segurança Nacional, comum aos regimes autoritários do Cone Sul na época e que no Brasil tinha na Escola Superior de Guerra o centro de sua irradiação ideológica. Além do contexto político e ideológico que possibilitou a instauração da ditadura no país, o texto também tenta dar conta em linhas gerais da estrutura do aparato repressivo que se instalou desde o Conselho Nacional de Segurança, passando pela Operação Bandeirantes (OBAN), o Destacamento de Operações de Informações/Centro de Operações de Defesa Interna (DOI-CODI), e incluindo também os Departamentos de Ordem Política e Social (DOPS), a Polícia Federal e os Centros de Informações da Aeronáutica e da Marinha. Em seguida, o livro dá destaque também para a resistência da oposição institucional que girava em torno do Movimento Democrático Brasileiro (MDB) e também para a luta armada. Nesta passagem, há breve referência aos crimes praticados pelas guerrilhas urbanas e rurais para a viabilização de sua campanha e no curso dos combates contra as forças de segurança.

Em detalhes, o livro narra a estratégia adotada pela repressão para aniquilar primeiro as guerrilhas urbanas e rurais, para depois, já no início do período conhecido como da "distensão" ou transição controlada, concentrar-se nos dirigentes remanescentes do Partido Comunista do Brasil (PCB), que haviam sido até então parcialmente poupados das mortes e desaparecimentos (mas de modo algum de prisões ilegais e torturas) em função de não terem apoiado a luta armada. ${ }^{25}$

Mesmo depois de aniquilados os movimentos guerrilheiros e iniciada a distensão, como reconhece o livro, as mortes e desaparecimentos continuaram, assim como muitas das notas oficiais dando conta de suicídios, a maioria dos quais desmentida anos mais tarde. O texto também relata sucintamente as idas e vindas do processo de distensão, o qual, embora tenha contado com medidas como a extinção do Ato Institucional n. 5,

\footnotetext{
${ }^{25}$ Os dirigentes remanescentes do PCB são os que não haviam trocado o partido por uma ou mais das inúmeras dissidências que começaram a surgir justamente a partir do golpe e em função de uma autocrítica de parte dos integrantes do partido no sentido de que a aliança com a burguesia nacional e a estratégia de uma revolução democrática "dentro das regras do jogo" para preparar o caminho ao socialismo se mostravam equivocadas (Cf., dentre outros, Ridenti, 1993). Uma importante dissidência anterior ao golpe, entretanto, formou, já em 1962, o Partido Comunista do Brasil (PCdoB), com sigla diferente, mas recuperando o nome original do PCB, que a partir de 1960 passara a se chamar Partido Comunista Brasileiro.
} 
também viu a edição, em 1976, da Lei Falcão e, um ano depois, do Pacote de Abril, que introduziu a figura do senador biônico, entre outras medidas visando a conter os avanços do MDB sobretudo a partir das eleições de 1974. O processo real de redemocratização, na interpretação apresentada, começa efetivamente com a Lei de Anistia e com o retorno do pluripartidarismo em 1979, quando, todavia, ainda eram frequentes as torturas, prisões ilegais, atentados a bomba, mesmo mortes e desaparecimentos e outras operações repressivas. No final do livro é apresentado um breve histórico de cada uma das várias organizações (a maioria, mas nem todas de esquerda, sendo estas últimas de alguma forma originárias de dissidências do PCB) envolvidas na luta armada. Neste ponto, o texto traça mais uma vez uma narrativa bastante sóbria e equilibrada sobre a formação destas organizações, sem julgar eventuais erros históricos que possam ter cometido nem, por outro lado, fazer uma simples apologia de seu papel, muitas vezes distorcido, de mártires da democracia.

Afinal, a partir de meados dos anos 1960, boa parte destas organizações (sobretudo as várias dissidências com origem no $\mathrm{PCB}$ ) passou a avaliar que o compromisso do PCB com as elites burguesas na democracia teria antes tornado o objetivo do socialismo ou do comunismo mais distante, e não mais próximo, de modo que não caberia mais investir no aprofundamento da democracia (que se mostrara demasiado frágil) para esgarçar as contradições do modo de produção capitalista e então catalisar a união dos trabalhadores em torno do projeto de revolução socialista. De modo diverso da via soviética e cada vez mais em sintonia com as experiências revolucionárias chinesa e cubana, boa parte destas dissidências passou a encarar a necessidade de se realizar o processo revolucionário sem um prévio aprofundamento da democracia e do capitalismo e a partir de um movimento guerrilheiro que teria sobretudo no campo a sua origem (Cf. Ridenti, 1993).

Outra operação muito difícil de se realizar - mas que o livro da CEMDP não pôde fazer em parte por causa de seu escopo - seria procurar entender e eventualmente avaliar a atuação destes grupos a partir de seu próprio contexto e realidade histórica. Isto é, a partir de uma episteme que não tinha no conceito de democracia um horizonte normativo universal e praticamente consensual, como acontece hoje, pelo menos nos termos da teoria política. O sociólogo Marcelo Ridenti (1993), apesar de reconhecer-se como pertencente a uma geração já posterior à da luta armada, consegue fazê-lo ao realizar a difícil tarefa de reambientar o leitor naquela outra episteme, muito diferente desta em que vivemos pósqueda do muro de Berlim e na qual ocasionalmente se adota, de modo um tanto anacrônico, a democracia liberal como critério de avaliação de decisões tomadas em um 
passado que, embora não tão distante, respirava, além da democracia liberal, outras possibilidades de devir histórico que poderiam dar conteúdo ao objetivo da emancipação humana. ${ }^{26}$

Aliás, a própria caracterização de uma "resistência democrática" de muitos destes movimentos da luta armada por documentos e declarações oficiais do governo brasileiro e das próprias comissões de reparação pode ser resultado de uma dificuldade em se reconhecer esta outra episteme e em atribuir anacronicamente um horizonte normativo que certamente não fazia parte da grande maioria daquelas organizações. Ao mesmo tempo, é acertado constatar, como fazem estes documentos, que o fenômeno da luta armada formou-se fundamentalmente apenas depois do golpe militar e como uma reação à ditadura que se instaurava. Neste sentido, embora não necessariamente "democrática" (pelo menos na maioria dos casos), de fato a luta armada constituiu-se como uma "resistência" aos mandos e desmandos da ditadura civil-militar. ${ }^{27}$

O outro livro promovido pela CEMDP cuja publicação tem pelo menos o mesmo nível de importância de Direito à verdade e à memória é Retrato da repressão política no campo (Carneiro e Cioccari, 2011), que traz uma narrativa pormenorizada não só da perseguição política na zona rural no Brasil entre 1962 e 1985, mas também da resistência e da luta fundiária que se desenrolaram neste período. ${ }^{28}$ Depois da publicação de Direito à verdade e à memória, o trabalho da CEMDP como uma comissão de reparação econômica ainda continuou, especialmente para avaliar pedidos de familiares de camponeses mortos ou desaparecidos. Entretanto, como a documentação das perseguições sofridas se mostrou ainda mais escassa no campo, para a elaboração do livro foi preciso montar uma verdadeira equipe de pesquisa e parcerias com universidades e outros pesquisadores com acúmulo na área. Mediante os recursos do governo foi possível ao grupo articular rapidamente organizações sindicais do campo e centros de pesquisa da vida do trabalhador rural para mapear e levantar depoimentos, literatura e documentos a respeito da repressão e da resistência.

\footnotetext{
${ }^{26}$ Esta ambientação Ridenti faz não só no já citado O fantasma da revolução brasileira, mas também em outras obras, como Em busca do povo brasileiro (2000) e sobretudo Brasilidade revolucionária (2010), que têm, entre outros méritos, o de situar o leitor num universo (do pós-Segunda Guerra no Brasil) em que uma visão de mundo "de esquerda" ou "revolucionária" (apesar dos vários sentidos que estas palavras podem assumir) dominava o ambiente artístico e intelectual, embora, simultaneamente, o PCB tenha sobrevivido na (semi-)clandestinidade na maior parte do tempo, mesmo durante o período democrático de 1945 a 1964.

${ }^{27}$ Uma importante exceção à constituição de guerrilhas pós-golpe de 1964 são as Ligas Camponesas, que em função da dinâmica própria da disputa fundiária, já se armavam pelo menos desde o início dos anos 1960 no campo (Cf. Bastos, 1984).

${ }^{28}$ Embora publicado sob a rubrica do Ministério do Desenvolvimento Agrário, a encomenda da obra foi feita sob os auspícios e direção da CEMDP.
} 
Este processo de elaboração trouxe pelo menos dois importantes diferenciais em relação a Direito à memória e à verdade: primeiro, que Retrato da repressão política no campo não foi baseado fundamentalmente em processos administrativos de reparação econômica, e segundo, um corolário do primeiro diferencial, este livro traz um retrato menos passivo daqueles que de alguma forma sofreram perseguições políticas no período. Se Direito à memória e à verdade focou-se principalmente nos eventos de perseguição, desaparecimento ou morte, Retrato da repressão política no campo narra também - e com destaque - como os trabalhadores rurais lutaram por seus direitos ou por novos direitos, dando assim uma dimensão da experiência daqueles que resistiram à repressão no campo não só na sua condição de vítimas da perseguição política, mas também na sua condição de sujeitos que tomaram suas escolhas, organizaram-se e procuraram lutar por elas.

$\mathrm{Na}$ apresentação à primeira edição do livro, Guilherme Cassel, então ministro do Desenvolvimento Agrário, e Paulo Vannuchi, então ministro da Secretaria de Direitos Humanos, mais uma vez destacaram a relação entre memória e democracia, que não era aventada por órgãos do governo brasileiro antes de 2007:

"Jogar luzes sobre esse período de sombras e de arbítrio e abrir todas as informações sobre violações de Direitos Humanos ocorridas durante a ditadura militar é um imperativo da reconstrução histórica e, ao mesmo tempo, um imperativo da própria democracia brasileira" (Cassel e Vannuchi, 2011, p. 13).

Organizado por Ana Carneiro e Marta Cioccari, pesquisadoras do programa de pós-graduação em Antropologia Social do Museu Nacional, o projeto de elaboração do livro contou com a experiência de pesquisadores, documentos e literatura disponibilizados pelo Núcleo de Antropologia da Política do Museu Nacional, que há anos desenvolvia um Projeto Temático intitulado Memória Camponesa sob a coordenação de Moacir Palmeira, com várias universidades envolvidas. Também contaram com contribuições significativas do Núcleo de Pesquisa, Documentação e Memória do Departamento de História da Universidade Federal de Minas Gerais, coordenado pela professora Heloisa Starling. Os pesquisadores engajados no projeto tiveram acesso a uma série de arquivos em todo o país. Em boa parte, Retrato da repressão política no campo leva adiante uma tarefa de sistematização de pesquisas feitas por outros autores e centros de pesquisa, mas desta vez atribuindo ao resultado um caráter, se não oficial, pelo menos oficioso, e portanto de reconhecimento do Estado acerca de seu conteúdo. Além da sistematização do grande volume de pesquisa que já existia a respeito, os pesquisadores engajados na elaboração do 
livro também colheram depoimentos de primeira mão de vários camponeses de algum modo associados às repressões políticas do passado.

Em sua avaliação sobre a repressão no campo no período estudado, as pesquisadoras reconhecem que ela tem início bem antes do golpe militar no país e que de certa forma ela permeia toda a história brasileira. Entretanto, segundo as autoras, a instauração de mais uma ditadura teria exacerbado a ligação entre as oligarquias rurais e a máquina burocrática. Desde os primeiros dias que se sucederam ao golpe, diversos membros das Ligas Camponesas e sindicalistas rurais sofreram inúmeros ataques em que foram presos, torturados e/ou assassinados, na maioria dos casos por milícias privadas contratadas por latifundiários, mas sempre com a complacência do poder público (Cf. Carneiro e Cioccari, 2011, p. 27-28). ${ }^{29} \mathrm{O}$ livro, de mais de 400 páginas, é dividido em quatro capítulos que procuram retratar a repressão e a resistência de forma detalhada em cada região do país. Ancoradas em ampla pesquisa prévia, foi possível às pesquisadoras montar uma narrativa consideravelmente mais abrangente do que a construída no livro Direito à memória e à verdade.

\subsection{2) A Comissão Nacional de Anistia}

O artigo $8^{\circ}$ do Ato das Disposições Constitucionais Transitórias (ADCT) prevê cinco direitos aos anistiados políticos: a declaração de anistiado, a contagem do tempo em que foi obrigado a afastar-se de suas atividades profissionais para fins previdenciários, a reparação econômica, a conclusão de curso eventualmente interrompido e a reintegração de servidores públicos ou funcionários da iniciativa privada empregados em concessionárias ou permissionárias de serviços públicos. Entretanto, este dispositivo carecia de regulamentação infraconstitucional para ser aplicado até 2001, quando foi editada a Medida Provisória 2.151, que criou a Comissão Nacional de Anistia no âmbito do Ministério da Justiça. A MP foi mais tarde transformada na Lei 10.559/2002.

Esta lei de 2002 tinha o condão de abarcar todos os demais casos de reparação por perseguição política que não fossem morte ou desaparecimento. A fim de homogeneizar as reparações, a lei também estabeleceu que os processos de anistia, concluídos ou em

29 Muito diferente do que em geral acontece quando a situação é inversa, isto é, quando é o camponês que, justificada ou injustificadamente, realiza um ataque violento a latifundiários, familiares, subordinados ou milicianos. Nestes casos, dizem as autoras (Carneiro e Cioccari, 2011, p. 27), as punições, legais ou ilegais, são quase que invariavelmente "exemplares". 
andamento, com tramitação em órgãos da Administração Pública, fossem remetidos para a Comissão de Anistia, para que fossem ali redefinidos.

O primeiro presidente da Comissão de Anistia foi nomeado por Lula em 2003. Tratava-se do advogado e ex-presidente do Conselho Federal da OAB, Marcello Levanère Machado. Em entrevista cedida a Glenda Mezarobba (2007, p. 148), Levanère disse que os militares resolveram não se opor aos trabalhos da Comissão na medida em que percebiam que não se tratava de "deboche" ou "revanchismo"; "não há esse espírito", comentou. Era, segundo ele, apenas um reconhecimento de que o Estado devia àquelas pessoas. "Nós estamos reparando os excessos que o Estado cometeu, porque o Estado prendeu, porque o Estado torturou", continuou em outra passagem (grifos meus).

A indenização estabelecida pela Lei 10.559/2002 prevê prestação mensal em valor correspondente ao que a pessoa receberia em sua atividade laboral, caso não tivesse sofrido a perseguição política. Os valores são calculados conforme a expectativa normal de promoção em cargos púbicos e privados, e neste último caso, estipula-se o valor de mercado da função que o anistiado poderia ter ocupado. Segundo Torelly (2012, p. 234), que fora coordenador de projetos da Comissão de Anistia, o critério laboral para o cálculo das reparações justificar-se-ia em função das modalidades de perseguição política mais adotadas pelo regime militar: cassações de mandatos políticos, exonerações de servidores públicos e demissões de trabalhadores da iniciativa privada.

De todo modo, mais uma vez, a Lei de Anistia forneceu as bases também para o programa de reparação previsto nesta lei, sobretudo no que diz respeito à perda do emprego como principal critério a pautar o cálculo das indenizações. Na lei de 1979, os artigos $2^{\circ}$ e $3^{\circ}$ delineavam os contornos do processo de readmissão de servidores civis e militares da Administração Pública, ressaltando que, em qualquer caso, a concessão da readmissão dependeria da existência de vaga para o requerente. Já trabalhadores civis ligados a sindicatos e estudantes tinham sua anistia regulada pelo artigo $9^{\circ}$ da Lei 6.683/1979, sem qualquer menção a uma compensação pelos danos sofridos.

Entretanto, a Lei 10.559/2002, também prevê pagamento de indenização para aqueles que não experimentaram afastamento de atividade laboral em função da perseguição política (ou porque conseguiram manter seus empregos ou porque não desempenhavam atividade laboral, como boa parte dos estudantes). Nestes casos, a indenização é paga em parcela única, de até 30 salários mínimos por ano de perseguição política, sendo que o teto da indenização é estipulado em R\$ 100 mil (atualizados monetariamente). Com isso, o teto do pagamento de indenização em prestação única a 
anistiados políticos que sofreram qualquer tipo de perseguição política exceto morte e desaparecimento forçado coincide com o piso da indenização paga a familiares de mortos e desaparecidos políticos.

Em um avanço em relação à Lei dos Desaparecidos, a lei de 2002 prevê que a própria Comissão deve levar a efeito as diligências para a instrução dos pedidos. Também não determina prazo limite para interposição destes nem a renúncia de eventual ação de indenização promovida no Judiciário pelo anistiado contra o Poder Público.

Depois de algum tempo de realização dos trabalhos da Comissão de Anistia, alguns problemas da legislação relativos aos critérios das indenizações começaram a ser questionados, pela mídia, sobretudo em relação aos (altos) valores pagos em muitos casos, e pela literatura, em função de eventuais incongruências entre os critérios adotados pela Lei dos Desaparecidos e os adotados pela Lei 10.559/2002, e entre os dois critérios de indenização (prestações mensais e prestação única) desta lei. Torelly (2012) sistematiza bem o conjunto destas críticas em três possíveis incongruências.

A primeira delas seria entre os critérios da Lei 10.559/2002 e os critérios da Lei 9.140/1995. Para Torelly (2012, p. 253), não há assimetria entre a compensação em parcela única paga por meio da Lei dos Desaparecidos e a compensação em parcela única paga por meio da Lei 10.559/2002, uma vez que o piso do pagamento de uma (relativa ao evento morte ou desaparecimento) coincide com o teto para pagamento da outra (demais tipos de perseguição política).

Mas é importante frisar que, em relação às prestações mensais previstas pela Lei 10.559/2002, estas podem se acumular com a reabilitação (readmissão em cargo ou emprego), além de serem pagas retroativamente. ${ }^{30}$ Também é computado, retroativamente, o tempo de serviço. Com isso, além das prestações mensais vindouras, aqueles que têm o direito de reparação econômica mensal reconhecido também têm direito a um pagamento único relativo às prestações retroativas (obedecendo-se a prescrição quinquenal). Em boa parte dos casos, esta remuneração das parcelas retroativas pode chegar a centenas de milhares de reais, em muitos casos um valor bastante superior ao pago a familiares de mortos e desaparecidos políticos.

\footnotetext{
${ }^{30}$ Há, entretanto, a prescrição quinquenal para as dívidas da União, o que significa, na prática, que as parcelas retroativas devidas ao anistiado que tem o direito de indenização reconhecido são as que se acumularam num período de cinco anos, contados retroativamente da data de protocolo de seu requerimento. Isto é, se o requerente protocolou seu pedido em 2010, uma vez reconhecido seu direito à indenização, fará jus ao pagamento de parcelas "em atraso" desde 2005, além das parcelas posteriores ao protocolo do pedido.
} 
Para Torelly, entretanto, a superação desta aparente assimetria está na possibilidade de familiares de mortos e desaparecidos políticos requererem também as reparações econômicas previstas pela Lei 10.559/2002, além da compensação prevista na Lei dos Desaparecidos. ${ }^{31}$ A legislação não impede que familiares de mortos e desaparecidos políticos pleiteiem uma dupla indenização, isto é, uma junto à CEMDP e outra junto à Comissão de Anistia: a indenização pela morte ou desaparecimento não impede o pagamento de indenização pelas outras perseguições que o falecido ou desaparecido sofrera antes. Torelly argumenta também que a maioria dos presos e torturados também acabaram por perder postos de trabalho, de modo que o cálculo da situação laboral aproveitaria à maioria daqueles que sofreram o suplício capital.

Contudo, o fato de, "na maioria dos casos", não haver potencial assimetria não resolve o problema de princípio contido na lei, que pode e tem ensejado grandes diferenças de indenização entre familiares de alguns mortos e desaparecidos políticos e outros perseguidos. Imagine-se a situação não rara de um morto ou desaparecido pela repressão e que era estudante à época da ditadura. Sua família teria, em tese, direito a pagamento de prestação única (porque não pautada em perda de emprego) pela Lei 10.559/2002 (em decorrência, por exemplo, de torturas ou prisões ilegais que tenha sofrido) e de outra prestação única pela Lei 9.140/1995 (em decorrência da morte ou desaparecimento). O máximo que os familiares poderiam receber, somadas as duas prestações únicas, seria algo em torno dos R\$ 250 mil acrescidos de correção monetária (R\$ 100 mil do teto da prestação única da Lei 10.559/2002 e cerca de R\$ 150 mil para o valor máximo pago pela Lei dos Desaparecidos), mesmo tendo este estudante sido preso e torturado durante anos antes de ser morto ou desaparecido. ${ }^{32}$ Por outro lado, o jornalista e escritor Carlos Heitor Cony, por exemplo, quem a Comissão de Anistia considerou poder ter se tornado editor-chefe de jornal não fosse a perseguição política que sofreu durante a ditadura, recebeu, apenas de parcelas retroativas, o equivalente a R $\$ 1,41$ milhão (Cf. Comissão Nacional de Anistia, 2010). ${ }^{33}$

A diferença não só pode, mas muitas vezes acontece de ser brutal, e não se pode negar que, de certa forma, o conjunto das legislações do programa brasileiro de reparações, ao adotar o critério laboral como o principal para atribuir as indenizações,

\footnotetext{
${ }^{31}$ Paulo Abrão et al. (2009) também rebatem as críticas ao que parte da literatura considera como incongruências dos critérios de indenização.

${ }^{32}$ Entretanto, é bem provável que na maioria dos casos como este a soma das indenizações redundasse em valor consideravelmente menor.

${ }^{33}$ As parcelas mensais que o jornalista recebe superam os R\$ 20 mil.
} 
pode encetar distorções marcantes em desfavor dos perseguidos políticos que possuíam algum emprego de menor remuneração ou que não possuíam emprego à época da perseguição, mas que nem por isso sofreram menos e menores suplícios. Basta lembrar que a maioria dos integrantes da luta armada, praticamente dizimada pela repressão, era composta por estudantes (Cf. Ridenti, 1993), para se entender que a preponderância em termos financeiros do critério laboral para a concessão de indenizações não foi uma escolha acertada.

A segunda assimetria diz respeito ao fato de que duas pessoas que sofreram perseguições muito parecidas podem receber compensações bastante distintas. Esta incongruência é reconhecida como insuperável por Torelly (2012, p. 255-6), mas a razão é basicamente a mesma do primeiro caso: o fato de o critério ser pautado fundamentalmente nas relações de trabalho, não nos sofrimentos efetivamente infligidos. A diferença é que aqui a assimetria parece ser mais evidente pelo fato de se falar hipoteticamente em pessoas que teriam sofrido perseguições parecidas, mas que, em função de desempenharem atividades laborais diferentes (ou uma delas não trabalhar) na época destas perseguições, fazem jus a compensações distintas. De certo modo, isto produz uma espécie de diferenciação social ou corporativa das indenizações em detrimento de uma diferenciação em função do dano experimentado. ${ }^{34}$

Uma terceira assimetria que pode ocorrer diz respeito a diferenças de indenização entre anistiados pela lei 10.559/2002 e detentores de aposentadorias excepcionais (arbitradas, antes da criação da lei em 2001, pelos próprios órgãos públicos a que estavam vinculados os perseguidos). Os critérios para estas aposentadorias excepcionais variavam muito de órgão para órgão e, por muitas vezes, os valores por eles arbitrados superavam em muito o que poderia ser estipulado pela Comissão de Anistia, gerando assimetrias entre cidadãos com situações análogas. Por isso a legislação determinou que estes beneficiários também passassem a ser remunerados de acordo com os novos critérios determinados pela Comissão de Anistia.

$\mathrm{Na}$ mídia foram publicadas ao longo de anos muitas matérias sobre as famosas “indenizações milionárias", e mesmo entre os anistiados houve sentimentos de injustiça. Ministros ligados ao governo e até decisões na Justiça reprovaram o que consideravam como excessos nas indenizações (Cf. Mezarobba, 2007). A partir disso, o governo Lula,

\footnotetext{
${ }^{34}$ Torelly também relata que há possibilidade mais concreta de reabilitação no setor público do que no privado. Muitos dos anistiados que exerciam funções públicas puderam usufruir de benefícios da Administração Pública, como assistência médica e odontológica e financiamento habitacional. Para a iniciativa privada não houve previsão de mecanismos de reabilitação na lei.
} 
em seu primeiro mandato, resolveu realizar uma série de auditorias fiscais na Comissão, as quais encontraram várias irregularidades relativas a incongruências das concessões frente à legislação e a decisões anteriores da própria Comissão, a qual pecava, neste sentido, também pela falta de coerência.

O governo Lula, visando tentar conciliar as metas de austeridade fiscal com o pagamento das indenizações, estipulou uma dotação orçamentária para os trabalhos e indenizações da Comissão. A maioria dos pedidos passou a ser denegada, segundo entendimento do então ministro da Justiça, Márcio Thomaz Bastos, porque havia muitos intermediários de má fé que convenciam pessoas a entrar com pedidos de indenização, mesmo em hipóteses que não se enquadravam nos benefícios da lei (Cf. Mezarobba, 2007, p. 146). A partir de 2007, a Comissão de Anistia também passou a se valer de pesquisas de mercado (não informações genéricas de antigos empregadores ou organizações sindicais) para fixar a remuneração-base do anistiado, e assim padronizar o arbitramento de indenizações. Pesquisas de mercado também passaram a ser utilizadas em relação a trabalhadores do setor público, para minimizar as assimetrias em relação aos trabalhadores do setor privado.

Outro problema que passou a se tornar crônico dizia respeito ao fato de que a dotação orçamentária da Comissão não considerava o pagamento das parcelas retroativas das indenizações. Tendo em vista este problema, que além de insatisfação, motivou uma série de ações na Justiça contra a União, o governo federal editou em 2006 uma Medida Provisória que passou a regulamentar o pagamento dos atrasados: o anistiado teria de assinar um "termo de adesão" expressando sua anuência ao valor estipulado pela Comissão e sua forma de pagamento, além de comprometer-se a não questionar judicialmente o valor indenizado. Com algumas alterações, esta Medida Provisória também foi transformada em lei.

Apesar das incongruências que apresenta, o programa brasileiro de reparações se mostra de fato bastante abrangente, cobrindo praticamente todo tipo de reparação segundo a classificação de Pablo de Greiff (2010): desde a restituição, que é uma forma de restabelecer o status quo ante, no caso da legislação brasileira, pela reintegração do anistiado ao emprego; passando pela compensação, que constitui em geral em indenização financeira pelos danos materiais e morais experimentados; até se chegar à reabilitação, que diz respeito a um suporte material ou psicológico ao perseguido. Neste último quesito, a Comissão de Anistia recentemente implementou o projeto Clínicas do Testemunho, que consiste na oferta de apoio psicológico e psiquiátrico a perseguidos e familiares em 
algumas cidades. ${ }^{35} \mathrm{O}$ programa brasileiro de reparações é, na verdade, um dos maiores programas de reparação do mundo. Dados do SIAFI (Sistema Integrado de Informação Financeira do Governo Federal) mostram que entre 2001 e 2010, mais de R\$ 3 bilhões foram gastos, no chamado "custo ditadura", com reparações econômicas em parcelas únicas e mensais (Cf. Torelly, 2012). Até setembro de 2014, a Comissão de Anistia havia apreciado aproximadamente de 62 mil requerimentos: destes, cerca de 35 mil foram deferidos.

Em 2007, assumiu o cargo de presidência da Comissão de Anistia o advogado Paulo Abrão Pires Junior. Além dos esforços indenizatórios, sob seu comando a Comissão de Anistia passou a desenvolver uma série de outras atividades ligadas à divulgação de seus trabalhos e à preservação da memória sobre o período autoritário. Entre as principais atividades desenvolvidas estão as Caravanas da Anistia, as Anistias Culturais, audiências públicas, sessões de oitivas, seminários, oficinas, cursos e publicações de material educativo e artigos acadêmicos (Comissão Nacional de Anistia, 2010).

Entre 2008 e 2010, 1.030 processos foram julgados em 47 Caravanas (Comissão Nacional de Anistia, 2010a, p. 16 e 51), que percorreram o país com Seminários e exposições que procuram redimir a memória de alguns dos anistiados contemplados por seus trabalhos. Os processos julgados nas Caravanas geralmente envolvem personalidades políticas de destaque nacional, regional ou local. As Caravanas percorreram 18 Estados e 30 cidades. O Relatório Anual de 2010 (Comissão Nacional de Anistia, 2010, p. 31) estima que cerca de 15 mil pessoas tenham participado de suas sessões até aquele ano.

Já As Anistias Culturais envolvem diversas atividades culturais e educativas como ciclos de debates, mostras fotográficas e de filmes, apresentação de peças teatrais etc. Um de seus principais objetivos, conforme atesta um dos relatórios da Comissão (2010, p. 17), é destacar a participação popular na "luta pela redemocratização do país" ou problematizar os mecanismos da repressão. ${ }^{36}$

Nas diversas audiências públicas que realiza, a Comissão de Anistia coleta sugestões e críticas a seu trabalho, bem como abre a possibilidade para a sociedade civil compartilhar seu entendimento a respeito da repressão e da luta contra o autoritarismo

\footnotetext{
${ }^{35}$ A ideia do projeto Clínicas do Testemunho foi resultado das várias cooperações internacionais levadas adiante pela Comissão de Anistia. Inspirada em experiências de países como Chile e Colômbia, a Comissão passou a fornecer, a partir de 2011, apoio psicológico e psiquiátrico a vítimas da perseguição política durante a repressão.

${ }^{36}$ A título meramente ilustrativo, foram tema de algumas destas mostras culturais "Homenagem aos perseguidos políticos, filhos de militantes"; "Memórias do Feminino: vivências, resistência e protagonismo das mulheres na luta por democracia"; "40 anos do Ato Institucional n. 5".
} 
estatal. As sessões de oitiva visam a tomar depoimentos de pessoas ou comunidades inteiras de alguma forma envolvidas ou que sofreram com as perseguições políticas.

Entre as publicações educativas, pode-se citar, por exemplo, a cartilha Liberdades Democráticas: Levante esta Bandeira, editado pela Comissão de Anistia em parceria com a Secretaria Nacional de Juventude da Presidência da República, com o objetivo de divulgar em linguagem acessível os mecanismos da repressão e a resistência civil contra ela. No meio acadêmico, além das publicações semestrais da Revista Anistia Política e Justiça de Transição, integrantes da Comissão têm publicado uma série de livros e artigos científicos em revistas de grande impacto e em cooperação com outros núcleos de pesquisa e universidades no mundo todo.

Todas estas ações, especialmente as Caravanas da Anistia, as Anistias Culturais e as publicações acadêmicas em torno da justiça de transição têm tido certamente papel central na difusão do tema no país, contribuindo para sensibilizar o público em geral e a comunidade acadêmica e jurídica em particular para a questão da memória, da verdade e da justiça como diferentes formas de accountability sobre as violações praticadas durante o período repressivo.

A partir de 2010, também o projeto Marcas da Memória passou a ser desenvolvido a partir da Comissão de Anistia. Com o apoio de núcleos de pesquisa de universidades públicas brasileiras, o projeto conta basicamente com quatro tipos de ações: as audiências públicas, destinadas a tomar depoimentos e suscitar discussões sobre o período militar e as políticas do presente; a história oral, que consiste na realização de entrevistas com perseguidos políticos e familiares para edição de livro a respeito ${ }^{37}$; as chamadas públicas, que consistem na seleção de projetos da sociedade civil pela Comissão de Anistia para realização de documentários, exposições fotográficas, palestras, musicais, preservação de acervos, lugares de memória, produções teatrais e materiais didáticos sobre a repressão e a resistência ${ }^{38}$; e por fim as publicações de coleções de livros acadêmicos ou didáticos sobre a ditadura, personalidades perseguidas e a justiça de transição. ${ }^{39}$

\footnotetext{
${ }^{37} \mathrm{O}$ livro, organizado por uma equipe de pesquisadores financiados pela Comissão, foi publicado com o título História Oral da Anistia no Brasil (Montenegro, Rodeghero e Araújo, 2012), e pode ser obtido pelo endereço eletrônico: http://www.justica.gov.br/central-de-conteudo/anistia/anexos/historia-oral-miolo.pdf.

${ }^{38}$ Entre os documentários financiados pela Comissão de Anistia estão aqueles reunidos na série dirigida por Silvio Tendler sobre a ditadura militar, entre eles "Advogados contra a Ditadura: por uma questão de justiça" (2014) e "Militares da democracia: os militares que disseram 'não"” (2014). Ao lado de outros, estes filmes foram disponibilizados pelo próprio Ministério da Justiça pelo site do Youtube, respectivamente, nos endereços eletrônicos: https://www.youtube.com/watch?v=fhRJxeFfbYM

https://www.youtube.com/watch?v=6hD8JIHbu3w. Último acesso: 24 de maio de 2015.

${ }^{39}$ Entre algumas das publicações mais importantes da Comissão de Anistia no âmbito do projeto Marcas da Memória estão o Livro dos Votos da Comissão de Anistia, a que vou me reportar mais adiante, os livros
} 
O Livro dos Votos, que conta com uma série de pareceres técnicos sobre casos considerados emblemáticos da jurisprudência da Comissão sobre pedidos de anistia e reparação econômica, oferece uma boa ideia da produção discursiva encampada profusamente pela Comissão de Anistia e seus integrantes. ${ }^{40}$ Ali reitera-se a ideia de que, na verdade, a reparação econômica e simbólica das violações sofridas no passado tem o condão de reconciliar o indivíduo com o Estado (Comissão Nacional de Anistia, 2013, p. 08). Na apresentação do livro, Paulo Abrão, o presidente da Comissão, escreve:

“O único sentido que o termo 'reconciliação' pode ter numa democracia é esse: o Estado reconhece seu erro e pede perdão à vítima, na esperança de reconquistar a confiança cívica que perdeu quando se desviou de finalidade em uma empresa autoritária. Reconciliação significa, nos trabalhos da Comissão de Anistia, este retorno da confiança cívica das vítimas nas instituições do Estado que antes foram usadas para violar seus direitos" (Paulo Abrão, 2013, p. 18-19).

Trata-se de uma tentativa de reclassificação do termo (re)conciliação, assim como a Comissão e seus membros se engajam na mudança do conceito de anistia: a partir dos esforços indenizatórios do Estado brasileiro, a (re)conciliação deixaria de significar o improvável entendimento entre opressores e vítimas, mas sim um pedido de desculpas do Estado pelas violações do passado, podendo então voltar a ganhar a confiança de seus cidadãos, inclusive daqueles que foram perseguidos por agentes públicos. Fica claro que, ao articular reconciliação com reconhecimento dos suplícios sofridos por opositores do regime militar e infligidos por agentes públicos, bem como com a reconquista da confiança cívica nas instituições, a Comissão de Anistia tenta aproximar esta (nova) categoria de (re)conciliação à elaboração normativa de Pablo de Greiff a respeito, tratada no capítulo anterior. $\mathrm{O}$ livro também investe na relação entre memória e não repetição, já sustentada pelas obras editadas pela CEMDP. Mais do que isso, sustenta que o passado precisa ser lembrado e abordado "sob os auspícios democráticos" (ibid. Id.).

Caravanas da Anistia: o Brasil pede perdão (organizado por Maria José Coelho e Vera Rotta, 2012), Vala clandestina de Perus (Comissão de Anistia, 2012), Paulo Freire, anistiado politico brasileiro (Comissão de Anistia e Instituto Paulo Freire, 2012) e Rádio Libertadora: a palavra de Carlos Marighella (organizado por Iara Xavier Pereira, 2012). Outra publicação importante da Comissão de Anistia, embora não exatamente no âmbito do projeto Marcas da Memória, é a já mencionada edição semestral do periódico acadêmico Revista Anistia Politica e Justiça de Transição, que pode ter sua versão digital baixada gratuitamente diretamente do site do Ministério da Justiça. Aliás, boa parte dos livros (se não todos) publicados no âmbito do Marcas da Memória, além da publicação em papel, foram também disponibilizados pelo Ministério da Justiça gratuitamente via internet.

${ }^{40}$ Dentre cerca de 70 mil casos processados pela Comissão de Anistia até 2013, foram publicados 115 votos de relatores no Livro dos votos. Estes votos foram selecionados ou por tratarem de avaliação de pedidos de anistia e/ou reparação feitos por personalidades bastante conhecidas da oposição à ditadura ou porque são representativos da jurisprudência da Comissão para determinados casos. 
No mais do livro, entretanto, o leitor tem diante de si - mesmo nestes casos considerados emblemáticos e com forte significado político - a elaboração predominantemente técnica de pareceres e votos sobre a aplicabilidade ou não da concessão de anistia e indenização aos requerentes, sempre com base nos termos estritos da lei e dependendo da qualidade das provas apresentadas pelo requerente ou produzidas pela própria Comissão. Mesmo neste quesito da técnica e da jurisprudência envolvidas na avaliação destes pedidos, o livro pode passar uma impressão um tanto distorcida dos trabalhos da Comissão porque traz muito mais votos de deferimentos do que de indeferimentos de anistia e reparação. O Relatório Anual de 2010 (Comissão de Anistia, 2010, p. 119), por exemplo, traz dados acerca da porcentagem de concessão ou indeferimento de anistias conforme o ministro da Justiça à frente do Ministério: a porcentagem de indeferimento varia de cerca de pouco mais de 20\% (quando Paulo de Tarso Ribeiro foi ministro da Justiça entre julho de 2002 e janeiro de 2003) e mais de $42 \%$ (quando Márcio Thomaz Bastos esteve à frente da pasta entre janeiro de 2003 e março de 2007). ${ }^{41}$ A oscilação conforme o ministro parece bastante grande. De todo modo, a taxa de indeferimento é sempre relativa e consideravelmente alta, diferentemente da impressão que pode passar o Livro dos votos.

A Comissão de Anistia tem consciência do seu papel central na implementação do chamado "direito à memória e à verdade": "para além da função julgadora, [a Comissão] exerce importante papel na gestão de políticas de memória e de educação para a democracia" (Comissão Nacional de Anistia, 2010, p. 07). Na ausência de uma Comissão da Verdade, a Comissão de Anistia assumiu, desde 2007 (quando Paulo Abrão passa a presidi-la), várias funções geralmente associadas pela literatura às comissões da verdade. E, vale dizer, como veremos adiante, mesmo depois da criação da Comissão Nacional da Verdade (CNV) em 2011 (e sua implementação um ano mais tarde), as políticas de memória encampadas pela Comissão de Anistia puderam suprir algumas ausências no trabalho da $\mathrm{CNV}$, especialmente no que diz respeito à atuação da oposição política e da luta armada, embora sem a mesma repercussão na mídia de que pôde desfrutar a CNV.

Se não a maioria dos trabalhos acadêmicos mais recente, pelo menos os mais influentes, sobre a Comissão de Anistia e políticas de memória, verdade, justiça e reparações foram publicados por integrantes, ex-integrantes ou pessoas que já trabalharam

\footnotetext{
${ }^{41}$ Nesta conta, não levei em consideração o $0,00 \%$ de indeferimento de pedidos por parte da Comissão de Anistia quando Miguel Reale Júnior era Ministro da Justiça, pois durante seu curto mandato em 2002, apenas quatro pedidos foram apreciados (o dado não traz, neste sentido, uma fonte estatisticamente significativa).
} 
para a própria Comissão de Anistia. Além de possuírem uma relação institucional em comum, são também bastante afinados no que se refere à interpretação sobre as políticas públicas de justiça transicional do país, bem como no que diz respeito aos princípios e horizontes normativos do campo, de modo que resta difícil a trabalhos monográficos independentes - mesmo que centrados especificamente no desempenho da Comissão de Anistia (o que não é o caso aqui) - não se verem influenciados também pelas publicações deste grupo. Hoje, se o termo "justiça de transição" e seus horizontes normativos ganharam os contornos de um "campo" de pesquisa e atuação no país, isso se deve fundamentalmente aos trabalhos da Comissão de Anistia e, especificamente no que diz respeito ao ambiente acadêmico, às publicações da Revista Anistia Política e Justiça de Transição.

A propósito de comentar os seminários e parcerias com universidades e centros de pesquisa, a Comissão de Anistia reconhece seu engajamento na formação de quadros. No Relatório Anual de 2010 (Comissão Nacional de Anistia, 2010, p. 42), por exemplo, lê-se: "A atividade teve como objetivo propiciar o conhecimento e o debate sobre o processo de justiça de transição brasileiro junto a advogados e defensores de direitos humanos, com potencial para desenvolverem a temática da justiça de transição no âmbito das ONGs, movimentos e organizações sociais para as quais atuam".

Ainda que exista relativamente pouco espaço na grande mídia para o tema da justiça de transição e especialmente para as importantes políticas de memória realizadas pela Comissão de Anistia, o fato é que ela tem desempenhado papel central na formação de opinião de pesquisadores, operadores do direito e agentes de políticas públicas envolvidos com a justiça de transição no Brasil. Integrantes da Comissão de Anistia também compuseram o Grupo de Trabalho encarregado pelo presidente Lula para elaborar o projeto de criação da Comissão da Verdade, a partir da proposta da sociedade civil incorporada pelo Plano Nacional de Direitos Humanos 3 (PNDH-3). Também participaram do GT a Casa Civil da Presidência da República, a Secretaria de Direitos Humanos, o Ministério da Defesa, a Comissão Especial de Mortos e Desaparecidos Políticos e um membro da sociedade civil.

A partir de 2007, então, o viés fundamentalmente patrimonialista de que falava Mezarobba (2007) para caracterizar os trabalhos da Comissão de Anistia passou a ser superado. Em diversas ocasiões na imprensa, inclusive, Paulo Abrão também tem defendido o julgamento de agentes públicos que violaram direitos humanos durante o regime militar, contrariando a posição assumida pelos governos também do PT durante 
muitos anos. Para fundamentar juridicamente sua posição, Paulo Abrão (2012, p. 53) destaca que o artigo $8^{\circ}$ do ADCT só fala em anistia para os que "foram atingidos, em decorrência de motivação exclusivamente política", sem fazer qualquer menção a uma extensão dos direitos ali previstos aos agentes públicos que tenham cometido crimes contra opositores do regime. Neste sentido, para ele, a Constituição de 1988 não teria recepcionado a Lei de Anistia nem a parte da Emenda Constitucional n. 26/1985 que tratava do tema. ${ }^{42}$

Paulo Abrão e Marcelo Torelly, que assinaram juntos dezenas de artigos, também têm investido em uma disputa pelo conceito de anistia. Em um destes textos (Abrão e Torelly, 2012), os autores tentam imprimir uma narrativa histórica em que o conceito de anistia passaria de sua associação ao esquecimento e à impunidade para uma associação às noções de "memória, verdade e justiça". Mais uma vez, ali enfrentam o que chamam de uma "literatura precipitada" que tentaria ligar o processo de reparação no Brasil insistentemente à figura do esquecimento. ${ }^{43}$ Para Paulo Abrão (2012), o fundamento constitucional para as comissões de reparação rompe com o esquecimento, pois não é possível reparar sem o resgate da memória.

\section{Considerações finais do capitulo}

Dentro da estrutura do Estado brasileiro, os integrantes da Comissão de Anistia são os que mais elaboram formulações no sentido de mudar de forma significativa o entendimento de alguns das categorias centrais do processo justransicional brasileiro. Mas, do ponto de vista mais amplo do governo federal, embora eles desempenhem políticas

\footnotetext{
${ }^{42}$ Em muitos outros textos, Paulo Abrão e outros integrantes da Comissão de Anistia defendem a revisão da Lei de Anistia e a punição de agentes públicos envolvidos em violações aos direitos humanos durante o período da ditadura militar. O tema será debatido de forma mais aprofundada no capítulo seguinte. De todo modo, vale mencionar aqui a insistência da Comissão neste ponto e a força que sua posição começa a ter mesmo dentro da cúpula do governo federal, como veremos a seguir.

${ }^{43}$ Por outro lado, vale lembrar que, à época da edição das leis em1995 e 2002 ainda não havia qualquer perspectiva da criação de uma Comissão da Verdade e muito menos do julgamento e condenação de agentes públicos envolvidos em violações aos direitos humanos durante a ditadura. Por isso vale sim a interpretação, por exemplo, de Janaína Teles (2005), segundo a qual, pelo menos em sua fundamentação política, estas leis repunham o aspecto de "pacificação nacional" (ou pelo menos não o desafiavam claramente) contido no projeto de anistia do governo militar aprovado em 1979. Não havia qualquer previsão de se encetar um debate público das violações que seriam eventualmente investigadas a propósito dos processos de anistia e reparações. Essa dimensão passa a ganhar força apenas por meio da atuação da nova configuração política nos quadros das comissões de reparação durante o primeiro governo Lula, pois a partir daí há um maior engajamento em alçá-las à condição de promotoras da memória.
} 
públicas extremamente importantes no contexto dos direitos humanos, estes integrantes representam uma voz de vanguarda. Constituem ainda uma voz dissonante em relação a aspectos delicados da justiça de transição no Brasil frente às posições da cúpula dos governos federais.

Apenas para citar uma ocasião em que Dilma Rousseff se referiu à Lei de Anistia, em discurso na data que marcava o quinquagésimo aniversário do golpe de 1964, a presidenta afirmou que "reconhece e valoriza os pactos políticos que nos levaram à redemocratização". ${ }^{44} \mathrm{Na}$ mesma oportunidade, ainda de forma muito parecida com os discursos dos presidentes da "distensão" (Geisel e Figueiredo) e da transição (Tancredo e Sarney), e reportando-se indiretamente a uma recepção constitucional da Lei de Anistia, Dilma disse que "nós reconquistamos a democracia à nossa maneira, por meio de lutas e de sacrifícios humanos irreparáveis, mas também por meio de pactos e acordos nacionais, muitos deles traduzidos na Constituição de 1988”. E continuou: “Assim como eu respeito e reverencio os que lutaram pela democracia, enfrentando a truculência ilegal do Estado [...], também reconheço e valorizo os pactos políticos que nos levaram à redemocratização".

Por outro lado, apesar de ainda acolher a antiga concepção de conciliação enquanto pacto e apaziguamento, já não entende que ela deveria produzir esquecimento. Lembrando o discurso que proferiu a propósito da instalação da Comissão da Verdade dois anos antes, disse: "a palavra 'verdade' é exatamente o oposto do esquecimento", “[...] é algo tão forte que não dá guarida para o ressentimento, ódio e nem tão pouco para o perdão. [...] Ela é só e sobretudo o contrário do esquecimento. É memória e é história”. Para a presidenta, “o dia de hoje exige que nós nos lembremos e contemos o que aconteceu. Devemos isso aos que morreram e desapareceram. Devemos aos torturados e aos perseguidos, às suas famílias, a todos os brasileiros".

Neste sentido, a presidenta absorve a mudança da anistia enquanto esquecimento para a justiça enquanto memória. Mas ainda insiste na questão da conciliação, que parece ser a categoria mais resiliente no contexto justransicional brasileiro. Ainda está muito presente a ideia de que a anistia deitou o pacto político sem o qual não seria possível a

\footnotetext{
${ }^{44}$ Esta e as próximas citações de Dilma Rousseff neste e no próximo parágrafo dizem respeito à reportagem de MONTEIRO, T.; DECAT, E.; CARAM, B. "Dilma sinaliza que não é favorável à alteração da Lei da Anistia”. Jornal Estadão, São Paulo, 31 de mar. 2014. Caderno Política. Disponível em: http://politica.estadao.com.br/noticias/geral,dilma-sinaliza-que-nao-e-favoravel-a-alteracao-da-lei-daanistia,1147383. Último acesso em 24 de fevereiro de 2015.
} 
redemocratização. Ela seria quase um pacto inicial, um "contrato social”, apesar de saberse de todos os problemas de legitimidade que cercavam tal "pacto".

Ao comentar a criação da Comissão da Verdade, o ex-presidente Fernando Henrique Cardoso também mudou significativamente seu entendimento sobre a anistia enquanto esquecimento, mas manteve firme a posição da (re)conciliação: "Eu acho que a presidente [Dilma] falou por todos nós, é um dia importante para o Brasil, com esse espírito de reconhecer a verdade, guardar na memória e ao mesmo tempo abrir as portas para uma reconciliação. Aqui é uma questão de Estado, não é política", afirmou. Para logo em seguida emendar: "Uma coisa é a Justiça, outra a memória. E aqui se trata de ver a memória, a interpretação que cada um dará, mas os fatos são os fatos, a comissão tem de revelar os fatos." 45

Fernando Henrique Cardoso, Lula e Dilma Rousseff, ao se reportarem à anistia e às políticas públicas de justiça transicional, quase invariavelmente se sentem compelidos a se referirem à inexistência de um "revanchismo" nas políticas. Isso repercutiu também no texto da Lei dos Desaparecidos e, como veremos, na lei que criou a Comissão da Verdade, as quais, ao se reportarem à categoria de "conciliação", inegavelmente carregam, ao menos em parte, os sentidos políticos que por décadas governos militares e civis lhe aportaram.

Recentemente, porém, atestando a força que tem ganhado a posição da Comissão de Anistia dentro do governo federal, durante a campanha eleitoral de 2014 para a Presidência da República, o PT veiculou propaganda de governo defendendo a revisão da Lei de Anistia e a punição de violadores de direitos humanos durante a ditadura. ${ }^{46}$ Entretanto, num momento de conjuntura política altamente desfavorável a colocar em prática posições como estas, será bem provável que o governo não tenha condições de levar adiante mais esta promessa. ${ }^{47}$ A posição oficial do governo continua a ser aquela

\footnotetext{
${ }^{45}$ Cf. MOURA, R.; MONTEIRO, V.; ROSA V. "Comissão da Verdade abre portas à conciliação, diz FHC”. Jornal Estadão, São Paulo, 16 maio 2012. Caderno Política. Disponível em: http://politica.estadao.com.br/noticias/geral,comissao-da-verdade-abre-portas-a-conciliacao-diz-fhc, 873765. Último acesso em 24 de fevereiro de 2015.

${ }^{46}$ Cf. HAUBERT, M. "PT defende revisão da Lei de Anistia em programa de governo de Dilma". Folha de São Paulo, São Paulo, 27 maio 2014. Caderno Poder. Disponível em: http://www1.folha.uol.com.br/poder/2014/05/1460621-pt-defende-revisao-da-lei-de-anistia-emprograma-degoverno-de-dilma.shtml. Último acesso em 24 de fevereiro de 2015.

${ }^{47}$ Este é pelo menos o cenário em princípios de 2015. Do ponto de vista da conjuntura política, o momento é muito pouco propício para a adoção de medidas tão progressistas quanto polêmicas como esta. Muitos são os fatores que conspiram para a conformação desta conjuntura: a eleição de um Congresso hiperfragmentado partidariamente e bastante conservador relativamente à legislatura anterior; escândalos de corrupção envolvendo cifras bilionárias na Petrobrás e políticos da base aliada; e um cenário de recessão econômica virtual que persiste paralelamente à adoção de um pacote de austeridade e aperto fiscal.
} 
expressa pela presidente Dilma Rousseff em diversas e esparsas declarações e, principalmente, aquela veiculada na atuação da Advocacia Geral da União em processos judiciais defendendo não só a constitucionalidade in abstrato do aspecto bilateral da anistia brasileira, mas também antigos agentes da repressão em casos concretos (como veremos no próximo capítulo).

Levando em conta os contornos do esforço indenizatório do Estado brasileiro, Loche (2003, p. 38) e Mezarobba (2007, p. 313) consideram que as reparações, por possuírem um caráter predominantemente privado, e por produzirem desconfianças em relação à justiça dos valores pagos, prestaram-se mais como uma forma de "compra do silêncio" das vítimas e dos familiares do que de elucidação da verdade e de produção de uma memória redimida da luta contra a ditadura. Para Heloisa Greco (2009), o abandono das ideias de revolução, socialismo e mesmo de transformação profunda das estruturas de dominação social teria levado a esquerda agora no poder federal a entrar no "espaço do instituído", inclusive no que se refere à memória sobre o período militar. Segundo esta autora, a mídia também teria desempenhado papel significativo na "estratégia do esquecimento" (Greco, 2009, p. 532).

Mas da época em que estes trabalhos foram publicados para cá, o cenário da justiça de transição brasileira mudou bastante. As demandas pela implementação das expectativas normativas do campo no Brasil ganharam muito em politização, extrapolando o círculo restrito do engajamento dos familiares. Entre os movimentos mais ativos neste cenário destacam-se, por exemplo, a Frente de Escracho Popular e o Cordão da Mentira, bem como os comitês estaduais de Memória, Verdade e Justiça. Em 2008, o Conselho Federal da OAB ajuizou uma ação para ver declarada a inconstitucionalidade da impunidade aos agentes da repressão garantida pela Lei de Anistia. Houve também uma mudança significativa na legislação de acesso à informação, tornando-a mais transparente, com prazos de sigilo menores e sem a possibilidade de segredo eterno. O Ministério Público parou de arquivar as representações que diziam respeito a crimes cometidos por agentes do Estado durante a ditadura e começou a mover ações para a tentativa de julgamento e condenação destes agentes. E por último, mas não menos importante, o governo instaurou uma Comissão Nacional da Verdade.

Mesmo no que diz respeito aos trabalhos das comissões de reparação, esta literatura tem merecido uma revisão. Por exemplo, em perspectiva comparada com outros países do Cone Sul, as reparações no Brasil tiveram uma abrangência bastante significativa em relação às vítimas e familiares que experimentaram algum tipo de 
prejuízo em função de perseguição política e em relação também aos valores pagos a título de indenização. Por outro lado, também é verdade que, em países como Argentina e Chile, as reparações econômicas foram calculadas com base no sofrimento das vítimas. ${ }^{48} \mathrm{Já}$ nas reparações pagas no Brasil, houve para alguns casos uma desigualdade na valorização das vítimas e na consideração dos suplícios sofridos.

Do ponto de vista do alcance da justiça de transição no Brasil, o engajamento das comissões de reparação em políticas de memória tem rendido muitos frutos. Nas palavras do próprio presidente da Comissão de Anistia: "Se, originalmente, a Comissão de Anistia foi pensada como órgão de reparação, sua atuação lhe transformou em algo maior: um espaço de reconhecimento da verdade histórica e de produção ativa de memória" (Paulo Abrão, 2013, p. 19). Paulo Abrão tem plena consciência de sua atuação na formação de quadros e na "nacionalização" do debate sobre justiça de transição no Brasil: “... a Comissão de Anistia transformou-se em um importante ator institucional pró-justiça de transição dentro do Estado brasileiro" (ibid. id.).

De uma visão acerca de uma função (se não apenas, principalmente) patrimonialista de que falava o ex-presidente Fernando Henrique Cardoso em entrevista que concedeu a Glenda Mezarobba (2006), caminhamos para uma tarefa assumida pelas comissões de reparação de, além de conceder indenizações, redimir algumas narrativas antes silenciadas ou que sofriam uma série de estigmatizações, de modo que, sobretudo a Comissão de Anistia, passou a ser o carro-chefe da preservação oficiosa da memória sobre a repressão do regime militar, pelo menos até a criação da Comissão da Verdade. Por outro lado, porém, as publicações produzidas pelas comissões de reparação, apesar de divulgarem o reconhecimento do Estado a respeito das violações do passado, não individualizaram os responsáveis pelas violações. Até então, mesmo com os esforços das comissões de reparação em torno da valorização da memória, a atribuição de responsabilidade recaía fundamentalmente ao Estado, um ente abstrato. A tarefa de responsabilização concreta passaria a ficar a cargo, a partir de 2012, da Comissão da Verdade.

\footnotetext{
${ }^{48} \mathrm{Na}$ Argentina, por exemplo, uma das unidades de cálculo eram os dias de encarceramento (Mezarobba, 2007, p. 307).
} 


\section{Capítulo 3. A jurisprudência de Tribunais brasileiros na esfera penal}

Este capítulo, atinente ao desenvolvimento do eixo "justiça" no processo justransicional brasileiro, tem por objeto privilegiado o julgamento do STF em 2010 no bojo da Arguição de Descumprimento a Preceito Fundamental (ADPF) n. 153. ${ }^{1}$ De forma parecida com o capítulo anterior, o objetivo central aqui é reconstruir criticamente as representações de ministros do STF, advogadosgerais da União, procuradores-gerais da República e outros atores estatais a respeito do processo de redemocratização no Brasil, do papel da anistia neste processo e dos alcances e limites da justiça de transição no país.

A propósito da discussão a respeito deste julgamento, outros casos decididos pela Suprema Corte brasileira também serão comentados, como as Extradições 974, 1.150 e 1.278, a ADPF 320, entre outros, bem como o julgamento da Corte Interamericana de Direitos Humanos (CrIDH) no caso Gomes Lund e outros $v s$. Brasil ${ }^{2}$, na medida em que todos dialogam com a ADPF 153. Por fim, também será pertinente retratar em linhas gerais o estado das ações penais ajuizadas pelo Ministério Público Federal (MPF) contra agentes públicos suspeitos de graves violações aos direitos humanos durante a ditadura militar e a forma bastante variada com que a Justiça Federal tem lidado com elas em suas diferentes regiões de atuação.

O foco central será a ADPF 153 basicamente por três motivos: primeiro porque, sendo o STF a instância mais alta do Judiciário brasileiro, sua jurisprudência tem

\footnotetext{
${ }^{1}$ A função da ADPF é julgar a recepção de uma norma pela Constituição, atribuindo os mesmos efeitos práticos de uma Ação Declaratória de Inconstitucionalidade (ADI). Assim como a ADI, portanto, a ADPF é uma espécie de controle de constitucionalidade (ou revisão judicial) concentrado, mas, diferentemente daquela, não diz respeito a leis promulgadas depois da Constituição em vigor, senão editadas antes dela.

${ }^{2}$ Também conhecido como "caso Guerrilha do Araguaia".
} 
naturalmente grande impacto sobre decisões de instâncias inferiores; segundo porque, quando a Corte julga um processo de controle concentrado de constitucionalidade, como é o caso da ADPF 153, sua decisão tem efeito erga omnes, isto é, vale para todo o território nacional; e em terceiro lugar porque, em casos de controle concentrado de constitucionalidade, a Corte exerce uma função não apenas "jurídico-judicial”, mas também e mesmo predominantemente "político-judicial", o que se reflete, inclusive, no registro da argumentação dos ministros nestes casos. ${ }^{3}$

De todo modo, será importante verificar também o estado das ações penais ajuizadas pelo MPF porque as discussões, entendimentos e decisões que têm sido suscitados a partir delas na Justiça Federal podem afetar futuramente a própria visão do STF a respeito do tema. ${ }^{4}$

\footnotetext{
${ }^{3}$ Sobre a atuação "política" de Cortes Constitucionais, ver, por exemplo, Stone Sweet (2000) e Ginsburg (2003), e, especificamente sobre a atuação "política" do STF no controle concentrado de constitucionalidade, ver, por exemplo, Arantes e Couto (2009) e Taylor (2008).

${ }^{4}$ Por uma questão de recorte de pesquisa, para que seu escopo não fique ainda maior do que já é, preferi manter, neste capítulo, o foco nas ações penais. Entretanto, como foi destacado no capítulo 1, a dimensão da "justiça", na justiça de transição, pode ser buscada não só por via de processos judiciais, mas também por outras medidas, às vezes prioritariamente associadas a outros mecanismos, mas que também trazem uma dimensão de justiça restaurativa (como as indenizações a perseguidos políticos em comissões de reparação ou o reconhecimento de seus suplícios em comissões da verdade) e retributiva (como a identificação de responsáveis por violações a direitos humanos em comissões da verdade). Por exemplo, no capítulo 2 nos reportamos, dentre outras coisas, ao reconhecimento, pelo Estado brasileiro, dos suplícios sofridos pelos perseguidos políticos; e, no capítulo 4, dentre outras coisas, veremos a responsabilização, pela Comissão Nacional da Verdade, de agentes da repressão. Além disso, mesmo do ponto de vista dos processos judiciais, a dimensão da justiça pode ser buscada não apenas na esfera penal, mas também na cível e mesmo na esfera do direito administrativo. Muitos processos civis foram ajuizados por perseguidos e familiares de perseguidos políticos no Brasil contra agentes da repressão. Nestas ações, os autores pleiteiam basicamente dois objetivos: ou uma indenização ou uma declaração da Justiça reconhecendo as violações perpetradas (ou ambas as coisas). Um dos processos mais conhecidos é a ação declaratória movida pela família Teles contra o coronel reformado Carlos Alberto Brilhante Ustra. Neste caso, em 2012, o Tribunal de Justiça de São Paulo decidiu, por unanimidade dos três votos da turma da $1^{\text {a }}$ Câmara de Direito Privado que ficou responsável pelo julgamento, basicamente confirmar a sentença de primeira instância no mérito, a qual havia determinado que entre os autores (excetuando-se os filhos do casal Teles) e o ex-coronel havia "uma relação jurídica de responsabilidade civil, nascida da prática de ato ilícito, gerador de danos morais". Isto é, o Judiciário paulista reconheceu a existência da prática de tortura pelo coronel reformado contra aqueles autores. No momento, recursos estão pendentes de julgamento nas Cortes superiores (primeiro no STJ e muito possivelmente, mais tarde, no STF). As movimentações deste processo podem ser acompanhadas pelo site do Tribunal de Justiça de São Paulo, pelo link:

http://esaj.tjsp.jus.br/cpo/sg/search.do? conversationId=\&paginaConsulta=1\&localPesquisa.cdLocal=$1 \&$ cbPesquisa=NMPARTE $\&$ tipoNuProcesso $=$ UNIFICADO\&dePesquisa $=J a n a \% E D n a+d e+A l m e i d a+T e l e s$. Último acesso em 25 de março de 2015.
} 


\section{1) A ADPF 153 e as Extradições 974, 1.150 e 1.278}

Em 2008, o Conselho Federal da OAB protocolou uma ADPF ( $n^{\circ} 153$ ) na qual realizava dois pedidos alternativos: ou que a Suprema Corte considerasse que a expressão "crimes conexos" (contida no parágrafo $1^{\circ}$ do artigo $1^{\circ}$ da Lei de Anistia) não teria o condão de abranger, nos benefícios da lei, os agentes da repressão; ou, uma vez entendendo aquela expressão como ensejando esta abrangência, que a Corte considerasse então o dispositivo como não recebido pela Constituição de 1988. Na prática, o pedido, se atendido, teria o efeito de extirpar do sistema judicial qualquer mecanismo, fosse uma interpretação do dispositivo ou o próprio dispositivo, que sustentasse a isenção de responsabilidade penal e administrativa dos agentes da repressão militar. Neste sentido, a expressão "crimes conexos", encontrada no $\S 1^{\circ}$ do art. $1^{\circ}$ da Lei de Anistia, não poderia estender os benefícios da lei àqueles agentes. ${ }^{5}$ Em 2010, por sete votos a dois, o STF julgou a ação improcedente. ${ }^{6}$

Este julgamento do STF suscitou a produção de dezenas, talvez centenas de artigos, sobretudo na área do Direito, a seu respeito. ${ }^{7}$ Porém, diferentemente do objetivo da maioria desta literatura, o foco central aqui é recuperar não apenas a discussão jurídica que se desenvolveu em torno do julgamento, mas principalmente analisar criticamente o discurso jurídico-político a respeito do papel da anistia e da conciliação no processo de transição para a democracia no Brasil. ${ }^{8}$

Também será feita uma crítica ao modo de abordagem de boa parte dos ministros no julgamento, que em sua grande maioria não discutiram de forma aprofundada a

\footnotetext{
${ }^{5}$ A ação ajuizada pelo Conselho Federal da OAB foi assinada pelo jurista Fábio Konder Comparato, patrono também da ação civil da família Teles contra o coronel aposentado Carlos Alberto Brilhante Ustra e responsável pela elaboração do Projeto de Lei de autoria da deputada federal Luíza Erundina (PSB-SP) que visava a revogar a chamada bilateralidade ou reciprocidade da isenção de responsabilidade penal contida na anistia de 1979. Veremos mais sobre este e outros projetos de lei neste sentido mais adiante neste capítulo.

${ }^{6}$ Cf. STF (2010): trata-se do Inteiro Teor do Acórdão do STF de 2010 no bojo da ADPF 153 (com a Ementa, o debate e os votos de todos os ministros que participaram do julgamento). Disponível em: http://www.stf.jus.br/portal/geral/verPdfPaginado.asp?id=612960\&tipo=AC\&descricao=Inteiro\%20Teor\%2 0ADPF\%20/\%20153. Último acesso em 16 de março de 2015. De agora em diante, vou me referir aos votos dos ministros com base na paginação deste documento.

${ }^{7}$ Ver, por exemplo, Flávia Piovesan (2010 e 2014), Deisy Ventura (2011), Luiz Flávio Gomes e Valério de Oliveira Mazzuoli (2014), Marcelo Torelly (2012, com capítulo especial sobre o julgamento), Ricardo Silveira Castro (2014) e Marlon Alberto Weichert (2014). Também escrevi um texto intitulado "Da relação entre constitucionalismo e democracia: um estudo da decisão do STF sobre a constitucionalidade da anistia brasileira a partir de uma ótica habermasiana da justiça", que foi apresentado no II Seminário Discente da Pós-Graduação em Ciência Política da USP e cuja segunda versão está no prelo para ser publicada em livro intitulado Jürgen Habermas: publicidade, direitos humanos e sociedade civil, organizado pelos professores Rainer Schmidt (Universidade de Dresden) e Alessandro Pinzani (UFSC).

${ }^{8}$ O jurista Marcelo Cattoni de Oliveira também tece comentários a respeito em alguns de seus artigos: ver, por exemplo, Cattoni de Oliveira (2010) e Cattoni de Oliveira e David Francisco Lopes Gomes (2014).
} 
legislação e a jurisprudência de Cortes internacionais a respeito da matéria. E que apresentaram também uma visão do direito fundamentalmente pautada numa noção "ética" do direito, fundada num alegado horizonte de aspirações sociais do qual os magistrados superiores seriam os grandes intérpretes, em oposição a uma visão "principiológica" do direito, que seria pautada em mandamentos de validade universal. ${ }^{9}$

Contudo, na medida em que pelo menos parte do objeto da ADPF 153 dialoga com algumas Extradições concedidas pelo STF nos últimos anos, começaremos por um breve relato destas Extradições. Elas também são importantes porque tocam no ponto central da argumentação do MPF (que será explorada mais tarde) para embasar o ajuizamento das primeiras ações penais contra agentes da repressão: a questão do crime permanente no caso de desaparecimento de perseguidos políticos.

\subsection{1) As Extradições 974, 1.150 e 1.278}

As Extradições 974, 1.150 e 1.278 foram todas requeridas pela Argentina ao governo brasileiro e tiveram como saldo a conformação de uma jurisprudência do STF a respeito da tipificação, no Brasil, do crime de desaparecimento forçado (que possui um tipo penal específico na Argentina e em outros países, mas não no Brasil). Em todas estas Extradições, a questão fundamental, para o STF, era determinar o equivalente brasileiro das práticas delituosas em questão e se, uma vez determinado o tipo penal, tratava-se ou não de caso de prescrição. A partir da reviravolta ocorrida no primeiro julgamento, em que o ministro relator Marco Aurélio Mello foi contestado pelo voto do ministro Ricardo Lewandowski, que convenceu a maioria de seus colegas, o STF passaria a considerar o crime de sequestro como o equivalente brasileiro do desaparecimento. $\mathrm{O}$ crime de sequestro, sem a apresentação dos restos mortais ou de sentença que determine com razoável precisão quando ocorreu a morte da vítima, deve ser entendido como um crime permanente, isto é, ainda em curso, e por isso não suscetível à prescrição. ${ }^{10}$

Neste primeiro caso, em agosto de 2009, o plenário do STF autorizou o governo brasileiro a extraditar o major uruguaio Manuel Juan Cordeiro Piacentini para a Argentina. O militar era acusado de ter participado da Operação Condor, constituída nos anos 1970

\footnotetext{
${ }^{9} \mathrm{Na}$ visão de Habermas (2003b), a "ética" diz respeito ao conjunto de valores compartilhados por uma comunidade; já os "princípios" se referem a um sistema de regulação universalizável. O desenrolar desta crítica será feito no final do capítulo.

${ }^{10}$ A Convenção Interamericana sobre Desaparecimento Forçado de Pessoas ainda não foi ratificada pelo Estado brasileiro, razão pela qual a "dupla tipicidade" da conduta delituosa precisa ser classificada por outro crime no Brasil.
} 
para reprimir a oposição a regimes militares no Cone Sul da América do Sul. O ministro relator Marco Aurélio Mello, que foi voto vencido, já na época se reportava à repercussão que a matéria poderia ter no julgamento da anistia que se avizinhava:

"Se deferida esta extradição, assentar-se-á a viabilidade de persecução criminal, de responsabilidade administrativa e civil, no tocante a fatos cobertos pela anistia e, então, esvaziada na essência será esta última, não mais implicando a suplantação de quadra indesejada" (Marco Aurélio Mello, 2009, p. 11-12). ${ }^{11}$

Ricardo Lewandowski votou no sentido de que se tratava de crime permanente, uma vez que, embora tenha acontecido há mais de três décadas, muitos bebês foram tirados de suas mães no cárcere durante o regime militar argentino. Essas pessoas, hoje, estão em outra família, com nomes trocados e muitos ainda não sabem quem são seus verdadeiros pais. Neste sentido, não se poderia afirmar com certeza a morte das vítimas. $\mathrm{O}$ ministro deferiu, nos termos do parecer do Ministério Público Federal (MPF), a extradição.

Cezar Peluso acompanhou o voto divergente, desenvolvendo bastante a argumentação neste sentido e pautando-a em ampla análise de doutrina e jurisprudência. Carmen Lúcia mudou o voto que havia proferido a princípio e passou a acompanhar Lewandowski e Peluso. Depois também Joaquim Barbosa, Ayres Britto e Eros Grau seguiram os votos divergentes.

Na Extradição 1.150, julgada no começo de 2011, mais uma vez, o plenário do STF concedeu a extradição do major do Exército argentino Norberto Raul Tozzo, para ser julgado pelo Tribunal de $1^{a}$ instância de Resistência (Capital da Província do Chaco), na Argentina, por sua participação no crime conhecido como "Massacre de Margarita Belén", ocorrido em 13 de dezembro de 1976. ${ }^{12}$ Único voto discordante, o ministro Marco Aurélio posicionou-se contra a concessão da extradição, alegando que o crime ocorreu durante regime de exceção vigente no país vizinho e teve motivação política. ${ }^{13}$

Já a Extradição 1.278 foi concedida parcialmente por unanimidade pela Segunda Turma do STF em setembro de 2012. O governo argentino pleiteava que fosse extraditado

\footnotetext{
${ }^{11}$ O então ministro Menezes Direito foi o único a seguir o voto do relator. Cf. STF (2009).

${ }^{12}$ Naquela ocasião, um grupo de 22 presos políticos, em sua maioria militantes da Juventude Peronista, teria sido executado numa operação conjunta do Exército argentino e da Polícia do Chaco, em um lugar próximo à localidade de Margarita Belén, naquela província. Dos 22 presos políticos, 18 foram identificados, mas quatro continuam sendo considerados desaparecidos, pois até hoje seus corpos não foram entregues às suas famílias.

${ }^{13}$ Cf. "Concedida extradição de major argentino envolvido em massacre". Notícias STF, Brasília, 19 maio 2011. Disponível em: http://www.stf.jus.br/portal/cms/verNoticiaDetalhe.asp?idConteudo=180020. Último acesso: 25 de março de 2015.
} 
Cláudio Vallejos, acusado de tortura, homicídio, sequestro qualificado e desaparecimento forçado de pessoas durante a ditadura militar naquele país. Os crimes de que é acusado teriam sido cometidos entre 1976 e 1983, época em que Vallejos era militar na Escola de Mecânica da Armada Argentina (ESMA), conhecido centro clandestino de detenção, torturas, execuções e desaparecimentos durante a ditadura. O ministro relator, Gilmar Mendes, reiterou o entendimento firmado na Extradição 974, determinando a dupla tipicidade entre Argentina e Brasil com base no crime de sequestro.

De acordo com a jurisprudência do STF consolidada nestas três Extradições, e especialmente qualificada a partir do voto-vista do então ministro Cezar Peluso na Extradição 974, a morte da vítima só pode ser judicial e juridicamente atestada quando da apresentação de seus restos mortais ou mediante decisão judicial transitada em julgado dando conta da data e circunstâncias da morte. Caso contrário, não é possível afirmar-se juridicamente a morte de uma pessoa forçosamente desaparecida. Sendo assim, se a última notícia oficial que se tem a seu respeito é o sequestro desta pessoa, as autoridades responsáveis devem considerá-la como continuamente sequestrada.

Entretanto, como veremos a seguir, é notável que boa parte dos ministros da Suprema Corte que ratificava este entendimento a propósito das Extradições, entre eles o próprio Peluso, mais tarde, na $\mathrm{ADPF} 153$, considerariam que, entre outros impedimentos à persecução penal de agentes da repressão, estaria o fato de que todas as ações que diriam respeito a condutas praticadas durante a ditadura já estariam prescritas.

\subsection{2) As manifestações da AGU, da PGR e dos amici curiae na ADPF 153}

No curso da ADPF 153, além da OAB, manifestaram-se também a Advocacia Geral da União (AGU, que representou o governo brasileiro no processo), a Procuradoria Geral da República (PGR), a Câmara dos Deputados e o Senado Federal, por suas comissões jurídicas. Com exceção da $\mathrm{OAB}$ e de seus amici curiae ${ }^{14}$, os demais órgãos entenderam que o projeto de lei que deu lugar à anistia de 1979 seguiu corretamente o processo legislativo previsto na época. O Senado ainda foi adiante e pediu o reconhecimento da "impossibilidade jurídica do pedido" e a falta de "interesse de agir" da

\footnotetext{
${ }^{14}$ A Associação Juízes para a Democracia (AJD), por exemplo, propugnou, ao lado da OAB, pela ausência de conexão entre a prática de crimes por agentes repressores e os crimes políticos praticados pela oposição.
} 
ação em função de a Lei de Anistia já ter produzido e exaurido juridicamente seus efeitos no mesmo momento em que entrou em vigor. ${ }^{15}$

A AGU em seu parecer colecionou informações prestadas pela Secretaria Especial de Direitos Humanos, pela Sub-Chefia de Assuntos Jurídicos da Casa Civil, bem como pelos Ministérios das Relações Exteriores, da Justiça, da Defesa e a Consultoria Geral da União. Embora as informações prestadas pelo Ministério da Justiça e pela Sub-Chefia de Assuntos Jurídicos da Casa Civil tenham destoado das demais pelo fato de essencialmente concordarem com a ação ajuizada pela $\mathrm{OAB}$, a manifestação da $\mathrm{AGU}$ foi no sentido de traduzir a posição geral destes órgãos do governo para atacar o que considerava como vícios formais da ação e, no "mérito" $"$, para defender sua improcedência.

Para os advogados da União que subscreveram a manifestação no processo da ADPF 153 que representaria a posição da AGU (e por extensão do governo) a respeito do tema:

"O diploma legal surgiu da negociação havida entre a sociedade civil e o regime militar, que possibilitou, à época, a transição para o regime democrático. Dessa forma, assegurou-se, com a lei, que ambos os lados seriam beneficiados com a anistia, evitando-se, inclusive, qualquer espécie de revanchismo no novo governo" (AGU, 2009, p. 12).

A manifestação citou vastamente o parecer de Sepúlveda Pertence feito quando era conselheiro da OAB. Este parecer dos advogados da União, embora mais sucinto do que boa parte dos votos dos ministros do STF que viriam mais tarde, serviria de base para a argumentação - mais desenvolvida pelo ministro relator - a respeito do mérito. Segundo os advogados da União: "Pode-se afirmar, portanto, que a abrangência conferida, até então, à Lei $n^{0} 6.683 / 79$, decorre, inexoravelmente, do contexto em que fora promulgada" (AGU, 2009, p. 13).

Mesmo tendo citado o parecer de Sepúlveda Pertence de 1979, que tinha antes na crítica às limitações da Lei de Anistia seu principal escopo - especialmente no que diz respeito ao fato de não ter sido ela irrestrita nem suficientemente ampla ${ }^{17}$-, a manifestação da AGU afirmou em diferentes passagens que a anistia teria sido de fato

\footnotetext{
${ }^{15}$ No entendimento do Senado, reproduzido pela AGU, pela PGR e por ministros em seus votos mais tarde, uma vez que entra em vigor, na medida em que perdoa crimes, a anistia já produz e exaure seus efeitos. Revogá-la ou considerá-la inconstitucional, assim, seria o mesmo que fazer retroagir norma penal mais gravosa, o que é vedado pelo direito penal pátrio.

${ }^{16}$ No sentido jurídico da palavra, em oposição à discussão sobre as "preliminares" ou questões de ordem formal, muitas delas arguidas pela AGU, mas depois afastadas pelo STF, que seguiu o parecer da PGR a este respeito.

${ }^{17}$ Mais sobre o parecer de Sepúlveda Pertence para o Conselho Federal da OAB em 1979 pode ser lido no capítulo anterior.
} 
ampla, geral e irrestrita. Olvidou, neste ponto, o fato de que, apenas no que se refere ao direito penal, a Lei de Anistia excetuou de seus benefícios os praticantes de crimes políticos de sangue e os já condenados $\left(\S 2^{\circ}\right.$ do art. $\left.1^{\circ}\right)$.

Em seguida, de forma parecida com a manifestação do Senado, a AGU entendeu também que considerar a anistia penal aos agentes públicos que cometeram crimes em nome da repressão como não recebida pela Constituição de 1988 (ou como sequer inexistente na própria lei) equivaleria a proceder à retroatividade de lei penal mais severa, o que constituiria uma violação a direito fundamental. Isto porque a Lei de Anistia teria produzido e exaurido seus efeitos de isenção da responsabilidade penal destes agentes no instante mesmo em que foi publicada, encetando assim uma expectativa de que aqueles crimes haviam sido perdoados. Levantar este entendimento, assentado por anos pelos costumes e pela jurisprudência, na opinião dos advogados da União, seria o mesmo que fazer retroagir uma lei penal que tipificaria criminalmente no presente práticas realizadas no passado. O parecer retomou então vários autores da doutrina jurídica e da jurisprudência para dizer que anistia é apaziguamento e esquecimento.

Já o então procurador-geral da República, Roberto Gurgel, considerou também que a Lei de Anistia foi resultado de longo debate nacional, com a participação de vários setores da sociedade civil. De modo parecido com a AGU neste sentido, para ele, a anistia teria viabilizado a transição do autoritarismo para a democracia. $\mathrm{O}$ procurador teve $\mathrm{o}$ cuidado, porém, de destacar que preservar a imunidade penal bilateral não equivaleria a apagar o passado, que precisaria ainda ser melhor conhecido e discutido em nível social e político, mas não judicialmente. Sua manifestação afastou os problemas formais suscitados pela AGU, mas no mérito guardou posição bastante parecida. Dizia o parecer:

"A anistia, no Brasil, todos sabemos, resultou de um longo debate nacional, com a participação de diversos setores da sociedade civil, a fim de viabilizar a transição entre o regime autoritário militar e o regime democrático atual. A sociedade civil brasileira, para além de uma singela participação neste processo, articulou-se e marcou na história do país uma luta pela democracia e pela transição pacífica e harmônica, capaz de evitar maiores conflitos" (Roberto Gurgel apud Ministro Relator Eros Grau, 2010, p. 07).

Em seguida ao parecer da PGR, também o Centro pela Justiça e o Direito Internacional (CEJIL), a Associação Brasileira de Anistiados Políticos (ABAP) e a Associação Democrática e Nacionalista de Militares ingressaram como amici curiae, sendo que as duas primeiras apoiaram a petição da $\mathrm{OAB}$ e a segunda se colocou contra. 


\subsection{3) O voto do relator da ADPF 153}

Antes de entrarmos propriamente na reconstrução crítica dos argumentos dos ministros na ADPF 153, importa ressaltar uma discussão que o jurista Virgílio Afonso da Silva tem feito a respeito dos mecanismos de decisão e deliberação do STF. Veremos com mais detalhes outros aspectos da crítica do jurista mais adiante, mas por hora vale mencionar a observação que ele faz a respeito do fato de os ministros do STF se utilizarem do controle de constitucionalidade e outros julgamentos com grande repercussão na mídia para elaborar votos longos que marcariam suas carreiras. ${ }^{18} \mathrm{O}$ ex-ministro Cezar Peluso, por exemplo, no livro Ministro Magistrado - decisões de Cezar Peluso no Supremo Tribunal Federal (Peluso, 2013), publicou alguns dos votos que considerou mais importantes em sua carreira na Suprema Corte, entre eles o que fez a propósito da ADPF 153.

No voto que fez no julgamento de 2010 da ação em comento, o ministro relator Eros Grau se apoiou bastante na manifestação da PGR, pois também foi no sentido de afastar as exceções de preliminares e de declarar a improcedência da ação no mérito. Ele também citou longamente o parecer de Sepúlveda Pertence em 1979 e uma entrevista que o ex-conselheiro da $\mathrm{OAB}$ e ex-ministro do STF deu à revista Carta Maior sobre o assunto, na qual reiterava em geral os termos do parecer. ${ }^{19}$ Para Eros Grau (2010, p. 21), romper com a anistia pleiteada pelos movimentos dos anos 1970 seria inclusive prejudicar o acesso à verdade histórica. Segundo ele, os problemas do processo legislativo da Lei de Anistia afetam outras leis anteriores à Constituição Federal de 1988, mas nem por isso o Estado brasileiro pôde ou precisou considerá-las todas inconstitucionais. Isto porque seria inviável e também porque a maioria delas é materialmente (embora não formalmente) compatível com a Constituição em vigor:

Para ele: "A inicial ignora o momento talvez mais importante da luta pela redemocratização do país, o da batalha da anistia, autêntica batalha" (Ministro relator Eros

\footnotetext{
${ }^{18}$ Os ministros Eros Grau, Celso de Mello e Gilmar Mendes, por exemplo, fizeram votos de cerca de 40 a 50 páginas cada, pelo formato do arquivo de Inteiro Teor do julgamento fornecido pelo STF (vide nota 5), o qual utilizo como referência para as citações aqui. Entretanto, pelo formato A4 normalmente utilizado, os votos atingiriam um número bem maior de páginas. É o caso da versão digital do voto do ministro relator Eros Grau, que chega a 73 páginas. Esta versão também é disponibilizada pelo STF, sob o endereço eletrônico: http://www.stf.jus.br/arquivo/cms/noticianoticiastf/anexo/adpf153.pdf. Último acesso em 25 de março de 2015.

${ }^{19}$ Cf. entrevista "PNDH 3 é fiel à Constituição, diz Sepúlveda Pertence". Carta Maior, Porto Alegre, 18 jan. 2010. Caderno Política. Disponível em: http://cartamaior.com.br/?/Editoria/Politica/PNDH-3-e-fiel-aConstituicao-diz-Sepulveda-Pertence/4/15254. Último acesso: 25 de março de 2015.
} 
Grau, 2010, p. 25-26). ${ }^{20}$ A "formidável luta pela anistia" teria revelado notáveis do processo de redemocratização, como o senador Teotônio Vilela. Sem ponderar que a petição da $\mathrm{OAB}$ atacava apenas o $\S 1^{\circ}$ do art. $1^{\circ}$ da Lei, o relator frisou que revogar ou anular a anistia agora seria manchar a lembrança dos tantos que lutaram por ela, inclusive sob ameaças e atentados.

"Reduzir a nada essa luta, inclusive nas ruas, as passeatas reprimidas duramente pelas Polícias Militares, os comícios e atos públicos, reduzir a nada essa luta é tripudiar sobre os que, com desassombro e coragem, lutaram pela anistia, marco do fim do regime de exceção" (Min. Relator Eros Grau, 2010, p. 27).

Tecendo a narrativa histórica a respeito da conformação do projeto da lei às reivindicações dos movimentos pró anistia, assim como fizeram antes a AGU e a PGR, Eros Grau terminou por operar uma mistura entre a luta, de um lado, do Movimento Feminino por Anistia, do Comitê Brasileiro pela Anistia, da própria OAB e outros grupos, com os desígnios do projeto governista na época, de outro. Para sustentar sua argumentação, o relator citou, dentre outros, o testemunho do jurista Dalmo de Abreu Dallari a respeito das concessões que foi preciso fazer na época da abertura para que a anistia realmente saísse. É neste sentido que se referiu à anistia como um "acordo político" (Ministro Relator Eros Grau, 2010, p. 31).

Diz o voto também que a própria Lei de Anistia define seu conceito particular de crimes conexos, de forma diferente da usualmente utilizada no direito penal e de modo atrelado ao processo histórico da anistia. Em passagem que seria depois aproveitada pela Ementa $^{21}$ da decisão, o relator escreveu:

"Essa expressão, crimes conexos a crimes políticos, conota sentido a ser sindicado no momento histórico da sanção da lei. Sempre há de ter sido assim. A chamada Lei de anistia diz com uma conexão sui generis, própria ao momento histórico da transição para a democracia" (Min. relator Eros Grau, 2010, p. 35).

O ministro citou ainda a jurisprudência de tribunais brasileiros sobre várias anistias concedidas ao longo de mais de cem anos. Segundo seu entendimento, a jurisprudência do STF que trata da anistia de 1930 a considera estendida a crimes políticos e aos praticados pelas forças de segurança. Após longa retomada da jurisprudência do que seria um

\footnotetext{
${ }^{20}$ Neste ponto o relator citou também Marx em O 18 Brumário de Luís Bonaparte para dizer que os homens fazem sua própria história sob circunstâncias que não são de sua escolha.

${ }^{21}$ A Ementa é o documento que consolida propriamente o entendimento e a decisão institucional da Corte sobre o assunto em discussão.
} 
costume de se conceder anistias "bilaterais" no país e fazendo um paralelo entre a anistia de 1979 e as demais, o relator arriscou uma relação entre esta história de concessões bilaterais de anistia após momentos de tensão política no país e um certo aspecto associado a uma sociabilidade particular do povo brasileiro: "Há momentos históricos em que o caráter de um povo se manifesta com plena nitidez. Talvez o nosso, cordial, se desnude na sucessão das frequentes anistias concedidas entre nós" (Min. relator Eros Grau, 2010, p. 43).

Embora sem praticamente se referir à jurisprudência ou à legislação internacional a respeito do tema, a fim de explicar melhor seu entendimento sobrea Lei de Anistia, Eros Grau tentou traduzir o conceito de Massnahmegesetze, do direito alemão, para o caso da anistia brasileira. Segundo ele, o conceito se refere a "leis-medida [que] disciplinam diretamente determinados interesses, mostrando-se imediatas e concretas" (Min. relator Eros Grau, 2010, p. 44). E, na página seguinte: "Pois o que se impõe deixarmos bem vincado é a inarredável necessidade de, no caso de lei-medida, interpretar-se, em conjunto com o seu texto, a realidade no e do momento histórico no qual ela foi editada, não a realidade atual".

A interpretação histórica da anistia e da transição tem assim absoluta centralidade para o propósito de exegese da lei na visão do ministro. É esta interpretação que poderá dar ensejo às considerações jurídicas sobre a extensão e os efeitos da lei. Em outro trecho também aproveitado na Ementa da decisão, Eros Grau repisou:

“É a realidade histórico-social da migração da ditadura para a democracia política, da transição conciliada de 1979 que há de ser ponderada para que possamos discernir o significado da expressão crimes conexos na Lei n. 6.683. [...] Exatamente aquela na qual, como afirma inicial, 'se procurou' [sic] estender a anistia criminal de natureza política aos agentes do Estado encarregados da repressão" (Min. relator Eros Grau, 2010, p. 49-50).

As leis-medidas, dirá ele um pouco adiante, não são regras dotadas de abstração e generalidade:

"Há quem se oponha ao fato de a migração da ditadura para a democracia política ter sido uma transição conciliada, suave em razão de certos compromissos. Isso porque foram todos absolvidos, uns absolvendo-se a si mesmos. Ocorre que os subversivos a obtiveram, a anistia, à custa dessa amplitude. Era ceder e sobreviver ou não ceder e continuar a viver em angústia (em alguns casos, nem mesmo viver)" (Ibid. idem, p. 57). 
No que se refere às breves passagens mais atinentes aos argumentos jurídicos, Eros Grau lembrou que a Lei de Anistia precede a Convenção da ONU contra a Tortura e Outros Tratamentos ou Penas Cruéis, Desumanos ou Degradantes e sua internalização no direito brasileiro. Com relação ao inciso XLIII do artigo $5^{\circ}$ da Constituição Federal, que trata da imprescritibilidade e da insuscetibilidade de anistia a crimes como tortura e outros hediondos, Eros Grau considerou que não há que se falar em não recepção, pela Constituição, do parágrafo $1^{\circ}$ do art. $1^{\circ}$ da Lei de Anistia, pelo fato de ter a lei já produzido e exaurido todos seus efeitos. Nesta passagem, referiu-se à nota introdutória de Nilo Batista à obra de Antonio Martins, Dimitri Dimoulis e Lauro Joppert Swensson Junior (2010), que será comentada com mais detalhe adiante neste capítulo.

Em posição estranha ao ativismo da Corte em matéria de controle de constitucionalidade - em que muitas vezes o STF tem não só declarado inconstitucionalidades de leis ou trechos de leis, mas também suprimido omissões legislativas -, Eros Grau também sustentou em seu voto que "nem mesmo para reparar flagrantes iniquidades o Supremo pode avançar sobre a competência constitucional do Legislativo" (Min. relator Eros Grau, 2010, p. 59).

Ao final do voto, o ministro fez breve referência às decisões dos Tribunais na Argentina e no Uruguai que reconheceram a inconstitucionalidade das anistias para seus militares. No caso brasileiro, entretanto, a Emenda Constitucional (EC) n. 26/1985 teria alçado a anistia de 1979 a status constitucional. Esta Emenda expandia os contornos da anistia ao mesmo tempo em que convocava a Assembleia Nacional Constituinte. Para ele, a EC 26/1985 repunha a anistia de 1979 em período já de verdadeira transição democrática, sem os constrangimentos que cercavam as discussões sobre o projeto do governo no final da década de 1970. A respeito da referida Emenda, Eros Grau recorreu a Tércio Sampaio Ferraz Júnior, para quem a EC 26/1985 assumiria caráter constitutivo do novo sistema normativo que iria se instaurar a partir da Constituição de 1988. Para o jurista, esta Emenda seria uma "norma-origem" (Ferraz Júnior apud Min. relator Eros Grau, 2010, p. 68).

A anistia é assim elevada à condição de pacto fundante do novo regime democrático, uma espécie de norma hipotética fundamental kelseniana (que dá ensejo à legitimidade da própria Constituição e ao Estado entendido como ordenamento jurídico), mas com a diferença de não ser hipotética, senão concreta. A norma-origem fundamental da Constituição de 1988 e do Estado de Direito fundado a partir daí seria justamente a anistia de 1979 reiterada e expandida pela EC 26/1985: “A Emenda Constitucional n. 
26/85 inaugura a nova ordem constitucional. [...] Consubstancia, nesse sentido, a revolução branca que a esta confere legitimidade" (Min. relator Eros Grau, 2010, p. 69). É desta forma que o rechaço da bilateralidade da lei poderia repercutir negativamente na estabilidade social (Cf. ibid. idem, p. 71). ${ }^{22}$

\subsection{4) Os votos divergentes}

O ministro Ricardo Lewandowski apresentou o primeiro voto divergente entendendo que, caso a caso, cada magistrado teria de decidir, pelos critérios "da preponderância e da atrocidade dos meios" (Lewandowski, 2010, p. 130), se seria a hipótese de se estar diante de um crime político ou de um crime comum, este não coberto pela Lei de Anistia. Diferentemente de seus colegas, Lewandowski recuperou o julgado do STF na Extradição 974, na qual seu voto divergente conseguira reverter o resultado apontado pelo então relator Marco Aurélio Mello.

Lewandowski também tentou desestabilizar a visão histórica a respeito do "acordo político" em torno da anistia. Para o ministro, seria preciso superar a ideia de uma "vontade do legislador" em direção à noção de "vontade da lei” mediante a utilização de critérios hermenêuticos mais objetivos (Lewandowski, 2010, p. 109-110). Do ponto de vista da exegese técnica, então, o ministro procurou vislumbrar o sentido que o termo “conexão" poderia assumir na Lei de Anistia. Para tanto, citou jurisprudência do próprio STF para mostrar que crimes conexos aos políticos são crimes comuns praticados para a viabilização de atividade política (criminosa ou não) dos grupos de resistência (Cf. Lewandowski, 2010, p. 115). Neste sentido, os crimes conexos, conforme sua conceituação usual a respeito da chamada "conexão material",23, seriam os praticados pelos mesmos agentes dos crimes políticos. Para se verificar, então, se haveria ou não a possibilidade de se anistiar agentes da repressão seria preciso ver se eles praticaram ou não crimes políticos.

\footnotetext{
${ }^{22}$ No debate do plenário logo após a apresentação do voto do relator, Gilmar Mendes, já antecipando sua concordância com o voto do relator também no que diz respeito à importância fundacional da anistia para a novo regime democrático, sustentou que a Constituição não deveria iluminar a interpretação da Lei de Anistia porque esta faria parte da própria Constituição (Cf. Gilmar Mendes, 2010, p. 73).

${ }^{23} \mathrm{Em}$ oposição à "conexão formal", que pode ensejar o julgamento em uma mesma lide de práticas criminosas de autores ou grupos diferentes ou rivais, mas apenas por uma questão de unidade de competência (uma questão formal). A "conexão material", propriamente, refere-se a uma ligação real entre crimes diferentes cometidos pelo mesmo autor ou pelos mesmos autores, como, por exemplo, a invasão de domicílio e o furto de objetos neste mesmo domicílio.
} 
Lewandowski julgou “desnecessário” adentrar em discussão a respeito dos crimes de lesa-humanidade, uma vez que a maioria das condutas criminosas já eram tipificadas na época em que ocorreram (Lewandowski, 2010, p. 115-117). A tortura, por exemplo, poderia ser definida pelo concurso entre lesões corporais, maus-tratos, abuso de autoridade, dentre outros.

O ministro passou então a longa exposição com base na jurisprudência da Corte para definir e diferenciar "crimes políticos típicos", "crimes políticos relativos" e "crimes comuns" (Lewandowski, 2010, p. 118-127). O voto deixou algumas dúvidas a respeito do fato de, se no entendimento do ministro, também poderia ou não haver a ponderação sobre crimes comuns praticados por militantes da luta armada, e portanto passíveis de persecução penal. E, inversamente, se crimes praticados por agentes da repressão seriam desde logo crimes comuns ou se poderiam ser também considerados, dependendo do caso, como crimes políticos, e portanto protegidos pela anistia. Estas dúvidas ficaram particularmente salientes quando o ministro indicou que seria preciso aos magistrados avaliar "caso a caso" se seria a hipótese de um ou outro tipo de crime.

Depois de Lewandowski votou Ayres Britto, também de forma divergente, mas diferentemente do voto anterior, entendeu como fora do alcance da anistia os crimes hediondos e equiparados, previstos no inciso XLIII do artigo $5^{\circ}$ da Constituição de 1988. Ao fim e ao cabo, Ayres Britto seria o único a realmente dispor de uma resposta no sentido do pedido original da $\mathrm{OAB}$, de que o STF ou produzisse interpretação da anistia conforme a Constituição de 1988 ou então que considerasse o não recebimento, pela Constituição, do caráter bilateral da anistia, que poderia ser depurado do $\S 1^{\circ}$ do artigo $1^{\circ}$ da lei.

Ayres Britto também criticou o voto do relator com relação ao que seria uma ênfase demasiada nas tratativas da Lei de Anistia e no "método histórico", que no seu entendimento deveria ser subsidiário à exegese jurídica, não central. Ao sustentar que os crimes hediondos praticados por agentes da repressão durante a ditadura não teriam sido recebidos pelo princípio constitucional que veda a anistia destes crimes, o ministro sustentou que a prática dos piores crimes naquela época teria ocorrido à revelia do próprio comando autoritário.

"Quero fazer uma distinção. As Forças Armadas tomaram o poder político no Brasil a 31 de março de 1964, mas o fizeram às claras, abertamente, à luz do dia, dizendo para o que vieram. [...] instituíram uma ordem jurídica autoritária ou não democrática. Mas ainda assim uma ordem jurídica. Sabia-se com previedade quais as regras do jogo 
coletivo. Essas pessoas de quem estamos a tratar - torturadores et caterva - desobedeceram não só a legalidade democrática de 1946, como a própria legalidade autoritária do regime militar" (Ayres Britto, 2010, p. 138-39).

Descuidava-se, assim, de conhecimento histórico razoavelmente consensual pelas pesquisas acadêmicas e mesmo por publicações do governo brasileiro, especialmente Direito à memória e à verdade ${ }^{24}$, a respeito da coordenação, pelo próprio governo militar e pela cúpula das forças de segurança, da prática de crimes associados ao empreendimento repressivo. Especialmente a tortura era notadamente realizada mediante determinações do alto escalão militar, ainda que à revelia da legislação da época. É possível que o ministro tenha se valido de tal argumentação para escapar à alegação de que, tendo sido resultado de uma ação organizada pelos órgãos de segurança e pelo governo, tais crimes poderiam ser considerados como crimes políticos, e portanto abrangidos pelos benefícios da lei qualquer que fosse a concepção sobre os "crimes conexos".

O jurista Lauro Joppert Swensson Júnior, por exemplo, bastante citado pelos ministros que deram improcedência ao pedido da OAB (sobretudo o relator Eros Grau e o ministro Gilmar Mendes), é desta opinião: "Preservar o Estado autoritário é também agir motivado politicamente" (Swensson Júnior apud Gilmar Mendes, 2010, p. 147). Entretanto, esta dificuldade poderia ter sido superada no voto de Ayres Britto sem a distorção de um dado histórico bastante importante para o entendimento da trajetória política recente do país, caso o ministro houvesse se valido da normativa e da jurisprudência das Cortes internacionais a respeito da matéria. Mas Ayres Britto, assim como a maioria de seus colegas, citou apenas en passant a legislação internacional que tipifica os crimes contra a humanidade.

O ministro também contestou a ideia de que a EC 26/1985 seria uma norma constituinte: para ele, ela pode tê-lo sido apenas provisoriamente.

\subsection{5) Os votos que acompanharam o relator}

A Ministra Carmen Lúcia, que votou em seguida ao relator, começou em sua manifestação por destacar bastante a importância do "direito à verdade" e do "direito à história” (Carmen Lúcia, 2010, p. 81). Ela citou também amplamente o parecer de

\footnotetext{
${ }^{24}$ Já publicado na época e comentado mais detidamente no capítulo anterior. A Comissão Nacional da Verdade viria a ser instalada apenas em 2012.
} 
Sepúlveda Pertence de 1979, que teria se configurado numa espécie de representante da voz dos movimentos a respeito do projeto governista. Embora a ministra não tenha acompanhado o entendimento segundo o qual a anistia teria sido constitucionalizada pela EC 26/1985, destacou também a importância da avaliação do contexto histórico e da “intenção legislativa” para a interpretação da lei (Carmen Lúcia, 2010, p. 90). Para ela, o fato de a lei vigorar por mais de 30 anos tornaria uma mudança em seus efeitos uma ofensa à segurança jurídica.

Em sua concepção, "a análise do elemento histórico específico da lei conduz à conclusão oposta [à apresentada pela $\mathrm{OAB}$ ], quer o juiz goste ou não do panorama a ser visto". E mais adiante: "Nem sempre as leis são justas, embora sejam criadas para que o sejam" (Carmen Lúcia, 2010, p. 91-92). A ministra fez assim nítida distinção entre o direito e a lei, de um lado, e critérios mais abrangentes de justiça, de outro. De acordo com este raciocínio, nem sempre uma lei, ainda que válida, será justa, mas mesmo assim deverá prevalecer, se pelo menos faz sentido para um certo objetivo social. Em outras palavras, mais do que encetar uma separação entre o justo e o direito, a ministra tentou aproximar a noção de justiça a um desígnio de bem estar social.

Numa confusão entre os conceitos, a ministra considerou buscar "o que seja necessário para se chegar ao justo, em termos de paz social” (Carmen Lúcia, 2010, p. 92). E prosseguiu: "os motivos que levaram à elaboração daquela lei [...] foram a reconciliação e a pacificação nacional, num momento em que era necessário ultrapassar o regime ditatorial [...]" (ibid. idem). As considerações da ministra sobre como teria se dado a transição são rápidas, mas a passagem sobre a importância da questão do "contexto" para a interpretação da lei ganha várias considerações teóricas, referências bibliográficas e investidas no sentido da elaboração de novos conceitos a partir do direito comparado (como no caso das "leis-medida").

Ellen Gracie manifestou-se em seguida fazendo o voto mais curto. Ela retomou a acepção grega de "anistia" para dizer que é esquecimento. Também destacou o "pacto conciliatório" que a Lei 6.683/1979 teria ensejado para a transição democrática e que, em seu entendimento, toda transição pacífica pressupõe "concessões recíprocas": "Por incômodo que seja reconhecê-lo hoje, quando vivemos outro momento histórico, a anistia, inclusive daqueles que cometeram crimes nos porões da ditadura, foi o preço que a sociedade brasileira pagou para acelerar o processo pacífico de redemocratização" (Ellen Gracie, 2010, p. 153). 
Já Marco Aurélio Mello, em mais uma demonstração de profundo desconhecimento histórico ou puro cinismo, em um dos breves momentos de debate, asseverou acreditar que, depois de publicada a Lei de Anistia, não tenham mais sido praticados “desvios de conduta apanhados por essa Lei” (Marco Aurélio Mello, 2010, p. 154). O ministro também se mostrou ressentido com os colegas que não acompanharam seu voto de relator na Extradição 974, cuja matéria, já indicava o ministro naquela época, era coeva ao assunto do julgamento da ADPF 153.

O ministro Celso de Mello elaborou o voto mais técnico dentre os que consideraram a ação da OAB improcedente. Em sua manifestação, começou tecendo longa reprovação do "regime de exceção" e dos crimes bárbaros associados à repressão política. Celso de Mello também mencionou a "definição autêntica" do conceito de crimes conexos no bojo da Lei de Anistia, que, segundo ele, teria possibilitado "a construção do necessário consenso" para a transição (Celso de Mello, 2010, p. 174).

O ministro se reportou também à importância da análise dos debates parlamentares na exegese da lei. Neste sentido, citou preferencialmente, além do parecer de Sepúlveda Pertence, o discurso do então congressista do MDB Paulo Brossard, que assim como Pertence identificava o caráter bilateral na Lei de Anistia. ${ }^{25}$ Celso de Mello foi certamente o ministro que na ocasião mais discutiu princípios internacionais dos direitos humanos e dispostos na Constituição Federal de 1988.

Aliás, foi o único a realizar um "controle de convencionalidade" da jurisprudência da CrIDH e da Convenção Americana de Direitos Humanos (CADH) em face da matéria discutida na ADPF $153 .{ }^{26}$ A este respeito, Celso de Mello ponderou que a anistia brasileira não poderia ser considerada (como outras anistias ocorridas em países latino-americanos antes da transição do autoritarismo para a democracia) como uma autoanistia, justamente em função de seu caráter bilateral: ela não anistiou apenas agentes públicos associados à repressão (como em outros países latino-americanos), mas também opositores do regime. Neste mesmo ponto, o ministro também investiu numa mistura entre as demandas sociais por anistia e o teor da lei que acabou sendo publicada:

"Como anteriormente ressaltado, não se registrou, no caso brasileiro, uma auto-concedida anistia, pois foram completamente diversas as circunstâncias históricas e políticas que presidiram, no Brasil, com o concurso efetivo e a participação ativa da sociedade civil e da oposição militante, a discussão, a elaboração e a edição da Lei de Anistia, em

\footnotetext{
${ }^{25}$ E assim como Pertence também viria a ser ministro do STF, mas entre 1989 e 1994.

${ }^{26} \mathrm{O}$ controle de convencionalidade é análogo ao controle de constitucionalidade de leis, mas avalia, na verdade, a compatibilidade entre uma lei doméstica e tratados internacionais.
} 
contexto inteiramente distinto daquele vigente na Argentina, no Chile e no Uruguai, dentre outros regimes ditatoriais" (Celso de Mello, 2010, p. 185).

A anistia e a transição brasileiras seriam assim, pelo menos em contexto latinoamericano, absolutamente sui generis.

Celso de Mello frisou também que a Lei 6.683/1979 precedeu tratados e convenções internacionais contra a tortura e sua internalização ao ordenamento jurídico brasileiro. A Lei de Anistia, continuou, produziu e exauriu seus efeitos no momento mesmo em que foi publicada, de modo que revogá-la ou considerá-la como inconstitucional depois de décadas seria o mesmo que fazer retroagir lei penal mais gravosa, o que é vedado pelo princípio da anterioridade. ${ }^{27}$ Já a Convenção sobre a Imprescritibilidade dos Crimes de Guerra e dos Crimes contra a Humanidade não havia sido assinada até então pelo Brasil. O Estatuto de Roma, que, entre outras coisas, define o conceito de crimes contra a humanidade e criou o Tribunal Penal Internacional, embora assinado pelo Brasil, ainda não tinha passado pelo processo de internalização no direito pátrio, não sendo, portanto, aplicável, na concepção do ministro (Cf. Celso de Mello, 2010, p. 194 e 195). Ao final, ressaltou a importância de se recuperar a memória histórica sobre os acontecimentos relacionados à repressão durante a ditadura.

O ministro Cézar Peluso, assim como Ellen Gracie, também fez um voto relativamente curto. Para ele, qualquer interpretação sobre anistias tem que ser "generosa" (Peluso, 2010, p. 208). Segundo seu entendimento, o $\S 1^{\circ}$ do artigo $1^{\circ}$ da Lei 6.683/1979 claramente estendeu a isenção de responsabilidade penal aos agentes do regime autoritário, embora não o tenha feito explicitamente. Seriam prova disso os debates legislativos da época, bem como a reação dos movimentos que reprovaram também este aspecto da lei. ${ }^{28}$

Seria o caso, portanto, não de rever uma interpretação da lei, mas apenas de ponderar se este seu aspecto teria sido ou não recebido pela Constituição de 1988. Em sua opinião sim, a bilateralidade teria sido recebida, fundamentalmente em função da "igualdade" entre opositores e agentes da repressão que a previsão ensejava. Mas o ministro esqueceu-se de que os opositores anistiados haviam todos sofrido algum tipo de

\footnotetext{
${ }^{27}$ A este respeito, assim como outros colegas, citou a obra Justiça de Transição, organizada por Dimitri Dimoulis, Lauro Joppert Swensson Júnior e Antonio Martins, para dizer que a legislação internacional e o dispositivo constitucional que proíbem a anistia a crimes contra a humanidade, porque posteriores à Lei de Anistia, não podem desfazer seus efeitos.

${ }^{28}$ A reprovação dos movimentos por anistia sobre o caráter bilateral da lei seria uma comprovação de que este caráter sempre constou da norma.
} 
punição, legal ou ilegal - da cassação de direitos, exoneração, exílio, até se chegar à prisão ilegal, tortura, morte e desaparecimento -, ao passo que os agentes da repressão não. Também negligenciou o voto alentado que ele mesmo fizera na Extradição 974, na qual reconheceu que os desaparecidos políticos não poderiam ser considerados como mortos sem sentença neste sentido e que, portanto, o crime de sequestro a que foram submetidos deveria ser reputado como ainda em curso. À revelia das consequências de seu próprio entendimento na Extradição 974, Peluso considerou na ADPF 153 que a ação da OAB não teria repercussão de ordem prática alguma, pois "todas as ações penais estão prescritas" (Peluso, 2010, p. 211). Antes de terminar seu voto, o ministro também teceu comentários sobre o impedimento de se fazer retroagir leis penais mais gravosas e finalizou com considerações sobre a importância histórica do "pacto nacional" da anistia para a transição:

"Se é verdade que cada povo acerta contas com o passado de acordo com a sua cultura, com os seus sentimentos, com a sua índole e com a sua história, o Brasil fez uma opção pelo caminho da concórdia. [...] Só uma sociedade superior, qualificada pela consciência dos mais elevados sentimentos de humanidade, é capaz de perdoar, porque só uma sociedade que, por ter grandeza, é maior do que seus inimigos, é capaz de sobreviver" (Peluso, 2010, p. 209).

Por último votou Gilmar Mendes, que foi um dos que mais se engajou no sentido de mostrar a importância da anistia e da conciliação que ela proporcionaria para preparar o terreno para a transição. Ao lado do relator Eros Grau, Gilmar Mendes se esforçou por defender não só a constitucionalidade mas o status de norma constitucional da Lei de Anistia via EC 26/1985. Mais do que isso, o ministro faria desta argumentação o objetivo central de seu voto: “[...] a anistia ampla e geral representa o resultado de um compromisso constitucional que tornou possível a própria fundação e a construção da ordem constitucional de 1998" (Gilmar Mendes, 2010, p. 235).

O ministro é mais um que citou longamente o parecer de Sepúlveda Pertence em 1979 e sua entrevista à Carta Maior antes do julgamento do STF em 2010. Na opinião de Gilmar Mendes (2010, p. 249), o ex-ministro do STF teria sido uma "testemunha privilegiada" da Lei de Anistia e de seu sentido último. O voto citou longamente também o parecer do Instituto dos Advogados do Brasil feito na época da anistia e trechos do discurso do então senador Paulo Brossard, igualmente citado por Celso de Mello. Para Gilmar Mendes, o Brasil seria devedor dos que buscaram, como o senador Brossard, pela via pacífica e institucional, lutar pela democracia. 
Em sua visão, a EC 26/1985 teria alçado a anistia a pressuposto de possibilidade da nova ordem constitucional: "a EC n. ${ }^{0}$ 26, de 1985, que convocou a Assembleia Nacional Constituinte e deu início ao processo constituinte, incorporou a anistia, expressamente em seu art. $4^{\circ}$, como um dos pressupostos de possibilidade da construção da nova ordem constitucional" (Gilmar Mendes, 2010, p. 252-253).

Imbuído desta ideia, o ministro fez longa incursão teórica a partir do direito alemão e de conceitos trazidos de Carl Schmitt para tentar argumentar que a EC 26/1985 seria uma espécie de norma análoga à chamada "revisão total" da Constituição. Este tipo de norma, que regula o processo de substituição de uma Constituição, deveria, segundo ele, assim como as cláusulas pétreas, ser protegida pelo princípio da imutabilidade. Isto porque as regras atinentes ao emendamento constitucional ou à própria substituição da Constituição, se pudessem ser alteradas, poderiam ensejar a possibilidade de emendamento das próprias cláusulas pétreas (direitos fundamentais).

Por uma questão de lógica, então, para que os direitos fundamentais sempre possam gozar da imutabilidade, as regras de emendamento e revisão (substituição) total da constituição precisam ser consideradas elas mesmo intangíveis. Escreveu o ministro: “A EC 26/85 muito se aproxima de um modelo de revisão total instaurado pela própria ordem constitucional, sem maiores rupturas do ponto de vista histórico-político". E mais adiante: "Parece certo que estamos, dessa forma, diante de uma hipótese na qual estão em jogo os próprios fundamentos de nossa ordem constitucional" (Gilmar Mendes, 2010, p. 264).

$\mathrm{Na}$ Ementa do acórdão do STF, a ação da OAB foi julgada improcedente nos termos do voto do relator.

\subsection{6) A ADPF 153 e a "ideologia secundária"}

O livro Justiça de Transição, citado por muitos dos ministros do STF no julgamento da ADPF 153 e já mencionado acima, pode ser considerado, ao lado dos próprios votos que declararam a ação da $\mathrm{OAB}$ como improcedente, como uma espécie de "ideologia secundária" em defesa das noções tradicionais das categorias "anistia", “conciliação", "transição", entre outras, no processo justransicional brasileiro. O sociólogo Debrun (1983) considerava como "ideologia primária" uma fundamentação de categorias que, por ser hegemônica e pouco contestada, não precisa ser uma fundamentação muito desenvolvida. Já a “ideologia secundária” é suscitada quando as noções tradicionais de 
certas categorias passam a ser seriamente desafiadas; neste contexto, uma fundamentação mais densa sobre os fundamentos das categorias tradicionais é muitas vezes elaborada.

Desde 2007, pelo menos, com a publicação de Direito à verdade e à memória pela CEMDP e com os novos projetos no terreno da verdade e da memória encampados pela Comissão de Anistia sob liderança de Paulo Abrão, as concepções tradicionalmente fundadas em torno da Lei de Anistia, passando por seus desenvolvimentos posteriores na EC 26/1985, no ADCT e mesmo na Lei dos Desaparecidos, passaram a ser colocadas em xeque, não só por ex-perseguidos e familiares, mas também por órgãos do Estado.

Do ponto de vista do direito, a primeira expressão importante desta mudança foi incorporada na ação promovida em 2008 pela OAB, cujo Conselho Federal se aproximou das perspectivas teóricas e empíricas de membros da Comissão de Anistia. Antes disso, enquanto as concepções tradicionais não eram seriamente desafiadas a partir de instituições do próprio Estado brasileiro, as formulações em sua defesa podiam ser mais breves e menos desenvolvidas tecnicamente, como o foram a mensagem que acompanhava o projeto de anistia encaminhado pelo governo Figueiredo ao Congresso ou as várias declarações de chefes de Estado e de governo desde então. ${ }^{29}$ Numa situação diferente hoje, justamente quando aquelas concepções tradicionais são mais atacadas, elas ganham também tentativas mais longas e concatenadas de justificação.

A obra Justiça de Transição, organizada por Dimitri Dimoulis, Lauro Joppert Swensson Júnior e Antonio Martins (2010) constitui, do ponto de vista da doutrina jurídica atualizada, a elaboração mais consistente em defesa da validade da Lei de Anistia e pode ser considerada, neste sentido, ao lado dos votos dos ministros do STF que julgaram a ADPF 153 improcedente em 2010, como uma ideologia secundária sobre as concepções tradicionais daquelas categorias. Por isso, importa fazer aqui uma breve incursão a respeito dos principais argumentos nela aduzidos. Segundo o jurista e professor Nilo Batista, por exemplo, responsável pela alentada introdução da obra, os argumentos de Swensson Júnior seriam os mais "implacáveis" no sentido da defesa da validade da anistia. Em trecho incorporado à argumentação de Celso de Mello em seu voto na ADPF 153, lê-se:

“[...] Swensson Júnior tem a coragem de formular a pergunta politicamente incorreta mas juridicamente indispensável: os agentes do subsistema penal DOPS-DOI/CODI atuaram 'por razões pessoais' (sadismo, desafetos etc) ou 'por razões políticas - por exemplo, para salvaguardar o país dos comunistas'? [...] Mas o argumento da anistia,

\footnotetext{
${ }^{29}$ Esta mensagem e as declarações foram comentadas no capítulo 2.
} 
tanto quanto o da evidentíssima prescrição, sucumbiria perante a segunda linha argumentativa [dos que contestam a bilateralidade]: 'as ações dos agentes da repressão política estatal são crimes contra a humanidade, e por isso são imprescritíveis e não podem ser anistiados'. A refutação de Swensson Júnior é implacável: em primeiro lugar, instrumentos normativos internacionais só adquirem força vinculante após o processo constitucional de internalização, e o Brasil não subscreveu a 'Convenção sobre Imprescritibilidade dos Crimes de Guerra e dos Crimes contra a Humanidade de 1968 nem qualquer outro documento que contivesse cláusula similar'; em segundo lugar, 'o costume internacional não pode ser fonte de direito penal', sem violação de uma função básica do princípio da legalidade; e, em terceiro lugar, conjurando o fantasma da condenação pela Corte Interamericana, a exemplo do precedente 'Arellano x Chile', a autoridade de seus arestos foi por nós reconhecida plenamente em 2002 (Dec. N. 4.463, de 8 de novembro de 2002) porém apenas 'para fatos posteriores a 10 de dezembro de 1998"' (Nilo Batista apud Celso de Mello, 2010, p. 193194).

Em seu primeiro registro de defesa da bilateralidade da Lei de Anistia, esta linha de argumentação utiliza-se justamente do aspecto da sistematicidade e organicidade dos crimes da ditadura para dizê-los "políticos" e por isso anistiados. De certa forma, configura o mesmo que dizer que os crimes estariam anistiados justamente por serem crimes contra a humanidade, que são caracterizados pelo alto grau de atrocidade e pela sistematicidade nas violações cometidas. Neste sentido, para os que acolhem esta argumentação, a estrutura autoritária e criminosa instaurada pelo governo militar e revelada em maior profundidade, por exemplo, a partir dos trabalhos da Comissão Nacional da Verdade (que seria instalada dois anos depois do julgamento do STF e da publicação da obra em comento) terminaria por fazer água nesta apologia.

Enquanto que, como vimos no capítulo 1, em direção oposta, o desenvolvimento do direito internacional dos direitos humanos tem chegado a um consenso normativo e jurisprudencial em torno da não aplicabilidade de institutos como a prescrição, a anistia e mesmo a irretroatividade da lei penal mais gravosa em função da ofensa que a prática destes crimes constitui não só contra suas vítimas diretas, mas contra toda a humanidade. Outro motivo para estes contornos do conceito de crimes contra a humanidade é o fato de que é razoável supor-se, enquanto perdura o autoritarismo ou a guerra (e mesmo algum tempo depois), que as vítimas têm muita dificuldade (se não um completo impedimento) de conseguir acesso a um sistema Judiciário eficientemente engajado na defesa dos direitos humanos. Daí porque a imprescritibilidade, a insuscetibilidade de anistia e a necessidade, por vezes, de se aplicar retroativamente normas penais mais gravosas. 
Da mesma forma, como passaram a reconhecer o Ministério Público a partir de 2011 e a Procuradoria Geral da República a partir da posse de Rodrigo Janot em outubro de $2013^{30}$, o direito costumeiro internacional também deve ser considerado como norma cogente em matéria de direitos humanos por motivos semelhantes, isto é, pelo fato de ser igualmente razoável supor-se que regimes autoritários não internalizem normas internacionais relativas aos direitos humanos. Nestes casos, as vítimas só podem ter seus direitos fundamentais reconhecidos se o costume internacional em matéria de direitos humanos for reconhecido (posteriormente ou por tribunais internacionais) como fonte de jus cogens, e por isso de aplicação obrigatória.

3.2) O julgamento da Corte Interamericana, as ações penais promovidas pelo MPF e outras possibilidades do avanço do mecanismo "justiça"

\subsection{1) A Corte Interamericana e o caso Guerrilha do Araguaia}

O Brasil já foi condenado quatro vezes pela $\mathrm{CrIDH}$, no caso da morte por maustratos do paciente com distúrbio mental Daniel Ximenes Lopes; com relação ao grampo ilegal para espionagem do MST (Movimento dos Trabalhadores Rurais Sem Terra); no que se refere ao assassinato do trabalhador rural Sétimo Garibaldi; e finalmente no chamado Caso Araguaia, quando o Estado brasileiro foi condenado, entre outros itens, a processar criminalmente e a julgar os autores das graves violações de direitos humanos cometidas por agentes públicos na repressão à guerrilha do $\mathrm{PCdoB}(1964-1985){ }^{31}$

Desde o início da década de 1980, os familiares dos desaparecidos no Araguaia entre 1972 e 1976 têm percorrido a região à procura de informações e dos restos mortais dos militantes. Em 1982, ajuizaram uma ação contra a União em que pleiteavam do juízo a determinação de que o poder público prestasse esclarecimentos sobre as circunstâncias da morte e a localização dos restos mortais de seus entes. Diante da morosidade injustificável de uma decisão definitiva para a ação, a Comissão de Familiares de Mortos e Desaparecidos Políticos, o grupo Tortura Nunca Mais do Rio de Janeiro e o Centro pela Justiça e o Direito Internacional (CEJIL) protocolaram, já em 1995, uma demanda perante

\footnotetext{
${ }^{30}$ Veremos isso com mais detalhes adiante.

31 Cf. a sentença da Corte Interamericana de Direitos Humanos (2010). Disponível em: http://www.corteidh.or.cr/docs/casos/articulos/seriec_219_por.pdf. Último acesso em 26 de março de 2015.
} 
a Comissão Interamericana de Direitos Humanos em que denunciavam a violação do direito à verdade dos familiares e da sociedade brasileira em função de o Estado não ter empreendido esforços para o esclarecimento circunstanciado acerca das violações praticadas contra os guerrilheiros e do paradeiro dos desaparecidos. Mais de 10 anos depois, em 2008, a Comissão Interamericana publicaria um conjunto de recomendações que em boa parte não seriam cumpridas pelo Estado brasileiro, motivando a submissão do caso à Corte Interamericana em março de 2009.

No ano seguinte, meses após a decisão do STF na ADPF 153, a CrIDH, em sua sentença sobre o caso Araguaia, responsabilizou internacionalmente o Brasil pelo desaparecimento de cerca de 70 pessoas, entre os anos de 1972 e 1976, vinculados à guerrilha, que era composta por militantes do PCdoB e tinha por objetivo derrotar a ditadura militar no Brasil e realizar uma revolução socialista partindo do campo. Depois de algumas primeiras expedições malsucedidas do Exército brasileiro, o grupo foi aniquilado entre 1973 e 1975. Na época, as ações militares foram negadas e a grande maioria das notícias a respeito era barrada pela censura.

Seguindo sua jurisprudência em outros casos, como indicado no capítulo 1, a sentença da Corte Interamericana determinou a responsabilidade do Estado brasileiro pelo desaparecimento forçado das vítimas e reprovou a situação de impunidade e a falta de transparência, que ainda perduram, em relação a estes crimes. Entre as medidas a serem adotadas pelo Estado brasileiro, a CrIDH decidiu que fossem investigados, processados e sancionados os agentes públicos envolvidos nos desaparecimentos.

Além disso, a CrIDH declarou que o Brasil violou o direito à justiça ao deixar de investigar aqueles crimes, ferindo uma obrigação internacional a que está submetido. As disposições da Lei de Anistia brasileira que impedem a investigação e punição de graves violações de direitos humanos foram consideradas como incompatíveis com a Convenção Americana, e por isso, no entendimento da Corte, carecem de efeitos jurídicos. A Corte declarou também que o Brasil é responsável pela violação do direito à integridade pessoal de determinados familiares das vítimas, entre outras razões, por causa do sofrimento ocasionado pela falta de investigações e de esclarecimento sobre os fatos envolvendo os desaparecimentos. Neste sentido, a sentença estabeleceu o pagamento de indenizações a 113 parentes de vítimas. Entre outras coisas, a Corte determinou também o aprofundamento das ações desenvolvidas em matéria de capacitação em direitos humanos e a implementação, em prazo razoável, de um programa permanente e obrigatório sobre a matéria para todos os níveis hierárquicos das Forças Armadas. 
Vale citar aqui algumas das principais declarações e determinações da sentença ${ }^{32}$ :

“3. As disposições da Lei de Anistia brasileira que impedem a investigação e sanção de graves violações de direitos humanos são incompatíveis com a Convenção Americana, carecem de efeitos jurídicos e não podem seguir representando um obstáculo para a investigação dos fatos do presente caso, nem para a identificação e punição dos responsáveis, e tampouco podem ter igual ou semelhante impacto a respeito de outros casos de graves violações de direitos humanos consagrados na Convenção Americana ocorridos no Brasil.

4. O Estado é responsável pelo desaparecimento forçado e, portanto, pela violação dos direitos ao reconhecimento da personalidade jurídica, à vida, à integridade pessoal e à liberdade pessoal, estabelecidos nos artigos 3, 4, 5 e 7 da Convenção Americana sobre Direitos Humanos, [...] em prejuízo das pessoas indicadas no parágrafo 125 da presente Sentença, $[\ldots]$.

5. O Estado descumpriu a obrigação de adequar seu direito interno à Convenção Americana sobre Direitos Humanos, [...] como consequência da interpretação e aplicação que foi dada à Lei de Anistia a respeito de graves violações de direitos humanos. Da mesma maneira, o Estado é responsável [...] pela falta de investigação dos fatos do presente caso, bem como pela falta de julgamento e sanção dos responsáveis, em prejuízo dos familiares das pessoas desaparecidas e da pessoa executada [...].

6. O Estado é responsável pela violação do direito à liberdade de pensamento e de expressão [...], pela afetação do direito a buscar e a receber informação, bem como do direito de conhecer a verdade sobre o ocorrido. Da mesma maneira, o Estado é responsável pela violação dos direitos às garantias judiciais estabelecidos [...], por exceder o prazo razoável da Ação Ordinária, todo o anterior em prejuízo dos familiares indicados nos parágrafos 212, 213 e 225 da presente Sentença [...].

Entretanto, até muito recentemente, boa parte dos ministros do STF não adotava uma visão sobre a obrigatoriedade de o Brasil respeitar os arestos da CrIDH. No mesmo ano de 2010, quando era presidente da Corte, Cezar Peluso afirmou que a $\mathrm{CrIDH}$ "não revoga, não anula, não caça a decisão do Supremo". Na mesma época, o ministro Marco Aurélio Mello afirmou que o direito interno deve se sobrepor ao direito internacional. Não teve vergonha de adicionar que a decisão da CrIDH "não tem concretude como título judicial. Na prática, o efeito será nenhum, é apenas uma sinalização”. No mesmo sentido, o ex-Ministro do STF e então ministro da Defesa, Nelson Jobim, disse que as decisões da CrIDH são meramente políticas e que não produzem efeitos jurídicos no Brasil. ${ }^{33}$

\footnotetext{
${ }^{32}$ As citações a seguir são constantes do tópico XII, intitulado "Pontos resolutivos", da sentença (CrIDH, 2010, p. 112-116).

${ }^{33}$ Vide reprodução dos comentários dos ministros em VENTURA, D.; QUINALHA, R. "Corte Interamericana em Brasília: uma derrota do provincianismo". Última Instância, 29 nov. 2013. Colunas. Pode ser obtido

no seguinte endereço eletrônico:
} 
Em entrevista que me concedeu em 14 de maio de 2013, o ministro Gilmar Mendes deu uma ideia ainda mais forte do demérito da CrIDH em sua visão, aparentemente partilhada por alguns de seus pares. Ao ser perguntado a respeito da importância do Sistema Interamericano de Direitos Humanos, o ministro asseverou:

"Essa é uma questão complexa, eu acho que eles têm muito que fazer na América Latina toda e pouco o que fazer no Brasil, o nosso sistema hoje é muito melhor do que qualquer desses, o nosso sistema hoje judicial, com todos os problemas, na verdade ele não tem concorrência no plano da América Latina. [...] A Costa Rica [onde fica a CrIDH] é um laboratório, uma bobagem, é uma ficção, quer dizer, é o quê? Brasília? Menos do que Brasília? [...] O modelo processual da Costa Rica, que modelo é esse? Quer dizer, é só para brincadeira. Quer dizer, é menor do que Belo Horizonte, é menor do que (daqui a pouco) Ceilândia, Taguatinga. Quer dizer, não tem instituição, para efeito de comparação institucional. [...] Todos têm muito que mais fazer lá do que aqui. [...] Mas não temos muito que receber lições deles, e também não vejo grande importância na indicação do Roberto Caldas [novo juiz brasileiro investido na $\mathrm{CrIDH}$ ] para lá. O Roberto Caldas sequer é reconhecido como jurista no Brasil. Por lá passou gente de maior peso como, por exemplo, o Cançado Trindade. [...] No Supremo, nós conhecemos o Roberto Caldas como advogado trabalhista e só" (Gilmar Mendes, entrevista concedida ao pesquisador em 2013).

No mesmo ano desta entrevista, em 2013, ciente do distanciamento entre as duas Cortes, o então presidente do Supremo, Joaquim Barbosa, convidou os membros da Corte Interamericana para a realização de sessão conjunta em Brasília, que viria a ocorrer em novembro daquele ano. $\mathrm{Na}$ ocasião, Barbosa asseverou: "O presente encontro, além de fortalecer os laços, também realça a importância atribuída pelo Poder Judiciário brasileiro à atuação da Corte IDH" ${ }^{34} \mathrm{Na}$ sessão extraordinária conjunta entre as duas Cortes foi analisado o caso dos desaparecidos na tomada do Palácio de Justiça da Colômbia por forças militares em resposta à ação do grupo político M19, em novembro de 1985.

Nitidamente dialogando com manifestações de outros ministros em casos em que a jurisprudência do STF conflitou com decisões da CrIDH diretamente dirigidas ao Brasil (como no caso Guerrilha do Araguaia), Barbosa também destacou: “A nítida compreensão da existência de uma esfera de jurisdição atribuída pelo Brasil e vários outros países latino-americanos a órgãos do Sistema Interamericano de Direitos Humanos faz dessas

http://ultimainstancia.uol.com.br/conteudo/colunas/67780/corte\%20interamericana\%20em\%20brasilia $\% 20 \mathrm{u}$ ma\%20derrota\%20do\%20provincianismo.shtml. Último acesso em 25 de março de 2015.

${ }^{34}$ Vide esta e a próxima citação do ex-ministro em "Corte IDH e STF ressaltam importância do sistema interamericano de direitos humanos". Notícias STF, Brasília, 11 nov. 2013. Disponível em: http://www.stf.jus.br/portal/cms/verNoticiaDetalhe.asp?idConteudo=253184. Último acesso em 26 de março de 2015. 
entidades internacionais órgãos integrantes da rede de atribuições jurisdicionais a que o nosso país soberanamente decidiu se submeter."

Quando o então presidente do Supremo considerava que o Brasil se submetera "soberanamente" ao Sistema Interamericano de Direitos Humanos, estava a contrariar a opinião de alguns de seus pares. Vale lembrar que Barbosa não participou da sessão de julgamento em 2010 na ADPF 153 por motivos de saúde. Mas alguns meses antes da sessão conjunta com a CrIDH, em fevereiro de 2013, o então presidente do Supremo afirmou em entrevista à rádio venezuelana La Radio del Sur que, se tivesse participado da sessão de julgamento em 2010 na ADPF 153, teria votado pela procedência ainda que parcial da petição da $\mathrm{OAB} .^{35}$

Em outubro de 2014, a Corte Interamericana (2014) publicou uma resolução acerca da "supervisão de cumprimento de sentença" relativa ao caso Guerrilha do Araguaia. ${ }^{36}$ Desde a publicação da sentença em 2010 até outubro de 2014, a Corte recebeu quatro relatórios do governo brasileiro dando conta dos esforços relacionados ao cumprimento da sentença em questão. Os representantes das vítimas - o Grupo Tortura Nunca Mais do Rio de Janeiro, a Comissão de Familiares de Mortos e Desaparecidos Políticos e o CEJIL - também enviaram 11 manifestações à Corte no período.

A CrIDH considerou que o Estado brasileiro cumpriu totalmente três das diversas recomendações e exigências de sua decisão proferida em 2010: a ampla divulgação da sentença da Corte; a abertura de prazo para a apresentação, por parte de alguns familiares de desaparecidos no Araguaia, de solicitações de indenização utilizando os critérios e mecanismos estabelecidos pela Lei dos Desaparecidos; e a criação de uma comissão da verdade. A Corte considerou como parcialmente cumpridas as determinações ou recomendações a respeito da busca, sistematização e publicação de toda a informação sobre a Guerrilha do Araguaia; o pagamento de indenização a familiares de mortos e desaparecidos na guerrilha e especificados na sentença; bem como a realização de convocatória para que alguns dos familiares também identificados na sentença pudessem ser considerados como vítimas (Cf. CrIDH, 2014, p. 40).

Contudo, a Corte expressou preocupação com o fato de que:

\footnotetext{
${ }^{35}$ Vide notícia em "Ley de amnistía brasileña puede ser modificada". Correo del Orinoco, caracas, 28 fev. 2013. Disponível em: http://www.correodelorinoco.gob.ve/judiciales-seguridad/ley-amnistia-brasilenapuede-ser-modificada/. Último acesso em 26 de março de 2015.

${ }^{36}$ A resolução de supervisão de sentença (CrIDH, 2014) pode ser encontrada no seguinte endereço eletrônico: http://www.corteidh.or.cr/docs/supervisiones/gomes_17_10_14_por.pdf. Último acesso: 26 de março de 2015.
} 
"mais de três anos e onze meses da emissão da Sentença, somente se tenham iniciado duas ações penais que compreendem unicamente dois supostos responsáveis pelas violações perpetradas em detrimento de 6 das 62 pessoas declaradas como vítimas no presente caso e que, atualmente, ambas as ações estão paralisadas em virtude de decisões judiciais favoráveis aos acusados nos recursos de habeas corpus" (CrIDH, 2014, p. 08).

Atualmente, a ADPF 153 está pendente de julgamento de "embargos de declaração", recurso veiculado pela OAB justamente visando uma resposta do Supremo sobre a sentença de 2010 da CrIDH. A AGU, por exemplo, já se manifestou afirmando, entre outras razões, que acatar a decisão da CrIDH equivaleria a violar a soberania do Estado brasileiro, onde o STF deve ter a última palavra em matéria judicial.

3.2.2) Ações penais ajuizadas pelo MPF e as variadas reações da Justiça Federal

O propósito neste tópico será abordar em linhas gerais, se não todas, pelo menos a maior parte das ações penais em andamento ajuizadas pelo MPF contra agentes da repressão militar até aqui. ${ }^{37}$ Além do desenvolvimento das ações, alguns dos principais argumentos mobilizados tanto pelo MPF quanto pela Justiça Federal serão destacados.

Em 2013, a 2 $2^{\text {a }}$ Câmara de Coordenação e Revisão do MPF (área criminal e de controle externo da atividade policial) divulgou relatório sobre a atuação da instituição na persecução penal dos crimes ocorridos durante a ditadura. Nos termos da portaria que instituiu o chamado Grupo de Trabalho Justiça de Transição (GTJT), é tarefa do grupo examinar as consequências criminais da sentença da Corte Interamericana no caso Guerrilha do Araguaia e dar cumprimento parcial a ela, pelo menos no que diz respeito às atribuições do MPF, relativas à persecução penal dos agentes públicos envolvidos em graves violações aos direitos humanos. No entendimento da instituição, não haveria um problema de soberania envolvido no conflito entre as decisões do STF na ADPF 153 e da CrIDH no caso Guerrilha do Araguaia porque esta última Corte possui competência funcional em matéria de direitos humanos, tendo, portanto, preferência na jurisdição sobre a matéria. O relatório consubstancia os fundamentos da decisão do MPF de tomar (e mudar) sua posição institucional sobre o tema.

\footnotetext{
${ }^{37}$ Até março de 2015, quando o presente capítulo foi finalizado.
} 
Na narrativa que fez sobre o histórico de constituição do GTJT, o relatório (MPF, 2013, p. 12 e seguintes) atestou que, até 2011, requerimentos de arquivamentos de representações atinentes a casos que em tese estariam cobertos pela interpretação corrente da Lei de Anistia eram a regra na instituição. ${ }^{38}$ Apenas em fevereiro de 2011, depois da sentença da CrIDH no caso Guerrilha do Araguaia, uma Câmara da Procuradoria Regional da República em São Paulo não homologou um destes requerimentos de arquivamento, relacionado aos desaparecimentos de Aluízio Palhano Pedreira Ferreira e Luiz Almeida Araújo. ${ }^{39}$ No mesmo ano, membros do MPF participaram de Workshop sobre justiça de transição em conjunto com a Secretaria Nacional de Justiça (encabeçada por Paulo Abrão, também presidente da Comissão de Anistia) e o ICTJ (International Center for Transitional Justice). Deste Workshop teria surgido o impulso para a organização do GT.

Até o começo de 2013, as ações ajuizadas pelo MPF no âmbito da justiça de transição diziam respeito a casos que poderiam se encaixar na tese do sequestro e que, portanto, na concepção da instituição, não seriam abrangidos pela Lei de Anistia. Desencadeou-se, então, um grande empreendimento investigativo para a montagem dos processos: além do esforço de sistematização das informações e documentos que órgãos do governo e familiares acumularam nas últimas décadas, os membros do GT se engajaram em realizar novas entrevistas e conseguir novos documentos mediante a legislação mais permissiva para sua obtenção junto a órgãos da Administração Pública.

Até o final de 2012, o MPF denunciou os seguintes agentes da repressão: Sebastião Curió Rodrigues de Moura, ex-integrante do quadro do Exército Brasileiro, engajado na terceira incursão das Forças Armadas na região da Guerrilha do Araguaia; Carlos Alberto Brilhante Ustra, ex-comandante operacional do DOI-CODI do Segundo Exército em São Paulo; Dirceu Gravina, ex-integrante da equipe de interrogatório do DOI-CODI e atual delegado da Polícia Civil de São Paulo; Alcides Singillo, delegado de Polícia Civil aposentado, lotado no DEOPS/SP à época; Carlos Alberto Augusto, ex-investigador de polícia, também lotado no DEOPS/SP no período ditatorial e delegado na ativa atualmente; e Lício Augusto Maciel, ex-major e ex-integrante do Centro de Informações do Exército (CIE), órgão federal incumbido do planejamento das ações de repressão política aos dissidentes do regime.

\footnotetext{
${ }^{38}$ O relatório intitulado Crimes da Ditadura (MPF, 2013) pode ser obtido no seguinte endereço: http://noticias.pgr.mpf.mp.br/noticias/noticias-dosite/copy_of_pdfs/Relatorio_Crimes\%20_Ditatura_completo.pdf. Último acesso: 26 de março de 2015.

${ }^{39}$ Houve, entretanto, desde a década de 1990 , algumas tentativas de ajuizamento de ações penais por alguns procuradores, especialmente alguns dos que viriam a estar envolvidos na fundação e liderança do GTJT, como Marlon Weichert e Eugênia Gonzaga.
} 
O coronel conhecido como "major Curió" foi denunciado sob a acusação de ter atuado no desaparecimento de cinco participantes da Guerrilha do Araguaia ${ }^{40}$, organizada pelo $\mathrm{PCdoB}$ na região entre o sul do Pará e o norte do Tocantins (na época Goiás). ${ }^{41} \mathrm{O}$ argumento utilizado foi inspirado em ações semelhantes em outros países, como o Chile, onde as primeiras condenações de antigos agentes da repressão foram resultado da consideração do desaparecimento (ou sequestro, na tipologia brasileira) como um crime permanente. O processo foi suspenso por cerca de um ano, por decisão liminar do juiz federal da primeira instância. Segundo ele, a Lei de Anistia e a Lei dos Desaparecidos encetavam a "impossibilidade jurídica" do pedido (Cf. MPF, 2013, p. 52 e seguintes). No recurso, o MPF se empenhou na argumentação acerca da característica de crimes de lesahumanidade dos delitos praticados por Curió e seus correligionários. O Tribunal Regional Federal (TRF) da $1^{\text {a }}$ Região então repetiu o argumento aventado por aquele e por outros magistrados em primeira instância, segundo o qual a Lei 9.140/1995, ao atestar a morte dos desaparecidos para fins legais, determinou o termo inicial de contagem da prescrição, que já teria se exaurido.

Decisões como estas atestam a possibilidade de continuidade discursiva sobre a impunidade e o esquecimento entre a Lei de Anistia e a Lei dos Desaparecidos. Esta ação penal foi depois trancada em 2014 pelo TRF da $1^{\text {a }}$ Região e aguarda agora processamento de recurso nas instâncias superiores. ${ }^{42}$

A ação contra Lício Augusto Maciel foi recebida em primeira instância. Não encontrado, o antigo major foi citado por edital. Lício Maciel foi mais um militar que participou da repressão à Guerrilha do Araguaia e foi identificado na denúncia como responsável pelo desaparecimento de Divino Ferreira de Souza, o Nunes, em outubro de 1973. Na mesma emboscada também desapareceram André Grabois, João Gualberto Calatroni e Antônio Alfredo de Lima. Entretanto, em 2014, a ação penal foi igualmente trancada em sede de habeas corpus junto ao TRF da $1^{\text {a }}$ Região. ${ }^{43}$

\footnotetext{
${ }^{40}$ São eles Maria Célia Corrêa, Hélio Luiz Navarro Magalhães, Daniel Ribeiro Callado, Antônio de Pádua e Telma Regina Cordeira Corrêa.

${ }^{41}$ Para acompanhamento processual deste caso, vide o seguinte link da Justiça Federal na $1^{\text {a }}$ Região: http://processual.trf1.jus.br/consultaProcessual/processo.php?proc $=62319220124013901 \&$ secao $=$ MBA.

Último acesso em 26 de março de 2015.

${ }^{42}$ A respeito, vide notícia de LUCHETE, F. "TRF-1 mantém ação que acusa coronel Curió de sequestro". Consultor Jurídico. São Paulo, 29 jul. 2014. Disponível em: http://www.conjur.com.br/2014-jul-29/trfmantem-trancada-acao-acusa-coronel-curio-sequestro. Último acesso: 26 de março de 2015.

${ }^{43}$ Para acompanhamento processual deste caso, vide o seguinte link da Justiça Federal na $1^{\text {a }}$ Região: http://processual.trf1.jus.br/consultaProcessual/processo.php?proc=62327720124013901\&secao=MBA\&env iar=Pesquisar. Último acesso em 26 de março de 2015.
} 
As ações ajuizadas contra Curió e Maciel dizem respeito a condutas praticadas pelos militares no curso da denominada Operação Marajoara, já na última fase dos combates entre as Forças Armadas e os militantes da guerrilha. Segundo relato do MPF nos processos:

"Nessa etapa houve o deliberado e definitivo abandono do sistema normativo vigente, pois decidiu-se claramente pela adoção sistemática de medidas ilegais e violentas, promovendo-se então o sequestro ou a execução sumária dos militantes. Não há notícias de sequer um militante que, privado da liberdade pelas Forças Armadas durante a Operação Marajoara, tenha sido encontrado livre posteriormente." 44

O coronel reformado Brilhante Ustra e Dirceu Gravina foram denunciados pelo sequestro qualificado do bancário e líder sindical Aluízio Palhano Pedreira Ferreira, preso ilegalmente em maio de 1971 nas dependências do DOI-CODI do Segundo Exército. Mais tarde, Palhano seria levado à famosa "Casa de Petrópolis", centro clandestino de torturas mantido pelo CIE. Conforme mencionado acima, Ustra era comandante operacional do DOI-CODI entre setembro de 1970 e janeiro de 1974, período que mais registrou casos conhecidos de tortura, execução sumária e desaparecimento sob os auspícios das forças de segurança em São Paulo. Dos 64 casos de sequestros e homicídios associados ao DOICODI paulista, 47 foram cometidos no período em que Ustra esteve à frente do órgão (Cf. MPF, 2013, p. 60).

Já Dirceu Gravina integrava as equipes de interrogatórios do DOI-CODI e atualmente é delegado da Polícia Civil do Estado de São Paulo. A Justiça Federal no Estado rejeitou a denúncia em maio de 2012 sob o argumento da anistia e da prescrição dos crimes, decisão que foi ratificada por maioria em acórdão do TRF da $3^{\text {a }}$ Região. ${ }^{45}$

Outra ação ajuizada pelo MPF foi contra o mesmo coronel reformado Brilhante Ustra, Alcides Singillo e Carlos Alberto Augusto ${ }^{46}$, pelo sequestro e desaparecimento de Edgar de Aquino Duarte, que participou da revolta dos marinheiros em 1964, depois exilou-se por alguns anos no México e em Cuba até voltar ao Brasil em 1968, sendo

\footnotetext{
${ }^{44}$ Vide notícia do site do MPF "Justiça recebe denúncia contra militares por sequestros na guerrilha do Araguaia”. Ministério Publico Federal, Sala de Imprensa. São Paulo, 30 ago. 2012. Notícias. Disponível em: http://www.prsp.mpf.gov.br/sala-de-imprensa/noticias_prsp/30-08-12-justica-recebe-denuncia-contramilitar-por-sequestro-na-guerrilha-do-araguaia. Último acesso: 25 de março de 2015.

45 acórdão mencionado pode ser obtido pelo seguinte link: http://web.trf3.jus.br/acordaos/Acordao/BuscarDocumentoGedpro/2563095. Último acesso em 26 de março de 2015.

${ }^{46}$ Carlos Alberto Augusto, além de ter trabalhado no DOI-CODI, também participou da equipe do famoso delegado Sérgio Paranhos Fleury (já falecido), a cujo comando também se atribuem vários homicídios, desaparecimentos e torturas durante a ditadura militar.
} 
ilegalmente preso nas dependências do DEOPS-SP em junho de 1971. Duarte foi delatado por José Anselmo dos Santos, o "Cabo Anselmo", alegadamente sob tortura (Cabo Anselmo prestaria o serviço de agente duplo junto a militantes opositores para passar informações ao Segundo Exército).

A denúncia foi recebida em primeira instância em outubro de 2012, com base nos julgamentos das Extradições 974 e 1.150, julgadas pelo STF e comentadas acima. A decisão também se reportou à sentença da $\mathrm{CrIDH}$ acerca do caráter sistemático das violações praticadas pelas forças de segurança no período. Um habeas corpus para trancamento da ação junto ao TRF da $3^{\text {a }}$ Região não foi concedido. Trata-se do processocrime com andamento mais adiantado entre os promovidos pelo GTJT. Nas audiências promovidas entre 09 e 11 de dezembro de 2013, ex-presos políticos testemunharam torturas e outras graves violações de direitos humanos que sofreram no DOI-CODI e no DEOPS de São Paulo. Também reportaram ao juiz os atos nefastos cometidos pelos acusados ali sentados, Augusto e Singillo, e também por Ustra, que não compareceu às audiências. Pela primeira vez, a arena judicial criminal se abriu para escutar a voz das vítimas. $^{47}$

Em fevereiro de 2014, a Justiça Federal no Rio aceitou a denúncia contra os seis acusados pelo MPF de terem se envolvido no atentado a bomba no Riocentro, em 1981. O atentado, organizado por um grupo da linha-dura do regime militar, provocou a explosão de duas bombas no Riocentro em 30 de abril de 1981, durante um show em comemoração pelo Dia do Trabalhador, que seria dois dias depois, em $1^{\circ}$ de maio. A denúncia responsabiliza, dentre outros, os generais Newton Cruz e Nilton Cerqueira, respectivamente, chefe da Agência Central do Serviço Nacional de Informações (SNI) e comandante da Polícia Militar fluminense à época do atentado. Além dos denunciados, outros nove responsáveis já falecidos também foram identificados pela denúncia. Em 1981, o primeiro inquérito aberto pelo Exército concluíra que o sargento Rosário, que morreu no atentado, e o capitão Machado, gravemente ferido, haviam sido antes vítimas, e não autores do crime. De lá para cá, houve pelo menos quatro tentativas frustradas de instauração de processos criminais contra agentes das forças de segurança por conta do atentado.

\footnotetext{
${ }^{47}$ Ustra e Singillo também eram réus em processo sobre a ocultação de cadáver do corpo de Hirohaki Torigoe, desaparecido sob os auspícios dos militares desde janeiro de 1972. Entretanto, em janeiro de 2014, a Justiça Federal declarou em primeira instância extinta a punibilidade dos réus. $\mathrm{O}$ argumento utilizado pelo magistrado foi o da prescrição. Já a ação pela prática de sequestro de Torigoe qualificado corre na $9^{\text {a }}$ Vara Federal Criminal da $3^{\mathrm{a}}$ Região.
} 
A denúncia de 2014 argumentou que novas provas foram produzidas e que o caso não é coberto pela Lei de Anistia, que produziu seus efeitos para fatos ocorridos antes de sua publicação, em 1979. Os réus passaram a responder pelos crimes de tentativa de homicídio doloso, associação em organização criminosa, transporte de explosivos, favorecimento pessoal e fraude processual.

A decisão de primeira instância acatou a argumentação do Ministério Público sobre as condutas em questão serem classificadas como crime contra a humanidade, que "foram cometidos por agentes do Estado, como forma de perseguição política, no período da Ditadura Militar como atos de repressão à liberdade política da vítima". ${ }^{48}$ A decisão também se reportou à imprescritibilidade deste tipo de crime segundo o direito internacional costumeiro, bem como à legislação internacional, especialmente Convenções da Organização dos Estados Americanos (OEA).

Entretanto, o caso sofreu uma reviravolta na segunda instância: por dois votos a um, o TRF da $2^{\text {a }}$ Região acolheu o habeas corpus pedido pela defesa de quatro réus e trancou o processo. Dois desembargadores entenderam que a ação está prescrita, uma vez que as condutas em questão não poderiam ser enquadradas como crimes contra a humanidade. Para o relator, desembargador federal Ivan Athié, "não podemos admitir que normas alienígenas sejam usadas como se integrassem o ordenamento jurídico brasileiro, em nome de um sentimento de justiçamento perigosamente em voga no nosso país atualmente". ${ }^{49}$ Este trancamento da ação penal tem seguido a tendência da maioria dos casos que chegam à segunda instância da Justiça Federal.

Também em 2014, a Justiça Federal instaurou ação penal contra os cinco militares acusados pelo MPF de participar da morte e da ocultação do cadáver do então deputado Rubens Paiva, em 1971. O parlamentar havia sido preso durante a ditadura militar e morreu após ser barbaramente torturado no DOI-CODI do Rio. Seu corpo nunca foi entregue à família. O juiz da $4^{\mathrm{a}}$ Vara Federal Criminal do Rio entendeu que os crimes atribuídos aos militares são crimes contra a humanidade, por isso não sujeitos à aplicação da Lei de Anistia. Os réus são o general reformado José Antonio Nogueira Belham, os coronéis reformados Rubens Paim Sampaio e Raymundo Ronaldo Campos e os exsargentos Jurandyr Ochsendorf e Souza e Jacy Ochsendorf e Souza. Outros nove envolvidos foram identificados, mas já faleceram.

\footnotetext{
${ }^{48}$ Conferir trechos da decisão em "Ação contra acusados do atentado no Riocentro é trancada no TRF-2". Consultor Jurídico. São Paulo, 2 jul. 2014. Disponível em: http://www.conjur.com.br/2014-jul-02/acaoacusados-atentado-riocentro-trancada-trf. Último acesso: 26 de março de 2015.

${ }^{49}$ Ibid. id.
} 
Na decisão pelo recebimento da denúncia, o juiz de primeira instância afirmou que a Anistia "deve ser interpretada restritivamente, (..) sobretudo quando colide com a proteção de direitos fundamentais". Para o magistrado, a tortura e o assassinato de presos políticos na ditadura "fazia parte de uma política conhecida, desejada e coordenada pela mais alta cúpula governamental, mas que a manteve em um plano de ilegalidade". ${ }^{50} \mathrm{O}$ TRF da $2^{\mathrm{a}}$ Região denegou por unanimidade o pedido liminar de habeas corpus para o trancamento da ação sobre o caso. Foi a primeira vez que um tribunal brasileiro reconheceu as violações de direitos humanos cometidas por agentes da repressão como crimes contra a humanidade. Vale lembrar que esta denúncia, diferentemente da grande maioria e da estratégia fundamental adotada pelo MPF até pelo menos 2013, não foi por sequestro qualificado, mas por homicídio triplamente qualificado, ocultação de cadáver e associação criminosa armada. ${ }^{51}$

Entretanto, em setembro de 2014, o ministro Teori Zavascki, do STF, deferiu liminar na Reclamação 18.686 para determinar a suspensão da ação penal do caso Rubens Paiva. Em análise preliminar do caso, o relator argumentou que o recebimento da denúncia pelo juízo de primeira instância era incompatível com a decisão do STF no julgamento da ADPF 153:

"São relevantes os fundamentos deduzidos na presente reclamação. Em juízo de verossimilhança, não há como negar que a decisão reclamada é incompatível com o que decidiu esta Suprema Corte no julgamento da ADPF 153, em que foi afirmada a constitucionalidade da Lei 6.683/1979 (Lei de Anistia) e definido o âmbito da sua incidência (crimes políticos e

\footnotetext{
${ }^{50}$ Vide notícia FRANCO, B. "Juiz abre processo contra militares acusados de matar Rubens Paiva". Folha de São Paulo. São Paulo, 26 maio 2014. Caderno Poder. Disponível em: http://www1.folha.uol.com.br/poder/2014/05/1460231-juiz-afasta-anistia-e-abre-processo-contra-militaresacusados-de-matar-rubens-paiva.shtml. Último acesso: 26 de março de 2015.

${ }^{51} \mathrm{O}$ coronel reformado Paulo Malhães contou ao jornal $O$ Dia que recebeu uma ordem do gabinete do ministro do Exército em 1973 para desenterrar o corpo de Rubens Paiva, que estava na areia, na Praia do Recreio dos Bandeirantes, a fim de ocultá-lo definitivamente. Na entrevista ao jornal, Malhães contou que participaram da missão junto com ele o coronel reformado José Brandt Teixeira, os sargentos Jairo de Canaan Cony e Iracy Pedro Interaminense Corrêa. Apenas Cony estava falecido. Mas o próprio Malhães morreu 37 dias depois da entrevista ao jornal, durante um assalto em sua casa, em circunstâncias ainda não esclarecidas e sob investigação. Após a morte, a viúva de Malhães contou a $O$ Dia que ele admitiu a ela ter participado da operação e que os restos mortais de Rubens Paiva foram jogados em um rio. Veja notícia PIVA, J. D. "Coronel revela como sumiu com o corpo de Rubens Paiva”. O Dia Online. Rio de Janeiro, 20 de março de 2014. Disponível em: http://odia.ig.com.br/noticia/brasil/2014-03-20/coronel-revela-comosumiu-com-corpo-de-rubens-paiva.html. Último acesso: 26 de março de 2015. Em 2012, o coronel da reserva Júlio Miguel Molina Dias, de 78 anos, que foi chefe do Departamento de Operações de Informação do DOI-CODI no Rio, foi assassinado com seis tiros quando chegava de carro em sua casa, em Porto Alegre, numa aparente tentativa de roubo de um arsenal de armas que o militar colecionava. O coronel Molina Dias também é um dos já falecidos que teriam estado envolvidos com a morte de Rubens Paiva.
} 
conexos no período de 02/09/1961 a 15/08/1979, entre outros)" (Zavascki, 2014). ${ }^{52}$

No mesmo mês da decisão monocrática de Zavascki no caso Rubens Paiva, porém, o MPF denunciou três militares pela morte do jornalista Luiz Eduardo da Rocha Merlino, em julho de 1971, auge da ditadura no país. O coronel reformado Carlos Alberto Brilhante Ustra, o delegado Dirceu Gravina e o servidor aposentado Aparecio Laertes Calandra são acusados por homicídio doloso qualificado neste caso. Além deles, o médico legista Abeylard de Queiroz Orsini, que assinou laudos sobre a morte de Merlino, também foi denunciado por falsidade ideológica. ${ }^{53} \mathrm{O}$ MPF pleiteia também a exoneração dos acusados de seus cargos públicos e aposentadorias, e requer também que, enquanto tramitar o processo, Gravina seja afastado cautelarmente do cargo de delegado da Polícia Civil, bem como que seja vedado a Orsini o exercício da medicina. Entretanto, o juiz de primeira instância rejeitou a denúncia com base no argumento segundo o qual a anistia extingue todos os efeitos penais das condutas e se caracteriza pelo esquecimento jurídico do ilícito. A decisão citou amplamente o julgamento do STF na ADPF 153 e a questão do aspecto histórico da anistia de 1979 e sua introdução na Constituição de 1988 pela EC 26/1985.

Já em 2015, em janeiro, a Justiça Federal de São Paulo rejeitou mais uma denúncia feita pelo MPF contra o coronel reformado Carlos Alberto Brilhante Ustra, Dirceu Gravina e Aparecido Laerte Calandra pela morte do militante Hélcio Pereira Fortes, em janeiro de $1972 .{ }^{54}$ De acordo com a juíza substituta Andréia Silva Sarney Costa Moruzzi, da $1^{\text {a }}$ Vara Criminal Federal de São Paulo, os fatos ocorreram em 1971, durante a ditadura militar, razão pela qual "é forçoso reconhecer a extinção da punibilidade, em decorrência da concessão de anistia". ${ }^{5}$

Neste período de cerca de quatro anos de ações ajuizadas pelo MPF (entre 2012 e começo de 2015, inclusive, por enquanto), a instituição passou das tentativas da tipificação de sequestro em relação aos desaparecidos (que mais nitidamente evitava o enfrentamento em relação à interpretação da anistia enquanto "bilateral") para tentativas

\footnotetext{
${ }^{52}$ A decisão pode ser obtida em: http://www.jusbrasil.com.br/diarios/documentos/142705003/medidacautelar-na-reclamacao-n-18686-do-stf. Último acesso em 26 de março de 2015.

${ }^{53}$ Vide notícia sobre a denúncia em "MPF denuncia coronel Ustra por morte de jornalista na ditadura". Consultor Jurídico. São Paulo, 22 set. 2014. Disponível em: http://www.conjur.com.br/2014-set-22/mpfdenuncia-coronel-ustra-morte-jornalista-ditadura. Último acesso: 26 de março de 2015.

${ }^{54}$ Hélcio era ligado ao Partido Comunista Brasileiro (PCB) e dirigente da Ação Libertadora Nacional (ALN).

${ }^{55}$ Ver trechos da decisão em ROVER, T. "Justiça Federal de São Paulo rejeita nova denúncia contra coronel Ustra”. Consultor Jurídico. São Paulo, 20 jan. 2015. Disponível em: http://www.conjur.com.br/2015-jan20/justica-federal-sp-rejeita-denuncia-coronel-ustra. Último acesso: 25 de março de 2015.
} 
também no sentido da persecução penal de casos em que se tem notícia oficial a respeito da morte da vítima, tratando-se, portanto, de homicídio, entre outros crimes. O GTJT pode ter entendido que não poderia esperar o desfecho das tentativas de fazer valer a tese do sequestro em relação aos casos de desaparecimento antes de passar a contestar mais seriamente a abrangência da Lei de Anistia por meio da tese dos crimes contra a humanidade em casos de homicídio qualificado associado a outros crimes. Em parte, esta mudança de estratégia pode ser explicada pelo fato de muitas das ações relativas à tese do sequestro enfrentarem um percurso difícil com não rara resistência da Justiça Federal, sobretudo em segunda instância, como vimos, somada à morosidade usual da tramitação dos processos.

Mesmo assim, vale frisar que a tese dos crimes contra a humanidade, apesar de essencial para a atualização do direito brasileiro em relação ao direito internacional dos direitos humanos, tem um paralelo com a tese do crime permanente na medida em que não coloca em xeque a validade da chamada "anistia bilateral", mas apenas a sua extensão. Os crimes contra a humanidade, sendo insuscetíveis de anistia, não poderiam ser perdoados pela Lei 6.683/1979. Nada impediria que outros crimes, mesmo praticados por agentes públicos, contudo, como peculato ou corrupção passiva, possam ser abrangidos pela lei, segundo esta linha argumentativa.

Este raciocínio mostra que, pelas linhas argumentativas até aqui desenvolvidas no bojo destas ações, a Lei de Anistia tem sua "bilateralidade" bastante comprimida, mas não totalmente contestada. Nas palavras do próprio Procurador Regional da República que assina as petições do caso Rubens Paiva, Sérgio Suiama (que é também coordenador substituto do GTJT): "Não estamos discutindo a validade da lei [ou de sua bilateralidade, mais precisamente]". ${ }^{56} \mathrm{Eu}$ acrescentaria: discute-se apenas a extensão desta bilateralidade, que na visão do MPF, bastante resistida pela Justiça Federal, como vimos, não abrangeria crimes permanentes e crimes contra a humanidade, mas poderia, por exclusão, abranger outros delitos não enquadrados nestas categorias, como corrupção ativa e passiva, peculato, dentre outros.

Contestar a anistia a agentes da repressão com relação a estes crimes poderia parecer uma empresa sem efeito prático para a persecução penal na atualidade em função de já terem todos prescrito, pois não se lhes aplica a "permanência" existente no sequestro

\footnotetext{
${ }^{56}$ Cf. depoimento do procurador reproduzido em PIVA, J. D. "TRF reconhece que Lei de Anistia não abrange crimes contra a humanidade". O Dia. Rio de Janeiro, 10 set. 2014. Caderno Brasil. Disponível em: http://odia.ig.com.br/noticia/brasil/2014-09-10/trf-reabre-acao-contra-militares-acusados-de-homicidio-dedeputado.html. Último acesso: 26 de março de 2015.
} 
ou a imprescritibilidade dos crimes contra a humanidade. Entretanto, para um magistrado, por exemplo, que em hipótese alguma aplicaria uma tipologia de "direito internacional costumeiro", como é o caso dos crimes de lesa-humanidade no Brasil, a contestação da "bilateralidade" da anistia poderia ser um caminho alternativo para a persecução penal relacionada à tortura, ao desaparecimento forçado, homicídio, entre outros. Do ponto de vista do engajamento do MPF nos processos, o ataque à anistia para os agentes da repressão, portanto, poderia ter algum valor ao menos como tese subsidiária às teses do crime permanente e dos crimes contra a humanidade. Além disso, de um ponto de vista mais estritamente "político", a visão sobre a "bilateralidade" da anistia representa, na verdade, a expressão em direito penal da chamada "teoria dos dois demônios" e da possibilidade de um regime, ainda sob os auspícios autoritários, poder anistiar, pelo menos até certo ponto, os agentes repressivos que atuaram ou atuam em seu nome.

\subsection{3) O parecer da PGR na ADPF 320, os Projetos de Lei pela revogação da bilateralidade da anistia e os novos ministros do STF}

No segundo semestre de 2013, Rodrigo Janot assumiria a PGR em substituição a Roberto Gurgel. A investida de Janot no cargo coincidiria com o amadurecimento das ações penais ajuizadas pelo MPF contra agentes da repressão. Sinalizando a mudança de posicionamento da instituição, o novo procurador-geral da República escreveria, no bojo da Extradição 696, que, "na persecução de crimes contra a humanidade, em especial no contexto da passagem de um regime autoritário para a democracia constitucional, carece de sentido invocar o fundamento jurídico geral da prescrição". E continuou: "Nos regimes autoritários, os que querem o socorro do direito contra os crimes praticados pelos agentes respectivos não deixam de obtê-lo porque estão dormindo, e sim porque estão de olhos fechados, muitas vezes vendados; não deixam de obtê-lo porque estão em repouso, e sim porque estão paralisados, muitas vezes manietados" (PGR, 2013, p. 14). ${ }^{57}$

Nesta Extradição e no bojo de outra ADPF, de número 320, a PGR passou a acolher o entendimento mais assentado na jurisprudência e na normativa internacionais a respeito do tema. O objetivo da ADPF 320, ajuizada pelo PSOL, é o reconhecimento pelo STF da validade e do efeito vinculante da decisão da Corte Interamericana no caso

\footnotetext{
${ }^{57}$ A manifestação do procurador-geral nesta Extradição pode ser obtida no seguinte endereço eletrônico: http://noticias.pgr.mpf.mp.br/noticias/noticias-do-site/copy_of_pdfs/ppe_696.pdf. Último acesso em 26 de março de 2015.
} 
Araguaia, requerendo que se declare que a Lei de Anistia não se aplica às graves violações de direitos humanos cometidas por agentes públicos, militares ou civis. Janot manifestouse pela procedência parcial da ação do PSOL, que constitui em sua opinião importante contribuição para fortalecer o Sistema Interamericano de Direitos Humanos e para materializar a justiça de transição no Brasil.

Para o procurador-geral, crimes graves cometidos por agentes do Estado, civis ou militares, durante a ditadura militar são imprescritíveis e insuscetíveis de anistia. Segundo seu entendimento, o objetivo da repressão era "o desmantelamento, a qualquer custo, independentemente das regras aplicáveis, das organizações de oposição, especialmente as envolvidas em ações de resistência armada" (PGR, 2014, p. 64). Janot também descreveu e colocou em anexo à sua petição relatório sobre as atividades de persecução penal do Ministério Público Federal.

Este parecer indicou a clara mudança de posição do MPF e da PGR enquanto instituições e procurava levar ao STF a possibilidade de se processar agentes públicos que cometeram graves violações aos direitos humanos para além da hipótese do sequestro, uma vez que Janot dispôs a tese dos crimes contra a humanidade no foco de sua argumentação. Segundo o parecer, as nove persecuções promovidas pelo MPF atestariam a sistematicidade das violações praticadas pelas forças de segurança. Janot também manifestou-se pelo cumprimento da decisão da $\mathrm{CrIDH}$, que teria efeito vinculante no sistema judicial brasileiro. Ao fim do parecer, o procurador-geral pediu ao STF o não reconhecimento da abrangência da Lei de Anistia sobre crimes continuados (como o sequestro) e sobre crimes contra a humanidade.

Ainda em 2011, o Projeto de Lei (PL) 573/2011, de autoria da deputada Luiza Erundina (PSB-SP), pretendia dar "interpretação autêntica" ao disposto no art. $1^{\circ}, \S 1^{\circ}$, da Lei de Anistia, postulando não se incluírem entre os crimes conexos os delitos cometidos por agentes públicos, militares ou civis, contra pessoas que efetiva ou supostamente praticaram crimes políticos. ${ }^{58} \mathrm{O}$ parágrafo único do art. $2^{\mathrm{o}}$ deste projeto estabelecia que qualquer disposição de exclusão da punibilidade destes agentes deveria ser afastada. Além de citar trechos da decisão da CrIDH sobre o caso Araguaia, a justificação do projeto

\footnotetext{
${ }^{58}$ Este projeto também tinha o condão de dar cumprimento a alguns dos dispositivos da sentença da CrIDH sobre o caso Gomes Lund e outros versus Brasil (o caso Guerrilha do Araguaia). A ele foi anexado o PL 1.124/2011, do deputado Chico Alencar (PSOL-RJ), o qual recuperava o PL 7.430/2010, da deputada Luciana Genro (PSOL-RS), que por sua vez remetia a uma tentativa no mesmo sentido realizada em 1999 pelo então deputado Marcos Rolim (PT-RS). O PL 573/2011 está disponível no site da Câmara em: http://www.camara.gov.br/proposicoesWeb/fichadetramitacao?idProposicao=493311. Último acesso em 26 de março de 2015.
} 
defendia que a isenção de responsabilidade penal por crimes contra a humanidade viola a Constituição Federal, não tendo sido por ela recepcionada. Por isso, contrariava abertamente o entendimento do STF sobre o tema.

Em setembro de 2011, a Comissão de Relações Exteriores e de Defesa Nacional da Câmara seguiu o parecer do deputado Vitor Paulo (PRB-RJ) e rejeitou o projeto. Em seu parecer $^{59}$, o deputado reiterou a ideia de que a anistia foi fato histórico que deitou o chão sobre o qual se sustenta nossa democracia. Também citando o jurista Lauro Joppert Swensson Jr. (2007), Vitor Paulo escreveu que a Lei de Anistia seria axiologicamente injusta ou ilegítima, mas juridicamente válida, e por isso teria efeito vinculante no ordenamento (Vitor Paulo, 2011). Assim como o Acórdão do STF sobre a ADPF 153, o deputado ressaltou que a EC 26/1985 seria uma "norma-origem", integrando a própria Constituição de 1988. Segundo ele, a Lei de Anistia veio a formalizar acordo no sentido de perdoar e esquecer. O parecer também se referiu a declarações da presidente Dilma Rousseff na imprensa, segundo as quais não haverá espaço para "revanchismo" e os termos originais da anistia serão mantidos.

Em dezembro de 2012, a Comissão de Constituição e Justiça e de Cidadania da Câmara também emitiu o parecer do deputado Luiz Pitiman (PMDB-DF) ${ }^{60}$, que propugnou pela antijuridicidade, inconstitucionalidade e rejeição do PL. Na avaliação do peemedebista, os crimes praticados por agentes públicos:

\begin{abstract}
"Embora crimes comuns, não há a menor dúvida de que eles se relacionavam ao contexto político, razão pela qual um dos projetos tenta excluir exatamente esses atos praticados contra pessoas acusadas de crimes contra a segurança nacional e à ordem política e-social. Portanto, são crimes políticos e, nessa condição, passíveis de anistia, segundo o fim histórico desse instituto" (Pitiman, 2012, p. 03).
\end{abstract}

E, mais adiante: "Nesse sentido, o projeto além de inconveniente é inoportuno. Melhor a Lei n. ${ }^{\circ}$ 6.683, de 1979, com o fim pragmático de esquecimento, com vista a estabelecer a paz social, além de garantir a autoridade dos poderes constituídos sob a nova ordem jurídica” (Pitiman, 2012, p. 05).

\footnotetext{
${ }^{59}$ Também disponível no site da Câmara dos Deputados pelo seguinte endereço eletrônico: http://www.camara.gov.br/proposicoesWeb/fichadetramitacao?idProposicao=493311. Último acesso em 26 de março de 2015.

${ }^{60} \mathrm{O}$ parecer (Pitiman, 2012) pode ser encontrado no seguinte endereço eletrônico: http://www.camara.gov.br/proposicoesWeb/prop_mostrarintegra;jsessionid=219EE3F3CC28B72732C8898 FEF98274E.proposicoesWeb2?codteor=1053194\&filename=Parecer-CCJC-21-12-2012. Último acesso em 25 de março de 2015.
} 
Já no Senado Federal, no primeiro semestre de 2014, os senadores da Comissão de Direitos Humanos e Legislação Participativa aprovaram projeto similar do senador Randolfe Rodrigues (PSOL-AP). O projeto (Rodrigues, 2013) declara extinta, de maneira retroativa, a prescrição dos crimes contra a humanidade cometidos por agentes públicos durante a ditadura. ${ }^{61} \mathrm{O}$ autor da proposta afirmou que a mudança na lei não tem caráter revanchista, mas o propósito de mostrar que o país não tolera mais crimes contra os direitos humanos, como a tortura.

O relator da Comissão que emitiu o parecer sobre a proposta, senador João Capiberibe (PSB-AP), sustentou que: "A própria premissa de que a anistia seria condição para a redemocratização pacífica atesta que essa lei nada mais era do que um pacto leonino entre a ditadura e a sociedade”. E continuou: “[...]não houve na negociação da anistia igualdade de posições entre a sociedade, refém de um regime repressivo, e seus carcereiros" (Capiberibe, 2014, p. 03). ${ }^{62}$

Do julgamento de 2010 no bojo da ADPF 153 para cá, quatro novos ministros foram empossados no STF, e uma quinta posição aguarda indicação da Presidência da República para ser preenchida e completar os 11 ministros da Corte. Esta perspectiva animou alguns grupos de ativistas em direitos humanos com a expectativa de que pudesse haver alguma mudança de posicionamento da Corte sobre o processo. ${ }^{63}$

\footnotetext{
${ }^{61}$ O PL e o parecer da Comissão podem ser obtidos pelo site do Senado, pelo endereço eletrônico: http://www.senado.gov.br/atividade/materia/detalhes.asp?p_cod_mate=113220. Último acesso em 26 de março de 2015.

${ }^{62} \mathrm{O}$ parecer do senador João Capibaribe pode ser obtido pelo seguinte endereço do Senado: http://legis.senado.leg.br/mateweb/arquivos/mate-pdf/148362.pdf. Último acesso em 28 de março de 2015.

${ }^{63}$ Outras razões para esta expectativa estão no fato de que a mudança de entendimento sobre a matéria que afetou parte considerável da comunidade jurídica, a começar pela própria $\mathrm{OAB}$, passando pelo Ministério Público, pela Procuradoria Geral da República e por alguns magistrados e desembargadores federais, tem repercutido também na forma como a opinião pública enxerga a questão. Segundo pesquisa realizada pelo Datafolha, e publicada em março de $2014,46 \%$ da população brasileira estaria a favor da anulação da Lei de Anistia tal como aplicada atualmente, contra $37 \%$ favoráveis à manutenção de seus contornos (outros $17 \%$ não sabem dizer). A mesma pesquisa identificou que $46 \%$ defende a punição a torturadores, contra $41 \%$. Em 2010, a situação era praticamente inversa, $45 \%$ era contra punições de torturadores e $41 \%$ a favor.

Por outro lado, também sobressai no resultado da pesquisa mais recente a resposta para a pergunta sobre se tanto agentes da repressão quanto guerrilheiros políticos deveriam ser punidos pelos crimes praticados: $80 \%$ entende que sim. É preciso levar em conta, contudo, que pelo menos parte deste resultado expressivo pode estar associado a um inconformismo mais geral contra a impunidade no país. A própria Folha faz a ressalva de que, na medida em que os opositores do regime já foram julgados ou penalizados com prisões, torturas, mortes, desaparecimentos, exonerações etc, a proposta de punição de opositores do regime não teria força política nem jurídica. Outro resultado expressivo da pesquisa e que destoa da abordagem geral da mídia em relação ao tema diz respeito ao programa de reparações: $52 \%$ concorda com as indenizações pagas a perseguidos políticos, $22 \%$ concorda em parte, $7 \%$ não sabe, $5 \%$ é indiferente, e apenas $14 \%$ discorda completamente ou em parte. Vide a reportagem MENDONÇA, R. "Maior parte da população quer anular Lei da Anistia, aponta Datafolha”. Folha de São Paulo. São Paulo, 31 mar. 2014. Caderno Poder. Disponível em: http://www1.folha.uol.com.br/poder/2014/03/1433374-maior-parte-da-populacao-quer-anular-lei-daanistia-aponta-datafolha.shtml. Último acesso em 11 de março de 2015.
} 
Recentemente, o atual presidente do STF, Lewandowski, no discurso de abertura do ano Judiciário de 2015, sustentou que estão entre os nove objetivos centrais a serem buscados pelo Judiciário brasileiro no ano: "Aprimorar a interlocução do STF com organismos internacionais, tribunais supranacionais e cortes de outros países, objetivando fortalecer a proteção dos direitos fundamentais enquanto valores que integram 0 patrimônio comum da Humanidade." (Lewandowski, 2015, p. 08). ${ }^{64}$

Mas com relação especificamente ao julgamento dos embargos de declaração na ADPF 153, a possibilidade de mudança de posição no Supremo, ainda que real, é pequena. Os quatro novos ministros do STF são Luiz Fux, Rosa Weber, Teori Zavascki e Roberto Barroso. Dos que julgaram improcedente a ação da OAB em 2010, continuam outros quatro: Carmen Lúcia, Celso de Mello, Marco Aurélio Mello e Gilmar Mendes. E dos dois que haviam dado provimento parcial à ação permanece apenas Ricardo Lewandowski. Neste contexto, e lembrando que o ministro Dias Toffoli declarou-se impedido de participar do processo desde seu início, se todos os ministros que participaram do julgamento em 2010 mantiverem sua posição na futura decisão sobre os embargos de declaração, será preciso que todos os quatro novos ministros acompanhem o atual presidente, para que a ação da OAB possa ter sucesso. ${ }^{65}$ Já vimos, por exemplo, que em decisão preliminar monocrática, o ministro Teori Zavascki resolveu suspender a ação penal do caso Rubens Paiva. ${ }^{66}$

\footnotetext{
${ }^{64} \mathrm{O}$ mencionado discurso, disponibilizado pelo STF, pode ser encontrado no seguinte link: http://www.stf.jus.br/arquivo/cms/noticiaNoticiaStf/anexo/ABERTURA_DO_ANO_JUDICIARIO_DE_201 5.pdf. Último acesso em 26 de março de 2015. Já em fevereiro de 2015, na qualidade também de presidente do Conselho Nacional de Justiça (CNJ), o ministro Lewandowski recebeu uma delegação de comissários da Comissão Interamericana de Direitos Humanos, com sua presidente e seu secretário-geral, e assinou carta conjunta de intenções. Um dos pontos centrais da carta prevê a realização de cursos de formação e capacitação de magistrados e funcionários em direitos humanos, bem como a disponibilização de bibliografia eletrônica pelo site do CNJ sobre a matéria. A carta também dispõe sobre a publicação de outras obras com compêndios de tratados internacionais e com a jurisprudência da Corte Interamericana sobre a área. Vide notícia do próprio CNJ, disponível em: http://www.cnj.jus.br/noticias/cnj/30675:cnj-assina-nestasemana-documento-inedito-com-cidh. Último acesso em 26 de março de 2015.

${ }^{65}$ Se for indicado o décimo primeiro ministro até lá, também seria preciso que este aderisse à mudança.

${ }^{66}$ Por outro lado, esta decisão monocrática, além de ser preliminar, pode representar apenas uma questão de coerência institucional por parte do ministro, uma vez que a última posição da Suprema Corte a respeito do tema foi assentada no julgamento de 2010 e os embargos de declaração ainda não foram julgados.
} 


\section{Considerações finais do capitulo}

Com relação à ADPF 153, importa frisar em primeiro lugar que a Ementa do acórdão não retrata bem o conjunto dos votos que julgaram a ação improcedente. $\mathrm{Na}$ verdade, ela reproduz essencialmente trechos do voto do relator Eros Grau e entendimentos desenvolvidos por Gilmar Mendes. O status "constituinte" da EC 26/1985, por exemplo, foi aventado apenas pelos dois e expressamente afastado, como vimos, pelos ministros Carmem Lúcia (que na parte dispositiva do acórdão acompanhou o relator) e Ayres Britto (voto vencido). Os demais ministros não abordaram o tema em seus votos.

Parte deste problema está associada ao fato de que, na ADPF e em outros tipos de ação, o relator fica responsável pela redação da Ementa, que representa a decisão colegiada, institucional, portanto. Outra parte está relacionada ao fato de que cada ministro profere um voto individual, na maioria das vezes bastante longo e previamente redigido (sobretudo no controle de constitucionalidade), sem haver propriamente uma deliberação a respeito do tema. Em artigo com título bastante sugestivo neste sentido ("Deciding without deliberating"), Virgílio Afonso da Silva (2013) compara o mecanismo de aglutinação dos votos do STF com outras Cortes Constitucionais, como a alemã e a francesa, e mostra que, na Corte brasileira, as Ementas em geral ou reproduzem o entendimento deum voto vencedor ou constituem um recorte às vezes pouco inteligível de diferentes votos. Além disso, com a hiper-exposição do STF pela TV Justiça, mediante a transmissão ao vivo dos julgamentos, especialmente nos mais polêmicos, como no caso da ADPF 153, os ministros tentam formular manifestações que poderiam marcar suas carreiras, de modo que mudar de posição neste contexto se tornaria algo constrangedor e improvável por parte dos ministros.

Além disso, é importante destacar mais uma vez aqui a parca consideração da normativa e da jurisprudência de Cortes internacionais mesmo pelos votos divergentes. Com relação à imprescritibilidade dos crimes de lesa-humanidade, reconhecida como costume internacional já antes da ditadura militar no Brasil, Ismael Moraes (2013) chama atenção para o fato de que nenhum dos ministros retomou precedentes do próprio STF, que tem admitido o caráter obrigatório do direito consuetudinário internacional em alguns casos, como ocorre com a imunidade de jurisdição de Estado estrangeiro, que não é prevista expressamente na Convenção de Viena. 
A maioria dos ministros também não realizou o chamado "controle de convencionalidade" no julgamento da ADPF 153 pelo Supremo. A respeito do controle de convencionalidade, conforme expõem Luiz Flávio Gomes e Valério Mazzuoli (2011), o STF adota a tese dualista, com predominância do direito constitucional (interno) sobre o direito internacional. Os tratados internacionais equivalem, na pirâmide normativa do direito brasileiro, às leis ordinárias, salvo aqueles sobre direitos humanos, que possuem hierarquia supralegal, mas infraconstitucional. ${ }^{67}$ Apenas se o STF adotasse a tese do status constitucional dos tratados em direitos humanos assinados pelo Brasil - que é defendida por alguns juristas respeitáveis, como os próprios Luiz Flávio Gomes e Valério Mazzuoli (2011) e Flávia Piovesan (2007), ou pelo ministro Celso de Mello (no Recurso Extraordinário 466.343) - seria possível colocar o controle de convencionalidade no centro da discussão de um caso que, como a ADPF, trata de um controle concentrado de constitucionalidade. ${ }^{68}$

Como vimos acima, Celso de Mello foi o único Ministro do STF que analisou a validade da Lei de Anistia em face dos Tratados Internacionais sobre direitos humanos, cuidando, inclusive, de julgamentos proferidos pela CrIDH. Assim o fez para afastar o caráter de autoanistia e os precedentes da referida corte internacional nos casos "Barrios Altos", "Loayaza Tamayo" e "Almonacid Arellano". Para ele, diferentemente de em outros casos, a Lei de Anistia no Brasil teria sido resultado de amplo debate e negociação, além de ser bilateral e não favorecer apenas os agentes da repressão. ${ }^{69}$

De forma parecida com Celso de Mello, Cezar Peluso e Gilmar Mendes também teceram comentários acerca da chamada "teoria dos dois demônios" para justificar a bilateralidade da lei, pois em sua visão tanto agentes da repressão quanto militantes armados teriam cometido graves violações aos direitos humanos. Nas palavras de Gilmar Mendes (2010, p. 239): "Não é possível conferir a ilicitude criminal a alguns atos e, ao

\footnotetext{
${ }^{67}$ Este entendimento foi assentado nos Recursos Extraordinários 466.343 e 349.703 e nos Habeas Corpus 87.585 e 92.566 .

${ }^{68}$ Importa ressaltar, contudo, que desde a aprovação da Emenda Constitucional 45/2004, os Tratados Internacionais sobre direitos humanos aprovados por três quintos, em dois turnos, nas duas Casas Legislativas do Congresso Nacional, passam a ser considerados como equivalentes às Emendas Constitucionais. Seguindo este procedimento, pelo menos até meados de 2013, havia sido aprovado apenas o texto da Convenção Internacional sobre os Direitos das Pessoas com Deficiência e seu Protocolo Facultativo.

${ }^{69}$ Também rejeitou a imprescritibilidade dos crimes objeto da ADPF 153, tendo em vista o princípio da reserva legal, considerando que o Brasil não aderiu à Convenção sobre Imprescritibilidade dos Crimes de Guerra e dos Crimes contra a Humanidade, impedindo a aplicação do costume internacional como fonte do direito penal.
} 
mesmo tempo, reconhecer que outros de igual repercussão possuem natureza distinta e podem ser justificados em razão do objetivo político ideológico que os geraram".

$\mathrm{O}$ ministro realizou assim uma operação em que equivale as violências praticadas de parte a parte, desconsiderando as diferenças políticas cruciais que as distinguem, além da diferença de extensão e proporção também dos crimes. De um lado tratava-se de violências praticadas sob os auspícios de uma organização de Estado e de uma política de Estado que produziam, assim, um ambiente de dominação política pela força, pela ameaça e, no que servia, pelo legalismo autoritário. De outra parte, como já foi comentado no capítulo anterior, é bem verdade que a maioria dos grupos guerrilheiros não era propriamente democrática, mas constituiu de fato uma resistência ao poder político que exercia a dominação. ${ }^{70}$

Esta diferença é absolutamente crucial. De fato, tivesse havido uma revolução socialista ou coisa do gênero no país (algo de que sempre estivemos muito longe, mesmo no começo da década de 1960, como atesta a literatura a respeito), poderia ter se constituído uma dominação e um autoritarismo por parte dos movimentos de esquerda. Mas não foi o que ocorreu. A dominação foi erguida pelos militares que tomaram o poder e dirigiram o país associados a boa parte da burguesia industrial e da antiga elite agrária. ${ }^{71}$

\footnotetext{
${ }^{70}$ Como foi comentado no capítulo anterior, a luta armada ergueu-se fundamentalmente após o golpe de 1964 e como resultado de uma avaliação crítica por parte sobretudo de dissidências do PCB a respeito da conveniência do antigo empenho do partido no sentido de aprofundar as contradições do capitalismo antes de combatê-lo pela via revolucionária, o que significava atuar dentro da legalidade. Com isso, o fenômeno da luta armada no Brasil foi essencialmente resultado de uma reação ao golpe de 1964 e da instauração da ditadura civil-militar. Importantes exceções à constituição de movimentos guerrilheiros apenas depois do golpe dizem respeito a grupos associados a sindicatos rurais ligados às Ligas Camponesas e ao PCB, que se armavam pelo menos desde o início da década de 1960 em função da dinâmica própria da luta fundiária no país (Cf. Bastos, 1984). Mesmo a Guerrilha do Araguaia contava antes de 1964 com apenas um militante no local onde viria a se instalar o grupo mais tarde. Todos os demais integrantes só se mudaram para a região da guerrilha a partir de 1967 (Cf. Ridenti, 1993).

${ }^{71}$ A literatura a respeito das razões do golpe de 1964 é bastante ampla e tem sido objeto de variadas abordagens. Grosso modo, porém, poderíamos dividir estas abordagens em duas grandes correntes: uma que trata de causas mais relacionadas à conjuntura política do início dos anos 1960 e ao poder de "agência" dos atores políticos então envolvidos, como, por exemplo, Alfred Stepan (1971), René Dreifuss (1981), Maria do Carmo Campello de Souza (1983), Lúcia Hipólito (1985), Wanderley Guilherme dos Santos (1986) e Argelina Figueiredo (1993). E outra que se reporta a questões de fundo econômico-social e de classe nos fundamentos para o rompimento da lealdade das elites brasileiras à ordem democrática. Entre os autores que poderiam ser reunidos neste enfoque mais amplo estão, por exemplo, Francisco Weffort (1978), Guillermo O’Donnell (1987), Florestan Fernandes (2006) e Luiz Alberto Moniz Bandeira (2001). Esta divisão que faço aqui da literatura é sensivelmente diversa da elaborada por Argelina Figueiredo (1993), pois em sua interpretação, por exemplo, entre os autores que atribuiriam o golpe a causas "estruturais" estaria Wanderley Guilherme dos Santos (1986), o qual, entretanto, acentua bastante a inabilidade do então presidente João Goulart em lidar com a crise que se erguia diante de seu governo, de modo que, para ele, a questão da "agência" (ou da falta dela) parecia ser pelo menos tão ou mais determinante para o golpe quanto outras razões de fundo "estrutural". Seja como for, as duas vertentes, embora uma ressalte mais a dimensão da "agência" e a outra mais a da "estrutura", não são necessariamente excludentes e podem ser lidas, grosso modo, como complementares. Além disso, nenhum destes autores leva a sério a existência na época de uma possibilidade real de revolução socialista. A chamada "ameaça vermelha" foi, na verdade, efetiva apenas no
} 
Uma interpretação que não enxerga esta diferença comete o grave erro político de não discernir dominação de resistência, equivalendo-as. Ademais, a equiparação entre uma e outra é colocada de modo tal por Gilmar Mendes como se fossem comparáveis a extensão e o grau de violência que a repressão e a luta armada praticaram.

Além disso, um dos principais argumentos da Ementa da decisão do STF em comento sustenta, como dito acima, que a Lei de Anistia foi criada pelo Congresso Nacional e que não caberia à Suprema Corte alterá-la. ${ }^{72}$ Cumpre ressaltar, entretanto, que a votação por maioria no Congresso não impediu que a Corte declarasse como inconstitucionais uma série de outras leis, boa parte delas, aliás, votadas pelo Congresso do atual período democrático.

Por isso, na lógica desta argumentação do STF, uma maioria legislativa produzida durante o regime militar parece ter primazia sobre outras maiorias legislativas produzidas sob um regime democrático. Além disso, esta argumentação é também um tiro no pé do próprio ativismo do STF na revisão judicial, verificado pela literatura nos últimos anos, uma vez que a existência do controle de constitucionalidade pressupõe logicamente que o critério da maioria não é suficiente para a constitucionalidade ou legitimidade de uma lei. Se o critério da maioria fosse suficiente, a revisão judicial não seria, ela mesma, legítima. $^{73}$

A fim de aprofundarmos uma avaliação crítica dos principais argumentos e fundamentos desta decisão do STF, penso que nos podem ser úteis questões como a cooriginalidade entre soberania popular e direitos humanos e a universalidade dos princípios

\footnotetext{
nível do discurso de setores mais conservadores ou reacionários que ajudaram a incendiar a polarização na cena pública na época.

${ }^{72}$ Embora a Ementa aqui discutida não represente muito bem a maioria dos votos vencedores, como vimos, de todo modo ela consubstancia a posição institucional do STF sobre a questão.

${ }^{73}$ À revelia desta argumentação desenvolvida nesta decisão, o STF é o mesmo Tribunal que exercita amplamente sua função legislativa anômala a propósito do controle de constitucionalidade das leis e mesmo em outros instrumentos processuais, atuando não apenas de forma negativa (declarando inconstitucionalidades), mas suprindo omissões legislativas. Recentemente, aliás, o STF não teve problemas para considerar inconstitucional a Lei de Imprensa, publicada também durante a ditadura. A Corte entendeu esta lei como incompatível com a nova ordem constitucional. Arantes (2005) e Taylor (2008) apontam vários números acerca da judicialização da política no Brasil. O caso brasileiro é notório porque o país tem uma das maiores Cartas Constitucionais do mundo (em termos de dispositivos) e um sistema híbrido de revisão judicial. Aliás, a legitimidade ativa para a propositura de ações de revisão judicial é uma das mais amplas do mundo, senão a mais ampla (Arantes, 2005, p. 238). Assim como Stone Sweet escreveu em relação à atuação do Judiciário nos países do continente europeu, Taylor (2008, p. 27) salienta que o Judiciário brasileiro desempenha importante papel na configuração final das políticas públicas por aqui. De forma semelhante, Arantes (2005, p. 250) assevera que o Judiciário passou a disputar com o governo federal a primazia do paternalismo político sobre a sociedade brasileira.
} 
versus a particularidade dos valores na interpretação da lei, que são discutidos por Habermas em alguns de seus textos. ${ }^{74}$

Na visão do filósofo alemão, o desenvolvimento e a cristalização do Estado Social, que encara a política de forma instrumental e intervencionista, teria ganhado também a auto-compreensão da revisão judicial mundo afora. Na qualidade de substitutos do legislador, os Tribunais Constitucionais carregam cada vez mais a instrumentalidade da política para o âmbito das decisões jurídicas (Cf. Habermas, 2003c, p. 269).

$\mathrm{Na}$ tendência dessa politização das questões jurídicas na Corte Constitucional brasileira, a decisão na ADPF 153 calcou um de seus argumentos centrais na peculiaridade histórica da transição e da anistia no Brasil, que teriam erigido o caminho da "conciliação nacional", da qual o caráter "bilateral" da anistia seria o principal corolário. Tendo selado o pacto que deitou as bases sobre as quais se ergueu o novo regime democrático, e derivada de amplo "clamor nacional", esta característica bilateral da anistia seria irrevogável, intocável por qualquer ator social.

Mas a justiça, embora mediada pela cultura e pela história de uma sociedade, deve remeter sempre a um critério universal. Se a política diz respeito à formação pública da opinião e da vontade entre cidadãos livres e iguais em uma dada comunidade, em última análise, a justiça não se subordina à formação da opinião e da vontade. Isto porque ela não se confunde com a política, não é uma questão de alcance do bem comum de uma determinada comunidade, mas envolve, primordialmente, uma consideração universal de todos os homens, de todas as comunidades, e por isso tem uma dimensão não particularizável, não negociável, mas obrigatória, cogente. ${ }^{75} \mathrm{O}$ terror jacobino e o nazismo, mesmo que (pelo menos a princípio) politicamente apoiados pela maioria, não poderiam ser considerados como justos.

Justiça e política se comunicam constantemente, inclusive uma alimentando o desenvolvimento da outra, mas em última análise elas são epistemologicamente distintas:

\footnotetext{
${ }^{74}$ Para uma discussão mais aprofundada sobre os pressupostos teóricos destes temas na obra de Habermas, ver meu texto mencionado na nota 7.

${ }^{75}$ Para Rainer Forst (2011), Habermas possui uma teoria do direito, mas não exatamente uma teoria da justiça, uma carência que Forst procura suplantar no âmbito da Teoria Crítica. Entretanto, embora não seja o caso aqui de desenrolar uma argumentação mais detalhada a respeito, o que também poderia por si só render pelo menos outro capítulo, vale dizer que, reconhecendo-se em alguma medida como pertencente a uma das gerações da Teoria Crítica, Habermas distancia-se, em sua teoria do direito, de uma visão simplesmente formal ou pura do direito e o conecta a uma noção universal do que seja o justo. Em Faktizität und Geltung, ao dizer que a "moral" faz a pergunta pelo "justo" (em oposição à "ética", que faz a pergunta pelo socialmente desejável em determinadas circunstâncias), Habermas associa o direito à categoria do "justo", e remete ambos a um ponto de vista universal.
} 
a primeira é deontológica; a segunda, teleológica. ${ }^{76}$ Uma argumentação a respeito do que seria melhor para a sociedade brasileira ao mesmo tempo em que afasta reivindicações de uma justiça com aspirações universais não discerne tal distinção.

Além disso, as posições da AGU em sede dos embargos de declaração na ADPF 153 e algumas declarações de ministros do STF após a sentença da CrIDH no caso Guerrilha do Araguaia sobre esta desafiar a soberania nacional também seriam incongruentes sob o ponto de vista que ora discutimos. Pois elas não discernem a cooriginalidade e a interdependência entre direitos humanos e soberania. $\mathrm{Na}$ visão de Habermas (2003c), a soberania que viola os direitos humanos é ilegítima. A incomunicabilidade entre a decisão do STF e as manifestações da AGU, de um lado, e a decisão da $\mathrm{CrIDH}$, de outro, sustenta-se em visões diferentes sobre o direito: os primeiros têm uma visão ainda ligada aos limites do Estado Nação; já a segunda procura forjar uma concepção universalista do direito.

Esta perspectiva ainda essencialmente "doméstica" ou "westfaliana" do direito também se associa a uma hermenêutica mais pautada em critérios "ético-valorativos" do que em "princípios" na interpretação dos direitos fundamentais. Na visão de Habermas (2003b), como já mencionado, a "ética" diz respeito ao conjunto de valores compartilhados por uma comunidade em determinadas circunstâncias; já os "princípios" se referemà dimensão do "justo", que é universalizável. Os votos do relator e de outros ministros que o acompanharam são profusos em mostrar a inclinação da Corte neste sentido: a caracterização da Lei de Anistia como uma "lei-medida" que dá ensejo à conceituação sui generis da expressão "crimes conexos" no bojo da referida lei talvez seja o exemplo mais forte a este respeito.

Em outras palavras, é uma certa interpretação (bastante disputada, aliás) sobre o processo de redemocratização do país, entendido como "conciliado" e como tendo tomado corpo na anistia de 1979, que sustentaria uma interpretação particular ("sui generis")do conceito de crimes conexos no bojo da lei. E esta argumentação baseada em uma interpretação histórica (sobre o processo de transição "conciliado") e sociológica (sobre a adequação deste processo à sociabilidade brasileira) é justamente a pedra de toque do voto do relator (e também do ministro Gilmar Mendes), que serviu de base para a Ementa. Sem este ensaio de interpretação não haveria como encetar a conceituação peculiar de crimes conexos no bojo daquela lei e, por extensão, aproveitar os efeitos de isenção de

\footnotetext{
${ }^{76}$ A este respeito, cf. Habermas (2003b, pp. 314 e seguintes).
} 
responsabilidade penal também a agentes públicos que violaram direitos humanos durante a ditadura civil-militar no país.

Onde a visão metodológica sobre os direitos fundamentais se volta para um discurso ético-valorativo, os objetivos da decisão judicial visam a encontrar aquilo que é considerado como melhor para os cidadãos, no horizonte de sua forma de vida e de seu contexto. ${ }^{77}$ A Ementa do referido julgamento do STF diz: “É a realidade histórico-social da migração da ditadura para a democracia política, da transição conciliada de 1979, que há de ser ponderada para que possamos discernir o significado da expressão crimes conexos na Lei n. 6.683".

É justamente por isso que a anistia brasileira manteve seu caráter bilateral no julgamento em comento, pois ela é considerada como o momento da reconciliação fundadora que teria possibilitado o retorno do regime democrático, e por isso teria uma primazia ética sobre todo o ordenamento jurídico válido no novo regime, pois ela - mais do que o integra - seria sua condição de possibilidade. Eticamente, nesta perspectiva, seríamos a nação da (re)conciliação.

Pode-se até contestar a validade efetivamente universal dos direitos humanos e mesmo a interpretação realizada pela $\mathrm{CrIDH}^{78}$, mas o problema da argumentação do STF reside no fato de que não houve sequer um esforço (por parte do relator e da maioria dos ministros que acompanharam seu voto) de aplicação de uma justiça com sentido universal. Nesta perspectiva, o direito atinente à anistia passa a valer como um direito "à brasileira". ${ }^{79}$ Para o STF, sendo a Lei de Anistia uma "lei-medida", que precisa ser interpretada na peculiaridade histórica de sua elaboração, ela diz respeito a uma experiência brasileira, e neste sentido não poderia ser tratada pelo direito internacional, surdo às razões políticas, culturais e sociais de sua existência.

O auto-entendimento ético-político faz parte do processo deliberativo na esfera pública. Ali os participantes desejam obter clareza sobre sua condição de membros de determinada nação, que tradições estão cultivando, como se tratam, como tratam as minorias. Contudo, tanto a normatização das regras de convivência quanto a aplicação do direito devem estar primariamente norteadas pelo ponto de vista da justiça, que é universal, e não está adstrita à forma de vida de uma comunidade concreta. Nas palavras de Habermas: "o direito de uma comunidade jurídica concreta, normatizado politicamente,

\footnotetext{
${ }^{77}$ A este respeito, cf. também Habermas (2003b, p. 349).

${ }^{78}$ Uma crítica a respeito da jurisprudência da CrIDH pode ser lida no final do capítulo 1 .

${ }^{79}$ Mais detalhes sobre o "provincianismo jurídico" desta e de outras decisões do STF podem ser encontrados em Deisy Ventura (2011).
} 
tem que estar, ao menos, em sintonia com princípios morais que pretendem validade geral, ultrapassando a própria comunidade jurídica" (Habermas, 2003b, pp. 350 e 351). E mais adiante: "o procedimento democrático não pode mais extrair sua força legitimadora do acordo prévio de uma comunidade ética pressuposta, e sim de si mesmo" (Habermas, 2003b, p. 354).

Como ressalta Almeida (2008, p. 510), se a visão ética do direito for a concepção defendida pelo Tribunal Constitucional, isso implica um risco para o pluralismo, na medida em que qualquer outra concepção política também pautada pelo ideal de razão pública pode ser excluída aprioristicamente do debate.

A "anistia recíproca", tida numa perspectiva que a interpreta como o pacto de "reconciliação nacional" que teria permitido o retorno democrático no país, é encarada ainda hoje como intocável. Mais do que os efeitos negativos, como destaca a literatura, sobre a consolidação dos direitos civis por aqui em função da impunidade de agentes do Estado e das Forças Armadas ${ }^{80}$, a sedimentação de uma tal imagem parece se apresentar como um limite à força das instituições do Estado brasileiro na condução ou na alteração dos rumos de nossa justiça de transição.

\footnotetext{
${ }^{80}$ Flávia Piovesan (2010, p. 105), por exemplo, pondera que a impunidade de agentes da repressão no Brasil pode ser responsável, pelo menos em parte, pela prática ainda contínua da tortura. A tortura ainda seria generalizada e sistemática, mas a lei que regula seu processo (Lei 9.455/1997) quase não foi aplicada ainda. Além disso, Kathryn Sikkink e Carrie Walling (2010) afirmam que, na avaliação da escala PTS (Political Terror Scale - aferida pela Anistia Internacional em conjunto com o Departamento de Estado norteamericano), o Brasil piorou em relação ao período ditatorial. Isso significaria que a democracia, por si só, não garante a melhora nos direitos humanos básicos. Por outro lado, a grande maioria dos países que realizaram julgamentos de agentes públicos que violaram direitos humanos em um passado de guerra civil ou ditadura melhorou significativamente na escala. As autoras apontam, neste sentido, que países com mesmo nível de democracia (de acordo com o índice da Freedom House Political Rights) têm níveis de violações de direitos humanos diferentes. Brasil, Argentina, Peru, México e El Salvador tinham atribuído, até 2007, o mesmo índice democrático. Mas apenas o Brasil destoava deste grupo na escala de terror, com um resultado muito mais grave do que os demais. Talvez não por acaso, o Brasil seja o único destes países que não julgou agentes da repressão política. Para fechar o argumento, Sikkink e Walling mostram que, de outro lado, por exemplo, a Guatemala, com nível democrático bem pior do que o brasileiro, julgou muitos de seus antigos agentes ditatoriais, e apresenta hoje um baixo índice de violação de direitos humanos. Se as autoras não podem ainda, no estágio de sua pesquisa, fazer peremptoriamente a afirmação de que o julgamento e a condenação de violadores de direitos humanos ajuda a melhorar a proteção dos direitos civis, elas pelo menos afastam a ideia (muito presente em autores da transitologia, como vimos em passagens dos capítulos 1 e 2) de que os julgamentos ameaçariam a democracia, o império da lei e os próprios direitos humanos.
} 


\section{Capítulo 4. A Comissão Nacional da Verdade}

Neste capítulo, tentarei traçar em linhas gerais o processo de instalação, as atividades e o relatório final da Comissão Nacional da Verdade brasileira. No Brasil, desde o fim da ditadura militar, usualmente identificado no ano de 1985, até o fim da década de 2000, nenhuma comissão da verdade estatal havia sido criada, diferentemente do que ocorreu na grande maioria dos demais países da América Latina que atravessaram por um período de autoritarismo e violações sistemáticas a direitos humanos em um passado recente. Como vimos no capítulo 1, no mesmo ano identificado como o fim da ditadura, a arquidiocese de São Paulo publicou o relatório Brasil: nunca mais, até meados dos anos 2000, o relato mais completo sobre torturas no país. Tratava-se, porém, de um trabalho produzido por uma organização da sociedade civil.

Desde instituições do Estado, como vimos no capítulo 2, apenas a partir de 2007 o Brasil passaria a produzir relatórios neste sentido, primeiramente com o detalhamento de circunstâncias de morte e desaparecimento de perseguidos políticos em função da atuação estatal. Entretanto, os livros produzidos pela Comissão Especial sobre Mortos e Desaparecidos Políticos (CEMDP) e pela Comissão de Anistia não seriam resultado de um processo primordialmente voltado à elucidação da "verdade", pois esta viria a reboque de processos administrativos, na maioria das vezes reservados, de concessão de reparações econômicas. Por isso que, entre outras coisas, além de produzir um relatório mais completo sobre as violações do que aqueles que as comissões de reparação puderam produzir até então, a CNV teria o objetivo também de colocar o processo de elucidação da verdade no centro de suas atividades, de modo a galgar o tema entre os mais debatidos na 
agenda pública nacional. A interação com a sociedade civil e o destaque para os testemunhos e para a voz das vítimas também seriam diferenciais importantes a pautar seus trabalhos.

As comissões da verdade estão situadas numa posição de interlocução entre sociedade civil e Estado, o que, em alguma medida, já de saída marca sua atuação com o signo da ambiguidade. De um lado, como vimos no capítulo 1, estas comissões têm entre suas principais funções resgatar e redimir histórias e narrativas antes silenciadas. E estas histórias e narrativas antes silenciadas são, na maioria das vezes, as histórias e narrativas das vítimas da repressão política. É neste sentido que, mais do que a revelar "verdades" e preservar "memórias", as comissões da verdade são avaliadas também por sua capacidade de colocar as vozes das vítimas no centro de suas atividades. Ao mesmo tempo, estas comissões também precisam dar uma resposta institucional no nível do Estado para suas tarefas, o que, entre outras coisas, implica que sua atuação será pautada pelos parâmetros da estrita legalidade da Administração Pública. Em outras palavras, a não ser em termos de sugestões de mudanças na qualidade de recomendações, sua atuação será pautada pelos limites e possibilidades estritos do ordenamento jurídico em vigor. ${ }^{1}$

A CNV foi instalada, realizou suas atividades e especialmente publicou seu relatório final muito recentemente. Este último foi apresentado no dia 10 de dezembro de 2014, pouco mais de quatro meses antes da finalização desta tese e do início de sua revisão. Até este momento, praticamente não há literatura especializada ainda sobre o relatório final da Comissão. A maioria dos textos da parca literatura ${ }^{2}$ sobre a $\mathrm{CNV}$ tem foco no seu processo legislativo e de implementação, que ocorreu basicamente entre 2009 (quando foi publicado o PNDH-3 ${ }^{3}$ ) e 2012, quando a CNV foi finalmente instalada. ${ }^{4}$ Isto porque o processo legislativo e a implementação da Comissão tomaram lugar em tempo já um pouco mais distante e passível, portanto, de considerações mais detidas.

Além da parca literatura a respeito das atividades da CNV e de seu relatório final,

\footnotetext{
${ }^{1}$ É neste sentido que, entre outras coisas, por exemplo, uma tal comissão jamais poderia assumir caráter jurisdicional ou persecutório no ordenamento jurídico brasileiro, ainda que a demanda por "justiça" tenha sido uma das esperanças associadas à criação da comissão da verdade por alguns grupos da sociedade civil atuantes na área.

${ }^{2}$ Se comparada àquela produzida a respeito das comissões de reparação e da jurisprudência de tribunais brasileiros em matéria de justiça de transição.

${ }^{3}$ O Plano Nacional de Direitos Humanos 3.

${ }^{4}$ Sobre o período que vai do PNDH-3 à instalação da CNV, cf. artigos sobre a Comissão nos livros organizados por Flávia Piovesan e Inês Soares (2014) e por Emílio Peluso Meyer e Marcelo Cattoni de Oliveira (2014), bem como os relatórios parciais de acompanhamento feitos pelo Instituto de Estudos da Religião (ISER, 2012, 2013a, 2013b e 2014). Depois da publicação do relatório final da CNV, o que há de mais completo na literatura especializada é o quinto e último relatório de acompanhamento do ISER (2015) sobre as atividades da $\mathrm{CNV}$, incluindo uma avaliação sobre seu relatório final.
} 
este último pretendeu-se explicitamente descritivo e não analítico, a fim de focar o empenho narrativo da Comissão na reconstrução dos casos de violações aos direitos humanos que puderam ser apurados, bem como na estrutura da repressão, no engajamento da sociedade civil na oposição, entre outros temas. Mesmo com o enfoque descritivo, o relatório final da Comissão conta com mais de 4 mil páginas, que foram necessárias para que se pudesse traçar uma reconstrução mais detalhada e completa possível de seu objeto.

Por assumidamente não conter um enfoque analítico, contudo, o relatório final carece, por exemplo, de uma "interpretação" sobre a redemocratização no Brasil. Entretanto, pela via das recomendações, pode-se extrair uma clara visão assumida pela instituição acerca das potencialidades e rumos que a justiça de transição deve desenvolver futuramente no país. Além de discutir este aspecto, que nos é central para o escopo da tese, a ideia será recuperar aqui alguns dos procedimentos adotados pela CNV no curso de suas atividades e alguns dos "resultados" obtidos, pois assim poderemos avaliar, ainda que a título um tanto preliminar, o quão inclusivo e/ou coerente com seus próprios desígnios e potencialidades foi este processo. Nos termos do quinto relatório de acompanhamento do ISER sobre as atividades da CNV: "Mais que 'reconstruir a história', a forma como este processo aconteceu também entrará para a história do país" (ISER, 2015, p. 14). ${ }^{5}$

\section{1) Do PNDH-3 ao funcionamento da CNV}

O chamado direito à verdade passou a ser objeto de atenção especial da ONU a partir de 2006, quando o Alto Comissariado para Direitos Humanos publicou o Estudo sobre o direito à verdade, segundo o qual o dito direito consistiria na revelação da "íntegra e completa verdade" sobre as raízes das violações aos direitos humanos, dos resultados e procedimentos das investigações, das circunstâncias que possibilitaram as violações e da identificação dos violadores (Cf. Comisión de Derechos Humanos de las

\footnotetext{
${ }^{5}$ Importa destacar mais uma vez aqui, como o fizemos nos demais capítulos, que a opção por um ponto de vista em que as instituições do Estado têm centralidade na narrativa desta tese decorre de seu objeto, que são discursos promovidos por instituições estatais sobre o processo de redemocratização, sua visão sobre o papel da conciliação e da anistia neste processo e sua visão sobre os próprios limites e possibilidades da justiça de transição no país. A atuação e as reações da sociedade civil, embora reconhecidas como absolutamente centrais para o desenvolvimento da justiça de transição por aqui, aparecerão mais uma vez de forma secundária, como já ressaltamos, por uma questão de recorte de pesquisa.
} 
Naciones Unidas, 2006). ${ }^{6}$ Também segundo o Estudo da ONU, o direito à verdade teria basicamente duas dimensões: a individual, que obriga o Estado a disponibilizar informações específicas sobre as circunstâncias das graves violações que cada vítima sofreu no passado e, na hipótese de morte e desaparecimento, a localização dos restos mortais; e a coletiva, que obriga o Estado a apresentar informações sobre as circunstâncias que possibilitaram uma situação em que os direitos humanos passaram a ser sistematicamente violados.

Como vimos no capítulo 1, pelo menos desde o caso Velásquez-Rodrigues versus Honduras, julgado em 1988, a Corte Interamericana de Direitos Humanos (CrIDH) tem reconhecido o dever dos Estados signatários do Pacto de São José da Costa Rica (a Convenção Americana de Direitos Humanos) de investigar as graves violações ocorridas em período de autoritarismo e/ou guerra civil. E este dever, aliás, prescinde, no entendimento da Corte, de uma provocação judicial de eventuais ex-perseguidos ou familiares contra o Estado.

\subsection{1) O PNDH-3}

No final de 2009, a Secretaria de Direitos Humanos do governo federal, então sob a gestão do ministro Paulo Vannuchi, organizou a $11^{\text {a }}$ Conferência Nacional de Direitos Humanos, que contou com a participação de cerca de 1.200 delegados de comitês estaduais da área. O objetivo da conferência era revisar e editar o Programa Nacional de Direitos Humanos 3 (PNDH-3). Entre outras recomendações, a conferência terminou por encetar no plano a sugestão da criação de uma comissão da verdade para o país, a fim de proporcionar o esclarecimento e o debate público sobre as graves violações de direitos humanos ocorridas durante a ditadura militar no país. Na apresentação do Programa, o então presidente Lula ressaltou: "conhecendo inteiramente tudo o que se passou naquela fase lamentável de nossa vida republicana o Brasil construirá dispositivos seguros e um amplo compromisso consensual - entre todos os brasileiros - para que tais violações não se repitam nunca mais" (PNDH-3, 2010, p. 14) .

Pouco tempo depois, em janeiro de 2010, foi instituído pelo então presidente um grupo de trabalho que teria por objetivo elaborar o anteprojeto de lei para a criação da

\footnotetext{
${ }^{6} \mathrm{O}$ Estudo pode ser obtivo pelo seguinte endereço eletrônico: http://pfdc.pgr.mpf.mp.br/temas-deatuacao/direito-a-memoria-e-a-verdade/documentos-tecnicos-de-outrosorgaos/estudo_direito_a_verdade_ONU_09jan2006. Último acesso em 12 de maio de 2015.
} 
Comissão. O GT foi integrado pelo próprio Paulo Vannuchi, então secretário de Direitos Humanos da Presidência da República, Paulo Abrão, presidente da Comissão de Anistia, Marco Antônio Rodrigues Barbosa, então presidente da CEMDP, um consultor jurídico do Ministério da Defesa, o então professor de Ciência Política da USP Paulo Sérgio Pinheiro (na qualidade de representante da sociedade civil) e Erenice Guerra, então secretáriaexecutiva da Casa Civil, que presidiu o GT. O projeto de lei formulado pelo grupo foi encaminhado pela Presidência ao Congresso Nacional ainda em maio do mesmo ano.

Ainda em 2010, desde a sentença da Corte Interamericana condenando o Brasil no caso Araguaia $^{7}$, cresceu muito o número de grupos e entidades da sociedade civil engajados na chamada pauta da "memória, verdade e justiça", atinente aos desígnios normativos gerais da justiça de transição: a revelação das atrocidades cometidas durante o período de autoritarismo, a preservação de sua memória crítica, a reparação das violações cometidas contra perseguidos políticos e familiares e a responsabilização de perpetradores. Entre alguns destes grupos, podemos destacar o Coletivo Memória, Verdade e Justiça, o Coletivo Quem e os vários Comitês Estaduais pela Verdade, Memória e Justiça, que em geral reúnem diferentes organizações de esquerda em torno do tema. Estes grupos, muitas vezes associados com outras organizações de esquerda e com comissões de familiares de mortos e desaparecidos políticos, têm promovido, especialmente desde 2010, uma série de manifestações e atos públicos em defesa da responsabilização de pessoas envolvidas com o autoritarismo e com graves violações a direitos humanos. ${ }^{8}$

Ao lado da pressão da comunidade internacional consolidada pela sentença da Corte Interamericana e pelo desenvolvimento da agenda dentro do Estado brasileiro via CEMDP e Comissão de Anistia, a tenacidade da atuação destes grupos certamente contribuiu para constranger o governo brasileiro a acelerar o processo de criação de uma comissão da verdade e para tornar cada vez mais presente na agenda nacional a questão da responsabilização de agentes da repressão. Depois da sentença da $\mathrm{CrIDH}$ no caso Araguaia, o projeto de lei da Comissão da Verdade passaria a tramitar no Congresso Nacional, assim como ocorrera com a chamada Lei dos Desaparecidos (Lei 9.140/1995), sob o regime de urgência, restando pouquíssimo tempo para um debate ampliado a respeito do desenho da Comissão.

Os então ministros Rogério Sottilli, interino da Secretaria de Direitos Humanos,

\footnotetext{
${ }^{7}$ Detalhes sobre esta decisão e sua repercussão no país podem ser lidos no capítulo anterior.

${ }^{8}$ Entre as várias atividades organizadas por estes grupos estão protestos, seminários e escrachos públicos contra agentes da repressão.
} 
Nelson Jobim, da Defesa, Luiz Paulo Teles Ferreira Barreto, da Justiça, e Paulo Bernardo Silva, do Planejamento, que ficaram responsáveis pela elaboração da mensagem de encaminhamento do projeto de lei ao Congresso destacaram:

“A criação da Comissão Nacional da Verdade assegurará o resgate da memória e da verdade sobre as graves violações de direitos humanos ocorridas no período anteriormente mencionado [1946 a 1988], contribuindo para o preenchimento das lacunas existentes na história de nosso país em relação a esse período e, ao mesmo tempo, para o fortalecimento dos valores democráticos" (Sottili, Jobim, Barreto e Silva, 2010, § 17). ${ }^{9}$

Esta mensagem, além de conectar memória e história, verdade e democracia, também se referia à criação da CNV como resultado do acerto entre governo e sociedade civil via PNDH-3:

“A criação de uma Comissão Nacional da Verdade com o objetivo estratégico de promover a apuração e o esclarecimento público das graves violações de direitos humanos praticadas no Brasil no período fixado pelo artigo $8^{\circ}$ do Ato das Disposições Constitucionais Transitórias (ADCT) da constituição federal, em sintonia com uma das diretrizes constantes do $3^{\circ}$ Programa Nacional de Direitos Humanos (PNDH-3) publicado no final de 2009, responde a uma demanda história da sociedade brasileira" (ibid. id., $\S 1^{\circ}$ ).

A propósito do PNDH-3, foram realizados mais de 130 encontros prévios entre governo federal (via Secretaria de Direitos Humanos) e sociedade civil em todos os Estados e no Distrito Federal. No total, segundo o próprio governo (Cf. SEDH, 2010), cerca de 14 mil pessoas participaram dos encontros representando a sociedade civil ou o poder público. Entretanto, o projeto de lei apresentado pelo governo ao Congresso em 2010 não levaria em conta algumas das sugestões centrais do PNDH-3 para a configuração de uma comissão da verdade, dentre elas o foco no período de repressão política da ditadura militar (a lei aprovada estenderia o enfoque da Comissão entre 1946 e 1988).

Também é preciso dizer que, mais do que atender a demandas sociais, o timing da elaboração e publicação da lei não deixa dúvidas a respeito do fato de que o momento da instalação da CNV acabou por ser resultado, em boa medida, de uma das recomendações da CrIDH na sentença do caso Guerrilha do Araguaia. O constrangimento internacional em meio a um contexto em que o Judiciário do país continuava a persistir na impunidade

9 A mensagem pode ser lida no seguinte endereço eletrônico: http://www.planalto.gov.br/ccivil_03/projetos/EXPMOTIV/EMI/2010/14\%20\%20SDH\%20MD\%20MJ\%20MP.htm. Último acesso em 05 de maio de 2015. 
de agentes da repressão e em que outras decisões da CrIDH experimentavam uma compliance bastante resistida no Brasil terminou por ser o catalisador que faltava para que a Comissão fosse criada - e assim, dentre outras coisas, o Estado brasileiro pudesse galgar algo de sua reputação a respeito de compromissos internacionais em matéria de direitos humanos.

O trecho da mensagem de encaminhamento citado acima também não deixa dúvidas, como veremos com mais detalhe a seguir, de que a lei que criaria a Comissão seria pautados por um dos desígnios já tradicionalmente associados à anistia brasileira (expandida pelo ADCT da Constituição Federal de 1988), a (re)conciliação nacional.

\subsection{2) As Leis 12.527/2011 e 12.528/2011 e a instalação da CNV}

A lei que criou a $\mathrm{CNV}$, de número 12.528/2011, teve seu processo legislativo atrelado à tramitação da Lei 12.527/2011, a chamada Lei de Acesso à Informação, que passaria a restringir as hipóteses de classificação das informações de entidades do poder público e o prazo dos diferentes graus de sigilo. Isto porque, em boa medida, a efetividade e profundidade das investigações da CNV dependeriam da chamada desclassificação do sigilo de muitos documentos produzidos especialmente pelas forças de segurança durante o regime militar. $\mathrm{O}$ dispositivo da Lei de Acesso à Informação que veda a restrição de acesso a documentos dando conta de violações aos direitos humanos seria uma das bases legais para os ofícios e requerimentos da $\mathrm{CNV}$ dirigidos às Forças Armadas e ao Ministério da Defesa. Além disso, com relação a uma disponibilização mais ampla de documentos sobre o período ditatorial, a partir de 2005, por determinação presidencial, já haviam sido transferidas ao Arquivo Nacional milhões de páginas de documentos, entre os quais muitos pertencentes aos arquivos do extinto Serviço Nacional de Informações (SNI).

No mesmo sentido, arquivos estaduais têm reunido acervos dos órgãos de polícia política e de outras repartições públicas ligadas a eles, como os institutos médicos legais e os órgãos de criminalística. As atividades da Comissão seriam, também segundo o relatório, orientadas pela consulta permanente aos acervos públicos. A Comissão, aliás, montaria escritórios propriamente destinados à pesquisa junto ao Arquivo Nacional, no Rio de Janeiro e em Brasília, e no Arquivo Público do Estado do Rio de Janeiro (APERJ).

Já a Lei 12.528/2011, que estabeleceu afinal os parâmetros da CNV, previu como finalidade da Comissão examinar e esclarecer, no âmbito da Casa Civil da Presidência da República, as graves violações de direitos humanos praticadas no período de 1946 a 1988, 
a fim de promover a "reconciliação nacional" (artigo $1^{\circ}$ ). Presente também na lei que criou a Comissão de Mortos e Desaparecidos Políticos em 1995, bem como em votos do julgamento da ADPF 153, e tendo sua origem na própria Lei de Anistia, o objetivo da “(re)conciliação nacional” reaparecia assim como central no desenvolvimento da justiça de transição no Brasil. Levando em conta este objetivo, e se referindo à necessidade de observância da Lei de Anistia, o dispositivo legal também assegurava que os trabalhos de seus membros não teriam caráter jurisdicional ou persecutório (parágrafo $4^{\circ}$ do artigo $4^{\circ}$ ).

Como vimos nos capítulos anteriores, a (re)conciliação nacional tal como elaborada a propósito da legislação e da jurisprudência atinentes à justiça de transição no Brasil possui, em seus contornos tradicionais, um sentido eminentemente relacional entre agressores e vítimas, entre partidários do regime militar e opositores. Ela abrange, desta forma, um objetivo de apaziguamento e de conquista de uma estabilidade política e social sem a qual o país não pode avançar. Esta (re)conciliação, como foi explorado em passagens dos capítulos 2 e 3, ainda em seu sentido tradicional, seria associada a um dos principais pilares a promover a redemocratização, de modo que, em alguma medida, atualizá-la via CNV assumiria uma dimensão de atualização da própria origem do novo regime democrático.

Entretanto, em pelo menos um aspecto, o sentido de (re)conciliação nacional veiculado pela Lei $12.528 / 2011$ já não poderia remeter aos predicados tradicionalmente associados àquela categoria. Refiro-me à questão do esquecimento das violações e do silêncio de histórias e narrativas negadas por décadas a fio desde a repressão política. Como vimos no capítulo 2, já desde os trabalhos das comissões de reparação, especialmente a partir de 2007, a bandeira pela verdade, pela preservação da memória das violações e da estrutura autoritária, se não contestaria a essência do sentido tradicional associado à (re)conciliação, pelo menos substituiria um de seus predicados mais importantes, o esquecimento, pela memória. Veremos mais adiante se a CNV seria capaz, ao longo de seus trabalhos, de avançar a substituição ou contestação de mais algum daqueles predicados de modo a fazer água no trabalho das comissões de reparação nos últimos anos no sentido de tensionar os contornos tradicionais da (re)conciliação nacional.

A Lei 12.528/2011 também conferiu à CNV o poder de convocação de pessoas que pudessem ter alguma relação com os fatos e circunstâncias por ela examinados. Isto significa que, em caso de recalcitrância ou resistência, a pessoa poderia ser conduzida 
coercitivamente pela Polícia Federal para comparecer à audiência. ${ }^{10}$ A Lei também conferiu à $\mathrm{CNV}$ o poder de requisitar (que é uma espécie de requerimento, mas com caráter obrigatório) documentos e informações de outros órgãos da Administração Pública, mesmo os classificados em qualquer grau de sigilo. Nestes casos, de acordo com o parágrafo $2^{\circ}$ do artigo $4^{\circ}$, a CNV poderia utilizar as informações para a instrução de seu relatório final, mas não poderia disponibilizá-las a terceiros ou divulgá-las. Além disso, a lei também previa a colaboração de outros órgãos públicos nas atividades da $\mathrm{CNV}$.

Tendo em vista o que consideravam como limites do projeto de lei, a Comissão de Familiares de Mortos e Desaparecidos Políticos e o Coletivo de Mulheres pela Verdade e Justiça elaboraram um abaixo-assinado em que sugeriam algumas mudanças no projeto. Entre estas mudanças, a petição pleiteava: a delimitação do escopo de investigação da Comissão sobre o período do regime militar, a ampliação no número de membros, a substituição da expressão "reconciliação nacional" pela expressão "consolidação da democracia", orçamento próprio e autonomia administrativa, entre outras sugestões.

Já o senador Aloysio Nunes Ferreira (PSDB-SP), em seu parecer sobre o projeto de lei à Comissão de Constituição e Justiça do Senado, não só consubstanciava a anuência do principal partido de oposição ao projeto do governo para uma comissão da verdade, como reagia a algumas das principais críticas dirigidas ao projeto. ${ }^{11}$ Para o senador, além de mostrar a autoria de torturas, assassinatos, desaparecimentos forçados e ocultação de cadáveres, a Comissão teria uma tarefa mais ampla: identificar e tornar público o funcionamento da estrutura repressiva montada no tempo da ditadura (Cf. Nunes Ferreira, 2011). Ainda de acordo com este parecer, o formato legal da Comissão não determinaria de antemão tudo o que poderia vir a ser o órgão. Sobre as críticas atinentes à curta duração de dois anos dos trabalhos tendo em vista seu escopo dilatado, o parecer também destacou que a Comissão não iniciaria seus trabalhos da estaca zero, mas poderia e deveria (conforme a lei) valer-se de documentos e relatórios já produzidos pela Comissão de Anistia e pela Comissão Especial de Mortos e Desaparecidos Políticos, entre outros órgãos federais e estaduais.

Como destaca o último relatório de acompanhamento do ISER sobre a $\mathrm{CNV}$, vários aspectos do projeto de lei e da instalação da Comissão foram criticados por

\footnotetext{
${ }^{10}$ Embora o parágrafo $3^{\circ}$ do artigo $4^{\circ}$ da Lei $12.528 / 2011$ estabelecesse que servidores públicos e militares teriam o dever legal de colaborar com a Comissão, em muitos casos, a Justiça Federal asseguraria o direito constitucional dos depoentes de permanecerem em silêncio nas audiências. Mas o poder de convocação da CNV não seria comprometido.

${ }_{11} \mathrm{O}$ parecer do senador pode ser obtido pelo seguinte endereço eletrônico: http://legis.senado.leg.br/mateweb/arquivos/mate-pdf/98119.pdf. Último acesso em 04 de maio de 2015.
} 
entidades da sociedade civil (Cf. ISER, 2015, p. 23-24). Entre as principais críticas estavam a falta de audiências no Congresso ou no Planalto em que as entidades pudessem discutir o projeto com o poder público e a impossibilidade de estas entidades indicarem nomes para a composição da Comissão da Verdade. O Comitê Paulista Memória, Verdade e Justiça, por exemplo, divulgou nota, em maio de 2012, manifestando-se contrário à nomeação de Gilson Dipp como membro da Comissão por ter sido ele representante do Estado brasileiro no caso Guerrilha do Araguaia junto à Corte Interamericana, posicionando-se, portanto, contra a demanda dos familiares de desaparecidos naquele caso. $^{12}$

A cerimônia de instalação da $\mathrm{CNV}$, realizada no Palácio do Planalto em maio de 2012, contou com a participação de todos os ex-presidentes do regime democrático instaurado a partir da eleição do primeiro governo civil após o regime militar, exceto Itamar Franco. De certa forma, a composição dos sete membros da CNV exprimia em alguma medida uma espécie de meio-termo das principais forças políticas representadas nos governos civis eleitos após o regime militar. Embora não contasse com políticos de carreira, a Comissão foi investida por um ex-ministro da Justiça do governo Fernando Henrique Cardoso, José Carlos Dias; um ministro do Superior Tribunal de Justiça também indicado por Fernando Henrique, Gilson Dipp; um ex-ministro da Justiça do governo José Sarney, José Paulo Cavalcanti Filho; uma psicanalista associada com algumas demandas da esquerda, Maria Rita Kehl; um ex-secretário de Direitos Humanos do governo Fernando Henrique Cardoso, Paulo Sérgio Pinheiro; uma antiga advogada de presos políticos, Rosa Maria Cardoso da Cunha; e um ex-procurador-geral da República do governo Lula, Claudio Fonteles. Gilson Dipp e Claudio Fonteles renunciariam a seus cargos, respectivamente, em abril e setembro de 2013. Um dia depois da renúncia de Claudio Fonteles ${ }^{13}$, a presidência nomearia Pedro de Abreu Dallari, professor de Direito da USP, para compor o conselho, que terminou, portanto, com seis membros. Além dos membros, estiveram formalmente ligados à Comissão, em fases e períodos distintos, 217

\footnotetext{
${ }^{12}$ A nota do Comitê pode ser lida em: "Comitê Paulista Memória Verdade e Justiça quer Gilson Dipp fora da Comissão da Verdade". Vi O Mundo. São Paulo, 15 maio 2012. Denúncias. Disponível em: http://www.viomundo.com.br/denuncias/comite-gilson-dipp-fora-da-comissao-da-verdade-poiscompromete-a-sua-isencao.html. Último cesso em: 4 maio 2015.

${ }^{13} \mathrm{O}$ comissionado alegou questões pessoais, mas várias fontes informaram a mídia que a razão principal de sua saída teriam sido desentendimentos com os demais membros da Comissão a respeito de seu funcionamento. Cf., por exemplo, matéria IGLESIAS, S.; EBOLI, e.; BRÍGIDO, C. "Cláudio Fonteles deixa Comissão da Verdade por divergência internas". O Globo. Rio de Janeiro, 18 jun. 2013. Cadernos Brasil. Disponível em: http://oglobo.globo.com/brasil/claudio-fonteles-deixa-comissao-da-verdade-pordivergencias-internas-8727936. Acesso em: 4 maio 2015.
} 
colaboradores, entre assessores, funcionários públicos cedidos por outros órgãos, pesquisadores, consultores, auxiliares técnicos e administrativos, estagiários e voluntários, que trabalharam na sede, em Brasília, e em escritórios da Comissão no Rio de Janeiro e em São Paulo.

\subsection{3) As atividades da CNV e a interação com a sociedade civil}

O caput do artigo primeiro da Lei 12.528/2011 estabelecia que a Comissão da Verdade teria a finalidade de "examinar e esclarecer as graves violações de direitos humanos praticadas entre 1946 e 1988" (o período fixado pela extensão da anistia no ADCT, como vimos no capítulo 2). A fim de qualificar melhor o que entendia por "graves violações de direitos humanos" no âmbito de seus trabalhos, em agosto de 2012, a CNV editou sua resolução $\mathrm{n}^{\mathrm{o}}$ 2, a qual detalhou seu escopo nos seguintes termos: "examinar e esclarecer as graves violações de direitos humanos praticadas no período fixado no artigo $8^{\circ}$ do Ato das Disposições Constitucionais Transitórias, por agentes públicos, pessoas a seu serviço, com apoio ou no interesse do Estado" (CNV, 2012a - destaques acrescidos). ${ }^{14}$

A CNV excluía assim de suas investigações a atuação dos grupos armados que se opuseram à ditadura. Segundo o próprio relatório final publicado pela Comissão (CNV, 2014h), este recorte seria mais condizente com o desenvolvimento do direito internacional dos direitos humanos, que daria o marco legal fundamental, também de acordo com o relatório final, para os trabalhos da Comissão. Passariam a ser consideradas como graves violações as prisões ilegais, tortura, homicídio, violências sexuais, ocultações de cadáveres e desaparecimentos forçados. Quando tidos como de prática sistemática, estes crimes passariam a ser considerados como de lesa-humanidade pela Comissão. Este procedimento, conforme o relatório final (CNV, 2014h), teria por base a jurisprudência de tribunais internacionais.

No mês seguinte, pela resolução de $n^{0}$, a CNV (2012b) determinou que, com a criação de diversas comissões da verdade pelo país que poderiam colaborar com seu trabalho, evitaria a superposição desnecessária de investigações sobre fatos e

\footnotetext{
14 Esta resolução pode ser obtida no seguinte endereço eletrônico: http://www.cnv.gov.br/images/pdf/resolucao_02_200812.pdf. Último acesso em 12 de maio de 2015.
} 
circunstâncias dos casos de graves violações. ${ }^{15} \mathrm{E}$ a partir de dezembro de 2012, boa parte das atividades de pesquisa passou a ser realizada por grupos de trabalho coordenados por diferentes membros. A Comissão criou 13 grupos de trabalho, divididos por temas: 1) ditadura e gênero; 2) Araguaia; 3) contextualização, fundamentos e razões do golpe civilmilitar de 1964; 4) ditadura e sistema de Justiça; 5) ditadura e repressão aos trabalhadores e ao movimento sindical; 6) estrutura da repressão; 7) mortos e desaparecidos políticos; 8) graves violações de direitos humanos no campo ou contra indígenas; 9) Operação Condor; 10) papel das igrejas durante a ditadura; 11) perseguições a militares; 12) violações a direitos humanos de brasileiros no exterior e de estrangeiros no Brasil; e 13) o Estado ditatorial-militar (Cf. CNV, 2014h, p. 51).

Durante seus cerca de dois anos e meio de funcionamento, a CNV colheu 1.121 depoimentos, sendo 132 de agentes públicos, e realizou 80 audiências e sessões públicas em 20 unidades da federação. A partir de maio de 2013, as audiências públicas passaram a ser veiculadas em tempo real pela internet, nas páginas da Comissão pelo Youtube, Facebook, Twitter e pelo próprio site, o qual, segundo o relatório, foi acessado mais de um milhão e trezentas mil vezes até outubro de 2014 . No período, também foram realizadas várias diligências investigativas, entre elas dezenas de perícias. Os restos mortais de um desaparecido foram identificados no período: de Epaminondas Gomes de Oliveira, camponês militante do PCB. Com peritos e vítimas da repressão, a CNV visitou 7 unidades militares e locais usados pelas Forças Armadas no passado em que foram cometidas torturas e outras violações.

As novas diligências de investigação levadas adiante pela CNV também tinham o condão de buscar "verdades" ainda desconhecidas ou ainda pouco ou pobremente documentadas até então. Afinal, como foi discutido no capítulo 2, apesar de pelo menos a Comissão de Anistia realizar diligências de próprio punho uma vez tendo início o processo sobre o pedido de anistia (algo que não ocorria na CEMDP, que considerava as provas fundamentalmente trazidas pelos interessados), assim como a CEMDP, a Comissão de Anistia age fundamentalmente quando incitada a fazê-lo a propósito destes processos. Caravanas e inspeções de centros clandestinos por parte da Comissão de Anistia também foram importantes, mas sua função central tem sido, além de processar os pedidos de anistia, divulgar e problematizar a memória sobre o período. Já a Comissão da Verdade teria a finalidade de revelar ex officio (isto é, por iniciativa própria) o máximo de 
“verdade” possível sobre as violações cometidas pela repressão política.

De todo modo, o trabalho junto a pesquisas e documentos já existentes foi o que tomou a maior parte do empreendimento investigativo da Comissão, uma vez que seus membros identificaram na sistematização das informações já disponíveis uma das maiores, se não a maior, contribuição que a $\mathrm{CNV}$ poderia fazer em termos de reconhecimento do Estado e de divulgação e problematização pública do passado de atrocidades. Equipes de assessores e pesquisadores da CNV se debruçaram sobre o arquivo sobre a ditadura na Unicamp, sobre os documentos do Arquivo Nacional (trazidos de vários órgãos públicos e de forças de segurança por força de lei), sobre o livro Direito à memória e à verdade e processos administrativos da CEMDP e sobre processos administrativos da Comissão de Anistia. A ideia era, segundo o próprio relatório final, sistematizar as informações já constantes, especialmente no livro Brasil: nunca mais e nas publicações da CEMDP e da Comissão de Anistia. ${ }^{16}$

Especialmente com a CEMDP, a CNV estabeleceu uma parceria mais intensa, em parte porque focou seus trabalhos sobretudo nas mortes e desaparecimentos, aos quais dedicaria um dos três volumes de seu relatório final. Mas a atuação da CNV com relação aos mortos e desaparecidos políticos iria além da sistematização das circunstâncias que cercaram as mortes e desaparecimentos e envolveria também trabalhos conjuntos com a CEMDP na tentativa de identificação de restos mortais e de retificação de registros de óbitos de vítimas da ditadura. Em agosto de 2012, ao lado da CEMDP, a CNV recomendou à $2^{\text {a }}$ Vara de Registros Públicos de São Paulo, a retificação do registro de óbito do jornalista Vladimir Herzog, conforme havia sido solicitado por sua família àquele juízo. No mês seguinte, a Vara concedeu o pedido para fazer constar que a morte do jornalista decorrera de lesões e maus-tratos sofridos nas instalações do DOI-CODI do

\footnotetext{
${ }^{16}$ Os principais arquivos pesquisados guardavam principalmente documentos do Serviço Nacional de Informações (SNI), do Centro de Informações de Segurança da Aeronáutica (CISA), do Centro de Informações do Exterior (Ciex), da Divisão de Inteligência da Polícia Federal, dentre outros. O acervo da CNV será transferido ao Arquivo Nacional, como prevê a lei. Segundo o relatório final da Comissão, também foram consultados: os Arquivos Públicos dos Estados de São Paulo, Rio de Janeiro, Minas Gerais, Paraná, o Arquivo Histórico do Rio Grande do Sul e o Arquivo Público Estadual Jordão Emerenciano, em Pernambuco. A CNV também mapeou os acervos das polícias políticas dos estados de Minas Gerais, Goiás e Rio de Janeiro, bem como do Distrito Federal. Junto ao Instituto Histórico e Geográfico Brasileiro (IHGB), a Comissão teve acesso ao Acervo Médici. O Ministério do Trabalho e Emprego também disponibilizou aos pesquisadores da CNV o acesso a seus arquivos, que contêm informações sobre casos de demissão de sindicalistas, intervenção em sindicatos, repressão a greves, bem como sobre a atuação da Divisão de Segurança e Informações do próprio Ministério, e das assessorias de segurança e informação. Por fim, a Comissão também se debruçou sobre os acervos do Superior Tribunal Militar (STM), em Brasília, e do Instituto de Criminalística Carlos Éboli, no Rio de Janeiro, além dos acervos pessoais de ex-perseguidos políticos e familiares (Cf. CNV, 2014h, p. 60 e 61). Como foi mencionado acima, os processos da Comissão de Anistia e da CEMDP também foram fonte central para a CNV.
} 
Segundo Exército, e não por asfixia mecânica auto-infligida, como determinavam o laudo necroscópico e o registro de óbito. Em outubro de 2013, a CNV reforçou também o pedido de mudança no registro de óbito do então estudante Alexandre Vannuchi Leme originalmente veiculado por seus irmãos (incluindo o ex-secretário de Direitos Humanos da Presidência da República no governo Lula e atual membro da Comissão Interamericana de Direitos Humanos, Paulo Vannuchi). A mesma Vara de Registros Públicos em São Paulo determinaria meses depois também esta retificação.

Ainda em colaboração com a CEMDP, a CNV promoveu a exumação dos restos mortais do ex-presidente João Goulart, em São Borja (RS), em novembro de 2013, bem como outras investigações sobre mortes e desaparecimentos de outros militantes políticos em outros Estados. A CNV também apoiou formalmente as atividades da CEMDP para a reabertura dos trabalhos de antropologia forense com vistas ao exame das ossadas localizadas em 1989 na vala clandestina do Cemitério Dom Bosco, em Perus, na cidade de São Paulo.

Com relação à coleta de testemunhos e depoimentos de agentes da repressão, o relatório final diz que os 1.116 depoimentos colhidos foram essenciais para $\mathrm{o}$ “esclarecimento circunstanciado" (CNV, 2014h, p. 55) de vários casos de graves violações aos direitos humanos e para a reconstrução histórica das estruturas de repressão. Ainda segundo o relatório, do total de depoimentos, 483 foram tomados em audiências públicas, e 633, em sigilo. Outras comissões da verdade e grupos engajados na temática há décadas indicaram os nomes mais importantes a serem entrevistados a princípio pela CNV. Militantes que participaram da luta armada e sofreram tipos variados de perseguição política foram classificados pela Comissão como "vítimas" e, como vimos, suas ações não foram objeto de exame pela Comissão. As denominadas vítimas ou se dispuseram voluntariamente a dar testemunho de seus suplícios ou foram convidadas pela Comissão a fazê-lo. Já os agentes da repressão foram efetivamente convocados, mediante notificação encaminhada pela Polícia Federal.

$\mathrm{Na}$ medida em que a tomada de testemunhos e depoimentos começou relativamente tarde em relação ao tempo de funcionamento da Comissão (fundamentalmente a partir de seu segundo ano), para alcançar o número expressivo de entrevistas que alcançou, a Comissão disponibilizou por meio de seu site na internet "Formulários padrão para depoimentos e testemunho". O relatório final também informou que manteve sigilo sobre o nome dos depoentes quando estes o requereram.

Tendo em vista o objetivo de promover a memória histórica e recomendar a 
adoção de políticas públicas de não repetição, a CVN realizou o reconhecimento de locais em que foram cometidas graves violações entre 1946 e 1988 e apoiou iniciativas para a transformação de prédios onde ocorreram torturas e execuções em lugares de memória (Cf. CNV, 2014h, p. 56). Nas visitas realizadas em 11 instalações públicas civis e militares, presos políticos reconheceram os locais em que ocorreram as prisões ilegais, torturas, desaparecimentos, execuções e ocultações de cadáveres. A CNV recomendou, em outubro de 2012, ao governo do Estado de São Paulo e ao Ministério do Planejamento, a transformação do prédio onde funcionou o DOI-CODI (atual sede do $36^{\circ}$ Distrito Policial do Estado) e do imóvel onde se instalava a Auditoria da Justiça Militar em centros de memória. Em agosto de 2013, este último imóvel foi colocado à disposição da seção de São Paulo da OAB para a construção do Memorial da Luta pela Justiça - Advogados Brasileiros contra a Ditadura, que será destinado a resgatar a atuação dos advogados na defesa de presos políticos no período militar. Já o antigo prédio do DOI-CODI em São Paulo seria tombado em janeiro de 2014 como lugar de memória. Ainda no final de 2012, a CNV também solicitou ao então governador do Estado do Rio Grande do Sul, Tarso Genro, o tombamento da antiga sede do Departamento de Ordem Política e Social (DOPS) situado em Porto Alegre e que foi extinto em 1982.

A Comissão visitou e fez recomendações acerca de outros lugares do gênero. Ao então governador do Rio de Janeiro, Sérgio Cabral, e ao prefeito da cidade, Eduardo Paes, a CNV recomendou a transformação dos antigos prédios do DOPS e do DOI-CODI do Primeiro Exército em espaços públicos de memória. No antigo prédio do DOPS funciona hoje um museu da polícia do Estado. Esta atividade da CNV mereceu destaque aqui porque diz respeito a um legado que pode ser duradouro acerca da preservação da memória sobre a repressão do regime militar. Além disso, a transformação de antigos prédios onde ocorreram atividades como prisões ilegais, torturas, homicídios e desaparecimentos, em lugares de memória espalhados por todo o país pode ajudar a dar mais capilaridade ao tema, o que é especialmente importante em um país de dimensões continentais como o Brasil.

Além de seus trabalhos com as comissões de reparação, a CNV realizou atividades com uma série de outros órgãos públicos. Conforme sustenta seu relatório final (CNV, 2014h, p. 69), sua instalação criou um cenário favorável para o surgimento de várias comissões da verdade estaduais, municipais, universitárias, sindicais e de outras entidades. O relatório final não possui um levantamento exato sobre o número de comissões da verdade, mas atesta terem se formado mais de uma centena. Com algumas delas, a CNV 
celebrou 43 contratos de cooperação técnica, destinados, sobretudo, à troca de informações e documentos e, secundariamente, à organização de atividades conjuntas, tais como audiências públicas e diligências investigativas. Os documentos encaminhados por outras comissões da verdade à CNV também serão destinados ao acervo da Comissão a ser instalado no Arquivo Nacional.

Organizações internacionais também realizaram atividades conjuntas com a CNV. Em outubro de 2013, a Comissão celebrou contrato de cooperação técnica com o Programa das Nações Unidas para o Desenvolvimento (PNUD).O objetivo do projeto intitulado "Fortalecimento da Comissão Nacional da Verdade" era concentrar o processo de contratação de pesquisadores, assistentes e peritos, que prestaram assessoria técnica voltada à realização de algumas das principais atividades da CNV. Também o International Center for Transitional Justice (ICTJ), organização não governamental reconhecida como referência internacional no campo da justiça de transição, ofereceu treinamento técnico à equipe da Comissão, bem como teceu recomendações e análises sobre os trabalhos da CNV.

Mas certamente o relacionamento institucional mais tenso dar-se-ia com as Forças Armadas, objeto central das investigações sobre graves violações aos direitos humanos na ditadura, e com o Ministério da Defesa, que procura engendrar, desde 1999, o controle civil sobre as Forças Armadas. Durante os dois anos e meio de suas atividades, a CNV tentou obter informações e documentos relacionados à repressão política e que estivessem sob a responsabilidade ou guarda das Forças Armadas. De acordo com o relatório final (CNV, 2014h, p. 64), 84 ofícios foram enviados ao Ministério da Defesa e seus respectivos comandos, dos quais 53 tratavam de solicitações de informações, 22 de solicitações de visitas técnicas, quatro de encaminhamentos, um de convocação, três de pedidos de apoio logístico e um de confirmação de recebimento. De acordo com a CNV, poucos dos ofícios relacionados a pedidos de informações foram satisfatoriamente atendidos.

Em 2014, as Forças Armadas realizaram, a pedido da CNV, algumas sindicâncias para investigação de "desvio de conduta" no desempenho de suas funções em razão da prática de graves violações aos direitos humanos durante o período militar. A CNV solicitou na ocasião esclarecimentos sobre a forma e os motivos que levaram a que sete instalações militares localizadas nos Estados do Rio de Janeiro, São Paulo, Minas Gerais e Pernambuco fossem utilizadas contínua e sistematicamente para a prática de tortura e execuções durante o regime militar. 
Os comandantes das três Forças instauraram, no final de março de 2014, as sindicâncias solicitadas. $\mathrm{O}$ Ministério da Defesa encaminhou à $\mathrm{CNV}$, em junho do mesmo ano, ofício com os relatórios das três sindicâncias, nos quais, de forma bastante homogênea (Cf. CNV, 2014h, p. 65-66), constatou-se não ter havido desvio de finalidade no uso daquelas instalações. Em resposta ao resultado das sindicâncias, em agosto de 2014 a CNV encaminhou novo ofício ao Ministério da Defesa perguntando se o Ministério e os comandos do Exército, Marinha e Aeronáutica reconheciam a validade dos atos oficiais do Estado brasileiro que haviam constatado a prática das graves violações naquelas dependências. Em resposta, tanto o Ministério quanto os comandantes ressaltaram que não negavam a validade dos atos oficiais. A CNV considerou como positivas estas últimas respostas, mas ainda insuficiente a posição de não ter havido "de forma clara e inequívoca o expresso reconhecimento do envolvimento das Forças Armadas nos casos de tortura, morte e desaparecimento relatados pela CNV e reconhecidos pelo Estado" (CNV, 2014h, p. 66).

O relacionamento entre a CNV e as Forças Armadas contou ainda com a realização de reuniões periódicas que tinham por finalidade a viabilização do trânsito de informações entre os órgãos. No primeiro ciclo de reuniões, o objetivo era obter informações sobre mortos e desaparecidos políticos. A CNV submeteu a exame 456 casos, mas em apenas seis deles disse ter obtido informações relevantes das Forças Armadas. O segundo ciclo de reuniões tinha por escopo a obtenção de documentos sobre o assentamento funcional de militares. Houve também muita resistência por parte das Forças Armadas neste sentido, além de ações judiciais promovidas pessoalmente por alguns militares para que a Comissão não obtivesse as informações a seu respeito. No total, a CNV diz ter recebido 150 folhas de alterações funcionais de militares.

A Comissão também realizou algumas reuniões com ex-perseguidos políticos e familiares de mortos e desaparecidos. Em julho de 2013, entidades e movimentos envolvidos com a luta pela bandeira da chamada "memória, verdade e justiça" publicaram uma carta aberta em que criticavam a atuação da $\mathrm{CNV} .{ }^{17} \mathrm{~A}$ carta também demandava, entre outras medidas, a apresentação de um plano de trabalho em que se detalhassem os principais objetivos e a metodologia que seria utilizada pela Comissão em suas atividades, bem como a convocação de agentes da repressão (que até então não haviam sido

\footnotetext{
${ }^{17}$ Entre os grupos que assinaram a carta estão a Comissão de Familiares de Mortos e Desaparecidos Políticos, vários comitês estaduais Memória, Verdade e Justiça, entre outras entidades. A carta pode ser lida no seguinte endereço eletrônico: http://www.brasil247.com/pt/247/brasil/108681/Familiares-criticamComiss\%C3\%A3o-da-Verdade.htm. Último acesso em 04 de maio de 2015.
} 
convocados), a realização de mais audiências públicas, o foco da Comissão nos casos de mortes e desaparecimentos e uma maior pressão política para a total abertura dos arquivos dos órgãos ligados à repressão.

Procurando dar credibilidade a seu objetivo de redimir parte da história (especialmente relativa aos suplícios sofridos) dos perseguidos políticos, a CNV efetivamente se esforçou em atender às críticas e sugestões elaboradas pelos familiares de mortos e desaparecidos políticos, bem como incorporou em seu relatório relatos sobre a crítica construtiva dos grupos de familiares sobre seus trabalhos. Por exemplo, a partir de seu segundo ano de funcionamento, a CNV passou a realizar mais audiências públicas e a tomar depoimentos e testemunhos de ex-perseguidos políticos, familiares e agentes da repressão. Também deu centralidade aos mortos e desaparecidos políticos em suas atividades e no relatório final, que contou com um de seus três volumes dedicado à vida e às circunstâncias de perseguição sobre aquelas pessoas. $\mathrm{O}$ relatório final também deu destaque ao engajamento dos comitês de memória, verdade e justiça.

Entretanto, a falta da explicitação de uma metodologia clara sobre seus trabalhos, a tomada de muitos depoimentos de forma reservada e a demora na realização de um número maior de audiências públicas, bem como a escassa participação da sociedade civil no processo estiveram entre as principais críticas dirigidas às atividades da $\mathrm{CNV}$ em seu período de funcionamento. O ISER atribui a falta de metodologia e a demora na realização de audiências públicas à inexistência de um período de preparação da $\mathrm{CNV}$ antes do começo da contagem do prazo de seu funcionamento (Cf. ISER, 2015, p. 105 e seguintes). De certa forma, a pressa em instalar a Comissão e seu prazo exíguo de funcionamento não combinavam com o fato de, até então, o país ter passado 35 anos desde sua transição sem uma comissão do tipo. A pressa em produzir resultados também não combinava com a magnitude das investigações sobre 40 anos de violações aos direitos humanos (lembrando que seu escopo cobria também o conturbado período democrático anterior ao golpe militar). O ISER criticou ainda a escassa publicidade das atividades da CNV. Especialmente a agenda da Comissão era atualizada apenas depois ou, quando muito, nas vésperas da realização das atividades. Deste modo, grupos da sociedade civil tinham dificuldades em se organizarem para participar destas atividades, especialmente quando não eram realizadas nas cidades em que estão instalados.

De minha parte, também experimentei esta dificuldade. Tive a possibilidade de acompanhar alguns eventos realizados pela $\mathrm{CNV}$ em conjunto com as comissões da verdade estadual e da Câmara Municipal de São Paulo. Além disso, quando fui a Brasília 
entrevistar o presidente da Comissão de Anistia, Paulo Abrão, tive a oportunidade, por uma coincidência de agendas, de estar presente na audiência em que o coronel reformado Carlos Alberto Brilhante Ustra, o cabo Anselmo e o vereador (e presidente da Comissão da Verdade da Câmara Municipal de São Paulo) Gilberto Natalini foram entrevistados por comissionados da CNV. O vereador do Partido Verde, que também viria a me conceder uma entrevista meses mais tarde, fora torturado por Ustra. De todo modo, se mesmo para o ISER, instituição que contava com vários pesquisadores e com um grupo com recursos destinados quase que exclusivamente ao acompanhamento das atividades da CNV enquanto ela funcionou foi difícil realizar uma pesquisa de campo, de minha parte, sem a possibilidade de fazer um planejamento com antecedência e com recursos mais limitados (além de ter na CNV apenas um dos focos de minha pesquisa), a tarefa de acompanhamento teve de se limitar a algumas audiências realizadas em São Paulo, a uma entrevista que a comissionada Rosa Cardoso aceitou em conceder-me e, no mais, utilizeime do site da Comissão e de sua página no Youtube para assistir às demais audiências gravadas e ler os relatórios parciais e final.

O ISER também realizou algumas pesquisas qualitativas com comitês de memória, verdade e justiça, bem como com organizações engajadas na luta mais abrangente pela afirmação dos direitos humanos, para aferir uma avaliação mais detalhada destas organizações sobre as atividades da CNV. Com relação às audiências promovidas pela Comissão, por exemplo, em geral as entidades que responderam aos questionários do ISER ressaltaram a baixa participação da sociedade civil nestas atividades, tanto com relação à sua presença nas audiências, quanto em relação às possibilidades de manifestação que tiveram, quando puderam estar presentes. Com relação ao sigilo de muitos depoimentos, o que também foi bastante criticado, a CNV ressaltou: "a manutenção do sigilo sobre alguns depoimentos é fundamental para que a Comissão da Verdade possa dar os passos seguintes, uma vez que um depoimento sempre traz indicativos de outros que podem ser colhidos. Divulgar determinadas linhas de investigação nesse momento prejudicaria sensivelmente a colheita de dados pela CNV", ${ }^{18}$

No que diz respeito ao relacionamento com familiares de mortos e desaparecidos políticos, embora o relatório final destaque que os encontros tenham sido frequentes, a falta de espaços participativos e de reciprocidade da Comissão foram constantes críticas

\footnotetext{
${ }^{18}$ Ver Assessoria de Comunicação da Comissão Nacional da Verdade. "Comissão da Verdade define estratégias de funcionamento e de estruturas". Brasília, 2 jul. 2012. Destaques. Disponível em: http://www.cnv.gov.br/index.php/outros-destaques/72-comissao-da-verdade-define-estrategias-defuncionamento-e-estrutura. Último acesso em 04 de maio de 2015.
} 
direcionadas a ela (Cf. ISER, 2015, p. 132). Na reunião que fez com os familiares em junho de 2013, o comissionado José Carlos Dias reconheceu algumas destas críticas, especialmente a necessidade de maior transparência da Comissão e participação efetiva de familiares. ${ }^{19}$ Naquela ocasião, os familiares apresentaram documento que unificava, entre suas principais demandas, mais uma vez, o foco das investigações no período pós-golpe de 1964, a prioridade para a investigação de casos de mortes e desaparecimentos, a abertura dos arquivos das forças armadas, a oitiva dos sobreviventes sobre as torturas e a convocação de agentes da repressão para prestarem depoimentos. Mas ainda foram destacadas a necessidade de investigação sobre as violações cometidas contra camponeses, trabalhadores rurais, povos indígenas, garimpeiros e comunidades tradicionais; e sobre as relações entre Estado e sociedade no curso do regime autoritário. Os familiares também ressaltaram a importância de se investigar a operação Condor e a relação da ditadura brasileira com outros regimes militares do Cone Sul, bem como a necessidade de se apurar o envolvimento do Poder Judiciário com a repressão. Além disso, os familiares requereram também a prestação de assistência psicológica e médica às vítimas que se dispusessem a depor. Maior frequência e permeabilidade das audiências públicas e da transparência nas atividades da $\mathrm{CNV}$ foram igualmente objeto das demandas dos familiares. $^{20}$

O segundo encontro com familiares foi realizado em abril de 2013. Nele foram organizados debates por grupos temáticos a partir dos quais foi redigido um documento também dirigido à CNV (cf. ISER, 2015, p. 141 e seguintes). Todos os grupos temáticos discutiram e elaboraram críticas e demandas à Comissão, mais uma vez, no que diz respeito à metodologia de trabalho, à falta de realização de audiências públicas em alguns estados, entre outros. ${ }^{21}$ Apenas mais dois encontros foram realizados com a sociedade civil no formato de audiência pública, ainda que parcial: um em junho de 2013, com familiares de perseguidos políticos, e outro em dezembro do mesmo ano, com entidades engajadas no campo memória, verdade e justiça.

\footnotetext{
${ }^{19}$ Cf. DUARTE, N. "Ex-ministro reconhece falhas em Comissão Nacional da Verdade”. G1. São Paulo, 26 jun. 2013. Disponível em: http://g1.globo.com/sao-paulo/noticia/2013/06/ex-ministro-reconhece-falhas-emcomissao-nacional-da-verdade.html. Acesso em: 4 maio 2015.

${ }^{20} \mathrm{O}$ documento de compilação das sugestões e demandas apresentadas à CNV em seu primeiro encontro com os familiares pode ser obtido no seguinte endereço eletrônico: http://coletivorj.blogspot.com.br/2012/08/comites-protocolam-demandascomissao.html. Último acesso em 04 de maio de 2015.

${ }^{21} \mathrm{Na}$ coletiva de imprensa que se seguiu, a maior parte dos jornalistas focou suas perguntas na declaração do comissionado Paulo Sérgio Pinheiro de que o relatório final da CNV abrangeria a identificação da autoria das graves violações aos direitos humanos que serviriam à reinterpretação da Lei de Anistia.
} 
Ao longo de seus trabalhos, a CNV também apresentou publicamente relatórios parciais de pesquisa. O primeiro relatório preliminar foi divulgado em fevereiro de $2014 \mathrm{e}$ teve por objeto principal a exposição do funcionamento de algumas instalações militares onde ocorreram torturas e outros crimes praticados por agentes públicos. ${ }^{22}$ Além disso, neste relatório, a CNV (2014a) também divulgou a emissão de ofício ao Ministério da Defesa a fim de que se instaurassem sindicâncias para a apuração de "desvio de finalidade" no desempenho das funções das Forças Armadas durante o regime militar. O segundo relatório parcial (CNV, 2014b), apresentado no Rio de Janeiro ainda no mesmo mês, ocupou-se prioritariamente do desaparecimento do então deputado federal Rubens Paiva, ilegalmente preso, torturado e executado em janeiro de $1971 .{ }^{23} \mathrm{Na}$ mesma cidade, no mês seguinte, o terceiro relatório parcial $(\mathrm{CNV}, 2014 \mathrm{c})$ cuidou de retratar a chamada Casa da Morte, centro de execução e tortura localizado em Petrópolis. ${ }^{24}$ Apresentado em São Paulo em abril do mesmo ano, o quarto relatório preliminar (CNV, 2014d) deu conta dos centros clandestinos similares à Casa da Morte que funcionaram em vários locais por todo o país durante a década de $1970 .{ }^{25} \mathrm{O}$ quinto relatório preliminar $(\mathrm{CNV}, 2014 \mathrm{e})$ divulgou os resultados da perícia da CNV sobre a morte do ex-presidente Juscelino Kubitschek. ${ }^{26}$ Seu resultado, em que se atestava a morte acidental do presidente, foi objeto de polêmica com outros grupos ativistas de direitos humanos e especialmente com a Comissão da Verdade da Câmara Municipal de São Paulo, cujas investigações a respeito do caso chegaram à conclusão a respeito de homicídio do ex-presidente e de seu motorista (Cf. Comissão Municipal da Verdade Vladimir Herzog, 2012). ${ }^{27}$

\footnotetext{
$22 \mathrm{O}$ primeiro relatório preliminar da $\mathrm{CNV}$ pode ser obtido no seguinte link: http://www.cnv.gov.br/images/pdf/relatorio_versao_final18-02.pdf. Último acesso em 04 de maio de 2015. ${ }^{23} \mathrm{O}$ segundo relatório preliminar pode ser obtido no seguinte endereço eletrônico: http://www.cnv.gov.br/images/pdf/relatorio_preliminar_26-02.pdf. Último acesso em 04 de maio de 2015. ${ }^{24} \mathrm{O}$ terceiro relatório preliminar está disponível no seguinte endereço eletrônico: http://www.cnv.gov.br/images/pdf/petropolis/Versao_final_-_Casa_da_Morte_relatorio_preliminar_revisado.pdf. Último acesso em 04 de maio de 2015.

${ }^{25} \mathrm{O}$ quarto relatório preliminar está disponível nos seguintes endereços eletrônicos: Parte I (http://www.cnv.gov.br/images/pdf/Relatorio_CNV_Centros_Clandestinos-p1.pdf), Parte II (http://www.cnv.gov.br/images/pdf/Relatorio_CNV_Centros-Clandestinos-parte2.pdf). Último acesso em 04 de maio de 2015.

${ }_{26} \mathrm{O}$ quinto relatório preliminar está disponível no seguinte endereço eletrônico: http://www.cnv.gov.br/images/pdf/jk/relatorio_preliminar_jk.pdf. Último acesso em 04 de maio de 2015.

${ }^{27}$ A Advocacia Geral da União, que havia defendido a constitucionalidade da bilateralidade da anistia na ADPF 153 (como vimos no capítulo anterior), representou judicialmente e extrajudicialmente a CNV (cujos membros, por sua vez, manifestamente se colocaram a favor do julgamento e condenação de agentes da repressão) em ações judiciais promovidas por indivíduos ou instituições contra a Comissão, inclusive no mandado de segurança impetrado pela Comissão da Verdade da Câmara Municipal de São Paulo tendo em vista a necessidade de a CNV considerar obrigatoriamente elementos da investigação realizada pela Comissão Municipal sobre o caso Kubitschek. A ação foi extinta sem julgamento de mérito pela Justiça Federal em Brasília.
} 
Já o sexto relatório parcial da CNV (2014f) traçou uma narrativa sobre o chamado caso Riocentro, atentado articulado por militares em comício comemorativo do Dia do Trabalhador, em $1981 .{ }^{28}$ Ainda em junho de 2014 foi apresentado o sétimo relatório preliminar (CNV, 2014g), como a maioria, também no Rio de Janeiro. ${ }^{29}$ Este relatório ocupou-se do caso Stuart Angel Jones, militante político desaparecido em 1971 e cujos restos mortais, assim como os de muitos outros desaparecidos, ainda não foram encontrados.

Depois do sétimo relatório preliminar, a CNV se concentrou na elaboração do relatório final. Mas ainda realizou uma audiência pública em agosto de 2014 para a coleta de depoimentos e apresentação de resultados de pesquisa sobre a Guerrilha do Araguaia. No mesmo mês, em Brasília, a CNV divulgou a descoberta dos únicos restos mortais encontrados durante sua atividade, identificados como sendo do antigo camponês militante Epaminondas Gomes de Oliveira.

\section{2) O relatório final da $\mathrm{CNV}$ e sua repercussão}

O relatório final foi entregue com três volumes totalizando mais de quatro mil páginas pela $\mathrm{CNV}$ à presidente Dilma Rousseff no dia 10 de dezembro (Dia Internacional dos Direitos Humanos) de 2014. A cerimônia foi realizada na sede do Conselho Federal da OAB em Brasília. Embora transmitida ao vivo pelo canal da CNV na internet, a audiência foi fechada à participação de representantes de alguns órgãos do poder público e de algumas entidades da sociedade civil previamente convidados. Depois o relatório também foi entregue aos presidentes do Senado Federal, da Câmara dos Deputados e do Supremo Tribunal Federal.

Além de configurar a descrição mais detalhada da estrutura da repressão e das circunstâncias de mortes e desaparecimentos políticos, indicando inclusive a autoria e a coordenação das práticas de violações aos direitos humanos por determinados agentes públicos, o relatório também reúne as recomendações da $\mathrm{CNV}$, em termos de políticas

\footnotetext{
$28 \mathrm{O}$ sexto relatório preliminar da CNV pode ser obtido no endereço eletrônico: http://www.cnv.gov.br/images/pdf/riocentro/relatorio_preliminar.pdf. Último acesso em 04 de maio de 2015.

${ }^{29} \mathrm{O}$ sétimo relatório preliminar da $\mathrm{CNV}$ pode ser obtido no endereço eletrônico: http://www.cnv.gov.br/images/pdf/STUART_ANGEL_rel_preliminar.pdf. Último acesso em 04 de maio de 2015.
} 
públicas e de mudança da jurisprudência, para um avanço contínuo da justiça de transição no país, a fim de que as violações sistemáticas do passado não mais se repitam. $\mathrm{O}$ secretário-geral da ONU, Ban Ki Moon, também esteve presente à ocasião e congratulou a Comissão por seus trabalhos, bem como o esforço do Estado brasileiro em promover a reconciliação e a busca pela memória, verdade e justiça. Também discursaram na cerimônia o presidente do Conselho Federal da $\mathrm{OAB}$, o presidente da $\mathrm{CNBB}$, entre outros representantes de algumas entidades da sociedade civil. Ismael Antônio de Souza, secretário das centrais sindicais, ao tomar a palavra destacou o papel das centrais em seu trabalho junto ao GT "Ditadura e repressão aos trabalhadores e ao movimento sindical", que foi coordenado pela comissionada Rosa Maria Cardoso.

Por outro lado, a Rede Brasil - Verdade, Memória e Justiça, que representa muitos dos grupos e comitês engajados no tema no país, divulgou uma nota crítica sobre a forma como foi realizada a cerimônia de entrega do relatório:

"a Rede Brasil - Verdade, Memória e Justiça, ao tomar conhecimento de que a entrega do Relatório Final da Comissão Nacional da Verdade não será em ato aberto à Nação, com a presença livre da sociedade civil e em conjunto com os três poderes da República e, ao contrário, será feita em audiência reservada com o Poder Executivo e em separado com o Congresso Nacional, vem a público, mais que lamentar, alertar para o fato de que passados 50 anos do golpe de 1964, as forças reacionárias que o viabilizaram e o sustentaram por 21 anos prosseguem subjugando a Nação, revelando que de fato não houve a necessária ruptura entre a ditadura e a democracia brasileira" (Rede Brasil - Verdade, Memória e Justiça apud ISER, 2015, p. 78).

\subsection{1) Estrutura do relatório final}

O relatório final desenhou a sistematização das informações sobre a prática de tortura no país a partir dos depoimentos de presos políticos interrogados por Tribunais Militares e que foram divulgados, em 1985, pela obra Brasil: nunca mais, publicada pela arquidiocese de São Paulo. Toda a documentação obtida pela arquidiocese na época foi transferida para os arquivos da Universidade Estadual de Campinas (Unicamp), que possibilita acesso ao público e foi uma das bases para os trabalhos da CNV.

Também o Dossiê de mortos e desaparecidos políticos a partir de 1964, obra organizada pela Comissão de Familiares de Mortos e Desaparecidos políticos a que nos referimos no capítulo 2, foi, segundo a $\mathrm{CNV}$, um dos fundamentos a partir dos quais se baseou a narrativa de seu relatório final. O dossiê ampliara a abrangência do projeto 
Brasil: nunca mais ao incluir em sua pesquisa informações sobre acervos de institutos médicos legais de São Paulo, Rio de Janeiro e Pernambuco e de diversas delegacias de ordem política e social, além de documentos privados de militares e ex-perseguidos políticos. Como também já foi comentado, as publicações da Comissão de Anistia e especialmente da CEMDP completaram o quadro das principais referências do relatório final da CNV.

É neste sentido que o primeiro volume do relatório final faz um histórico das políticas públicas de justiça transicional em nível federal no país. Especificamente com relação aos trabalhos da CEMDP, o relatório diz que a CNV teve a oportunidade de analisar os casos de mortes e desaparecimentos em compasso com tratados e decisões de órgãos internacionais posteriores à Lei 9.140/1995. Em segundo lugar, a CNV também destacou em seu relatório que não exigiu, para o reconhecimento da morte ou desaparecimento, a ligação da vítima a atividade política, o que possibilitou um pequeno aumento no cômputo das vítimas destes crimes (Cf. CNV, 2014h, p. 26-27). ${ }^{30}$ Desta forma, alguns camponeses, indígenas e religiosos que não puderam ser reconhecidos como merecedores de indenizações materiais em função dos critérios da Lei 9.140/1995 puderam ser reconhecidos como vítimas da repressão pela CNV. Outra diferença essencial em relação aos trabalhos da CEMDP foi a identificação da autoria das graves violações de direitos humanos. Sobretudo no volume 3 do relatório, focado nos casos de mortes e desaparecimento, foi realizado um exame cuidadoso das conclusões da CEMDP, bem como dos documentos constantes dos processos administrativos abertos por iniciativa de familiares das vítimas.

$\mathrm{Na}$ apresentação do relatório, os comissionados asseveram que a CNVse empenhou em efetivar o direito à memória e à verdade histórica e em promover a reconciliação nacional, "buscando fazer de nossa missão fator de mobilização da sociedade brasileira na defesa e na promoção dos direitos humanos" (CNV, 2014h, p. 15). O texto também ressalta bastante a importância do direito e das instituições internacionais relacionadas aos direitos humanos, inserindo-se nos marcos legais, de atividades e de interpretações traçados neste nível. E a Comissão se reconhece também como inserida no

\footnotetext{
${ }^{30}$ Em Direito à memória e à verdade, a CEMDP relata que avaliou 475 casos de morte e desaparecimento, sendo que, deste total, 136 já haviam sido reconhecidos pelo anexo da própria Lei 9.140/1995, 221 pedidos de reparação foram deferidos e outros 118 foram indeferidos, além do fato de que, mais tarde, aquela Comissão descobriria que um dos casos reconhecidos pelo anexo da lei tratava-se, na verdade, de pessoa que havia morrido em decorrência de causas naturais. Por isso, na CEMDP, dos 475 casos analisados, 356 foram plenamente reconhecidos. Já a Comissão da Verdade viria a reconhecer 434 casos de morte e desaparecimento decorrentes da repressão política.
} 
campo da justiça de transição: “A CNV situou o Brasil entre as dezenas de países que, diante de múltiplos mecanismos da Justiça de Transição, criaram uma comissão da verdade para lidar com o legado de graves violações de direitos humanos" (CNV, 2014h, p. 21). Em seguida, o texto traça também uma apologia da Lei 12.528/2011, que estaria em sintonia com as mais bem sucedidas comissões da verdade, pois teria conferido à Comissão um "marco normativo abrangente" (CNV, 2014h, p. 22).

O texto também fala de amplas cooperações com outras comissões da verdade no Brasil e da "ampla mobilização" que a CNV teria conseguido fazer na sociedade brasileira durante seu funcionamento. Em seu entendimento, atividades realizadas em conjunto com outras comissões deram ampla capilaridade aos trabalhos da CNV, o que é essencial em país de dimensões continentais como o Brasil. Reconhecendo-se como parte de uma história de luta por verdade e justiça, o relatório final relembra os movimentos brasileiros por anistia, as greves de fome praticadas por presos políticos contra as torturas, execuções e desaparecimentos e os protestos contra o projeto de anistia do governo Figueiredo. $\mathrm{O}$ texto também se reporta à sentença da Corte Interamericana no caso Guerrilha do Araguaia e especialmente à sua recomendação de criação, por parte do Estado brasileiro, de uma comissão da verdade.

Segundo o relatório, "CNV foi regida pelo princípio da publicidade, na medida em que suas atividades sempre que possível foram públicas, excetuando-se as situações em que, a seu critério, a manutenção de sigilo foi relevante para o alcance de seus objetivos ou para resguardar a intimidade, a vida privada, a honra ou a imagem de pessoas" (CNV, 2014h, p. 43).Entretanto, seria pertinente se a Comissão dispusesse a informação sobre a proporção entre depoimentos públicos e depoimentos tomados sob sigilo ou mediante preenchimento de formulários, que parecem ter sido a maioria dos casos.Com relação às audiências públicas, sua transmissão via internet de fato possibilitou que os testemunhos tomados de forma pública pudessem ser amplamente acompanhados por milhares de pessoas em todo o país.

O Volume 1 do relatório, assinado pelos seis membros remanescentes do colegiado, trata das atividades da $\mathrm{CNV}$, das graves violações aos direitos humanos, conclusões e recomendações. Visa a atender de forma estrita, segundo a própria Comissão, seus desígnios definidos por sua lei. A primeira parte do volume 1 se ocupa da criação e das atividades da CNV; a segunda, das estruturas do Estado e das graves violações aos direitos humanos, com sua contextualização, características e as articulações da ditadura brasileira com outras estruturas repressivas do Cone Sul. O capítulo 3, intitulado 
“Contexto histórico das graves violações entre 1946 e 1988”, traz uma linha do tempo que mapeia o contexto político que teria permitido a prática das graves violações de direitos humanos. Um capítulo também foi dedicado ao retrato do monitoramento, pelo regime militar, das atividades dos brasileiros exilados, refugiados e banidos, por meio, principalmente, do Centro de Informações do Exterior (Ciex), ligado ao Ministério das Relações Exteriores em coordenação com o Serviço Nacional de Informações (SNI). Outro capítulo tratou da cooperação internacional para ações de repressão, em especial a Operação Condor, que uniu forças de segurança e serviços de inteligência das ditaduras do Cone Sul. Segundo atesta o próprio relatório, a CNV foi a primeira comissão da verdade dos países que foram objeto da Operação Condor a dedicar-se a investigar de forma mais detida o que denominou de "terrorismo de Estado", como definido pela própria Corte Interamericana de Direitos Humanos ao tratar da Operação (Cf. CNV, 2014h, p. 41).

A terceira parte do volume 1 se reporta aos métodos e práticas de graves violações coordenadas pelas forças de segurança com aval da cúpula do governo militar. Esta parte apresenta os conceitos de cada modalidade de violações e a descrição de sua prática. A quarta parte cuida dos chamados "casos emblemáticos". Ali a Comissão se dedica também à indicação dos responsáveis pelas violações: 377 agentes públicos foram identificados como perpetradores. O papel do Judiciário na repressão também é colocado sob enfoque crítico nesta parte. Já a quinta e última parte do volume 1 reúne as conclusões sobre o que foi apurado e as recomendações do colegiado para que as violações não se repitam.

Entre as principais das 29 recomendações estão: o reconhecimento, pelas Forças Armadas, de sua responsabilidade institucional pela ocorrência de graves violações de direitos humanos durante a ditadura militar (1964 a 1985); a responsabilização civil, administrativa e criminal dos agentes envolvidos nestas práticas; proibição de eventos comemorativos do golpe militar; reformulação dos concursos de ingresso nas Forças Armadas; modificação dos currículos das carreiras militares e policiais; criação de mecanismos de prevenção e combate à tortura; desvinculação das perícias criminais e dos institutos médicos legais das secretarias de segurança pública e das polícias civis; criação de ouvidorias externas no sistema penitenciário; revogação da Lei de Segurança Nacional; desmilitarização das polícias ostensivas estaduais; extinção da Justiça Militar estadual; eliminação, na legislação, da figura do auto de resistência à prisão (em que são computadas até hoje a maior parte das mortes de civis em decorrência da atuação das polícias); instituição de órgão permanente a dar seguimento às ações e recomendações da $\mathrm{CNV}$; prosseguimento e fortalecimento das políticas de localização e identificação de 
restos mortais de desaparecidos políticos e das políticas de abertura e sistematização de arquivos com informações sobre a ditadura militar.

Levando em conta o teor do relatório final e de suas recomendações, importa reconhecer que a CNV avançou o tensionamento sobre os desígnios tradicionais associados à anistia (embora a lei que a criou ainda a ligasse a seus contornos). Se nos termos tradicionais da anistia e da (re)conciliação nacional o esquecimento do passado de atrocidades aparecia como condição necessária para que Estado e sociedade mirassem o futuro de forma prospectiva, a CNV não só realçou a questão da verdade e da memória sobre aquele passado, mas passou a associá-la mesmo a uma das condições para a construção de um futuro mais justo, em que práticas de violações perpetradas por agentes públicos não poderão sair imunes. É neste sentido também que, ciente da continuidade de práticas repressivas especialmente pelas forças de segurança, a CNV recomendou a alteração de seus currículos, a desmilitarização das polícias ostensivas, entre outras sugestões. Mais do que isso, a atribuição de responsabilidades (que, como vimos no capítulo 1, difere da atribuição de penas) avançou mais uma diferença importante em relação aos desígnios tradicionais da anistia, tocando mesmo em um de seus pontos centrais atinentes à (re)conciliação: ainda que esta remanesça um dos objetivos centrais, ela precisará conviver com a atribuição de responsabilidades de agentes públicos, sendo que, ao contrário, em seu sentido tradicional, a (re)conciliação exigia não apenas o esquecimento do passado, mas também a garantia da falta de accountability de agentes da repressão.

Por outro lado, um dos predicados do sentido tradicional da (re)conciliação parece ter permanecido nos trabalhos da CNV: refiro-me a insistência de ela configurar-se como termo relacional entre agressores e vítimas, entre partidários do regime autoritário e opositores. Na medida em que o relatório final não possui uma característica analítica, este predicado pode ser extraído, por exemplo, de uma passagem em que a CNV considera o pedido de perdão das Forças Armadas às vítimas da repressão como indispensável à (re)conciliação nacional:

"Se é certo que, em função de questionamento da CNV, as Forças Armadas expressaram a ausência de discordância com a posição já assumida pelo Estado brasileiro diante desse quadro de graves violações de direitos humanos [...], é também verdadeiro que, dado o protagonismo da estrutura militar, a postura de simplesmente "não negar" a ocorrência desse quadro fático revela-se absolutamente insuficiente. Impõe-se o reconhecimento, de modo claro e direto, como 
elemento essencial à reconciliação nacional e para que essa história não se repita" (CNV, 2014h, p. 965).

Um acerto, ainda que mínimo, entre agressores e vítimas continua a ser "elemento essencial à reconciliação nacional", embora, como vimos, este acerto já não dependa do esquecimento do passado, mas de um pedido de um reconhecimento das violações cometidas.

O segundo volume do relatório é organizado segundo a descrição de violações a direitos humanos por segmento social, como os militares, trabalhadores, camponeses, igrejas cristãs, povos indígenas, homossexuais, professores e estudantes. O volume também traz capítulos dedicados ao retrato da resistência da sociedade civil à ditadura militar, bem como dos grupos que apoiaram e/ou colaboraram com o golpe e com a instauração do autoritarismo (há um capítulo que retrata especialmente o apoio do empresariado brasileiro à ditadura militar). No total, são nove textos subscritos por diferentes membros da CNV conforme os grupos de trabalho que coordenavam. Trata-se, portanto, de textos temáticos assinados não pela CNV em seu conjunto, mas por membros individuais.

O primeiro texto do volume 2 tem por objeto as violações a direitos humanos no meio militar e foi elaborado sob a responsabilidade da comissionada Rosa Maria Cardoso com a ajuda de uma equipe de pesquisadores. O segundo texto, também sob responsabilidade de Rosa Cardoso, cuida das violações aos direitos humanos experimentadas por trabalhadores. A sistematização deste texto contou com forte colaboração de um coletivo composto por representantes de dez centrais sindicais brasileiras, comissões e comitês estaduais e municipais da verdade, entidades, associações e centros de memória de trabalhadores. Já o terceiro texto do volume 2 tem por objeto as violações aos direitos humanos praticadas contra camponeses. Coordenado pela comissionada Maria Rita Kehl, este artigo contou com a colaboração, além dos pesquisadores da $\mathrm{CNV}$, de um grupo de pesquisadores da Universidade Federal de Minas Gerais reunidos em torno do chamado "Projeto República". O quarto texto, sob a coordenação do comissionado Paulo Sérgio Pinheiro, trata das violações praticadas pela repressão política contra as igrejas cristãs no país. Tendo como tema as violações praticadas contra povos indígenas, o quinto texto foi elaborado também sob a coordenação de Maria Rita Kehl. Para a redação deste tópico foi importante, destaca o relatório, a colaboração da Comissão da Verdade Indígena. As violações a direitos humanos nas 
universidades são objeto do sexto texto do volume 2 do relatório final da CNV. Também sob a coordenação da comissionada Rosa Maria Cardoso, para a redação deste artigo contribuíram comissões da verdade universitárias das seguintes instituições: Fundação Escola de Sociologia e Política de São Paulo, PUC/SP, UnB, Unesp, Unicamp, Unifesp, UFBA, UFC/UECE, UFES, UFPA, UFPR, UFRJ, UFRN e USP. Paulo Sérgio Pinheiro também coordenou o GT sobre as violações praticadas pela repressão política contra homossexuais, que redigiu o sétimo texto do segundo volume do relatório. Este texto também contou a colaboração de pesquisadores externos. $\mathrm{O}$ penúltimo artigo do segundo volume, também sob a coordenação de Rosa Maria Cardoso, trata dos grupos de civis que colaboraram com a ditadura. Já o nono e último texto cuida da resistência de grupos da sociedade civil às violações a direitos humanos. Assinado pela comissionada Maria Rita Kehl, este artigo foi redigido por uma das pesquisadoras mais destacadas da CNV, a historiadora Heloisa Starling, em colaboração com outros pesquisadores da Comissão.

$\mathrm{O}$ terceiro volume do relatório final da $\mathrm{CNV}$ apresenta um relato circunstanciado dos casos de morte e desaparecimento forçado ocorridos em função da atuação de agentes da repressão, bem como identifica mais uma vez aqueles que seriam os responsáveis imediatos e mediatos dos crimes praticados contra as vítimas. A CNV entendeu como violadores de direitos humanos não apenas os agentes diretamente envolvidos nas condutas criminosas, mas também aqueles que, em diferentes posições hierárquicas, contribuíram para viabilizar, planejar ou mesmo coordenar estas práticas.

Além disso, a fim de tentar redimir algo da história pessoal destas vítimas, o volume traz um relato mais detalhado sobre a biografia de cada uma delas, em relação àquele já introduzido no livro Direito à memória e à verdade, publicado pela CEMDP em 2007. A estrutura dos perfis dos mortos e desaparecidos reconhecidos foi dividida em oito partes, com dados pessoais, biografia, considerações sobre investigações anteriores à instituição da CNV, circunstância da morte ou desaparecimento, identificação do local e da autoria do crime, bem como das fontes principais de investigação da Comissão. Foram reconhecidos 434 mortos e desaparecidos políticos, número que frustrou muitos dos grupos atuantes no campo da memória, verdade e justiça, que esperavam ver um número significativamente maior, caso fossem incluídos muitos dos camponeses e indígenas que suas respectivas comissões da verdade insistiam terem sido mortos ou desaparecido em função da atuação do Estado repressivo. Nos termos do próprio volume 3 do relatório final:

"Para a produção do presente volume, a CNV buscou consultar grande 
parte dos acervos disponíveis, ouvir ex-presos, sobreviventes de tortura, familiares e agentes da repressão, mas mesmo com o esforço dispensado durante os trabalhos não foi possível desvendar a maior parte dos casos de mortes e desaparecimento ocorridos durante os anos de 1964 a 1988. As lacunas dessa história de execuções, tortura e ocultação de cadáveres de opositores políticos à ditadura militar poderiam ser melhor elucidadas hoje caso as Forças Armadas tivessem disponibilizado à $\mathrm{CNV}$ os acervos do CIE, CISA e Cenimar, produzidos durante a ditadura, e se, igualmente, tivessem sido prestadas todas as informações requeridas, conforme relatado no capítulo 2 do volume 1 do Relatório da CNV. As autoridades militares optaram por manter o padrão de resposta negativa ou insuficiente vigente há cinquenta anos, impedindo assim que sejam conhecidas circunstâncias e autores de graves violações de direitos humanos ocorridas durante a ditadura militar" (CNV, 2014j, p. 28-29).

A CNV concluiu que as violações aos direitos humanos praticadas pelo aparato repressivo montado a partir da instauração da ditadura militar foram sistemáticas, o que as qualificaria como crimes contra a humanidade. Nos termos do relatório: "Ao debruçar-se sobre as graves violações de direitos humanos praticadas entre 1946 e 1988, a CNV não se deparou com atos isolados, mas, no curso do regime militar, com prática disseminada em larga escala." E um pouco mais adiante: "Uma vez que as graves violações examinadas foram praticadas em um contexto sistemático e generalizado de ataque contra a população civil, como resta demonstrado neste Relatório final, a CNV concluiu, em diversas ocasiões, ter havido a ocorrência de crimes contra a humanidade" (CNV, 2014h, p. 40).

O relatório final foi de fato redigido de forma bastante minuciosa, além de ter sido em geral muito bem escrito. Configura-se, assim, como um importantíssimo legado da $\mathrm{CNV}$ e reafirma de forma mais contundente a refutação, pelo próprio Estado brasileiro, do antigo negacionismo histórico do próprio Estado. A maior falha do processo, entretanto, como destacado por vários grupos engajados na pauta, foi a metodologia pouco participativa dos trabalhos da Comissão. Veremos mais sobre esta crítica no tópico a seguir.

\subsection{2) Repercussão do relatório final}

Tratando-se de uma comissão da verdade, a questão da repercussão de seus trabalhos e sua capacidade ou não de realçar o tema no debate público nacional são absolutamente centrais e fazem parte de seus principais objetivos e mesmo da razão de ser destas comissões. Diferentemente do que acontece, por exemplo, com as decisões da 
Suprema Corte, as quais, embora no caso do controle concentrado de constitucionalidade ganhem forte repercussão e muitas vezes um debate mais amplo, este não é um de seus desígnios principais. Isto porque, quando a Suprema Corte se manifesta, sua palavra já é ato, isto é, sua manifestação é ao mesmo tempo uma determinação. Já nas comissões da verdade, seu sucesso é medido não só pela qualidade das pesquisas, testemunhos que tomou, diligências periciais que realizou ou mesmo pelo nível de detalhamento e precisão de seu relatório final, mas também por sua capacidade de afetar um debate público mais amplo. Veremos a seguir repercussões da atuação da CNV em basicamente três nichos: os principais veículos de comunicação, entidades da sociedade civil engajadas na área dos direitos humanos e as Forças Armadas.

Conforme foi ressaltado no começo deste capítulo, o que há de mais completo até o momento em termos de balanço dos trabalhos da CNV são os relatórios de acompanhamento das atividades da Comissão redigidos pelo ISER, especialmente seu quinto e último relatório de acompanhamento. Este último relatório do ISER foi muito importante, sobretudo, para me ajudar a mapear as repercussões dos trabalhos da CNV nos três nichos mencionados acima. O ISER inclusive promoveu uma pesquisa qualitativa com entidades da sociedade civil atuantes na área dos direitos humanos no sentido de avaliar as atividades da $\mathrm{CNV}$.

Nesta pesquisa, as entidades que responderam aos questionários do ISER criticaram especialmente a baixa participação da sociedade civil nos cerca de 30 meses de funcionamento da Comissão. Segundo o ISER, esta crítica se tornou ainda mais evidente a propósito da divulgação do relatório final, em que a presença dos coletivos engajados no campo da memória, verdade e justiça, dos familiares de presos e desaparecidos políticos e dos movimentos sociais, de uma forma geral, foi bastante restrita (Cf. ISER, 2015, p. 10). O Instituto também reclamou das respostas vagas, em sua avaliação, às solicitações de informações que fez à CNV com base nos parâmetros da Lei de Acesso à Informação, a qual, aliás, como vimos, foi criada em compasso com a própria $\mathrm{CNV}$.

$\mathrm{Na}$ estrutura da Comissão brasileira, vemos sua composição sendo formada, em sua grande maioria, por pesquisadores da área de ciências humanas, com professores e pós-graduandos ou recém-doutores formados em cursos de história, direito, ciência política, entre outros. Esta composição refletiu-se nos próprios trabalhos, bastante engajados que foram numa reconstrução minuciosa das violações aos direitos humanos a partir de diferentes aspectos (como a estrutura autoritária, a repressão a segmentos, grupos ou movimentos sociais, ou mesmo a partir de um ponto de vista em que a biografia das 
vítimas é acentuada) em três volumes de mais de 4 mil páginas no relatório final. Mas talvez, por outro lado, esta composição também possa ser parte da explicação sobre o motivo por que comissões de familiares de mortos e desaparecidos políticos e outros grupos da sociedade civil criticaram o processo de construção da memória e da verdade históricas sobre o período como tendo sido um tanto hermético. A preocupação em elaborar um relatório bastante criterioso (como de fato o foi) pode ser parte da explicação da pouca abertura da CNV à participação da sociedade civil no curso de seus trabalhos.

Como foi bem observado pelo ISER (2015, p. 80-81), no dia da apresentação do relatório final da $\mathrm{CNV}$ ou um dia depois, os principais jornais online (no primeiro caso) e impressos (no segundo) colocaram como manchete de maior destaque a cerimônia realizada na sede do Conselho Federal da OAB, mas ressaltavam em seus títulos especialmente a emoção e o choro da presidente Dilma Rousseff no evento. A listagem dos 377 agentes da repressão identificados como responsáveis direta ou indiretamente por torturas, assassinatos e desaparecimentos forçados também foi amplamente divulgada pela imprensa. Em relação a este tema em particular, aliás, a vice-procuradora da República, Ela Wiecko, sustentou que o relatório final da CNV dará suporte para as ações contra os torturadores que correm na Justiça Federal. Segundo ela:

"Para nós do Ministério Público, o relatório é muito importante porque gera consequências jurídicas. Além de um fato político, o relatório é um fato jurídico. Se trata de um relatório produzido por um órgão de Estado, com o rigor metodológico e que foi baseado em fatos comprovados e numa cadeia de elementos probatórios que permitiram conclusões". 31

Entretanto, os principais veículos formadores de opinião escreveram editoriais nos dias que se seguiram à apresentação do relatório da CNV posicionando-se fortemente contra a revisão da Lei de Anistia ou qualquer mecanismo que eventualmente redundasse na possibilidade de responsabilização penal de agentes da repressão. Em edital intitulado "Página Virada", a Folha de São Paulo, jornal de maior tiragem e com maior número de acessos online no país, por exemplo, manifestou-se neste sentido:

"Por mais que seus efeitos possam ser repugnantes do ângulo humanitário, sobretudo para os atingidos pela violência ditatorial, a anistia irrestrita é um dos pilares sobre os quais se apoia a democracia brasileira. Foi sua aceitação pelo conjunto das forças políticas que rompeu o ciclo de retaliações iniciado em 64. Não é sensato nem

\footnotetext{
${ }^{31}$ Ver a declaração em EBOLI, E. "Vice-procuradora da República diz que relatório da CNV dará suporte para ação contra torturadores”. O Globo. Rio de Janeiro, 11 dez. 2014. Caderno Brasil. Disponível em: http://oglobo.globo.com/brasil/vice-procuradora-da-republica-diz-que-relatorio-da-cnv-dara-suporte-paraacoes-contra-torturadores-14806902. Último acesso em 05 de maio de 2015.
} 
desejável que compromissos internacionais assumidos pelo Brasil, determinando que a tortura é crime imprescritível, possam sobrepor-se à soberania jurídica nacional quando se trata das próprias fundações do Estado de Direito entre nós". 32

A Folha reproduzia assim a imagem sobre a dimensão "fundacional" que teria a anistia no país, reiterando os principais aspectos do sentido tradicional da (re)conciliação (exceto a questão do esquecimento). O editorial de $O$ Globo, de 15 de dezembro de 2014, abordaria o tema de maneira semelhante:

"De forma oportunista, esses setores ainda tentam puxar para seus argumentos a suposta prevalência de tratados internacionais que condenam crimes como a tortura. Mas, como lembra o ministro do STF Marco Aurélio, eles não se sobrepõem à Constituição do país. A proposta de uma revisão da anistia, se pudesse ser lavada a sério, para um acerto de contas com o passado, embutiria também a punição, a posteriori, de militantes da esquerda envolvidos no assassinato de agentes públicos. Mas, por conveniência, o que o relatório final da CV propõe é uma aplicação unilateral da lei. Ou seja, pune-se apenas um lado da 'guerra suja'. De qualquer modo, a presidente Dilma teve uma reação positiva ao receber o documento, quando desoxigenou a ideia de o relatório dar margem a revanchismos". 33

O Globo, segundo jornal com maior tiragem no país, tentou colar a ideia de que teria havido uma "Guerra" durante a ditadura, para então justificar a defesa da chamada "teoria dos dois demônios", reiterando a ideia de que "os dois lados" teriam cometido erros igualmente condenáveis e que, por esta via, revogar a isenção de responsabilidade penal apenas aos militares seria algo "unilateral". Vale lembrar que ambos os jornais, assim como a maioria dos diários da época, apoiaram o golpe em 1964 e a ditadura em seus primeiros anos.

Pesquisas realizadas pelo ISER com comitês de memória, verdade e justiça mostraram que a maioria das avaliações sobre os trabalhos da CNV, pelo menos desde uma discussão entre estes grupos, não foi positiva (Cf. ISER, 2015, p. 138-39). Na avaliação geral sobre o primeiro ano de funcionamento da CNV sobressaiu a crítica sobre a falta de uma metodologia consistente, o que foi reiterado no segundo ano: as frustrações sobre o desempenho da Comissão foram novamente atribuídas à falta de um planejamento anterior. Em linhas gerais, segundo o ISER (2015, p. 140), os comitês também ressaltaram

\footnotetext{
${ }^{32}$ Ver "Página virada". Folha de São Paulo. São Paulo, 12 dez. 2014. Editorial. Disponível em: http://www1.folha.uol.com.br/opiniao/2014/12/1561252-editorial-pagina-virada.shtml. Último acesso em 12 de maio de 2015.

${ }^{33}$ Ver "Ampla e irrestrita". O Globo. Rio de Janeiro, 15 dez. 2014. Editorial. Disponível em: http://oglobo.globo.com/opiniao/ampla-irrestrita-14822807. Último acesso em 12 de maio de 2015.
} 
que "a CNV não é muito receptiva às demandadas da sociedade civil e não foi transparente durante a maior parte de seu trabalho". Além disso, os comitês consideraramna pouco permeável e muito centralizadora, tendo se fechado a uma participação mais ampla. Entre algumas das respostas aos questionários do ISER selecionadas para seu último relatório de acompanhamento, lê-se sobre a CNV: "Receptividade enigmática, sem posições claras, exceção para pessoas isoladas" (ibid. id.).

Segundo o ISER (2015, p. 167), parte significativa das respostas críticas a respeito do funcionamento da CNV partiu de observações sobre o próprio projeto de lei que a criou, suas limitações e restrições, principalmente as relacionadas à ideia de "reconciliação nacional" e à submissão da CNV aos parâmetros da Lei de Anistia. Também foram destacadas as críticas sobre o pouco tempo de funcionamento da instituição frente ao longo período que deveria ser analisado. Outros problemas relacionados ao desenho da Lei 12.528/2011, tais como o número de comissionados e membros, o orçamento e a impossibilidade de punição aos perpetradores de graves violações a direitos humanos também foram ressaltados nas respostas ao ISER.

Algumas das organizações consultadas chamou atenção ainda para os problemas de divergências internas entre membros da CNV. Para uma delas, a "ausência de regras claras para o funcionamento da Comissão" tornou-se a "principal causa de desentendimento entre os seus membros". Neste sentido, conclui o ISER (2015, p. 16869):

"podemos indicar que a estrutura institucional da CNV foi apontada como um dos motivos para os problemas operacionais da Comissão: 'presidência rotativa, mudança constante na secretaria executiva, saída e entrada de novos membros'. Também foram tratados como pontos negativos as 'divergências públicas entre os integrantes sobres os rumos dos trabalhos da Comissão', a 'dificuldade de resolver conflitos internos' e a 'péssima interação entre os comissionados'."

Por outro lado, em suas manifestações sobre o relatório final da CNV dirigidas ao público em geral, organizações da sociedade civil com expressiva atuação no campo dos direitos humanos marcariam uma posição bastante diferente da veiculada pelos principais meios de comunicação. A Anistia Internacional, por exemplo, divulgou uma nota considerando a apresentação do relatório final da CNV como um "momento histórico", e que o documento configura um passo importante para que o país faça justiça aos crimes 
cometidos por agentes públicos durante a ditadura militar. ${ }^{34}$ A nota ressaltou também que a demonstração sobre o caráter generalizado das violações de direitos humanos pode resultar em que a Lei de Anistia deixe de ser obstáculo à necessária punição penal dos responsáveis. A Anistia Internacional ainda chamou a atenção para o destaque dado pela $\mathrm{CNV}$ às violações sobre povos indígenas e trabalhadores rurais, mas ressaltou a necessidade de se aprofundar as pesquisas e o reconhecimento de violações contra estas populações. Por fim, a organização destacou também a relação que a CNV tentou estabelecer entre a impunidade de agentes públicos do passado e a continuidade de violações praticadas por agentes públicos no presente. No mesmo sentido, considerando a importância histórica do momento, a Conectas Direitos Humanos publicou em seu site matéria sobre o fim da $\mathrm{CNV}$ e a publicação de seu relatório final, como o "mais importante documento já produzido no Brasil sobre violações de direitos humanos sobre a ditadura militar", que pode "abrir caminho para enfrentar violações de direitos humanos do presente". 35

As reações das Forças Armadas e do Ministério da Defesa eram também bastante aguardadas. Em função do histórico de não colaboração das Forças Armadas com o processo de investigação da $\mathrm{CNV}$ e às constantes declarações de seus membros contra a sua criação, já era esperada por grupos e instituições que militam e atuam no campo a repercussão negativa do relatório final da Comissão entre boa parte dos militares. Os Clubes Militares até hoje comemoram aniversários do golpe de 1964; e vemos ainda muitas declarações de comandantes das três forças não reconhecendo as violações do passado ou classificando-as como justas em um contexto de "Guerra". Carlos Alberto Brilhante Ustra, assim como outros militares ou familiares, publicaram livros também tentando dar conta de sua versão sobre a repressão, especialmente destacando a violência e o "terrorismo" dos grupos armados e tentando caracterizar uma verdadeira ameaça de revolução socialista ou comunista nos anos 1960 e 1970 no país. ${ }^{36}$

Com o lançamento do relatório final, diversas foram as declarações e notas contrárias ao processo político e institucional da $\mathrm{CNV}$, com visões revisionistas e

\footnotetext{
${ }^{34}$ A nota pode ser lida no seguinte endereço eletrônico: https://anistia.org.br/noticias/nota-publica-relatoriofinal-da-comissao-nacional-da-verdade-da-passo-importante-para-garantir-o-direito-memoria-verdade-ejustica/. Último acesso em 05 de maio de 2015.

${ }^{35} \mathrm{O}$ texto da Conectas sobre o relatório final da CNV pode ser lido no seguinte endereço eletrônico: http://www.conectas.org/pt/acoes/justica/noticia/26595-um-passo-historico. Último acesso em 05 de maio de 2015.

${ }^{36}$ Em clara referência à sua oposição aos grupos e instituições que militam no campo da justiça de transição no Brasil e àquela que seria uma futura instalação de uma comissão da verdade no país, o livro de Ustra (2011) é intitulado $A$ verdade sufocada.
} 
negacionistas que focam na responsabilização de "terroristas". Em nota, o Clube Militar (que representa os militares da reserva), escreveu:

"A finalidade da CNV, desde sua concepção, sempre foi uma só: alterar a Lei de Anistia parcialmente, de maneira que os agentes do Estado, que combateram e venceram as tentativas comunistas de tomada do poder no Brasil, não sejam protegidos pela dita Lei. Quanto aos angelicais terroristas, merecem toda a proteção e indenizações criadas ou a criar. O relatório só poderia ser uma coleção de meias verdades, calúnias e mentiras inteiras, embaladas com pedaços de verdade cuja divulgação confirme a orientação socialista dos comissários. [...] Três volumes e mais de duas mil páginas [são, na verdade, mais de quatro mil páginas]: um relatório que não apresenta grandes novidades e, em suas recomendações, insiste na adoção de medidas que implicam a retroação de leis para prejudicar o pretenso réu, a subordinação do ordenamento jurídico nacional às decisões de agências internacionais, e a absurda sugestão de que aos acusados não sejam aplicados a Lei da Anistia ou quaisquer outras disposições constitucionais ou legais que possam beneficiá-los". ${ }^{37}$

O Clube Naval também publicou nota de repúdio ao relatório da $\mathrm{CNV}$, que foi publicada pelo jornal O Estado de São Paulo. Nela lê-se:

"Montanha também de levianas generalidades e de inconsistentes tentativas de enxovalhar biografias de ilustres brasileiros, uma grande parte já falecida, sem possibilidades de se defender. [...]Por tudo isso e por entender o relatório da Comissão Nacional da Verdade como ilegal, parcial e divorciado da realidade, o Clube Naval repele com total veemência a referência, como criminosos, a consagrados chefes navais, homens de conduta ilibada, verazes e líderes exemplares, que sempre nos ofereceram sólidos exemplos de profissionalismo e probidade no trato da coisa pública, qualidade tão carente nas elites nacionais de hoje". 38

Houve também reações individuais de militares citados entre os perpetradores e familiares. Neste sentido, por exemplo, o repúdio da família do general Etchegoyen ao relatório da $\mathrm{CNV}$ foi publicado pelo jornal O Estado de São Paulo.

Por outro lado, nota em tom bem diferente foi exarada pelo comandante da Marinha, o almirante de esquadra Júlio Soares Moura Neto, que em sua declaração informou basicamente que aguardaria determinações da Presidência da República em relação às recomendações do relatório final da $\mathrm{CNV}$. $\mathrm{O}$ almirante disse, ainda, que a

\footnotetext{
${ }^{37}$ A nota, assinada pelo general aposentado Gilberto Rodrigues Pimentel, presidente do Clube Militar, pode ser obtida no seguinte endereço eletrônico: http://clubemilitar.com.br/pensamento-do-clube-militar-14/. Último acesso em 05 de maio de 2015.

${ }^{38}$ Ver TOSTA, W. "Clube Naval diz que relatório da Comissão da Verdade é 'ilegal". Jornal Estadão. São Paulo, 11 dez. 2014. Caderno Política. Disponível em: http://politica.estadao.com.br/noticias/geral,clubenaval-diz-que-relatorio-da-comissao-da-verdade-e-ilegal,1605590. Último acesso em 05 de maio de 2015.
} 
Marinha analisará o relatório de onde "possivelmente sairão algumas orientações e determinações", e que a "Comissão cumpriu seu papel". ${ }^{39}$

Já o Ministro da Defesa, embora homem forte do partido da presidente, pronunciou-se de forma bastante diplomática a respeito do relatório final da CNV, parecendo não querer se indispor com as Forças Armadas. Segundo o ministro:

"Não vim aqui com nenhuma lanterna na mão para procurar passado. Vim aqui para olhar para frente, para valorizar as Forças Armadas. Ninguém fugirá à interpretação da história. [...]

Cinquenta anos se passaram e não há porque ficarmos colocando nenhum tipo de obstáculo ao que temos pela frente. Ainda assim, as recomendações serão processadas." 40

\section{Considerações finais do capítulo}

A questão da baixa participação da sociedade civil na conformação e nas atividades da CNV talvez tenha sido o principal problema no processo. Isto porque, se a Comissão da Verdade, como dissemos no início do capítulo, tem entre suas principais funções a tarefa de desempenhar uma interlocução entre a sociedade civil e o Estado, se a participação da sociedade civil em seu funcionamento é baixa, uma parte de seus desígnios principais resta comprometida. A este respeito, como vimos no tópico anterior, boa parte das organizações engajadas em direitos humanos que responderam aos questionários do ISER destacou o que pode ser resumido por uma das citações selecionadas pelo instituto: "o funcionamento da $\mathrm{CNV}$ se caracterizou por ser muito pouco aberto à participação da sociedade civil, sendo baixo o nível de diálogo existente até mesmo com ex-presos políticos e familiares de mortos e desaparecidos políticos" (ISER, 2015, p. 174).

Por outro lado, as mesmas entidades não deixaram de ressaltar que o engajamento da CNV foi capaz de realçar o tema da memória, verdade e justiça ao topo da agenda de discussões políticas desde sua instalação e sobretudo durante seu último ano de

\footnotetext{
${ }^{39}$ Ver TOMAZELLI, I. "CNV cumpriu papel e seu relatório será analisado, diz comandante da Marinha". Jornal Estadão. São Paulo, 12 dez. 2014. Caderno Política. Disponível em: http://politica.estadao.com.br/noticias/geral,cnv-cumpriu-papel-e-relatorio-sera-analisado-diz-comandanteda-marinha, 1606074. Último acesso em janeiro de 2015.

${ }^{40}$ Ver RODRIGUES, A. "Wagner garante que Defesa dará encaminhamento às recomendações da CNV". Agência Brasil. Brasília, 2 jan. 2015. Política. Disponível em: http://agenciabrasil.ebc.com.br/politica/noticia/2015-01/wagner-garante-que-defesa-dara-encaminhamentorecomendacoes-da-cnv. Último acesso em 04 de maio de 2015.
} 
funcionamento, em 2014. Neste sentido, alguns comentários apresentados aos questionários do ISER chamaram a atenção para o fato de que a instalação da $\mathrm{CNV}$ e a ampla divulgação de seus trabalhos (especialmente a partir de seu segundo ano de funcionamento) certamente contribuíram, por exemplo, para que vários Estados, municípios e entidades da sociedade civil criassem suas próprias comissões da verdade, num processo em que as comissões puderam, apesar de alguns atritos, intercambiar informações, documentos, experiências e suporte técnico. Isto também permitiu, como vimos, que a agenda da memória, verdade e justiça ganhasse maior capilaridade num país de dimensões continentais como o Brasil. ${ }^{41}$

Neste sentido, é igualmente importante dizer que, embora críticos à recomendação de responsabilização de agentes da repressão no relatório final da $\mathrm{CNV}$, muitos dos principais jornais do país produziram, durante o funcionamento da Comissão, cadernos especiais e páginas na internet dedicadas a um resgate histórico sobre o período da ditadura militar. O debate foi bastante intenso também em muitas universidades, sindicatos e movimentos rurais que, em muitos casos, criaram suas próprias comissões da verdade.

\footnotetext{
${ }^{41}$ Mas a apresentação do relatório final da CNV teve que dividir espaço nos principais jornais com as conturbadas eleições (especialmente presidenciais), a crise econômica que se acentuava no segundo semestre de 2014 e, sobretudo, com a deflagração da chamada "Operação Lava Jato", em que a Polícia Federal, o MPF e a Justiça Federal descobriram esquema bilionário de corrupção na Petrobrás envolvendo, inclusive, alguns políticos ligados à base aliada do governo e o tesoureiro do partido da presidente. No dia 10 de dezembro de 2014, a divulgação do relatório final da CNV foi a principal manchete dos principais veículos de comunicação do país, mas um dia antes e já no dia seguinte, as manchetes se relacionavam àquele escândalo de corrupção. Na conjuntura de recepção do relatório, porém, houve a coincidência de outro fator que pode ter ajudado a mitigar imputações sobre "revanchismo" e acusações análogas que pautaram algumas das reações à $\mathrm{CNV}$ no curso de seu funcionamento: refiro-me à divulgação, exatamente um dia antes da apresentação do relatório da CNV, do mais completo relatório produzido pelo Estado norte-americano (mais especificamente pelo Senado do país) sobre as torturas praticadas sistematicamente pela CIA (Central Intelligence Agency) com base em legislação permissiva, editada ainda durante o governo Bush, a violações a direitos humanos. As discussões em torno deste relatório, tendo se dado de forma praticamente concomitante ao relatório da Comissão brasileira, podem ter ajudado a azeitar a recepção do relatório final da CNV. A respeito desta legislação e das violações praticadas pela CIA nos últimos anos, cf. o relatório do Senado intitulado Committee Study of the Central Intelligence Agency's Detention and Interrogation Program (US Senate, 2014) e Alfred McCoy (2012).

Por outro lado, é preocupante que, poucos meses depois do fechamento dos trabalhos da Comissão, um dos três principais grupos que organizaram aquele que seria considerado o maior protesto público realizado na cidade de São Paulo desde as Diretas Já dispunha entre suas principais reivindicações uma intervenção militar no governo. O protesto foi realizado em 15 de março de 2015 e, embora pesquisa do Datafolha indique que mais de $80 \%$ dos manifestantes avaliasse a democracia como sendo sempre a melhor forma de governo, na manifestação, um dos grupos organizadores, além de pedir o impeachment da presidente Dilma Rousseff, exaltou o papel das Forças Armadas durante a ditadura militar e celebrou o que considerava como alguns de seus heróis da época. Entre eles estava Carlos Alberto Augusto, que, conforme detalhado no capítulo anterior, trabalhou durante o período militar com o hoje coronel da reserva Carlos Alberto Brilhante Ustra no DOI-CODI e com o delegado Fleury em São Paulo. Atualmente, Augusto é delegado da ativa da Polícia Civil do Estado de São Paulo. No dia 12 de abril, os mesmos grupos organizaram novos protestos massivos contra o governo em todo o país, mas com adesão menor de manifestantes. A questão sobre se estes movimentos terão ou não continuidade e força com o passar do tempo é ainda incerta.
} 
Nas palavras do ISER (2015, p.180):

"De um modo geral, tais organizações demonstraram que, apesar de todos os limites impostos pela própria metodologia adotada pela $\mathrm{CNV}$ (ou mesmo pela ausência de uma definição mais clara quanto a esses parâmetros), houve avanços significativos no campo da construção de uma memória social em relação ao período da ditadura nesse país, o que causou um impacto, de algum modo, significativo em todas as lutas e pautas do campo dos Direitos Humanos."

Outra contribuição importante dos trabalhos da CNV diz respeito a seu esforço de dar tanto uma dimensão coletiva quanto individual ao direito à verdade. Do ponto de vista da dimensão individual do direito, especialmente o volume 3 do relatório final apresentou um esclarecimento circunstanciado dos casos de violações aos direitos humanos praticadas contra mortos e desaparecidos políticos, além de ter promovido também a responsabilização individual de agentes públicos envolvidos direta ou indiretamente (mediante o comando das operações) com as graves violações aos direitos humanos. Isto não impediu, contudo, que a CNV também traçasse uma dimensão coletiva da verdade, no volume 1 a partir de uma reconstrução sobre a estrutura da repressão, e, no volume 2, a partir de relatos sobre violações que atingiram grupos sociais específicos.

Em "Responsabilidade pessoal sob ditadura", Hannah Arendt procurou distinguir entre explicar e justificar, cuja confusão terminológica poderia ter dado ensejo a boa parte das controvérsias sobre seu livro Eichmann em Jerusalém. As grandes explicações filosóficas sobre eventos históricos, diz a autora, na medida em que condenam "toda a humanidade", toda a sociedade ou algo do tipo, tendem a dar a impressão de uma isenção de responsabilidade pessoal dos sujeitos. Afinal, "quando todos são culpados, ninguém o é” (Arendt, 2004, p. 83). De modo análogo, a "culpa coletiva” disseminada em alguns setores da Alemanha no pós-guerra também dissolvia a culpabilidade pessoal daqueles que realmente cometeram alguma violação (Arendt, 2004, p. 89).

Quando se reconhece que no nazismo cada pessoa era descartável, sem que o sistema se alterasse, de acordo com Arendt, isso não significaria dizer, contudo, que, em função da fungibilidade das pessoas, elas seriam também individualmente irresponsáveis por seus atos. Apenas do ponto de vista da análise do sistema político valeria a afirmação "se eu não tivesse feito, outra pessoa o faria", mas não para isentar alguém de sua responsabilidade (Cf. Arendt, 2004, p. 93).

Neste mesmo texto, Arendt (2004, pp. 100 e seguintes) ressalta que os argumentos atinentes ao "ato de Estado" ou às "ordens superiores" também não seriam aplicáveis à 
avaliação dos comportamentos e à justificação das ações daqueles que, em algum nível, tomaram parte nas violações cometidas durante o nazismo. O "ato de Estado", análogo à legítima defesa, seria justificável enquanto exceção à lei exatamente para fazê-la voltar a valer. Na Alemanha nazista, ao contrário, a legalidade foi exasperada em função das arbitrariedades dos altos-comandos. Com relação às "ordens superiores", esta justificativa nada mais seria do que o símbolo mais bem acabado da obediência (ou da incapacidade de se servir do próprio pensamento) de muitas das pessoas envolvidas com as violações.

Isto significa que o fato de as violações terem sido sistemáticas e coordenadas pelo Estado repressivo não implica, como argumentam alguns defensores da anistia para os agentes públicos no Brasil, que estes estariam agindo meramente em função das ordens superiores e que isto os isentaria de responsabilidade. O fato de um "ismo" ser condenável (no caso, não o totalitarismo, mas o autoritarismo ${ }^{42}$ ) não torna menos condenáveis os indivíduos que participaram de atos de atrocidade em seu nome. Neste ponto, embora não tenha realizado um empreendimento analítico a respeito, a forma como a $\mathrm{CNV}$ organizou o relatório final e a distribuição entre as dimensões coletiva e individual da verdade e das responsabilidades foram bastante equilibradas.

Assim como a própria CNV, o ISER e outras organizações atuantes na área dos direitos humanos se colocaram fortemente contra a investigação sobre "os dois lados", pois conectaram este desígnio necessariamente à "teoria dos dois demônios". De fato, esta relação parece bastante sugestiva quando uma comissão da verdade se limita a avaliar "graves violações" ou "crimes contra a humanidade". A CNV concentrou seus esforços na questão das graves violações, e menos na estrutura política, social e econômica que permitiu o golpe e sua instauração ou nas razões e visões de mundo daqueles que pegaram em armas para combater o regime militar. Se tivesse tomado este escopo mais abrangente como pelo menos igualmente central em relação à questão das violações estatais, talvez a avaliação dos "dois lados" não seria diretamente associada à "teoria dos dois demônios", pois ela não estaria conscrita a um exame com caráter retributivo e de atribuição de responsabilizações.

Mais do que isso, mesmo com relação aos crimes cometidos por membros da luta armada, poderia haver uma elaboração no sentido de caracterizar seu aspecto eminentemente político e muito distante de qualquer caracterização dos crimes contra a

\footnotetext{
${ }^{42}$ Observe-se que, embora Hannah Arendt sustente seus exemplos na experiência do nazismo no texto citado, o título Responsabilidade pessoal sob ditadura indica que a filósofa considerava que suas ponderações a respeito do tema extrapolavam as particularidades do totalitarismo, e se estendiam também, na sua opinião, a outras experiências autoritárias.
} 
humanidade, por exemplo, em função de faltar-lhes a sistematicidade. De todo modo, repiso aqui que uma avaliação mais rasa sobre a atuação da luta armada talvez não tenha contribuído muito para esclarecer e colocar em debate aspectos importantíssimos daquele período. Minha crítica, portanto, vai no sentido de lamentar os efeitos possivelmente positivos que poderia ter uma tal avaliação.

A Comissão da Verdade procurou com algum sucesso superar algumas destas limitações ao tratar, por exemplo, no volume 2 de seu relatório final, do apoio de grandes parcelas da sociedade civil ao golpe militar e aos primeiros anos da repressão política; quando, no volume 3 , cuidou de uma dimensão ampliada das biografias dos mortos e desaparecidos políticos; ou quando no volume 2 dedicou capítulo à resistência da sociedade civil às violações, fosse pela luta armada, fosse por vias institucionais da época. Ou ainda quando, no volume 1, tratou da estrutura da repressão, que não diz respeito apenas às violações propriamente ditas e tomadas em seu aspecto isolado, mas de uma organização político-estatal para a disseminação do medo e da opacidade da esfera pública.

Mesmo assim, nos termos do próprio desenho legal acerca de seus principais desígnios, todo o empreendimento investigativo e de divulgação e debate em torno dos resultados apresentados tinha como centro gravitacional a questão das graves violações aos direitos humanos. Estas foram também objeto do maior empenho de divulgação e debate por parte da CNV e o tema tratado pela Comissão que contou com maior cobertura da mídia, sendo, portanto, o que mais fortemente ganhou o debate público e a percepção sobre os objetivos e resultados dos trabalhos da CNV.

Este recorte pode estar relacionado em parte com o dimensionamento do papel do Estado em uma época em que o liberalismo guarda contornos de hegemonia do ponto de vista da teoria política. ${ }^{43}$ Como sustentamos ao final do capítulo 1 , a justiça de transição é um campo de políticas públicas (e jurisprudência) privilegiado para se avaliar elaborações que órgãos do Estado fazem a respeito dos fundamentos e dos limites políticos e morais acerca do desempenho da própria atividade estatal. Em outras palavras, a propósito da justiça de transição, entre outras coisas, órgãos do Estado desenvolvem um autoentendimento de suas funções e de seus contornos.

A "verdade", ainda mais a veiculada por órgãos do Estado e (como no caso brasileiro) ligados ao governo, já não pode mais aspirar uma pretensão de totalidade. Em

\footnotetext{
${ }^{43}$ A este respeito, cf., por exemplo, Francis Fukuyama (1992) e Perry Anderson (1994).
} 
outras palavras, o saldo "positivo" ou "construtivo" do empreendimento da Comissão da Verdade que se apresenta como recomendação ou como devir para a atuação estatal tem também um sentido essencialmente negativo: o dever de não-repetição. Isto é, positivamente, trata-se de lições ao Estado sobre que caminhos evitar e o que seria preciso preservar para impedir que as violações do passado tomem lugar mais uma vez (pelo menos em seu nível sistemático e enquanto política de Estado).

Também vimos neste capítulo que o desígnio da “(re)conciliação nacional" apareceria na Lei 12.528/2011 já em seu artigo primeiro constituindo, ao lado da efetivação do direito à verdade e à memória histórica, um dos principais objetivos da Comissão Nacional da Verdade. Sua relação com o sentido tradicional de uma (re)conciliação tal como formulado, por exemplo, a propósito do projeto de anistia do governo Figueiredo ou de boa parte dos ministros do STF que consideraram a ADPF 153 como improcedente no mérito em 2010 pode ser deduzida do fato de que a lei ressaltava no parágrafo $4^{\circ}$ do artigo $4^{\circ}$ que as atividades da Comissão não teriam caráter jurisdicional ou persecutório. Nenhuma das comissões do gênero de que se tem notícia possuíam caráter jurisdicional ou persecutório (Cf. Hayner, 2011), de modo que, inserindo-se inclusive terminologicamente no âmbito das comissões da verdade, não seria necessário à lei especificar este ponto. $\mathrm{O}$ fato de tê-lo feito, a meu ver, seria um indício de que, apesar do progressismo de muitos dos membros do GT montado para a sua constituição, o projeto de lei que criou a CNV ainda estava constrangido por alguns dos antigos contornos da anistia: atinentes à sua bilateralidade e à pertinência desta para a questão da (re)conciliação.

Por outro lado, desde a criação da lei, pelo menos um dos desígnios tradicionais do discurso da conciliação seria superado, o esquecimento. Antes também intimamente associado ao imperativo de apaziguamento, estabilidade e concerto de grupos que estiveram em atrito, o esquecimento passaria a dar lugar à valorização do direito à verdade e da ampliação do debate público em torno de uma memória crítica do período de autoritarismo. Este avanço da CNV viria no sentido de aprofundar um movimento já iniciado pelo Estado brasileiro desde meados dos anos 2000 por meio das comissões de reparação, como vimos no capítulo 2 .

Além disso, ao longo do desenvolvimento dos trabalhos da Comissão, muitos de seus membros que antes endossavam a antiga imunidade penal e administrativa de agentes da repressão (como, por exemplo, José Carlos Dias, José Paulo Cavalcanti Filho e Gilson Dipp) mudariam de posição e passariam a anuir ao propósito de dispor entre as principais 
recomendações elencadas no volume 1 do relatório (o mais propriamente institucional) a necessidade de julgamento e condenação daqueles agentes. Em contato com comitês de memória, verdade e justiça, com a Comissão de Familiares de Mortos e Desaparecidos Políticos e também pressionada por outras comissões da verdade e entidades da sociedade civil (nacional e transnacional) neste sentido, a CNV desafiaria mais este importante componente do sentido tradicional da (re)conciliação (isto é, a bilateralidade da anistia), provando que, de fato, nem todos os marcos estabelecidos em seu formato legal determinariam ao fim e ao cabo o conteúdo e a qualidade do desenvolvimento de seus trabalhos e de suas recomendações.

Apenas um dos elementos mais importantes do sentido tradicional da (re)conciliação, talvez justamente por não ter sido problematizado, parece ter continuado a estar presente nos trabalhos e no relatório final da comissão: refiro-me ao caráter relacional da conciliação entre agressores e vítimas ou entre defensores e opositores do regime militar. A conciliação ainda não seria plenamente elaborada, como nos termos de alguns dos textos teóricos explorados no capítulo 1, enquanto uma relação mais abrangente dos cidadãos entre si, que, a partir dos processos de accountability e preservação da memória, poderiam se reconhecer como pertencentes de uma mesma comunidade política, assumindo direitos e responsabilidades iguais. Ou mesmo como uma conciliação mais abrangente entre Estado e sociedade, também via reconhecimento das violações do passado. ${ }^{44}$ Como vimos no capítulo 1 , várias experiências justransicionais mostraram que a conciliação entre agressores e vítimas, além de não ser um pressuposto para a continuidade do desenvolvimento do Estado de Direito ${ }^{45}$, trata-se de um empreendimento que, na maioria das vezes, mostrou-se muito pouco frutífero.

\footnotetext{
${ }^{44}$ Embora, como já deixamos claro, este reconhecimento tenha acontecido, ele não foi associado à conciliação pelos trabalhos da Comissão, que insistiu em que esta poderia ocorrer apenas quando as Forças Armadas especificamente fizessem sua mea culpa.

${ }^{45}$ Para tanto basta que haja enforcement das regras fundamentais de convivência, pois nesta medida, embora discordem até mesmo mortalmente, fica claro que diferentes grupos ou indivíduos, seja qual for sua orientação política, por exemplo, são obrigados pelas mesmas regras fundamentais, o que deita o terreno para que, malgrado eles mesmos, sejam vistos como pertencentes a uma mesma comunidade política.
} 


\section{Considerações finais da tese}

"Na civilidade há qualquer coisa de coercitivo ela pode exprimir-se em mandamentos e sentenças". Sérgio Buarque de Holanda, Raízes do Brasil, p. 160.

Ao fim e ao cabo, vejo o desenvolvimento da justiça de transição no Brasil como uma espécie de capítulo do "longo caminho em direção ao Ocidente". Em Der lange Weg nach Westen, o historiador Heinrich August Winkler (2002) cuida deste tema na Alemanha a partir de uma história do pensamento e da política alemãs. Contudo, diferentemente da Alemanha, que se encontrava por séculos (não somente do ponto de vista geográfico, mas também político) num enclave entre o Ocidente e o Oriente próximo, o Brasil estaria em uma posição diametralmente oposta (embora análoga): entre o Ocidente ${ }^{1}$ e o "extremo Ocidente" (expressão do francês Alain Rouquié [1992] para designar a América Latina). No caso brasileiro, o "extremo Ocidente" poderia ser caracterizado pelos modos de convivência plasmados pelo ambiente rural e patriarcal que o cosmopolitismo de nossos dias atuais ainda não teria logrado superar por completo.

O desenvolvimento da justiça de transição no Brasil ainda é um processo em aberto. Como vimos no capítulo 3, boa parte das ações judiciais promovidas pela Ordem dos Advogados do Brasil (OAB), pelo Ministério Público Federal (MPF) e por familiares de mortos e desaparecidos políticos nas esferas civil e criminal ainda está em curso. Embora as reparações econômicas tenham praticamente chegado ao fim na Comissão Especial sobre Mortos e Desaparecidos Políticos (CEMDP) e a Comissão de Anistia já tenha assentado sua jurisprudência a respeito das mais variadas hipóteses de pedidos de

\footnotetext{
${ }^{1}$ Ainda que não tenha propriamente um lócus político-social específico, ele pode ser caracterizado, em linhas gerais, pela articulação de ideais liberais e republicanos em algo como uma democracia cosmopolita, isto é, que abre mão de parte de sua soberania em proveito da prevalência dos direitos humanos.
} 
reparação em seu âmbito de funcionamento, esta última Comissão ainda processa pedidos de anistia e continua sua atividade de vanguarda na preservação e problematização da memória sobre o passado de violações. A Comissão Nacional da Verdade (CNV), embora tenha encerrado seus trabalhos, também deixou uma série de recomendações que precisarão passar pelo crivo do governo federal e do Congresso.

De todo modo, tendo em conta os mais de 35 anos que se passaram desde a publicação da Lei de Anistia até hoje, é possível perceber, como espero haver demonstrado no curso desta tese, que a justiça de transição no Brasil teve no que nomeei de "discurso da conciliação nacional", em suas primeiras décadas, seu principal marco normativo. Tal como formulada essencialmente a partir de uma defesa do projeto de anistia do governo Figueiredo, a categoria da "conciliação nacional" possuía fundamentalmente três elementos essenciais. Primeiro a necessidade de se esquecer o passado de violações para a construção de um futuro pautado na harmonia social; segundo que deveria ser garantida a imunidade penal e administrativa dos "dois lados" (agentes da repressão e opositores, particularmente os envolvidos com a luta armada), sem o que "revanchismos" ou "vinganças" poderiam tomar lugar e ameaçar a estabilidade da transição política; e terceiro que a conciliação seria uma categoria relacional entre agressores e vítimas, entre defensores da ditadura em geral e opositores em geral, que precisariam se "perdoar" reciprocamente para que o país pudesse voltar a trilhar seu rumo em direção a uma democracia controlada.

Depois de ter pautado o projeto governista de anistia que acabou sendo aprovado pelo Congresso ainda sob o regime autoritário, o discurso da "conciliação nacional" em seus termos tradicionais apontados acima ganharia contornos de hegemonia no curso da transição, quando mesmo a coligação dos candidatos da oposição que formariam a Aliança Democrática alçariam a "conciliação nacional” para além dos limites da questão da anistia e, numa espécie de esgarçamento excessivo da categoria, torná-la-iam uma das principais bandeiras da transição rumo à democracia. ${ }^{2}$ Também vimos no capítulo 2 que muitas das demandas que passariam mais tarde a ser consideradas como elementos normativos do campo da justiça de transição ficaram ainda quase que restritas à luta de ex-perseguidos políticos e de familiares de mortos e desaparecidos nos primeiros anos da redemocratização.

\footnotetext{
${ }^{2}$ A Aliança Democrática, como vimos no capítulo 2, foi resultado de uma coligação entre a Frente Liberal (dissidência do governista PSD liderada por Sarney) e o PMDB (que indicaria Tancredo Neves como candidato da Aliança à presidência). Esta coligação derrotaria o candidato governista ainda via Colégio Eleitoral em 1985 e selaria assim a transição formal da ditadura militar para um governo civil.
} 
Apenas a partir de 1995 o Estado passaria a dar uma resposta parcial às demandas dos familiares com a edição da Lei 9.140/1995, que reconheceu desde logo a responsabilidade do Estado por mortes e desaparecimentos de alguns perseguidos políticos e que abriria a possibilidade de reconhecimento da morte e desaparecimento de outros via processos administrativos em que também seriam avaliados pedidos de indenização. No que se refere à questão da conciliação, no entanto, a própria lei abrangeria a categoria pela primeira vez em dispositivo legal alçando-a a "princípio" e associando-a à "pacificação nacional" em seu artigo segundo. Nestes termos, pelo menos inicialmente, ainda que os processos administrativos em que se avaliavam as violações pudessem ser em tese analisados por pesquisadores, por exemplo, eles não foram objeto de campanhas abrangentes de divulgação e problematização da memória sobre as atrocidades do regime militar. Além disso, embora alguns nomes de agentes da repressão tenham aparecido em alguns processos, neles não estava em questão a autoria dos homicídios e desaparecimentos forçados (sequestros), pois o foco era a comprovação do suplício sofrido, não a responsabilização dos perpetradores. Desta forma, os parâmetros centrais do sentido tradicional da conciliação não eram desafiados, com exceção do esquecimento, que, mesmo modesta e timidamente, era parcialmente relativizado a propósito dos processos administrativos reservados.

Algo parecido pode ser dito a respeito dos primeiros anos de funcionamento da Comissão Nacional de Anistia. Criada por medida provisória (de 2001) convertida em lei em 2002, a Comissão de Anistia tinha como sua principal tarefa, pelo menos até meados de 2007, basicamente desempenhar as funções previstas no dispositivo legal que a estabeleceu (Lei 10.559/2002), isto é, avaliar processos administrativos de concessão de anistia política e reparações econômicas aos perseguidos políticos do regime militar classificados em outras categorias de perseguição (exceto morte e desaparecimento). No final da década de 1990 e mesmo no início da década de 2000, ações penais contra agentes da repressão não passavam de uma aspiração de familiares de mortos e desaparecidos políticos com possibilidades bastante remotas, na medida em que o próprio MPF, como vimos no capítulo 3, até 2011 em geral arquivava as representações com este propósito alegando a anistia "bilateral".

O sentido tradicional da "conciliação nacional" remete a algumas noções de algumas das obras mais influentes do pensamento político e social brasileiro a respeito da formação de nossa sociabilidade. Entre os três principais expoentes da chamada "geração de 1930", que lançou muitas das bases para uma compreensão mais profunda sobre a 
formação política, social e econômica do Brasil, Gilberto Freyre, por exemplo, entendia, em Casa Grande \& Senzala, que a estabilidade social em meio a relações tão assimétricas engendradas fundamentalmente pela escravidão sempre se fiou, no Brasil, na proximidade e na intimidade daquelas relações, que de algum modo suavizavam as assimetrias e as violências da dominação. ${ }^{3}$ Em outras palavras, a particularidade da formação social do país estaria justamente na capacidade da sociedade brasileira de harmonizar o diferente, o desigual e mesmo o antagônico. Na concepção freyreana, o inacabamento do caminho rumo à modernidade no país não seria propriamente negativo, mas constitutivo (e por isso mesmo não propriamente inacabado) de uma identidade particular e positiva.

A plasticidade (que remete à capacidade do português de misturar-se com outras raças) e o sincretismo social (uma aptidão da sociedade brasileira de abrigar grupos culturalmente diferentes) reatualizariam uma visão idílica da colonização portuguesa no Brasil ao descartarem ou ao menos suavizarem os conflitos por meio da ênfase na adaptação, na tolerância recíproca e no concerto das diferenças ou mesmo antagonismos. É neste sentido que, como destaca Benzaquen de Araújo (2005, p. 45), a escravidão para Freyre, apesar de efetivamente ensejar dominação e violência, não seria absolutamente despótica, uma vez embalada pela plasticidade e pelo sincretismo de nossa formação social. Dominação e violência conviveriam com a confraternização familiar, o que é estendido, a partir dos fundamentos patriarcais da sociedade brasileira, a relações sociais mais amplas. Ao fim e ao cabo, o Brasil teria na grande família híbrida e poligâmica, isto é, no patriarcalismo, a base de sua formação social, que seria assim arredia à incorporação das formas e categorias próprias da política (entendida em seu sentido moderno), da publicidade e da justiça. ${ }^{4}$

Gilberto Freyre, apesar de muito criticado por gerações futuras de cientistas sociais, é lido até hoje porque certamente boa parte de sua narrativa e de sua análise sobre a forma como se constituíram as relações sociais no Brasil é verdadeira. Aliás, é provável que nenhum outro autor tenha conseguido caracterizar tão bem a ambiguidade (como docilidade e violência) e o patriarcalismo nos fundamentos da formação social brasileira, o

\footnotetext{
${ }^{3}$ Os argumentos aqui desenvolvidos têm na interpretação de Ricardo Benzaquen de Araújo (2005) sobre a obra de Gilberto Freyre uma importante referência.

${ }^{4}$ Em Sobrados e Mucambos, que daria certa continuidade na narrativa da formação histórica da sociedade brasileira, Gilberto Freyre identificaria um "processo civilizador" e certa desagregação paulatina da antiga estrutura da casa grande e da senzala. Na medida em que, apesar das ambiguidades, a narrativa em Casa Grande \& Senzala adotava um tom um tanto saudosista, em Sobrados e Mucambos Gilberto Freyre imprimiria certo tom de lamento. Seja como for, apesar do declínio do modelo da casa grande, o autor ainda veria sua continuidade nas bases das relações sociais (cf. Freyre, 2006).
} 
que o autor pernambucano talvez tenha conseguido fazer em parte justamente porque ele não os encarava de forma necessariamente negativa.

Mas é justamente aí que estaria um dos pontos centrais onde reside a crítica à sua obra. Em Raízes do Brasil, publicado poucos anos depois de Casa Grande \& Senzala, Sérgio Buarque de Holanda (2006, p. 153) diria justamente que "o Estado não é uma ampliação do círculo familiar". 5 Para o autor paulista, o patriarcalismo era justamente um dos fatores que dificultavam o advento de formas de convivência democrática. Isto porque, entre outras coisas, e conforme elaborações de diferentes vertentes da teoria política contemporânea, a democracia pressupõe uma ordem jurídica impessoal e que garanta a eficácia das normas básicas de convivência, entendidas hoje essencialmente como os direitos humanos básicos. ${ }^{6}$ Nas palavras do próprio Sérgio Buarque (2006, p. 153): "Há nesse fato [a formação do Estado moderno] um triunfo do geral sobre o particular, do intelectual sobre o material, do abstrato sobre o corpóreo, e não uma depuração sucessiva, uma espiritualização de formas mais naturais e rudimentares".7

Algo neste sentido também pode ser extraído da discussão em Sérgio Buarque sobre o "homem cordial". Em carta em resposta a Cassiano Ricardo, o historiador paulista se reportaria à origem etimológica da palavra, que remete a "cárdio", coração. Isto é, o "homem cordial” não é necessariamente benevolente, dócil, urbano ou cortês, mas aquele

\footnotetext{
${ }^{5}$ Sérgio Buarque não dispõe de uma crítica explícita a Gilberto Freyre nesta passagem específica, mesmo porque, como veremos adiante, o autor pernambucano não era o único a ver vantagens no patriarcalismo. De todo modo, acredito que podemos colocá-los neste ponto como partilhando e disputando um mesmo debate basicamente por três motivos: a distância temporal entre a publicação de um e outro livro é de apenas cerca de três anos, o contraponto entre os dois autores na análise acerca do patriarcalismo (ou patrimonialismo, como definiria Sérgio Buarque a indistinção dos limites entre a racionalidade pública e a racionalidade privada) é suficientemente explícito, e ambos são tidos como dois dos mais importantes intérpretes do Brasil, de maneira que a fortuna crítica a respeito das duas obras é levada de forma quase inevitável a considerá-las em comparação em muitos aspectos.

${ }^{6} \mathrm{Na}$ argumentação aqui suscitada sirvo-me também de dois textos de Bolivar Lamounier (1987 e 2006) sobre a obra de Sérgio Buarque.

${ }^{7}$ Importa lembrar neste ponto, em contraste com a interpretação formulada aqui sobre a obra de Sérgio Buarque, uma discussão suscitada por Leopoldo Waizbort (2011) sobre a talvez excessiva valorização dos intérpretes de Raizes do Brasil acerca da defesa da democracia e das formas públicas e impessoais do Estado moderno nesta obra. Waizbort remonta à primeira edição do livro, de 1936, para mostrar que a visão de Sérgio Buarque sobre o patriarcalismo era originalmente muito mais ambígua do que muitos dos intérpretes gostariam de supor. Não cabe fazer aqui uma contestação pormenorizada da crítica de Waizbort tanto porque isso me levaria a abrir um parênteses demasiado grande a esta altura quanto porque ela tem razão até certo ponto. Mesmo nas edições posteriores, algo desta ambiguidade pode ser verificado em algumas passagens de Raizes do brasil, como, por exemplo, quando, em diferentes ocasiões, Sérgio Buarque se refere à cordialidade como sendo uma contribuição de nossa sociedade ao Ocidente. Waizbort diz que boa parte da leitura generosa sobre o papel da democracia em Raízes do Brasil seria tributária do famoso "prefácio" que Antonio Candido escreveu para o livro em 1967 e que, justificadamente em função daqueles tempos, pendia a interpretação para aquele lado. Para os propósitos de minha argumentação, no entanto, parece-me suficiente observar que, se Sérgio Buarque encetou mudanças nas edições posteriores aproximando-as da interpretação de Antonio Candido, isso seria minimamente sinal de que o historiador paulista a entendeu como horizonte para um amadurecimento apropriado e desejável de sua própria obra.
} 
que sobrepõe laços sentimentais e familiares aos requisitos impessoais da ordem pública, e de modo também sentimental, o que, além dos adjetivos acima, pode assumir formas menos elevadas, como a irascibilidade. A cordialidade, neste sentido, não seria necessariamente benevolente, podendo ser elemento tanto de coesão como de desagregação social. Além disso, sendo ela benevolente ou não, na medida em que em qualquer caso estaria ligada ao patriarcalismo e ao favor, era considerada pelo autor como um dos principais aspectos da sociabilidade brasileira que a tornariam arredia ao processo de racionalização burocrática requerido para a institucionalização do Estado de Direito. ${ }^{8} \mathrm{~A}$ cordialidade tende a anular o indivíduo, gerando um obstáculo à atribuição de responsabilidades individuais. Nas palavras de Lamounier (1987, p. 60), Sérgio Buarque

"não pretendia [...] alimentar a clássica cantilena daqueles que recorriam à tese da 'bondade' do povo brasileiro para justificar o Estado Novo. O raciocínio destes é conhecido: não sendo o nosso povo marcado por fortes conflitos de raça ou de classe, o modelo político que melhor lhe corresponde não pode ser o liberal, nem o fascista. [...] Defensor do autoritarismo burocrático, acomodatício, bonachão, à maneira do Estado Novo, Cassiano Ricardo é que iria dar à noção do homem cordial esta formulação primorosamente apologética: 'Uma bondade por temor de Deus, por ausência de atritos econômicos, por mestiçamento conciliador de arestas psicológicas e raciais, por índole herdada do português' [...]."

De todo modo, as considerações a respeito de um pretenso caráter pacífico e conciliador do povo brasileiro ganharam outras formulações em autores do pensamento político e social do país e tomaram o senso comum. Em seu pequeno livro de ensaios Brasil: mito fundador e sociedade autoritária, Marilena Chauí (2006) procura depurar e esclarecer os fundamentos mitológicos (em seu sentido tanto etimológico, como narração de acontecimentos lendários, quanto antropológico, como solução fictícia para tensões sociais) de uma espécie de ethos da sociabilidade brasileira. O senso comum a respeito de nossa sociabilidade e de algumas passagens da história do país, muitas vezes reiterado pela cultura de massas, redundaria num imaginário a respeito do que Chauí chamou de "mito fundador" da sociedade brasileira.

$\mathrm{Na}$ obra mencionada, além de escrever breves ensaios sobre temas como a "questão nacional" da Era Vargas e o verdeamerelismo, a autora também dedica um curto capítulo a dois autores do pensamento político e social que teriam contribuído para reforçar as bases da mitologia de uma sociedade pacífica, ordeira e conciliadora: Afonso

\footnotetext{
${ }^{8}$ Embora Holanda não utilizasse exatamente este termo, trata-se de uma resistência ao caminho da isonomia mediada pela lei.
} 
Celso, em Por que me ufano de meu país, que contou com inúmeras edições e era obra obrigatória tanto nos currículos escolares (pelo menos até a primeira metade do século passado) quanto nas prateleiras da classe média brasileira, e Silvio Romero, que em Caráter nacional e as origens do povo brasileiro considerava que a apatia e o nervosismo próprios do brasileiro seriam compensados pela serenidade contemplativa, pelo lirismo e pelo talento precoce. O livro de Afonso Celso, o Visconde de Ouro Preto, por exemplo, embora muito criticado sobretudo pelo modernismo, constituía referência essencial para obras escolares em matéria de civismo e história pelo menos até meados do século passado (Cf. Chauí, 2006, p. 51).

De volta ao sentido tradicional do discurso da "conciliação nacional", nele desaparecem a crítica aos fundamentos da sociabilidade brasileira que podemos encontrar em Sérgio Buarque ou mesmo a ambiguidade sobre aqueles fundamentos que podemos ler em Gilberto Freyre. Na medida em que a partir da segunda metade da década de 2000 aquele discurso passou a ser contestado de forma mais intensa, processo que chegou a uma primeira investida mais contundente com a ação do Conselho Federal da OAB para derrubar a chamada bilateralidade da anistia, começamos a ver ser desenvolvida o que chamei no capítulo 3 de uma "ideologia secundária" (que elabora melhor seus fundamentos) sobre o discurso da "conciliação nacional".

A maior expressão desta ideologia secundária seriam os votos dos ministros do Supremo Tribunal Federal (STF) que decidiram pela improcedência da ação da OAB na ocasião. A maioria daqueles votos se reportou a uma pertinência quase que sociológica da conciliação como apaziguamento, que a anistia proporcionaria. Apenas para lembrar um deles neste sentido, Cezar Peluso (2010, p. 209) ressaltou a escolha da sociedade brasileira pelo caminho da "concórdia", que apenas uma "sociedade superior, qualificada pela consciência dos mais elevados sentimentos de humanidade" poderia trilhar. Os ministros Eros Grau e Gilmar Mendes procuraram inclusive dar status constitucional à anistia e à conciliação que ela ensejaria, elevando-a a uma dimensão fundadora do novo regime democrático institucionalizado pela Constituição Federal de 1988. Nesta exata medida, a anistia teria uma função essencial de, frente a tempos difíceis em que a sociedade brasileira estivesse talvez perdendo seu caminho, reatualizar sua origem, que seria também seu telos. A conciliação, mais uma vez em seu sentido tradicional, significaria a retomada do caminho (natural ou histórico) da sociedade brasileira sem a necessidade de recurso ao emprego sistemático da violência pelo Estado. 
$\mathrm{Na}$ contramão desta apologia, diria Sérgio Buarque do liberalismo que é "teoria neutra, despida de emotividade". O liberalismo, aliás, estaria "em contraste direto com qualquer forma de convívio [...] baseada nos valores sociais" (Holanda, 2006, p. 204-5).

Especialmente a partir do final dos anos 1990, o direito internacional dos direitos humanos passou a experimentar um contexto significativamente mais favorável para a afirmação de seus horizontes normativos. Desde então, Tribunais internacionais humanitários e de direitos humanos foram criados e, no caso latino-americano, a Corte Interamericana de Direitos Humanos (CrIDH) passou a desempenhar um papel mais próativo e a efetivamente desafiar algumas políticas de países do subcontinente atentatórias aos direitos humanos. Como vimos no capítulo 1, já no final da década de 1980, a partir do caso Velásquez-Rodrigues, a CrIDH passou a decidir acerca da obrigação dos Estados de responsabilizarem os agentes envolvidos em graves violações a direitos humanos e de revelar a verdade sobre o passado de atrocidades. Com o desenvolvimento da legislação internacional a respeito do tema e de sua própria jurisprudência, a CrIDH viria a considerar, no caso Barrios Altos, em 2001, as autoanistias que perdoam graves violações aos direitos humanos como incompatíveis com a Convenção Americana de Direitos Humanos (CADH). Já em 2006, no caso Almonacid Arellano, como também vimos no capítulo 1, a Corte passaria a considerar qualquer tipo de anistia que perdoa graves violações como incompatíveis com a CADH.

Acompanhando este movimento do cenário internacional, as demandas pela implementação dos horizontes normativos da justiça de transição ganharam muito em politização também no Brasil, extrapolando o círculo restrito da luta encampada por décadas pelos familiares. Sobretudo a partir de 2007, a atuação da CEMDP, por meio de suas publicações, e especialmente a Comissão de Anistia, por meio de suas publicações, campanhas de memória em todo o Brasil e formação de quadros atentos aos desenvolvimentos mais recentes da justiça de transição em nível internacional, passaram a desempenhar um papel central neste cenário. De lá para cá, como também vimos no capítulo 2, as comissões de reparação assumiram a tarefa de, além de conceder indenizações, redimir algumas narrativas antes silenciadas ou que sofriam uma série de estigmatizações, de modo que, sobretudo a Comissão de Anistia, passou a ser o carrochefe da preservação oficiosa da memória sobre a repressão do regime militar, pelo menos até a criação da Comissão da Verdade. A despeito de alguns atritos que são próprios da natureza das comissões de reparação enquanto instâncias de interlocução entre Estado e sociedade civil, estas políticas públicas de memória e verdade certamente realçaram as 
lutas promovidas por perseguidos e familiares de mortos e desaparecidos políticos há décadas e foram imprescindíveis para colocar a questão de uma memória crítica do período militar na agenda de debates em nível nacional.

Meses depois do julgamento de 2010 do STF sobre a constitucionalidade da bilateralidade da anistia, seguindo a tendência de sua jurisprudência, a $\mathrm{CrIDH}$ condenaria o Brasil no caso Guerrilha do Araguaia a, entre outras coisas, julgar e condenar agentes do Estado envolvidos com graves violações e a criar uma comissão da verdade. Desde então cresceria muito, no Brasil, o número de grupos e entidades da sociedade civil empenhados no tema da "memória, verdade e justiça". Associados com outras organizações de esquerda e com comissões de familiares de mortos e desaparecidos políticos, estes grupos têm promovido, sobretudo a partir de 2010, uma série de manifestações e atos públicos em defesa da responsabilização de pessoas envolvidas com o autoritarismo e com graves violações a direitos humanos no país. Em conjunto com a pressão da comunidade internacional representada pela sentença da Corte Interamericana e pelo desenvolvimento da agenda dentro do Estado brasileiro por meio da CEMDP e da Comissão de Anistia, a atuação destes grupos foi essencial também para constranger o governo brasileiro a acelerar o processo de criação de uma comissão da verdade. Além disso, depois da sentença da CrIDH no caso Guerrilha do Araguaia, o MPF mudou sua antiga postura de arquivamento de representações sobre crimes cometidos por agentes do Estado durante a ditadura e começou a mover ações para a tentativa de julgamento e condenação destes agentes.

É nestes termos que o percurso desta tese procurou demonstrar também que o sentido tradicional da "conciliação nacional" associada ao processo justransicional brasileiro passou a ter sua hegemonia contestada de forma significativa. Algumas das demandas de entidades da sociedade civil que até pouco tempo atrás não eram consideradas como negociáveis passaram a ser atendidas, como a identificação dos agentes da repressão responsáveis pelas graves violações.

Conforme foi discutido no capítulo 4, a CNV foi capaz de levar o tema da memória, verdade e justiça ao topo da agenda do debate público desde sua instalação e sobretudo no curso de seu último ano de funcionamento, em 2014. A ampla divulgação de seus trabalhos contribuíram, por exemplo, para que vários Estados, municípios e entidades da sociedade civil criassem suas próprias comissões da verdade. Neste processo, as diferentes comissões puderam, apesar de alguns atritos, trocar informações, documentos, experiências e suporte técnico. Isto também permitiu, como vimos, que a agenda da 
memória, verdade e justiça ganhasse maior capilaridade num país de dimensões continentais como o Brasil.

Outra contribuição importante de seus trabalhos se relaciona com as dimensões coletiva e individual que a Comissão procurou atender em relação ao chamado direito à verdade. Do ponto de vista coletivo, a CNV descreveu minuciosamente a estrutura da repressão, no volume 1 de seu relatório final e, no volume 2 , deu conta de relatos sobre violações que atingiram diferentes segmentos sociais. Com relação à dimensão individual do direito, especialmente o volume 3 do relatório final apresentou um esclarecimento circunstanciado dos casos de violações aos direitos humanos praticadas contra mortos e desaparecidos políticos.

A conciliação entre vítimas e agressores não precisa ser, necessariamente, um horizonte normativo da justiça de transição. Pelo menos não quando sua realização se colocar como mutuamente excludente em relação à justiça e à responsabilização. A justiça não está no registro do sentido tradicional de conciliação; ela diz respeito à correção de um dano ou à distribuição de determinados bens ou sanções conforme o mérito, no primeiro caso, ou o demérito, no segundo, quando ela assume em geral um aspecto litigioso. $\mathrm{Na}$ justiça, geralmente, as partes não chegam e nem precisam chegar a termo com um litígio em função de um acordo, de uma negociação, mas mediante a aplicação de mandamentos e sentenças, considerados justos de um ponto de vista normativo, ainda que uma das partes (ou mesmo ambas) saia insatisfeita do processo. Neste sentido, de fato, como operar justiça e conciliação ao mesmo tempo? Se a justiça depender de que violadores e vítimas se reconciliem, muitas vezes ela não poderá ser aplicada. Talvez um termo mais apropriado para a finalidade de um mínimo de coesão social numa democracia seja "tolerância", termo que aceita e até mesmo pressupõe o dissenso, diferentemente dos usos mais comuns de "conciliação".

Como vimos no capítulo 1, Pablo de Greiff (2010 e 2012) é um dos autores que assumiu uma tarefa de redefinir os contornos que poderia assumir a categoria de conciliação de um ponto de vista normativamente positivo na justiça de transição. A reconciliação, em seu entendimento, não se refere necessariamente a um acerto entre violador e vítima, mas a um reconhecimento da sociedade via política estatal dos sofrimentos sofridos no passado, tornando-os comunicáveis. De Greiff conecta ressentimento com não-reconhecimento e, inversamente, reconciliação com reconhecimento. Para ele, o ressentimento decorre justamente da falta de reconhecimento do sofrimento e das violações infligidas, o que impede que um indivíduo ou grupo se sinta 
parte de uma mesma sociedade, composta também por pessoas que, em sua maioria, não sofreram as mesmas violações.

A superação daquela noção tradicional em que a conciliação (re)atualizaria as origens da formação da sociedade brasileira em torno de um apaziguamento de sentimentos opostos pautado no esquecimento tem levado a uma aproximação do autoentendimento da relação entre Estado e sociedade no país a uma visão liberal, em que a impessoalidade, a ordem pública, os direitos do indivíduo frente ao Estado e suas responsabilidades são colocados em primeiro plano.

É neste sentido que, talvez mais do que em outros campos de políticas públicas e da jurisprudência, é possível identificar nos desenvolvimentos da justiça de transição como Estado e sociedade configuram este processo contínuo de auto-entendimento de seus objetivos e de seus próprios fundamentos políticos. De uma visão em que conciliação e autoritarismo podiam conviver bem com uma certa característica (como vimos, bastante disputada e problemática) de nossa formação social, caminhamos para um entendimento segundo o qual os fundamentos impessoais do Estado de Direito, formas de justiça restaurativa e retributiva e as luzes lançadas sobre o passado sob o signo da "verdade" ganham primazia. O desenvolvimento da justiça de transição no Brasil, assim, daria sinais claros de passos no sentido do "longo caminho" brasileiro rumo ao "Ocidente".

A justiça de transição assume uma tarefa de deslegitimação (simbólica e funcional) do regime anterior e redefine o que significa injustiça na atuação do Estado. Ela tem a função de catalisar a identidade social em torno de um novo paradigma normativo no qual a rule of law passa a ter primazia. É por estes motivos que, como foi discutido no capítulo 1, a justiça de transição promove uma certa hipertrofia do direito em seu âmbito. Trata-se de uma teoria em que reparações econômicas, revelação da verdade, preservação da memória e responsabilização criminal, civil e administrativa de violadores dos direitos humanos são todas medidas tidas como necessárias para um processo de acerto de contas, o que é consideravelmente mais abrangente do que teorias da responsabilidade e da responsabilização na Justiça Comum. Isto só pode ser explicado pela dimensão simbólica da justiça de transição, associada que está com uma representação fundacional de um novo regime e com a ruptura em relação ao autoritarismo e à violência institucional do passado.

Neste sentido, não basta a derrota política do regime anterior, mas é preciso alcançar seu descrédito social. Se, para Thomas Payne (1974, p. 129), a questão sobre levar o rei Luís XVI a julgamento era uma oportunidade de se estabelecer uma verdade sobre a monarquia (absoluta), a justiça de transição contemporaneamente, nos casos em 
que se segue a regimes autoritários, tem a função de estabelecer uma verdade sobre a ditadura.

Conforme discutido ao final do último capítulo, este propósito pode estar relacionado em parte com o dimensionamento do papel do Estado em uma época em que, desde um ponto de vista internacional e pelo menos em termos de teoria política, o liberalismo assume contornos de hegemonia. Ainda mais quando veiculada por órgãos do Estado e (como no caso brasileiro) ligada ao governo, a "verdade" neste contexto já não pode remeter a uma pretensão de totalidade. Em outras palavras, o saldo "positivo" ou "construtivo" da efetivação de todos os mecanismos da justiça de transição tem um sentido essencialmente negativo: o dever de não-repetição. Isto é, positivamente, trata-se de lições ao Estado sobre que caminhos evitar e o que seria preciso preservar para impedir que as atrocidades do passado aconteçam novamente.

Outro indício deste movimento pode ser identificado, por exemplo, no relatório final da Comissão da Verdade, no qual, como vimos no capítulo 4, mesmo quando a atuação da luta armada é colocada em foco, ela o é por uma via fundamentalmente individual, isto é, por meio das biografias de mortos e desaparecidos políticos. ${ }^{9}$ É o indivíduo que está em foco e que tem sua vida redimida, não as visões de mundo e os projetos de que partilhavam. Ironicamente ou não, é justamente por via desta dimensão essencialmente individual que os integrantes da luta armada são redimidos, eles que, em grande parte, partilhavam de um sentimento comunitário talvez difícil para as novas gerações entenderem hoje e que os levava a eventualmente renunciar à vida privada por uma causa social. Apesar das diferenças que os fragmentavam em inúmeras dissidências, os membros da luta armada partilhavam de um entendimento segundo o qual a vida presente de um indivíduo não teria plenitude enquanto injustiças sociais e políticas pudessem ser perpetuadas. Hoje estes mesmos sujeitos são redimidos pelas comissões de reparação cada um à sua proporção (em boa parte segundo critérios laborais) e pelas comissões da verdade também em função da dimensão sobretudo individual de sua "coragem" e "desprendimento" em lutar pelo que acreditavam.

Estas considerações críticas dizem menos respeito ao que a Comissão da Verdade poderia ter feito de diferente, e estão mais relacionadas com um trazer à tona de um contexto geopolítico e cultural em que seus trabalhos (e a própria justiça de transição em geral) se inserem. Elas dizem respeito a limites espirituais de sua atividade, os quais, por

\footnotetext{
${ }^{9}$ Isto se levarmos em conta que a CNV dedicou todo um volume às biografias dos mortos e desaparecidos, mas dedicou apenas um capítulo, no volume 2 , à resistência da sociedade civil às violações estatais.
} 
sua vez, são determinados em grande medida por condições materiais de produção da vida (pós-)moderna em um registro muito mais abrangente do que o referente a questões sobre, por exemplo, os poderes judiciais ou extra-judiciais da Comissão, seu número e qualidade de membros e de outros integrantes, sua vinculação à Casa Civil da Presidência da República etc.

A justiça de transição está historicamente ligada a uma expiação de males do Estado contra o indivíduo. Como vimos no capítulo 1, ela teve seus primórdios cultivados a partir de revisões judiciais e de políticas públicas que em alguma medida tentavam lidar com um passado não apenas de autoritarismo, mas de totalitarismo (fosse o nazi-fascista ou o soviético), que é caracterizado justamente por uma dominação completa do Estado sobre a sociedade. Ainda que muitos capitalistas também tenham se beneficiado do desenvolvimento do nazi-fascismo, este era caracterizado essencialmente por tamanha hipertrofia da esfera pública ${ }^{10}$ que restaria apenas espaço para o diálogo do sujeito consigo mesmo. As experiências totalitárias chamaram a atenção para os riscos do hiperdimensionamento dos poderes do Estado não apenas em matéria de justiça de transição, mas em praticamente todas as esferas de racionalidade da vida moderna, da economia à política, passando pela arte.

Contudo, a aprendizagem a respeito destes riscos e do desempenho essencialmente "estatal" do mal ou das violações de direitos foi em grande parte transportado para as elaborações da justiça de transição em contextos também de autoritarismo não totalitário ou guerras civis. Em outras palavras, não há uma justiça de transição ou um corpo de políticas públicas, de legislação internacional ou jurisprudência análogos em termos de densidade e coesão para outras modalidades de catástrofes humanitárias, como as provocadas até hoje em muitos países e setores da economia em função da exploração da mão de obra, em muitos casos até mesmo em condições de semi ou total escravidão. Não é por outro motivo que, por exemplo, no Brasil, apesar de alguns esforços da Comissão de Anistia (como vimos no capítulo 2) e da Comissão da Verdade (como vimos no capítulo 4) de dar conta de conflitos que ocorreram no campo durante o período militar, terem os trabalhadores rurais sido mais uma vez relativamente negligenciados. Veja-se, por exemplo, o nível de atenção que deram as comissões de reparação, a Comissão da Verdade e a mídia sobre o caso do ex-deputado Rubens Paiva, assassinado sob os auspícios do Estado, em comparação com a atenção dada aos inúmeros casos de indígenas

\footnotetext{
${ }^{10}$ Em que, segundo Hannah Arendt (2011), tudo, até mesmo a vida privada e a intimidade, é colocado sob o holofote do Estado.
} 
e camponeses mortos ou desaparecidos, seja durante o período militar, antes ou depois.

Em sua maioria, as mortes no campo estão relacionadas à estrutura fundiária e de distribuição desigual da terra, mas por contarem com possibilidades menores de documentação e por estarem relacionadas a execuções "privadas" (por jagunços a mando de fazendeiros), recebem incomparavelmente menos atenção. Em parte, isto ocorre provavelmente pela menor valorização que sempre experimentou o trabalhador rural em relação ao trabalhador urbano, profissional liberal ou capitalista; em outra parte, talvez também porque estas mortes e execuções apenas muito obliquamente têm a ver com o mal exercido pelo Estado, isto é, fundamentalmente pela via de sua "negligência" ou "conivência", mas raramente em função da atuação direta de seus agentes (uma das exceções neste sentido foi a morte de camponeses a propósito da repressão à Guerrilha do Araguaia).

Ainda que o poder privado por vezes fosse associado ao poder público na ditadura, ele é avaliado criticamente fundamentalmente na medida em que se imiscuiu com o poder público a propósito do exercício da repressão. Não há um debate sobre a opressão puramente privada, por exemplo, do capital sobre o trabalho. Isto não significa que ela não exista, mas diz muito dos limites que o Estado reconhece para si como passíveis de sua avaliação crítica.

Sobre as violações cometidas contra as populações indígenas, por exemplo, Sônia Guajajara, da coordenação da Articulação dos Povos Indígenas do Brasil, chamou atenção para a importância da instalação de uma Comissão da Verdade Indígena no país, pois, na opinião da representante, as recomendações atinentes aos povos indígenas estão diluídas no relatório final da Comissão Nacional da Verdade. Apesar da expansão no reconhecimento de mortos e desaparecidos por atuação estatal também contra pessoas não classificadas como militantes políticos no relatório final da CNV, Guajajara considerou a expansão insuficiente. Em suas palavras:

"Acaba que a CNV não está considerando os povos indígenas no relatório porque diz que não lutaram contra a ditadura. Nós queremos que reconheçam também toda a violação e o genocídio sofrido no período da ditadura porque foi uma violência cometida nesse período. Foi exatamente neste período que houve o maior roubo de terras indígenas no Brasil, o que intensificou o conflito pela demarcação de terras". 11

\footnotetext{
${ }^{11}$ Veja a declaração em WALTZ, I. "Congresso Nacional e movimentos sociais debatem relatório final da CNV”. Associação Brasileira de Imprensa. Rio de Janeiro, 12 dez. 2014. Notícias. Disponível em: http://www.abi.org.br/congresso-nacional-e-movimentos-sociais-debatem-relatorio-final-da-cnv/. Último acesso em 21 de abril de 2015.
} 
Se um dos fundamentos do liberalismo é justamente proteger o indivíduo do Estado, é para a consecução deste desígnio que as comissões da verdade e todo o aparato justransicional são montados: seja do ponto de vista retrospectivo, em que o reconhecimento da responsabilidade estatal e a responsabilização individual de violadores ganham uma dimensão de justiça retributiva, ou em que a valorização das dores dos que sofreram suplícios sob os auspícios de agentes do Estado ganha uma dimensão de justiça restaurativa; ou seja do ponto de vista prospectivo, em termos de não-repetição. Por outro lado, outras formas de injustiça também ligadas ao que se poderia nomear de "capitalismo periférico" não são objeto de revisões e elaborações normativas em torno de uma totalidade teórica como a justiça de transição, ainda que sejam injustiças que, sobretudo nas relações entre capital e trabalho no campo e entre proprietários de terras e indígenas no Brasil, tenham produzido por décadas não apenas redução significativa da qualidade e da expectativa de vida de camponeses e indígenas, mas inclusive condições de escravidão ou semi-escravidão, torturas, mortes e desaparecimentos.

Em alguma medida, ainda que pela via do reformismo e não propriamente por uma ruptura revolucionária e/ou socialista, no início dos anos 1960, a discussão em torno das reformas de base, com suas propostas mais radicais sobre reforma agrária, por exemplo, estava justamente a desafiar aquelas relações. Ironicamente, talvez, o golpe militar e a ditadura que se instaurou a partir de então (e que são objeto de avaliação crítica de nossa justiça de transição hoje) deram-se em grande parte justamente para interromper (ou melhor, aniquilar) aquele processo. Se hoje já não é mais possível recuperar aquele ambiente de discussões acerca das estruturas de dominação no capitalismo periférico, isso se deve em parte aos mais de 20 anos de ditadura civil-militar e em outra parte ao novo contexto geopolítico em que nos inserimos pelo menos desde os anos 1990 para cá. A justiça de transição, um campo abertamente liberal com um exercício ex-post facto de avaliação do passado, não possui a vantagem de redimir alternativas contrafactuais e eventualmente emancipatórias que se colocaram em algum momento em relação ao autoritarismo que acabou por se impor, mas de afirmar um novo futuro do passado, que lança um desígnio que pode ser fundamentalmente condensado na ideia de que o Estado não pode atacar, mas, pelo contrário, precisa proteger o indivíduo.

Neste sentido, os próprios avanços na justiça de transição no Brasil dizem muito sobre um auto-entedimento do Estado e da política no país. O fato de este autoentendimento poder soar quase que naturalizado para muitos hoje talvez seja ainda mais 
um indício dos contornos de hegemonia de que ele tem se revestido há algumas décadas no pano internacional. 


\section{BIBLIOGRAFIA}

\section{LITERATURA}

ABRÃO et al. 2009. Justiça de transição no Brasil: o papel da Comissão de Anistia do Ministério da Justiça. In: Revista Anistia Política e Justiça de Transição, n. 1.

ABRÃO, Paulo \& GENRO, Tarso. 2012. Os direitos de transição e a democracia no Brasil: estudos sobre Justiça de Transição e teoria da democracia. Belo Horizonte: Fórum.

ABRÃO, Paulo \& TORELLY, Marcelo. 2010. Justiça de Transição no Brasil: a dimensão da reparação. In: SANTOS, Boaventura et al. (orgs.). Repressão e memória política no contexto ibero-brasileiro: Estudos sobre Brasil, Guatemala, Moçambique, Peru e Portugal. Brasília: Ministério da Justiça, Comissão de Anistia; Portugal: Universidade de Coimbra, Centro de Estudos Sociais. 2011. O programa de reparações como eixo estruturante da Justiça de Transição no Brasil. In: REATEGUI, Felix (org.). Justiça de Transição: manual para a América Latina. Brasília: Ministério da Justiça; New York: International Center for Transitional Justice.

. 2012. Resistance to Change: Brazil's persistente amnesty and its alternatives for truth and justice. In: PAYNE, Leigh \& LESSA, Francesca (eds.). Amnesty in the Age of Human Rights Accountability: international and comparative perspectives. Cambridge: Cambridge University Press.

ACOSTA, Mariclaire \& ENNELIN, Esa. 2006. The 'Mexican Solution' to Transitional Justice. In: ROHT-ARRIAZA, Naomi \& MARIEZCURRENA, Javier (eds.). Transitional Justice in the twenty-first century: beyond truth versus justice. Cambridge USA Press.

ALMEIDA. F. P. L. de. 2008. Os princípios constitucionais entre deontologia e axiologia: pressupostos para uma teoria hermenêutica democrática. In: Revista Direito GV, vol. 4 , n. 2 [online].

ANDERSON, Perry. 1994. O fim da história: de Hegel a Fukuyama. Rio de Janeiro: Jorge Zahar. 
ARANTES, Rogério B. \& COUTO, Cláudio G. 2009. Uma Constituição incomum. In: CARVAlhO, M. A. R.; ARAÚJO, C.; \& SIMÕES, J. A. (orgs.). A Constituição de 1988: passado e futuro. São Paulo: Hucitec/Anpocs.

ARANTES, Rogério B. 2005. Constitutionalism, the expansion of Justice and the Judicialization of Politics in Brazil. In: SIEDER, Rachel; SCHJOLDEN, Line; ANGELL, Alan. The Judicialization of Politics in Latin America. New York: Palgrave Macmillan.

ARAÚJO, Cícero. 2003. Apresentação. In: POCOCK, J. G. A. Linguagens do ideário político. São Paulo: EDUSP.

ARAÚJO, Ricardo Benzaquen de. 2005. Guerra e Paz: Casa Grande \& Senzala e a obra de Gilberto Freyre nos anos 30. São Paulo: Ed. 34.

ARENDT, Hannah. 1965. Eichmann in Jerusalem. New York: Viking Press. . 2004. Responsabilidade pessoal sob ditadura. In: Responsabilidade $e$ julgamento. São Paulo: Companhia das Letras. . 2008. A condição humana. São Paulo: Forense Universitária e EDUSP. 2011. Origens do totalitarismo. São Paulo: Companhia das Letras.

ASMAL, K.; ASMAL, L.; ROBERTS, R. S. (eds.). 1997. Reconciliation through Truth: a Rekoning of Apartheid's Criminal Governance. New York: St. Martin's.

BALL, Terence. 2004. Aonde vai a teoria política? In: Revista Sociologia e Política, Curitiba, n. 23, nov. de 2004.

BANDEIRA, L. A. M. 2001. O governo João Goulart: as lutas sociais no Brasil (19611964). Rio de Janeiro: Revan; Brasília: EdUnB.

BASCH, F. F. 2007. The doctrine of the Inter-American Court of Human Rights regarding State's duty to punish human rights violations and its dangers. In: American University International Law Review, v. 23, n.1.

BASTOS, Élide Rugai. 1984. As Ligas Camponesas. Petrópolis: Vozes. . 2002. Pensamento social e Escola Sociológica Paulista. In: MICELI, Sérgio (org.). O que ler na Ciência Social brasileira (1970-2002). São Paulo: Sumaré.

BASTOS, Lucia E. A. F. 2009. A anistia brasileira em comparação com as da América Latina: uma análise perspectiva do direito internacional. In: SANTOS, Cecília McDowell; TELES, Edson; TELES, Janaína de Almeida (orgs.). Desarquivando a ditadura: memória e justiça no Brasil, Vol. II. São Paulo: Hucitec.

BECCARIA, Cesare. 1995 [1769]. On Crimes and Punishments and Other Writings. Cambridge: Cambridge University Press. 
BINDER, C. 2011. The prohibition of amnesties by the Inter-American Court of Human Rights. In: Germal Law Journal, v.12, n.5.

BODIN, Jean. 1992. On Sovereignty: Four Chapters from "The Six Books of the Commonwealth". Cambridge; New York: Cambridge University Press.

BRANDÃO, Gildo Marçal. 2010a. Ideias e argumentos para o estudo das ideias políticas no Brasil. In: COELHO, Simone de Castro Tavares (org.). Gildo Marçal Brandão: itinerários intelectuais. São Paulo: Hucitec / Fapesp. . 2010b. Linhagens do pensamento político brasileiro. São Paulo: Hucitec.

CARVALHO, José Murilo de. 2009. A formação das almas: o imaginário da República no Brasil. São Paulo: Companhia das Letras.

CASTRO, R. S. 2014. A dimensão da "justiça" na Justiça de Transição: uma aproximação com o caso brasileiro. In: MEYER, E. P. N. \& CATTONI de OLIVEIRA, M. A. (orgs.). Justiça de Transição nos 25 anos da Constituição de 1988. Belo Horizonte: Initia Via.

CATTONI de OLIVEIRA, M. A \& MEYER, E. P. N. (orgs.). 2014. Justiça de Transição nos 25 anos da Constituição de 1988. Belo Horizonte: Initia Via.

CATTONI de OLIVEIRA, M. A. \& GOMES, D. F. L. 2014. A história, a memória, os soberanos: a justiça de transição e o projeto Constituinte do Estado democrático de Direito. In: PIOVESAN, Flávia \& PRADO, Inês V. S. (orgs.) Direitos Humanos atual. Rio de Janeiro: Elsevier.

CATTONI de OLIVEIRA, M. A. 2010. Democracia sem espera e processo de constitucionalização: uma crítica aos discursos oficiais sobre a chamada "transição política brasileira". In: Revista Anistia Política e Justiça de Transição, n. 3. Brasília: Ministério da Justiça.

CHAUÍ, Marilena. 2006. Brasil: mito fundador e sociedade autoritária. São Paulo: Fundação Perseu Abramo.

CHRISTOFOLETTI, Rogério. 2000. O discurso da transição: mudança, ruptura e permanência. Itajaí: Ed. Univali.

CÍCERO, Marco Túlio. 2013. De República, livro II. In: BERNARDO, I. O De Republica de Cícero: natureza, politica e história. Dissertação de Mestrado, Faculdade de Filosofia Letras e Ciências Humanas. São Paulo: USP.

CLARK, Roger S. 1990. Crimes against Humanity at Nuremberg. In: GINSBERGS, G. \& KUDRIAVTSEV, V. N. (eds.). The Nuremberg Trial and International Law. Norwel, Mass.: Kluwer Academic Publishers. 
COUTINHO, Carlos Nelson. 1984. A democracia como valor universal e outros ensaios. Rio de Janeiro: Salamandra.

CRAIG, Paul P. 1997. Formal and Substantive Conceptions of the Rule of Law: an Analytical Framework. In: Public Law: 467.

CUEVA, Eduardo Gonzáles. 2006. The Peruvian Truth and Reconciliation Commission and the challenge of impunity. In: ROHT-ARRIAZA, Naomi \& MARIEZCURRENA, Javier (eds.). Transitional Justice in the twenty-first century: beyond truth versus justice. Cambridge USA Press.

. Sem data. Perspectivas teóricas sobre la justicia transicional. Disponível em: $<$ http://imas2010.files.wordpress.com/2010/07/gonzalez_cueva.pdf $>$. Último acesso em: 29 de out. 2014.

CUNHA, Paulo Ribeiro da. 2010. Militares e anistia no Brasil: um dueto desarmônico. In: SAFATLE, Vladimir \& TELES, Edson (orgs.). O que resta da ditadura: a exceção brasileira. São Paulo: Boitempo.

DAHL, Robert. A. 1989. Democracy and its critics. New Haven and London: Yale University Press.

DALY, Erin. 2008. Truth Skepticism: an Inquiry into the Value of Truth in Times of Transition. In: International Journal of Transitional Justice, 2 (2008).

DEBRUN, Michel. 1983. A “conciliação” e outras estratégias. São Paulo: Brasiliense.

DIMOULIS, D. 2010. Justiça de transição e função anistiante no Brasil: Hipostasiações indevidas e caminhos de responsabilização. In: .; SWENSSON JUNIOR, L.

J.; MARTINS, A.. (orgs.) Justiça de Transição no Brasil: Direito, responsabilização e verdade. São Paulo: Saraiva, Direito GV.

DIMOULIS, D.; SWENSSON JUNIOR, L. J.; MARTINS, A. (orgs.). 2010. Justiça de Transição no Brasil: Direito, responsabilização e verdade. São Paulo: Saraiva, Direito GV.

DREIFUSS, René A. 1981. 1964: a conquista do Estado. Ação política, poder e golpe de classe. Petrópolis: Vozes.

DU TOIT, André. 2000. The moral foundations of the South African TRC: Truth as Acknowledgement and Justice as Recognition. In: ROTBERG, Robert and THOMPSON, Dennis (eds.). Truth v. Justice: the morality of Truth Commissions. Ed. Robert Rotberg and Dennis Thompson. Princeton: Princeton University Press.

DUFF, R. A.; FARMER, Lindsay; MARSHALL, Sandra; and TADROS, Victor. 2007. The Trial on Trial. Vol. 3. Oxford; Portland: Hart Publishing. 
ELSTER, Jon \& SLAGSTAD, Rune. 2003. Introducción. In: ELSTER, Jon \& SLAGSTAD, Rune (eds.). Constitucionalismo y Democracia. México: Fondo de Cultura Económica.

ELSTER, Jon. 1989. Marxismo, funcionalismo e teoria dos jogos: argumentos em favor do individualismo metodológico. In: Lua Nova, n. 17, junho de 1989. . 2004. Closing the books: transitional justice in historical perspective. New York: Cambridge University.

FERNANDES, Florestan. 2006. A Revolução Burguesa no Brasil: ensaio de interpretação sociológica. São Paulo: Globo.

FIGUEIREDO, Argelina C. \& LIMONGI, Fernando. 1999. Executivo e Legislativo na nova ordem constitucional. Rio de Janeiro: Editora FGV.

FIGUEIREDO, Argelina C. 1993. Democracia ou Reformas? Alternativas democráticas à crise política: 1961-1964. Rio de Janeiro: Paz e Terra.

FINKELKRAUT, Alain. 1992. Remembering in Vain: the Klaus Barbie Trial and Crimes Against Humanity. New York: Columbia University Press.

FORST, Rainer. 2011. The Right to Justification: Elements of a Constructivist Theory of Justice. New York: Columbia University Press.

FREEMAN, Mark. 2009. Necessary Evils: Amnesties and the Search for Justice. New York: Cambridge University Press.

FREYRE, Gilberto. 1978. Casa Grande \& Senzala: formação da família brasileira sob o regime da economia patriarcal. Rio de Janeiro: Jose Olympio. . 2006. Sobrados e Mucambos: decadência do patriarcado rural e desenvolvimento do urbano. São Paulo: Global.

FUKUYAMA, Francis. 1992. Fim da história e o último homem. Rio de Janeiro: Rocco.

FULLER, Lon L. 1958. Positivism and Fidelity to Law - a Reply to Professor Hart. IN: Harvard Law Review, 71.

GADAMER, H. G. 1989. Truth and Method. New York: Crossroad.

GINSBURG, Tom. 2003. Judicial Review in new Democracies: Constitutional Courts in Asian cases. Cambridge: Cambridge University Press.

GOMES, Luiz Flávio \& MAZZUOLI, Valério de Oliveira. 2011. Crimes da ditadura militar e o Caso Araguaia: aplicação do direito internacional dos direitos humanos pelos juízes e tribunais brasileiros. In. GOMES, Luiz Flavio; MAZZUOLI, Valério de Oliveira (coords.). Crimes da ditadura militar: uma análise à luz da 
jurisprudência atual da Corte Interamericana de Direitos Humanos. São Paulo: Revista dos Tribunais.

. 2014. Crimes da ditadura e a aplicação do direito internacional dos direitos humanos pelos juízes e Tribunais brasileiros. In: PIOVESAN, Flávia \& PRADO, Inês V. S. (orgs.) Direitos Humanos atual. Rio de Janeiro: Elsevier.

GORENDER, Jacob. 1987. Combate nas trevas. A esquerda brasileira: das ilusões perdidas à luta armada. São Paulo: Ática.

GRAMSCI, Antonio. 2006. Cadernos do Cárcere, vol. 2. Rio de Janeiro: Civilização Brasileira.

GRECO, Heloisa Amélia. 2003. Dimensões fundacionais da luta pela anistia. Tese de Doutorado. Belo Horizonte: Departamento de História-UFMG.

. 2009. Anistia anamnese vs. Anistia amnésia: a dimensão trágica da luta pela anistia. In: SANTOS, Cecília McDowell; TELES, Edson; TELES, Janaína de Almeida (orgs.). Desarquivando a ditadura: memória e justiça no Brasil, Vol. II. São Paulo: Hucitec.

GREIFF, Pablo de. 2010. Justiça e Reparações. In: Revista Anistia Politica e Justiça de Transição, n. 3. Brasília: Ministério da Justiça.

. 2012. Theorizing Transitional Justice. In: WILLIAMS, Melissa S.; NAGY, Rosemary; ELSTER, Jon (eds.). Transitional Justice. New York and London: New York University Press.

GROOME, Dermot. 2011. The right to truth in the fight against impunity. In: Berkley Journal of International Law, 29 (1).

HABERMAS, Jürgen. 2003a. A soberania do povo como processo. In: HABERMAS, Jürgen. Direito e democracia: entre facticidade e validade, vol. II. Rio de Janeiro: Tempo Brasileiro.

. 2003b. Direito e democracia: entre facticidade e validade, vol. I. Rio de Janeiro: Tempo Brasileiro.

. 2003c. O Estado democrático de Direito: uma amarração paradoxal de princípios contraditórios? In: HABERMAS, Jürgen. Era das transições. Rio de Janeiro: Tempo Brasileiro.

. 2004. Sobre a coesão interna entre Estado de direito e democracia. In: HABERMAS, Jürgen. A inclusão do outro: estudos de teoria política. São Paulo: Edições Loyola. 
HAFNER, Donald L. \& KING, Elizabeth B. L. 2007. Beyond traditional notions of Transitional Justice: how Trials, Truth Commissions, and other tools for accountability can and should work together. In: Boston College International and Comparative Law Review, vol. 30, issue 1.

HAMILTON, Alexander et. al. 1984. O Federalista. Brasília: Ed. Universidade de Brasília.

HAMPTON, Jean. 1995. Democracy and the Rule of Law. In: SHAPIRO, I (ed.). Nomos XXXVI: the Rule of Law. New York: New York University Press.

HANASHIRO, O. 2001. O sistema interamericano de proteção aos direitos humanos. São Paulo: Edusp.

HART, H. L. A. 1958. Positivism and the Separation of Law and Morals. In: Harvard Law Review, 71.

HAYNER, Priscilla B. 2011. Unspeakable truths: facing the challenges of Truth Commissions. New York: Routledge.

HIPÓLITO, Lúcia. 1985. De raposas e reformistas: o PSD e a experiência democrática brasileira (1945-64). Rio de Janeiro: Paz e Terra.

HOBBES, Thomas. 1988. Leviatã ou matéria, forma e poder de um Estado eclesiástico e civil. São Paulo: Nova Cultural.

HOLANDA, Sérgio Buarque de. 2006. Raízes do Brasil. In: ARAÚJO, Ricardo Benzaquen de \& SCHWARCZ, Lilia Moritz (orgs.). Raízes do Brasil: edição comemorativa 70 anos. São Paulo: Companhia das Letras.

HONNETH, Axel. 1995. The Struggle for Recognition: The Moral Grammar of Social Conflicts. Cambridge: MIT Press.

HUNTINGTON, Samuel P. 1991. The third Wave: democratization in the late twentieth century. University of Oklahoma Press.

JASMIN, Marcelo \& FERES JÚNIOR, João. 2006. História dos conceitos: dois momentos de um encontro intelectual. In: JASMIN, Marcelo G.; FERES JÚNIOR, João (orgs.). História dos conceitos: debates e perspectivas. Rio de Janeiro: Ed. PUC-Rio / Edições Loyola / IUPERJ.

JASMIN, Marcelo. 2007. Lenguajes políticos en el mundo de la acción: historia conceptual y teoria política. In: Prismas, Revista de história intelectual, n. 11.

KIRCHHEIMER, Otto. 1961. Political Justice: the Use of Legal Procedure for Political Ends. Westport, Connecticut: Greenwood Press. 
KOSELLECK, Reinhart. 2006a. Uma resposta aos comentários sobre o Geschichtliche Grundbegriffe. In: JASMIN, Marcelo G.; FERES JÚNIOR, João (orgs.). História dos conceitos: debates e perspectivas. Rio de Janeiro: Ed. PUC-Rio / Edições Loyola / IUPERJ.

. 2006b. Futuro passado: uma contribuição à semântica dos tempos históricos. Rio de Janeiro: Contraponto, PUC-Rio.

KRAPP, Peter. 2005. Amnesty: Between an Ethics of Forgiveness and the Politics of Forgetting. In: German Law Journal, 6 (1).

KUHN, Thomas. 2011. A estrutura das revoluções cientificas. São Paulo: Perspectiva.

LAGOMARSINO, David \& WOOD, Charles T. 1989. The Trial of Charles I: a Documentary History. Hanover, N.H.: University Press of New England.

LAMOUNIER, Bolívar. 1987. Raízes do Brasil. In: Revista do Brasil. Número Especial dedicado a Sérgio Buarque de Holanda, ano 3, n. 6.

. 2006. Sérgio Buarque e os "grilhões do passado". In: ARAÚJO, Ricardo Benzaquen de \& SCHWARCZ, Lilia Moritz (orgs.). Raízes do Brasil: edição comemorativa 70 anos. São Paulo: Companhia das Letras.

LIMA, Raquel da C. 2012. A emergência da responsabilidade criminal individual no Sistema Interamericano de Direitos Humanos. In: Lua Nova, 86.

LINZ, Juan J. \& STEPAN, Alfred. 1996. Problems of democratic transition and consolidation: Southern Europe, South America, and Post-Communist Europe. Baltimore: John Hopkins University Press.

LOCHE, Adriana Alves. 2003. Direitos humanos e democracia no Brasil e na Argentina: um estudo de caso. Dissertação de Mestrado. Programa de Pós-Graduação em Integração da América Latina-USP.

LONGMAN, Timothy. 2006. Justice at the Grassroots? Gacaca trials in Rwanda. ROHTARRIAZA, Naomi \& MARIEZCURRENA, Javier (eds.). Transitional Justice in the twenty-first century: beyond truth versus justice. Cambridge USA Press.

LORAUX, Nicole. 1992. Elogio do anacronismo. In: NOVAES, Adauto (org.). Tempo e história. São Paulo: Companhia das Letras.

LUTZ, Ellen. 2006. Transitional Justice: lessons learned and the road ahead. In: ROHTARRIAZA, Naomi \& MARIEZCURRENA, Javier (eds.). Transitional Justice in the twenty-first century: beyond truth versus justice. Cambridge USA Press.

MALARINO, E. 2007. Jurisprudencia latinoamericana sobre derecho penal internacional - um resumen. In: Lateinamerika Analyses, v.18, n.3. 
MAMDANI, Mahmood. 2007. Amnesty or Impunity? A Preliminary Critique of the Report of the Truth and Reconciliation Commission of South Africa. In: BENHABIB, Seyla; SHAPIRO, Ian; PETRANOVICH, Danilo (eds.). Identities, Affiliations, and Allegiances. Cambridge; New York: Cambridge University Press. MAQUIAVEL, Nicolau. 2005. O príncipe. São Paulo: Centauro. . 2007. Discursos sobre a primeira década de Tito Lívio. São Paulo: Martins Fontes.

MARAVALL, J. M. \& PRZEWORSKI, A. 2003. Introduction. In: MARAVALL, J. M. \& PRZEWORSKI, A. (eds.). Democracy and the Rule of Law. Cambridge University Press.

MARAVALL, J. M. \& SANTAMARIA, J. 1991. Political Change in Spain and the Prospects for Democracy. In: Transitions from Authoritarian Rule: Southern Europe. O’DONNELL et al. (eds.). Baltimore: Johns Hopkins University Press.

McCOY, Alfred. W. 2012. Torture and Impunity: the U.S. Doctrine of Coercitive Interrogation. Madison, Wisconsin: University of Wisconsin Press.

McEVOY, Kieran \& McGREGOR, Lorna. 2008 Transitional Justice from Below: an agenda for research, policy and praxis. In: - (eds.). Transitional Justice from Below: Grassroots Activism and the Struggle for Change. Oxford and Portland, Oregon.

MEZAROBBA, Glenda. 2006. Um acerto de contas com o futuro: a anistia e suas conseqüências: um estudo do caso brasileiro. São Paulo: Associação Editorial humanitas/FAPESP.

. 2007. O preço do esquecimento: as reparações pagas às vítimas do regime militar (uma comparação entre Brasil, Argentina e Chile). Tese de doutorado: Departamento de Ciência Política (USP).

. 2010. O processo de acerto de contas e a lógica do arbítrio. In: SAFATLE, Vladimir \& TELES, Edson (orgs.). O que resta da ditadura: a exceção brasileira. São Paulo: Boitempo.

MILTON, John. 2005. A tenência de reis e magistrados. In: DZELZAINIS, M. (org.). Escritos políticos: John Milton. São Paulo: Martins Fontes.

MONSON, Robert. 1992. The West German Statute of Limitations on Murder: a Political, Legal and Historical Explanation. In: American Journal of Comparative Law, 30.

MORAES, João Quartim de. 1989. O poder constituinte e a força. In: Estudos Avançados, vol. 3, n. 7. São Paulo, set.-dez. 
MORAES. Ismael E. B. 2013. Justiça de Transição e a decisão da Corte Interamericana de Direitos Humanos no caso Gomes Lund e outros vs. Brasil. In: Jus Navegandi, 11 de novembro de 2013.

NEVES, Raphael. 2014. Healing the past or causing more evil? Amnesty and Accountability during transitions. Ph.D. Dissertation defended at the Department of Political Sciences at the New School for Social Research, New York.

O’DONNELL, G. 1987. Reflexões sobre os Estados burocrático-autoritários. São Paulo: Vértice; Rio de Janeiro: Revista dos Tribunais.

O’DONNELL, G.; SCHMITTER, P.; WHITEHEAD, L. 1986. Transitions from Authoritarian rule: Latin America. Baltimore, Maryland: John Hopkins University Press.

OLSEN, Tricia; PAYNE, Leigh; REITER, Andrew. 2010. Transitional Justice in balance: comparing processes, weighing efficacy. Washington: United States Institute of Peace.

ORENTLICHER, Daiane. 2004. Whose Justice? Reconciling Universal Jurisdiction with Democratic Principles. In: Georgetown Law Journal, 92 (6): 1057-1134.

. 2007. 'Settling Accounts' Revisited: Reconciling Global Norms with Local Agency. In: International Journal of Transitional Justice, 1 (1).

PALERMO, Vicente. 2000. Como se governa o Brasil? O debate sobre instituições políticas e gestão de governo. In: Dados, 43 (3). Rio de Janeiro.

PAYNE, Thomas. 1974. Regicide and Revolution: Speeches at the Trial of Louis XVI. New York: Cambridge University Press.

PELUSO. Cezar. 2013. Ministro magistrado: decisões de Cezar Peluso no Supremo Tribunal Federal. São Paulo: Saraiva.

PEREIRA, Anthony W. 2005. Political (in)justice: authoritarianism and the Rule of Law in Brazil, Chile and Argentina. University of Pittsburgh Press.

PIOVESAN, Flávia \& PRADO, Inês V. S. (orgs.). 2014. Direitos Humanos atual. Rio de Janeiro: Elsevier.

PIOVESAN, Flávia. 2007. Direitos Humanos e o Direito Constitucional Internacional. São Paulo, Saraiva.

. 2010. Direito internacional dos direitos humanos e lei de anistia: o caso brasileiro. In: SAFATLE, Vladimir \& TELES, Edson (orgs.). O que resta da ditadura: a exceção brasileira. São Paulo: Boitempo. 
2014. Direito à verdade e à justiça: o caso brasileiro. In: PIOVESAN, Flávia \& PRADO, Inês V. S. (orgs.) Direitos Humanos atual. Rio de Janeiro: Elsevier.

POCOCK, John. G. A. 2003. Linguagens do ideário político. São Paulo: EDUSP.

POSNER, Eric; VERMEULE, Adrian. 2003. Transitional justice as ordinary justice. In:

Public Law and Legal Theory Working Paper, n. 40. University of Chicago, mar. 2003. Disponível em: <http://www.law.uchicago.edu/files/files/40.eapav.transitional.both_pdf>. Último acesso em: 29 out. 2014.

QUINALHA, Renan H. 2012. Justiça de Transição: contornos do conceito. São Paulo: Expressão Popular.

RAWLS, Johns. 1971. A Theory of Justice. Cambridge, MA: Harvard University Press.

REIS FILHO, Daniel Aarão. 1990. A revolução faltou ao encontro. São Paulo, Brasiliense.

. 2000. Estranha figura da anistia recíproca. In: REIS, Daniel Aarão. Ditadura militar, esquerdas e sociedade. Rio de Janeiro: Jorge Zahar.

RIDENTI, Marcelo. 1993. O fantasma da revolução brasileira. São Paulo: Ed. UNESP. . 2000. Em busca do povo brasileiro: artistas da revolução, do CPC à era da TV. Rio de Janeiro: Record.

. 2010. Brasilidade revolucionária: um século de cultura e política. São Paulo: Ed. UNESP.

ROHT-ARRIAZA, Naomi \& MARIEZCURRENA, Javier (eds.). 2006. Transitional Justice in the twenty-first century: beyond truth versus justice. Cambridge USA Press.

ROHT-ARRIAZA, Naomi \& POPKIN, Margaret. 1995. Truth as Justice: investigatory Commissions in Latin America. In: Law and Social Inquiry, 20 (Winter 1995).

ROHT-ARRIAZA, Naomi \& SIKKINK, Kathryn. 2001. The Justice Cascade: the Evolution and Impact of Foreign Human Rights Trials in Latin America. In: Chicago Journal of International Law, 2.

ROHT-ARRIAZA, Naomi, \& GIBSON, Lauren. 1998. The Developing Jurisprudence on Amnesty. In: Human Rights Quarterly, 20 (4).

ROHT-ARRIAZA, Naomi. 2005. The Pinochet Effect: Transnational Justice in the Age of Human Rights. University of Pennsylvania Press.

. 2006. The landscape of Transitional Justice. In: ROHT-ARRIAZA, Naomi \& MARIEZCURRENA, Javier (eds.). Transitional Justice in the twenty-first century: beyond truth versus justice. Cambridge USA Press. 
RONIGER, Luis. 2011. Transitional Justice and protracted accountability in Redemocratised Uruguay, 1985-2011. In: Journal of Latin American Studies, n. 43.

ROUQUIÉ, Alain. 1992. Extremo Ocidente: introdução à América Latina. São Paulo: EDUSP.

SAFATLE, Vladimir \& TELES, Edson. 2010. Apresentação. In: SAFATLE, Vladimir \& TELES, Edson (orgs.). O que resta da ditadura: a exceção brasileira. São Paulo: Boitempo.

SALLUM JR., Brasílio. 1996. Labirintos: dos generais à Nova República. São Paulo: Hucitec.

SANTOS, W. Guilherme dos. 1986. 1964: anatomia da crise. São Paulo: Vértice.

SCANLON, T. M. 1999. Punishment and the rule of law. In: KOH, Harold; SLYE, Ronald (eds.). Deliberative democracy and human rights. New Haven: Yale University Press.

SCHABAS, William. 2001. An introdution to the International Criminal Court. Cambridge; New York: Cambridge Universitt Press.

. 2006. The Sierra Leone Truth and Reconciliation Commission. In: ROHTARRIAZA, Naomi \& MARIEZCURRENA, Javier (eds.). Transitional Justice in the twenty-first century: beyond truth versus justice. Cambridge USA Press.

SCHELB, Egon. 1946. Crimes against Humanity. In: British Yearbook International, 23, 178.

SCHMITT, Carl. 1995. Amnestie Oder Die Kraft Des Vergessens. In: . Staat, Großraum, Nomos. Arbeiten Aus Den Jahren 1916 Bis 1969. Berlin: Duncker \& Humblot.

SIKKINK, K \& WALLING, C. B. 2006. Argentina's contribution to global trends in transitional justice. In: ROHT-ARRIAZA, Naomi \& MARIEZCURRENA, Javier (eds.). Transitional Justice in the twenty-first century: beyond truth versus justice. Cambridge USA Press. . 2010. O impacto dos processos judiciais de direitos humanos na America Latina. In: Reis, R. R. (org.). Política de direitos humanos. São Paulo: Hucitec.

SIKKINK, K. 2011. The justice cascade: how human rights prosecutions are changing world politics. New York: W. W. Norton \& Co.

SILVA FILHO, J. C. M. da. 2010. A ditadura de Segurança Nacional no Rio Grande do Sul: história e memória. Porto Alegre: Corag. 
SILVA, Virgílio Afonso da. 2013. Deciding without deliberating. In: International Journal of Constitutional Law, v. 11, p. 557-584.

SOUZA, Maria do C. Campello de. 1983. Estado e partidos políticos no Brasil (1930 a 1964). São Paulo: Alfa-Ômega ed..

STEPAN, Alfred C. 1971. The Military in Politics: changing Patterns in Brazil. Princeton: Princeton University.

STONE SWEET, Alec. 2000. Governing with Judges: Constitutional Politics in Europe. Oxford University Press.

STOVER, Eric; MEGALLY, Hanny; MUFTI, Hania. 2006. Bremer's 'Gordian Knot': Transitional Justice and the US occupation of Iraq. In: ROHT-ARRIAZA, Naomi \& MARIEZCURRENA, Javier (eds.). Transitional Justice in the twenty-first century: beyond truth versus justice. Cambridge USA Press.

SWENSSON JR., Lauro Joppert. 2007. Anistia penal: problemas de validade da lei de anistia brasileira (Lei 6.683/79). Curitiba: Juruá.

. 2010. Punição para os crimes da ditadura militar: contornos do conflito. In: DIMOULIS, D.; MARTINS, A.; SWENSSON JR., L. J. (orgs.). Justiça de Transição no Brasil: Direito, responsabilização e verdade. São Paulo: Saraiva; Direito GV.

TAYLOR, Matthew. 2008. Judging policy: Courts and Policy Reform in Democratic Brazil. Stanford: Stanford University Press.

TEITEL, Ruti. 2003. Transitional Justice Genealogy. In: Harvard Human Rights Journal, $\quad$ v. $16 . \quad$ Disponível em: $<$ http://www.law.harvard.edu/students/orgs/hrj/iss16/teitel.pdf $>$. Último acesso em: 29 de out., 2014. . 2000. Transitional Justice. Oxford University Press: Oxford / New York.

TELES, Edson. 2007. Brasil e África do Sul: os paradoxos da democracia. Memória política em democracias com herança autoritária. Tese de doutorado: Departamento de Filosofia (USP).

TELES, Janaína de Almeida. 2005. Os herdeiros da memória: a luta dos familiares de mortos e desaparecidos políticos por verdade e justiça no Brasil. Dissertação de mestrado: Departamento de História Social (USP).

TORELLY, Marcelo. 2012. Justiça de Transição e Estado Constitucional de Direito: perspectiva teórico-comparativa e análise do caso brasileiro. Belo Horizonte: Fórum. 
TUTU, Desmond. 2000. No future without forgiveness. New York: Doubleday cop.

VENTURA, Deisy. 2011. A interpretação judicial da Lei de Anistia brasileira e o Direito Internacional. In: A Anistia na Era da Responsabilização: o Brasil em perspectiva internacional e comparada. Brasília: Ministério da Justiça, Comissão de Anistia; Oxford: Oxford University, Latin American Centre.

VITUllo, G. E. 2005. Além da transitologia e da consolidologia: um estudo da democracia argentina realmente existente. Tese (Doutorado em Ciência Política). Porto Alegre: Universidade Federal do Rio Grande do Sul.

WAIZBORT, Leopoldo. 2011. O mal-entendido da democracia: Sérgio Buarque de Hollanda, Raízes do Brasil, 1936. In: Revista Brasileira de Ciências Sociais, vol. 26, n. 76, jun. 2011.

WALKER, Margaret U. 2006. Resentment and Assurance. In: Moral Repair: Reconstructing Moral Relations after Wrongdoing. Cambridge: Cambridge University Press.

WALZER, Michael (ed.). 1974. Regicide and Revolution: Speeches at the Trial of Louis XVI. Trans. Marian Tothstein. New York: Cambridge University Press.

WEFFORT, Francisco C. 1978. O populismo na política brasileira. São Paulo: Paz e Terra.

WEICHERT, M. A. 2014. A obrigação constitucional de punir graves violações aos direitos humanos. In: PIOVESAN, Flávia \& PRADO, Inês V. S. (orgs.) Direitos Humanos atual. Rio de Janeiro: Elsevier.

WESCHLER, Lawrence. 1990. A Miracle, A Universe: settling accounts with torturers. New York: Penguin.

WILSON, Richard. 2001. The Politics of Truth and Reconciliation in South Africa. Cambridge: Cambridge University Press.

WINKLER. Heinrich August. 2002. Der lange Weg nach Westen. München: Beck. 


\section{DOCUMENTOS $^{1}$}

\section{Comissão Especial sobre Mortos e Desaparecidos Políticos $(C E M D P)$}

CARNEIRO, A. \& CIOCCARI, M. 2011. Retrato da repressão política no campo (Brasil, 1962-1985): camponeses torturados, mortos e desaparecidos. Brasília: Ministério do Desenvolvimento Agrário.

COMISSÃO ESPECIAL SOBRE MORTOS E DESAPARECIDOS POLÍTICOS. 2007. Direito à memória e à verdade: Comissão Especial sobre Mortos e Desaparecidos Políticos. Brasília: Secretaria Especial dos Direitos Humanos.

VANNUCHI, P. \& BARBOSA, M. A. R. 2007. Apresentação. In: CEMDP. Direito à memória e à verdade: Comissão Especial sobre Mortos e Desaparecidos Políticos. Brasília: Secretaria Especial dos Direitos Humanos.

VANNUCHI, P. \& CASSEL, G. 2011. Apresentação à $1^{\text {a }}$ Edição. In: CARNEIRO, A. \& CIOCCARI, M. Retrato da repressão política no campo (Brasil, 1962-1985): camponeses torturados, mortos e desaparecidos. Brasília: Ministério do Desenvolvimento Agrário.

\section{Comissão Nacional de Anistia}

ABRÃO, Paulo. 2013. Os votos da Comissão de Anistia: da reparação à memória e verdade. In: COELHO, M. J. H. \& ROTTA, V (orgs.). Livro dos Votos da Comissão de Anistia: verdade e reparação aos perseguidos políticos no Brasil. Brasília e Florianópolis: Comunicação, Estudos e Consultoria.

COELHO, M. J. H. \& ROTTA, V (orgs.). 2012. Caravanas da Anistia: o Brasil pede perdão. Brasília: Ministério da Justiça; Florianópolis: Comunicação, Estudos e Consultoria.

. 2013. Livro dos Votos da Comissão de Anistia: verdade e reparação aos perseguidos políticos no Brasil. Brasília e Florianópolis: Comunicação, Estudos e Consultoria.

\footnotetext{
${ }^{1}$ Documentos citados na tese, entre justificativas de projetos de lei, pareceres, relatórios, notas públicas, votos em julgamentos, cartas etc, exceto a legislação nacional e internacional, a qual, por ser demasiado ampla, tem sua referência apenas no corpo da tese.
} 
COMISSÃO NACIONAL DE ANISTIA E INSTITUTO PAULO FREIRE (orgs.). 2012. Paulo Freire, anistiado político brasileiro. Brasília: Comissão Nacional de Anistia; São Paulo: Ed. e Livraria Instituto Paulo Freire.

COMISSÃO NACIONAL DE ANISTIA (org.). 2010. Relatório Anual da Comissão de Anistia (2010). Brasília: Ministério da Justiça. Comissão Nacional de Anistia. . 2012. Vala clandestina de Perus: desaparecidos políticos, um capítulo não encerrado da história brasileira. São Paulo: Instituto Macuco.

. 2013. Marcas da Memória: um projeto de memória e reparação coletiva para o Brasil. In: COELHO, M. J. H. \& ROTTA, V (orgs.). Livro dos Votos da Comissão de Anistia: verdade e reparação aos perseguidos políticos no Brasil. Brasília e Florianópolis: Comunicação, Estudos e Consultoria.

MONTENEGRO, A. T.; RODEGHERO, C. S; ARAÚJO, M. P (orgs.). 2012. Marcas da Memória: história oral da Anistia no Brasil. Recife: Ed. Universitária da UFPE.

PEREIRA, I. X. (org.). 2012. Rádio Libertadora: a palavra de Carlos Marighella. Brasília: Ministério da Justiça, Comissão Nacional de Anistia.

\section{Comissão Nacional da Verdade}

ASSESSORIA DE COMUNICAÇÃO DA CNV. 2012. Comissão da Verdade define estratégias de funcionamento e de estruturas. Brasília, 2 jul. 2012. Destaques. Disponível em: http://www.cnv.gov.br/index.php/outros-destaques/72-comissaoda-verdade-define-estrategias-de-funcionamento-e-estrutura. Acesso em: 4 maio 2015.

COMISSÃO NACIONAL DA VERDADE. 2012a. Resolução nº 2, 02 ago. 2012. Diário Oficial. Brasília, 17 set. 2012. Disponível em: http://www.cnv.gov.br/images/pdf/resolucao_02_200812.pdf. Acesso em 12 de maio de 2015.

. 2012b. Resolução $n^{\circ}$ 4, 17 set. 2012. Diário Oficial. Brasília, 2 out. 2012. Disponível em: http://www.cnv.gov.br/images/pdf/resolucao_4_CNV_1709122.pdf. Acesso em: 12 maio 2015.

. 2014a. Quadro parcial das instalações administrativamente afetadas ou que estiveram administrativamente afetadas às Forças Armadas e que foram utilizadas para perpetração de graves violações de direitos humanos. Brasília: CNV. . 2014b. Relatório Preliminar de Pesquisa: caso Rubens Paiva. Brasília: CNV. 
. 2014c. Relatório Preliminar de Pesquisa sobre a "Casa da Morte de Petrópolis”. Brasília: CNV.

. 2014d. Relatório Preliminar de Pesquisa: centros clandestinos de violação de direitos humanos. Brasília: CNV.

. 2014e. Relatório Preliminar de Pesquisa: o caso Juscelino Kubitschek. Brasília: CNV.

. 2014f. Relatório Preliminar de Pesquisa. Caso Rio Centro: terrorismo de Estado contra a população brasileira. Brasília: $\mathrm{CNV}$.

. 2014g. Relatório Preliminar de Pesquisa: caso Stuart Edgard Angel Jones.

Brasília: CNV.

. 2014h. Relatório, vol. 1. Brasília: CNV.

. 2014i. Relatório, vol. 2. Brasília: CNV.

2014j. Relatório, vol. 3. Mortos e Desaparecidos Políticos. Brasília: CNV.

\section{Supremo Tribunal Federal}

BRITTO, Ayres. 2010. Voto do Ministro Ayres Britto no julgamento da ADPF 153. In: STF. Acórdão de Inteiro Teor. Arguição de Descumprimento de Preceito Fundamental 153. Brasil: Supremo Tribunal Federal. Disponível em: http://redir.stf.jus.br/paginadorpub/paginador.jsp?docTP=AC\&docID=612960.

Acesso em 24 de maio de 2015.

GRACIE, Ellen. 2010. Voto da Ministra Ellen Gracie no julgamento da ADPF 153. In: STF. Acórdão de Inteiro Teor. Arguição de Descumprimento de Preceito Fundamental 153. Brasil: Supremo Tribunal Federal. Disponível em: http://redir.stf.jus.br/paginadorpub/paginador.jsp?docTP=AC\&docID=612960.

Acesso em 24 de maio de 2015.

GRAU, Eros. 2010. Voto do Ministro relator Eros Grau no julgamento da ADPF 153. In: STF. Acórdão de Inteiro Teor. Arguição de Descumprimento de Preceito Fundamental 153. Brasil: Supremo Tribunal Federal. Disponível em: http://redir.stf.jus.br/paginadorpub/paginador.jsp?docTP=AC\&docID=612960.

Acesso em 24 de maio de 2015.

LEWANDOWSKI, Ricardo. 2010. Voto do Ministro Ricardo Lewandowski no julgamento da ADPF 153. In: STF. Acórdão de Inteiro Teor. Arguição de Descumprimento de Preceito Fundamental 153. Brasil: Supremo Tribunal Federal. 
Disponível

em:

http://redir.stf.jus.br/paginadorpub/paginador.jsp?docTP=AC\&docID=612960.

Acesso em 24 de maio de 2015.

. 2015. Discurso de Abertura do Ano Judiciário pelo Ministro Ricardo

Lewandowski. Brasília: Conselho Nacional de Justiça e STF. Disponível em: http://www.stf.jus.br/arquivo/cms/noticiaNoticiaStf/anexo/ABERTURA_DO_AN

O_JUDICIARIO_DE_2015.pdf. Acesso em 26 de março de 2015.

LÚCIA, Carmen. 2010. Voto da Ministra Carmen Lúcia no julgamento da ADPF 153. In: STF. Acórdão de Inteiro Teor. Arguição de Descumprimento de Preceito Fundamental 153. Brasil: Supremo Tribunal Federal. Disponível em: http://redir.stf.jus.br/paginadorpub/paginador.jsp?docTP=AC\&docID=612960.

Acesso em 24 de maio de 2015.

MELLO, Celso de. 2010. Voto do Ministro Celso de Mello no julgamento da ADPF 153. In: STF. Acórdão de Inteiro Teor. Arguição de Descumprimento de Preceito Fundamental 153. Brasil: Supremo Tribunal Federal. Disponível em: http://redir.stf.jus.br/paginadorpub/paginador.jsp?docTP=AC\&docID=612960. Acesso em 24 de maio de 2015.

MELlO, Marco Aurélio. 2009. Voto do Ministro relator Marco Aurélio Mello no julgamento da Extradição 974. In: STF. Acórdão de Inteiro Teor. Extradição 974. Brasil: Supremo Tribunal Federal.

. 2010. Voto do Ministro Marco Aurélio Mello no julgamento da ADPF 153. In: STF. Acórdão de Inteiro Teor. Arguição de Descumprimento de Preceito Fundamental 153. Brasil: Supremo Tribunal Federal. Disponível em: http://redir.stf.jus.br/paginadorpub/paginador.jsp?docTP=AC\&docID=612960.

Acesso em 24 de maio de 2015.

MENDES, Gilmar. 2010. Voto do Ministro Gilmar Mendes no julgamento da ADPF 153. In: STF. Acórdão de Inteiro Teor. Arguição de Descumprimento de Preceito Fundamental 153. Brasil: Supremo Tribunal Federal. Disponível em: http://redir.stf.jus.br/paginadorpub/paginador.jsp?docTP=AC\&docID=612960.

Acesso em 24 de maio de 2015.

PELUSO, Cezar. 2010. Voto do Ministro Cezar Peluso no julgamento da ADPF 153. In: STF. Acórdão de Inteiro Teor. Arguição de Descumprimento de Preceito Fundamental 153. Brasil: Supremo Tribunal Federal. Disponível em: 
http://redir.stf.jus.br/paginadorpub/paginador.jsp?docTP=AC\&docID=612960.

Acesso em 24 de maio de 2015.

SUPREMO TRIBUNAL FEDERAL (STF). 2009. Acórdão de Inteiro Teor. Extradição 974. Brasil: STF.

. 2010. Acórdão de Inteiro Teor. Arguição de Descumprimento de Preceito Fundamental 153. Brasil: Supremo Tribunal Federal. Disponível em: http://redir.stf.jus.br/paginadorpub/paginador.jsp?docTP=AC\&docID=612960.

Acesso em 24 de maio de 2015.

ZAVASCKI, Teori. 2014. Decisão monocrática do Ministro Teori Zavascki em Medida

Cautelar na Reclamação n. 18.686. Brasil: STF. Disponível em: http://www.jusbrasil.com.br/diarios/documentos/142705003/medida-cautelar-nareclamacao-n-18686-do-stf. Acesso em 26 de março de 2015.

Ministério Público Federal e Advocacia Geral da União

ADVOCACIA GERAL DA UNIÃO (AGU). 2009. Manifestação da Advocacia Geral da União na ADPF 153. Advocacia Geral da União. Disponível em: file:///Users/Chris/Downloads/integra_da_manifestacao_da_agu\%20(1).pdf. Acesso em: 26 de maio de 2015.

MINISTÉRIO PÚBLICO FEDERAL. 2013. Crimes da ditadura: relatório preliminar de atos de persecução penal desenvolvido pelo MPF acerca de graves violações de direitos humanos cometidas por agentes do Estado durante a ditadura. Brasília: Procuradoria Geral da República. Disponível em: http://noticias.pgr.mpf.mp.br/noticias/noticias-dosite/copy_of_pdfs/Relatorio_Crimes\%20_Ditatura_completo.pdf. Acesso em 26 de março de 2015.

PROCURADORIA GERAL DA REPÚBLICA (PGR). 2013. Parecer do Procurador-Geral da República Rodrigo Janot sobre pedido de prisão preventiva na Extradição 696. Brasília: Procuradoria Geral da República. Disponível em: http://noticias.pgr.mpf.mp.br/noticias/noticias-do-site/copy_of_pdfs/ppe_696.pdf. Acesso em 26 de março de 2015. 


\section{Congresso Nacional e Presidência da República}

CAPIBERIBE, João. 2014. Parecer do Senador Federal João Capiberibe (PSB-AP) ao Projeto de Lei 237/2013. Brasília: Senado Federal. Disponível em: http://legis.senado.leg.br/mateweb/arquivos/mate-pdf/148362.pdf. Acesso em: 26 de março de 2015.

\section{COMISSÃO INTERMINISTERIAL PARA IDENTIFICAÇÃO DE DESAPARECIDOS}

DA GUERRILHA DO ARAGUAIA. 2007. Relatório da Comissão Interministerial. Brasília, 08 de março de 2007.

ERUNDINA, Luiza. 2011. Projeto de Lei 573/2011, de autoria da Deputada Federal Luiza Erundina (PSB-SP). Brasília: Câmara dos Deputados. Disponível em: http://www.camara.gov.br/proposicoesWeb/prop_mostrarintegra;jsessionid=A657 96B001CF78583DCC33E7132B73C1.proposicoesWeb2? codteor $=844188 \&$ filena me=PL+573/2011. Acesso em: 26 de março de 2015.

FIGUEIREDO, General. 1979. Mensagem de encaminhamento do Projeto de Lei de Anistia ao Congresso Nacional. In: CONGRESSO NACIONAL. Mensagem n. 59, de $1979 . \quad$ Disponível em http://docvirt.com/docreader.net/DocReader.aspx?bib=docbnm\&pagfis=64906\&pe $\mathrm{sq}=($ Pasta: Manifestações de Apoio, Categoria Profissional, Pasta 53, p. 13 e seguintes). Último acesso em 24 de maio de 2015.

. 1981. Discursos. Brasília: Secretaria de Imprensa e Divulgação da Presidência da República.

GEISEL, General. 1975. Discursos. Brasília: Assessoria de Imprensa e Relações Públicas da Presidência da República.

NUNES FERREIRA, Aloysio. 2011. Parecer do Senador Aloysio Nunes Ferreira (PSDBSP) sobre o Projeto de Lei 7.376/2010, da Presidência da República. Brasília: Senado Federal. Disponível em: http://legis.senado.leg.br/mateweb/arquivos/matepdf/98119.pdf. Acesso em 04 de maio de 2015.

PAULO, Vitor. 2011. Parecer do Deputado Federal Vitor Paulo (PRB-RJ) ao Projeto de Lei 573/2011. Brasília: Câmara dos Deputados. Disponível em: http://www.camara.gov.br/proposicoesWeb/fichadetramitacao?idProposicao=4933 11. Acesso em: 26 de março de 2015.

PITIMAN, Luiz. 2012. Parecer do Deputado Federal Luiz Pitiman (PMDB-DF) ao Projeto de Lei 573/2011. Brasília: Câmara dos Deputados. Disponível em: 
http://www.camara.gov.br/proposicoesWeb/prop_mostrarintegra;jsessionid=219E E3F3CC28B72732C8898FEF98274E.proposicoesWeb2?codteor=1053194\&filena me=Parecer-CCJC-21-12-2012. Acesso em: 25 de março de 2015.

RODRIGUES, Randolfe. 2013. Projeto de Lei 237/2013, de autoria do Senador Federal Randolfe Rodrigues (PSOL-AP). Brasília: Senado Federal. Disponível em: http://legis.senado.leg.br/mateweb/arquivos/mate-pdf/130383.pdf. Acesso em 26 de março de 2015.

SECRETARIA ESPECIAL DOS DIREITOS HUMANOS DA PRESIDÊNCIA DA REPÚBLICA (SEDH). 2010. Programa Nacional de Direitos Humanos (PNDH3). Brasília: SEDH.

SOTTILli, R.; JOBIM, N.; BARRETO, L. P. T. F.; SILVA, P. B. 2010. Mensagem de encaminhamento do Projeto de Lei 7.376/2010 ao Congresso Nacional. Brasília: Subchefia de Assuntos Parlamentares da Presidência da República. Disponível em: http://www.planalto.gov.br/ccivil_03/projetos/EXPMOTIV/EMI/2010/14\%20\%20SDH\%20MD\%20MJ\%20MP.htm. Acesso em 05 de maio de 2015.

\section{Corte Interamericana de Direitos Humanos (CrIDH)}

CORTE INTERAMERICANA DE DIREITOS HUMANOS. 2001. Caso Barrios Altos vs. Peru. Mérito. Sentença de 14 mar., série C, n.75.

. 2006. Caso Almonacid Arellano y otros vs. Chile. Exceções preliminares, mérito, reparações e custos. Sentença de 26 de set., série C, n. 154. . 2010. Caso Gomes Lund e outros vs. Brasil. Sentença de 24 de novembro de 2010. Costa Rica, San José. Disponível em: http://www.corteidh.or.cr/docs/casos/articulos/seriec_219_por.pdf. Acesso em 26 de março de 2015. . 2014. Resolução da Corte Interamericana de Direitos Humanos de 17 de outubro de 2014. Caso Gomes Lund e outros vs. Brasil: Supervisão de Cumprimento de Sentença. Costa Rica, San José. Disponível em: http://www.corteidh.or.cr/docs/supervisiones/gomes_17_10_14_por.pdf. Último acesso em 26 de março de 2015. 
Organização das Nações Unidas (ONU)

COMISIÓN DE DERECHOS HUMANOS DE LAS NACIONES UNIDAS. 2006.

Promoción y Protección de los Derechos Humanos: estúdio sobre el derecho a la verdad. Naciones Unidas: Consejo Económico y Social. Disponível em: http://pfdc.pgr.mpf.mp.br/temas-de-atuacao/direito-a-memoria-e-a-

verdade/documentos-tecnicos-de-outros-

orgaos/estudo_direito_a_verdade_ONU_09jan2006. Acesso em 12 de maio de 2015.

UNITED NATIONS ECONOMIC AND SOCIAL COUNCIL. 1993. 45th Session. Study Concerning the Right to Restitution, Compensation, and Rehabilitation for Victims of Gross Violations of Human Rights and Fundamental Freedoms: Final Report, june 2nd 1993, U.N. doc. E/CN.4/suh.2/1993/8.

UNITED NATIONS HUMAN RIGHTS COUNCIL. 2009. Resolution Adopted by the Human Rights Council: Right to the Truth, out. 12th 2009, UN Doc. $\mathrm{A} / \mathrm{HRC} / \mathrm{RES} / 12 / 12$.

UNITED NATIONS SECRETARY-GENERAL. 2004. The Rule of Law and Transitional Justice in Conflict and Post-Conflict Societies. Disponível em: http://www.unrol.org/files/2004\%20report.pdf. Último acesso em: 29 out. 2014.

\section{Outros documentos}

ANISTIA INTERNACIONAL. 2014. Nota pública: Relatório final da Comissão Nacional da Verdade dá passo importante para garantir o direito à memória, à verdade e à justiça. Rio de Janeiro, 10 dez. Disponível em: https://anistia.org.br/noticias/notapublica-relatorio-final-da-comissao-nacional-da-verdade-da-passo-importantepara-garantir-o-direito-memoria-verdade-e-justica/. Acesso em: 5 maio 2015.

ARNS, Dom Paulo Evaristo (org.). 1985. Brasil: nunca mais. Rio de Janeiro: Editora Vozes.

CHILEAN NATIONAL COMMISSION ON TRUTH AND RECONCILIATION. 1993. Report of the Chilean National Commission for Truth and Reconciliation, 2 vols. Trans. Phillip E. Berryman. Notre Dame: University of Notre Dame Press. 
COMISIÓN DE VERDAD Y RECONCILIACIÓN (Perú). 2003. Los factores que hicieron posible la violência, tomo VIII, segunda parte. In: . Informe Final. Lima: Comisión de Verdad y Reconciliación.

COMISSÃO DE FAMILIARES DE MORTOS E DESAPARECIDOS POLÍTICOS et al. 2013. Carta de 15 de julho de 2013 aos comissários da Comissão Nacional da Verdade. Disponível em: http://www.brasil247.com/pt/247/brasil/108681/Familiares-criticamComiss\%C3\%A3o-da-Verdade.htm. Acesso em 04 de maio de 2015. COMISSÃO DE FAMILIARES DE MORTOS E DESAPARECIDOS POLÍTICOS; INSTITUTO DE ESTUDO DA VIOLÊNCIA DO ESTADO; GRUPO TORTURA NUNCA MAIS - RJ E PE. 1995. Dossiê dos mortos e desaparecidos políticos a partir de 1964. Pernambuco: Companhia Editora de Pernambuco; Estado de Pernambuco.

CONADEP - NATIONAL COMMISSION ON THE DISAPPEARED. 1986. Nunca Más: Report of the Argentine National Commission on the Disappeared. New York: Farrar, Straus, Giroux.

CONECTAS DIREITOS HUMANOS. 2014. Um passo histórico. São Paulo, 10 dez 2014. Disponível em: http://www.conectas.org/pt/acoes/justica/noticia/26595-um-passohistorico. Acesso em: 5 maio 2015.

GRUPO TORTURA NUNCA MAIS - SP et al. 2012. Sugestões aos trabalhos da Comissão Nacional da Verdade por Comitês, Fóruns e Coletivos participantes do "Encontro da Comissão Nacional da Verdade com Comitês Estaduais da Sociedade Civil”. Brasília, 30 de julho de 2012. Disponível em: http://coletivorj.blogspot.com.br/2012/08/comites-protocolam-demandascomissao.html. Acesso em 04 de maio de 2015.

INSTITUTO DE ESTUDOS DA RELIGIÃO (ISER). 2012. I Relatório Semestral de Acompanhamento da Comissão Nacional da Verdade (maio a novembro de 2012). Rio de Janeiro: ISER.

. 2013a. Um ano de Comissão da Verdade: contribuições críticas para o debate público. $2^{\circ}$ Relatório de Acompanhamento da Comissão Nacional da Verdade (maio de 2012 a maio de 2013). Rio de Janeiro: ISER.

. 2013b. III Relatório de Monitoramento da Comissão Nacional da Verdade. Rio de Janeiro: ISER. 
2014. IV Relatório de Monitoramento da Comissão Nacional da Verdade. Rio de Janeiro: ISER.

. 2015. Comissão Nacional da Verdade: balanços e perspectivas da finalização de seu processo político-institucional. V Relatório de Monitoramento. Rio de Janeiro: ISER.

ORENTLICHER, Daiane. 2005. Report of the Independent Expert to update the set of principles to combat impunity. Addendum. UN Doc. E/CN.4/2005/102/ Add.1, 8 de fevereiro, 2005.

PERTENCE, Sepúlveda. 1979. Parecer do conselheiro Sepúveda Pertence ao Conselho Federal da Ordem dos Advogados do Brasil sobre o Projeto de Lei de Anistia. Brasília: Ordem dos Advogados do Brasil e Senado Federal.

PIMENTEL, General G. R. Sem data. Relatório requentado. Clube Militar. Rio de Janeiro. Disponível em: http://clubemilitar.com.br/pensamento-do-clube-militar-14/. Acesso em: 5 maio 2015.

SERVICIO PAZ Y JUSTICIA (SERPAJ). 1989. Uruguay: nunca más. Informe sobre la Violación a los Derechos Humanos (1972-1985). Montevideo: SERPAJ.

TRUTH AND RECONCILIATION COMMISSION (South Africa). 1998. Institutional Hearing: the Legal Community. In: Truth and Reconciliation Commission of South Africa Report. London: Macmillan Reference Limited.

UNITED STATES SENATE. 2014. Committee Study of the Central Intelligence Agency's Detention and Interrogation Program. Washington D.C., 13 dez. 2014. Disponível em: http://fas.org/irp/congress/2014_rpt/ssci-rdi.pdf. Acesso em: 4 maio 2015.

USTRA, C. A. B. 2014. A verdade sufocada. São Paulo: Ser.

\section{ARTIGOS DE JORNAIS}

"Ação contra acusados do atentado no Riocentro é trancada no TRF-2". Consultor Jurídico. São Paulo, 2 jul. 2014. Disponível em: http://www.conjur.com.br/2014jul-02/acao-acusados-atentado-riocentro-trancada-trf. Acesso em: 26 mar. 2015.

"Comitê Paulista Memória Verdade e Justiça quer Gilson Dipp fora da Comissão da Verdade”. Vi O Mundo. São Paulo, 15 maio 2012. Denúncias. Disponível em: 
http://www.viomundo.com.br/denuncias/comite-gilson-dipp-fora-da-comissao-daverdade-pois-compromete-a-sua-isencao.html. Acesso em: 4 maio 2015.

“Concedida extradição de major argentino envolvido em masacre”. Notícias STF, Brasília, 19 maio 2011. Disponível em:

http://www.stf.jus.br/portal/cms/verNoticiaDetalhe.asp?idConteudo=180020.

Acesso em: 25 mar. 2015.

“Corte IDH e STF ressaltam importância do sistema interamericano de direitos humanos".

Notícias STF, Brasília, 11 nov. 2013. Disponível em: http://www.stf.jus.br/portal/cms/verNoticiaDetalhe.asp?idConteudo=253184.

Acesso em: 26 mar. 2015.

"Familiares não pedem punição". Folha de São Paulo. São Paulo, 29 ago. 1995. Caderno Brasil, p. 8.

"FHC assina anistia a punidos pela ditadura". Paraná Online, Curitiba, 29 ago. 2002.

Disponível em: http://www.parana-online.com.br/canal/vida-e-saude/news/22553/.

Acesso em: 20 de fev. 2015.

"Justiça recebe denúncia contra militares por sequestros na guerrilha do Araguaia". Ministério Publico Federal, Sala de Imprensa. São Paulo, 30 ago. 2012. Notícias. Disponível em: http://www.prsp.mpf.gov.br/sala-de-imprensa/noticias_prsp/30-0812-justica-recebe-denuncia-contra-militar-por-sequestro-na-guerrilha-do-araguaia. Acesso em: 25 arm. 2015.

"Ley de amnistía brasileña puede ser modificada". Correo del Orinoco, caracas, 28 fev.

2013. Disponível em: http://www.correodelorinoco.gob.ve/judicialesseguridad/ley-amnistia-brasilena-puede-ser-modificada/. Acesso em: 26 mar. 2015.

"MPF denuncia coronel Ustra por morte de jornalista na ditadura". Consultor Jurídico.

São Paulo, 22 set. 2014. Disponível em: http://www.conjur.com.br/2014-set22/mpf-denuncia-coronel-ustra-morte-jornalista-ditadura. Acesso em: 26 mar. 2015.

“PNDH 3 é fiel à Constituição, diz Sepúlvida Pertence”. Carta Maior, Porto Alegre, 18 jan. 2010. Caderno Política. Disponível em: http://cartamaior.com.br/?/Editoria/Politica/PNDH-3-e-fiel-a-Constituicao-dizSepulveda-Pertence/4/15254. Acesso em: 25 mar. 2015.

"Sarney adverte que anistia pode prejudicar a abertura". Jornal do Brasil. Brasília, 22 de fev. de 1978. Política e governo, p. 4. Disponível em: 
http://www2.senado.leg.br/bdsf/bitstream/handle/id/442568/PS\%20jan_dez1978\% 20-\%200137.pdf?sequence=1 . Acesso em: 21 fev. 2015.

Assessoria de Comunicação da Comissão Nacional da Verdade. "Comissão da Verdade define estratégias de funcionamento e de estruturas”. Brasília, 2 jul. 2012. Destaques. Disponível em: http://www.cnv.gov.br/index.php/outros-destaques/72comissao-da-verdade-define-estrategias-de-funcionamento-e-estrutura. Acesso em: 4 maio 2015.

DATAFOLHA. " $47 \%$ fram à Avenida Paulista em 15 de março protestar contra a corrupção". São Paulo, 17 mar. 2015. Disponível em: http://datafolha.folha.uol.com.br/opiniaopublica/2015/03/1604284-47-foram-aavenida-paulista-em-15-de-marco-protestar-contra-a-corrupcao.shtml. Acesso em: 24 abr. 2015.

DUARTE, N. "Ex-ministro reconhece falhas em Comissão Nacional da Verdade". G1. São Paulo, 26 jun 2013. Disponível em: http:/g1.globo.com/saopaulo/noticia/2013/06/ex-ministro-reconhece-falhas-em-comissao-nacional-daverdade.html. Acesso em: 4 maio 2015.

EBOLI, E. "Vice-procuradora da República diz que relatório da CNV dará suporte para ação contra torturadores”. O Globo. Rio de Janeiro, 11 dez. 2014. Caderno Brasil. Disponível em: http://oglobo.globo.com/brasil/vice-procuradora-da-republica-dizque-relatorio-da-cnv-dara-suporte-para-acoes-contra-torturadores14806902 bibliografia.doc. Acesso em: 12 maio 2015.

FALCÃO, M. "Lula diz que anistia 'não foi um ato de benevolência'”.Folha Online. São Paulo, 28 ago. 2009. Caderno Poder. Disponível em: http://www1.folha.uol.com.br/poder/2009/08/613582-lula-diz-que-anistia-nao-foium-ato-de-benevolencia.shtml. Acesso em: 20 fev, 2015.

FRANCO, B. "Juiz abre rocesso contra militares acusados de matar Rubens Paiva". Folha de São Paulo. São Paulo, 26 maio 2014. Caderno Poder. Disponível em: http://www1.folha.uol.com.br/poder/2014/05/1460231-juiz-afasta-anistia-e-abreprocesso-contra-militares-acusados-de-matar-rubens-paiva.shtml. Acesso em: 26 mar. 2015.

HAUBERT, M. "PT defende revisão da Lei de Anistia em programa de governo de Dilma” Folha de São Paulo, São Paulo, 27 maio 2014. Caderno Poder. Disponível em: http://www1.folha.uol.com.br/poder/2014/05/1460621-pt-defende-revisao-dalei-de-anistia-emprograma-de-governo-de-dilma.shtml. Acesso em: 24 fev. 2015. 
IGLESIAS, S.; EBOLI, e.; BRÍGIDO, C. "Cláudio Fonteles deixa Comissão da Verdade por divergências internas". O Globo. Rio de Janeiro, 18 jun. 2013. Cadernos Brasil. Disponível em: http://oglobo.globo.com/brasil/claudio-fonteles-deixacomissao-da-verdade-por-divergencias-internas-8727936. Acesso em: 4 maio 2015.

LUCHETE, F. “TRF-1 mantém ação que acusa coronel Curió de sequestro". Consultor Jurídico. São Paulo, 29 jul. 2014. Disponível em: http://www.conjur.com.br/2014jul-29/trf-mantem-trancada-acao-acusa-coronel-curio-sequestro. Acesso em: 26 mar. 2015.

MELO, J. "Sarney diz que anistia é esquecimento". Blog de Jamildo. Recife, 18 de jan. 2010. Disponível em: http://blogs.ne10.uol.com.br/jamildo/2010/01/18/sarney-dizque-anistia-e-esquecimento/. Acesso em: 21 fev. 2015.

MENDONÇA, R. "Maior parte da população quer anular Lei da Anistia, aponta Datafolha”. Folha de São Paulo. São Paulo, 31 mar. 2014. Caderno Poder. Disponível em: http://www1.folha.uol.com.br/poder/2014/03/1433374-maiorparte-da-populacao-quer-anular-lei-da-anistia-aponta-datafolha.shtml. Acesso em: 11 mar. 2015.

MONTEIRO, T.; DECAT, E.; CARAM, B. "Dilma sinaliza que não é favorável à alteração da Lei da Anistia”. Jornal Estadão, São Paulo, 31 de mar. 2014. Caderno Política. Disponível em: http://politica.estadao.com.br/noticias/geral,dilmasinaliza-que-nao-e-favoravel-a-alteracao-da-lei-da-anistia,1147383. Acesso em: 24 fev. 2015.

MOURA, R.; MONTEIRO, V.; ROSA V. "Comissão da Verdade abre portas à conciliação, diz FHC”. Jornal Estadão, São Paulo, 16 maio 2012. Caderno Política. Disponível em: http://politica.estadao.com.br/noticias/geral,comissao-da-verdadeabre-portas-a-conciliacao-diz-fhc,873765. Acesso em: 24 fev. 2015.

PIVA, J. D. "Coronel revela como sumiu com o corpo de Rubens Paiva”. O Dia Online. Rio de Janeiro, 20 mar. 2014. Caderno Brasil. Disponível em: http://odia.ig.com.br/noticia/brasil/2014-03-20/coronel-revela-como-sumiu-comcorpo-de-rubens-paiva.html. Último acesso: 26 de março de 2015.

PIVA, J. D. "TRF reconhece que Lei de Anistia não abrange crimes contra a humanidade". O Dia Online. Rio de Janeiro, 10 set. 2014. Caderno Brasil. Disponível em: http://odia.ig.com.br/noticia/brasil/2014-09-10/trf-reabre-acao- 
contra-militares-acusados-de-homicidio-de-deputado.html. Acesso em: 26 mar. 2015.

RODRIGUES, A. "Wagner garante que Defesa dará encaminhamento às recomendações da CNV". Agência Brasil. Brasília, 2 jan. 2015. Política. Disponível em: ttp://agenciabrasil.ebc.com.br/politica/noticia/2015-01/wagner-garante-que-defesadara-encaminhamento- recomendacoes-da-cnv. Acesso em: 4 maio 2015.

ROVER, T. "Justiça Federal de São Paulo rejeita nova denúncia contra coronel Ustra". Consultor Jurídico. São Paulo, 20 jan. 2015. Disponível em: http://www.conjur.com.br/2015-jan-20/justica-federal-sp-rejeita-denuncia-coronelustra. Acesso em: 25 mar. 2015.

SARNEY, J. "20 anos de democracia”. Site José Sarney, 10 set. 2011. Disponível em: http://www.josesarney.org/o-escritor/politica/20-anos-de-democracia/. Acesso em: 21 fev. 2015.

SAVERESE, M. "FHC e Lula herdaram capacidade de conciliação de Tancredo, diz professor”. UOL Notícias. São Paulo, 04 mar. 2010. Caderno Política. Disponível em: $\quad$ http://noticias.uol.com.br/politica/ultimas-noticias/2010/03/04/fhc-e-lulaherdaram-capacidade-de-conciliacao-de-tancredo-diz-professor.htm. Acesso em: 20 fev. 2015.

TOMAZELLI, I. "CNV cumpriu papel e seu relatório será analisado, diz comandante da Marinha”. Jornal Estadão. São Paulo, 12 dez. 2014. Caderno Política. Disponível em: http://politica.estadao.com.br/noticias/geral,cnv-cumpriu-papel-e-relatoriosera-analisado-diz-comandante- da-marinha,1606074. Acesso em: 5 maio 2015.

TOSTA, W. "Clube Naval diz que relatório da Comissão da Verdade é 'ilegal'”. Jornal Estadão. São Paulo, 11 dez. 2014. Caderno Política. Disponível em: http://politica.estadao.com.br/noticias/geral,clube-naval-diz-que-relatorio-dacomissao-da-verdade-e-ilegal,1605590. Acesso em: 5 maio 2015.

VENCESLAU, P. "Ex-agente do Dops pede intervenção militar na Paulista". Jornal Estadão. São Paulo, 15 mar. 2015. Caderno Política. Disponível em: http://politica.estadao.com.br/noticias/geral,ex-agente-do-dops-pede-intervencaomilitar-na-paulista,1651268bibliografia.doc. Acesso em: 24 abr. 2015.

VENTURA, D.; QUINALHA, R. "Corte Interamericana em Brasília: uma derrota do provincianismo". Última Instância, 29 nov. 2013. Colunas. Disponível em: http://ultimainstancia.uol.com.br/conteudo/colunas/67780/corte\%20interamericana 
$\% 20 \mathrm{em} \% 20$ brasilia $\% 20$ uma\%20derrota $\% 20$ do\%20provincianismo.shtml. Acesso em: 25 mar. 2015.

WALTZ, I. "Congresso Nacional e movimentos sociais debatem relatório final da CNV". Associação Brasileira de Imprensa. Rio de Janeiro, 12 dez. 2014. Notícias. Disponível em: http://www.abi.org.br/congresso-nacional-e-movimentos-sociaisdebatem-relatorio-final-da-cnv/. Acesso em 21 de abril de 2015.

“Página virada". Folha de São Paulo. São Paulo, 12 dez. 2014. Editorial. Disponível em: http:/www1.folha.uol.com.br/opiniao/2014/12/1561252-editorial-paginavirada.shtml. Acesso em: 12 maio 2015.

“Ampla e irrestrita”. O Globo. Rio de Janeiro, 15 dez. 2014. Editorial. Disponível em: http://oglobo.globo.com/opiniao/ampla-irrestrita-14822807. Acesso em: 12 maio 2015.

“Familiares criticam a Comissão da verdade”. Brasil 247. 16 jul. 2013. Brasil. Disponível em: $\quad$ http://www.brasil247.com/pt/247/brasil/108681/Familiares-criticamComiss\%C3\%A3o-da-Verdade.htm. Acesso em: 4 maio 2015.

\section{ENTREVISTAS REALIZADAS (2013)}

Marcelo Torelly, então coordenador de projetos da Comissão Nacional de Anistia.

Paulo Abrão, presidente da Comissão Nacional de Anistia e Secretário Nacional de Justiça.

Gilmar Mendes, Ministro do Supremo Tribunal Federal.

Maria Amélia Teles, integrante da Comissão de Familiares de Mortos e Desaparecidos Políticos e conselheira da Comissão da Verdade do Estado de São Paulo.

Rosa Maria Cardoso da Cunha, então coordenadora da Comissão Nacional da Verdade.

Adriano Diogo, então deputado estadual (PT) em São Paulo e presidente da Comissão da Verdade do Estado de São Paulo.

Gilberto Natalini, vereador de São Paulo (PV) e então presidente da Comissão da Verdade da Câmara Municipal da cidade. 


\section{FILMES MENCIONADOS}

“Advogados contra a Ditadura: por uma questão de justiça". Direção e produção de Silvio Tendler. Projeto Marcas da Memória/Comissão Nacional de Anistia, 2014. Disponível em: https://www.youtube.com/watch?v=fhRJxeFfbYM. Acesso em 24 de maio de 2015.

"Militares da democracia: os militares que disseram 'não"'. Direção e produção de Silvio Tendler. Projeto Marcas da Memória/Comissão Nacional de Anistia, 2014. Disponível em: https://www.youtube.com/watch?v=fhRJxeFfbYM. Acesso em 24 de maio de 2015. 